ASSESSMENT OF WATER SUPPLY IMPACTS FOR

A MINE SITE IN WESTERN TURKEY

A THESIS SUBMITTED TO

THE GRADUATE SCHOOL OF NATURAL AND APPLIED SCIENCES

$\mathrm{OF}$

MIDDLE EAST TECHNICAL UNIVERSITY

BY

ELİF AĞARTAN

IN PARTIAL FULFILLMENT OF THE REQUIREMENTS

FOR

THE DEGREE OF MASTER OF SCIENCE

IN

GEOLOGICAL ENGINEERING

JUNE 2010 
Approval of the thesis:

\section{ASSESSMENT OF WATER SUPPLY IMPACTS FOR \\ A MINE SITE IN WESTERN TURKEY}

submitted by ELIF A $\breve{G A R T A N ~ i n ~ p a r t i a l ~ f u l f i l l m e n t ~ o f ~ t h e ~ r e q u i r e m e n t s ~ f o r ~ t h e ~}$ degree of Master of Science in Geological Engineering Department, Middle East Technical University by,

Prof. Dr. Canan Özgen

Dean, Graduate School of Natural and Applied Sciences

Prof. Dr. M. Zeki Çamur

Head of Department, Geological Engineering

Prof. Dr. Hasan Yazıcigil

Supervisor, Geological Engineering Dept., METU

\section{Examining Committee Members:}

Prof. Dr. Mehmet Ekmekçi

Hydrogeological Engineering Dept., HÜ

Prof. Dr. Hasan Yazıcıgil

Geological Engineering Dept., METU

Prof. Dr. M. Zeki Çamur

Geological Engineering Dept., METU

Assoc. Prof. Dr. M. Lütfi Süzen

Geological Engineering Dept., METU

Dr. Koray K. Yılmaz

Geological Engineering Dept., METU

Date: $15 / 06 / 2010$ 
I hereby declare that all information in this document has been obtained and presented in accordance with academic rules and ethical conduct. I also declare that, as required by these rules and conduct, I have fully cited and referenced all material and results that are not original to this work.

Name, Last name : Elif AĞARTAN

Signature : 


\title{
ABSTRACT \\ ASSESSMENT OF WATER SUPPLY IMPACTS FOR \\ A MINE SITE IN WESTERN TURKEY
}

\author{
A ğartan, Elif \\ M.S., Department of Geological Engineering \\ Supervisor: Prof. Dr. Hasan Yazıcigil \\ June 2010, 121 pages
}

\begin{abstract}
A certain amount of water is required for a mine site located in Turgutlu in Western Turkey to be used in mining processes. The purpose of this study is to assess the impacts associated with meeting water supply requirements for the mine. Scope of the study involves determination of the alternative water resources, the assessment of impacts associated with each resource and the selection of the most feasible alternative in the aspect of environmental and technical effects.
\end{abstract}

Three alternatives suggested to supply mine process water are surface water, groundwater and reuse of waste water of Turgutlu town after treatment. A low flow analysis of Gediz River was conducted for the evaluation of the surface water. For the groundwater alternative, Turgutlu-Salihli aquifer model was established using MODFLOW 2009.1 software and the impacts on groundwater resources were evaluated. The evaluation of the last alternative, reuse of waste water of Turgutlu after treatment, was based upon the amount of waste water generated and treatment needed.

Results of the alternatives show that each alternative is applicable to supply the required water to the mine site. However, the storage of the Gediz River water in a 
small dam in wet seasons to be used later in dry seasons and the reuse of waste water of Turgutlu after treatment are the alternatives with least impacts on existing water users and related ecosystems.

Keywords: Gediz River, Turgutlu-Salihli aquifer, low flow analysis, numerical modeling, MODFLOW 


\title{
ÖZ
}

\section{TÜRKIYE’NIN BATISINDAKİ BİR MADEN SAHASINA SAĞLANACAK SUYUN ETKİLERINIIN DEĞERLENDİRILMESI}

\author{
Ağartan, Elif \\ Yüksek Lisans, Jeoloji Mühendisliği Bölümü \\ Tez Yöneticisi: Prof. Dr. Hasan Yazıcıgil \\ Haziran 2010, 121 sayfa
}

Türkiye'nin batısında Turgutlu'da yer alan bir maden sahasının belirli bir miktarda suya ihtiyacı vardır. Bu çalışmanın amacı madene sağlanacak suyun etkilerinin değerlendirilmesidir. Çalışma alternatif su kaynaklarının belirlenmesi, her bir kaynağın etkilerinin değerlendirilmesi ile çevresel ve teknik açıdan en uygun alternatifin seçilmesini kapsamaktadır.

Madene su sağlanması için üç alternatif önerilmiştir, bunlar; yüzey suyu, yeraltısuyu ve Turgutlu'nun atık suyunun aritılıp yeniden kullanılmasıdır. Yüzey suyunun değerlendirilmesi amacıyla Gediz Nehri'nin düşük akım analizleri yapılmıştır. Yeraltısuyu alternatifi için Turgutlu-Salihli akiferi Visual MODFLOW 2009.1 programı kullanılarak modellenmiştir ve yeraltısuyu kaynaklarına etkileri değerlendirilmiştir. Son alternatif olan Turgutlu'nun atık suyunun arıtılıp yeniden kullanılmasının değerlendirilmesi de atık su üretim miktarları ve arıtma ihtiyacına dayanmaktadır.

Değerlendirme sonuçlarına göre, madenin su ihtiyacını karşılamak için her alternatif uygulanabilmektedir. Fakat, Gediz Nehri'nin suyunun yağışlı sezonlarda küçük bir barajda kurak sezonlarda kullanılmak üzere saklanması ve Turgutlu'nun atık 
suyunun artılıp yeniden kullanılması alternatiflerinin var olan su kullanımına ve ekosisteme olan etkileri çok azdır.

Anahtar kelimeler: Gediz Nehri, Turgutlu-Salihli akiferi, düşük akım analizi, numerik modelleme, MODFLOW 


\section{TO MY FAMILY,}




\section{ACKNOWLEDGEMENT}

The author would like to express her gratitude to Prof. Dr. Hasan Yazicigil, for his theoretical support, guidance, critism and encouragement throughout all stages of the study.

The author also would like to thank Assoc. Prof. Dr. M. Lütfi Süzen and Assoc. Prof. Dr. Bora Rojay for their help and technical assistance.

Financial support of TÜBİTAK, which gave the author the honor of being a scholar of such an institution devoted to science, is gratefully appreciated.

The author also would like to thank to her mother F. Nesrin Ağartan, her father Ali Suphi Ağartan and her brother Lütfi Ağartan for their patience, love and encouragement during the preparation of this thesis. Sincere thanks are extended to other family members and friends for their support and encouragement whenever needed.

Finally, sincere thanks to Çiğdem Cankara and Burcu Erdemli for their support. 


\section{TABLE OF CONTENTS}

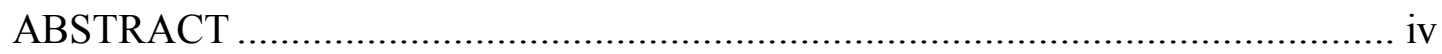

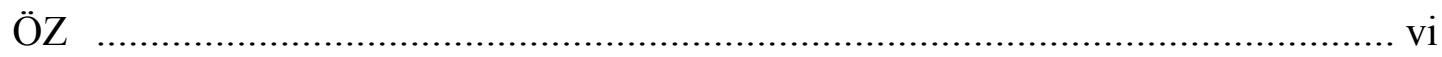

ACKNOWLEDGEMENT …….......................................................... ix

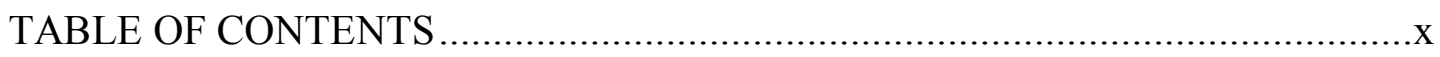

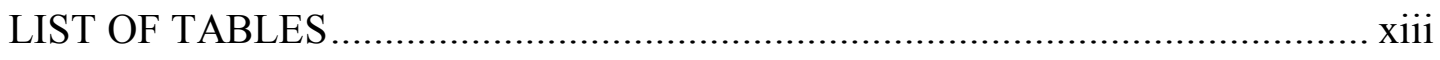

LIST OF FIGURES .................................................................................

CHAPTERS

1 INTRODUCTION ................................................................................. 1

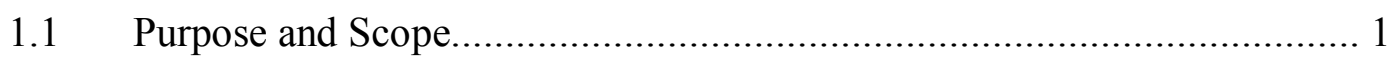

1.2 Location and Extent of the Study Area ............................................... 3

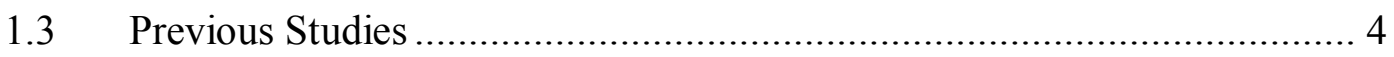

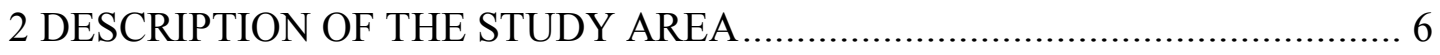

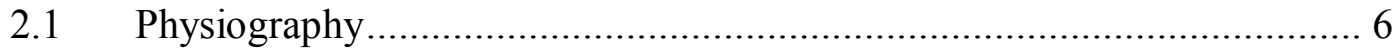

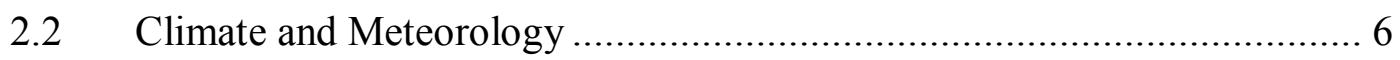

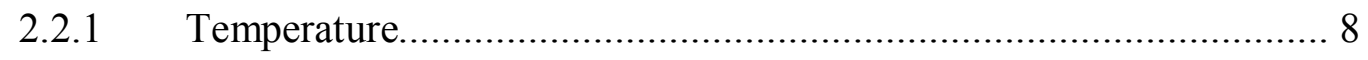

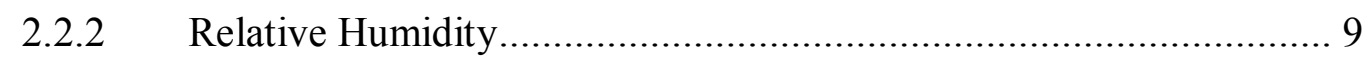

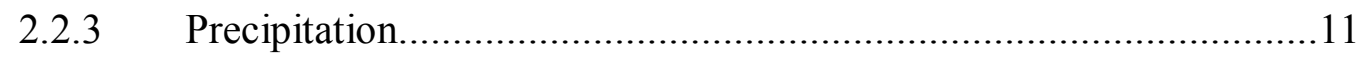

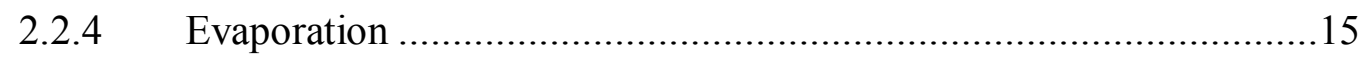

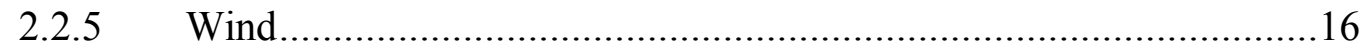

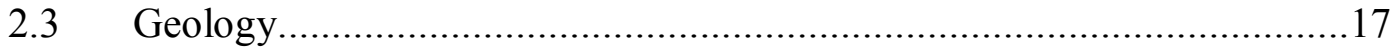

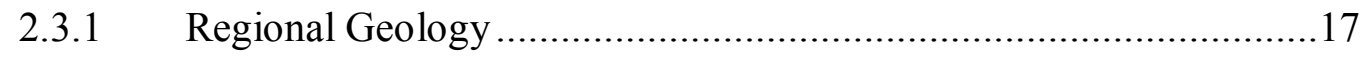

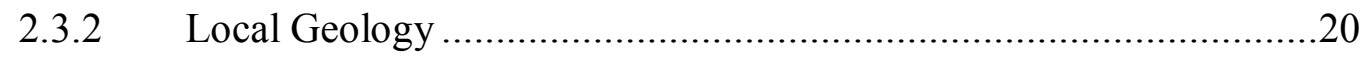

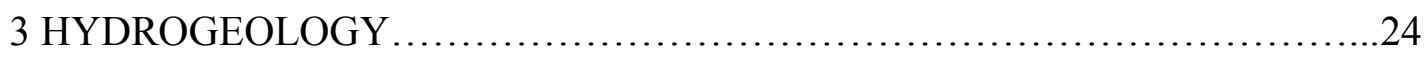

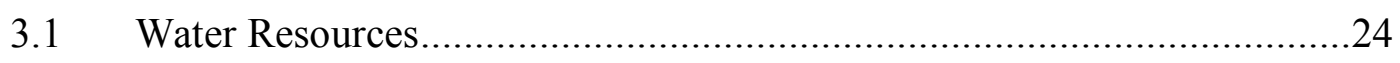

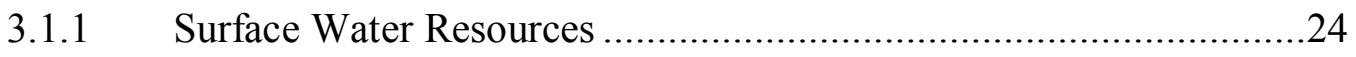

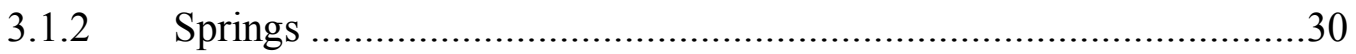

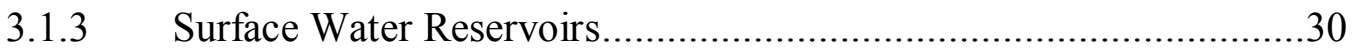


3.1.4 Wells 31

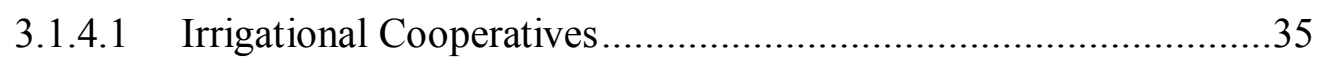

3.2 Characterization of Groundwater Bearing Units....................................37

3.2.1 Hydrogeologic Classification of Groundwater Bearing Units ...........37

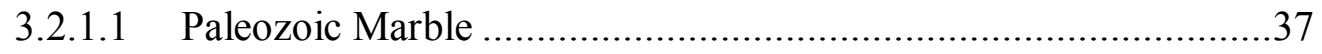

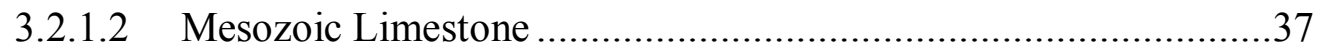

3.2.1.3 Neogene Formations ...............................................................39

3.2.1.4 Quaternary Formations.........................................................39

3.2.2 Hydraulic Properties of Groundwater Bearing Units ......................40

3.2.2.1 Specific Capacity and Well Yield............................................40

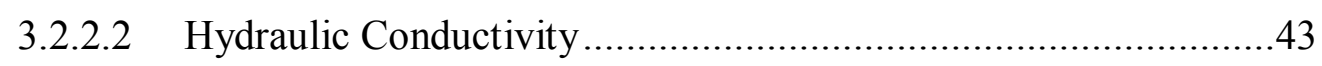

3.2.3 Areal Extent, Depth and Thickness of Groundwater Bearing Units ..43

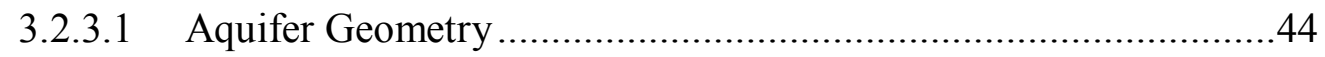

3.2.3.2 Areal Distribution of Groundwater Levels................................49

3.2.3.3 Temporal Changes in Groundwater Levels ...............................49

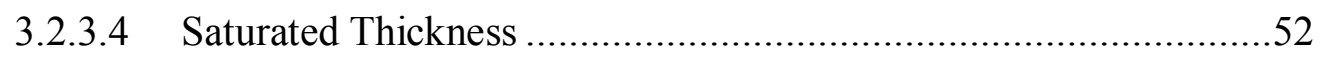

4 ALTERNATIVE SOURCES OF WATER SUPPLY ........................................54

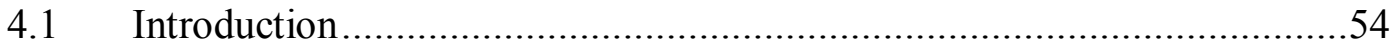

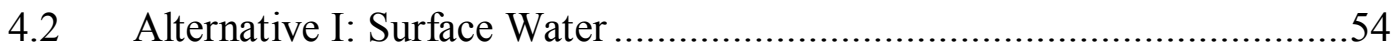

4.2.1 Flow Frequency Histogram and Flow Duration Frequency Curve for

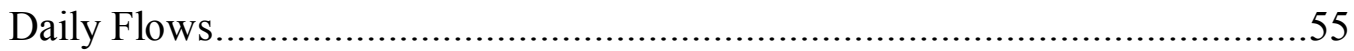

4.2.2 Low Flow Frequency Curves ..................................................57

4.2.3 Low Flow Duration Frequency Curves............................................58

4.2.4 Longest Low Flow Duration Frequency Curve...............................60

4.3 Alternative II: Groundwater..............................................................61

4.3.1 Groundwater Flow Model ............................................................61

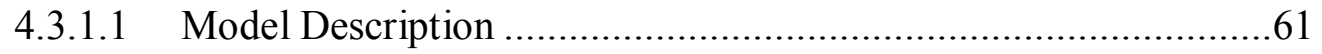

4.3.1.2 Conceptual Model of Aquifer System .........................................62

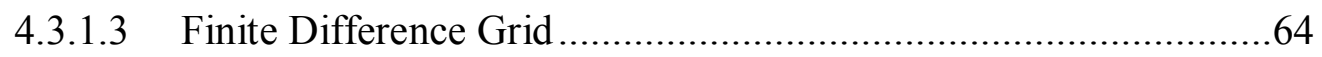

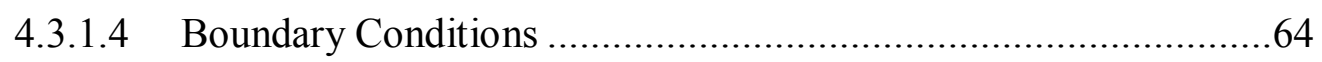

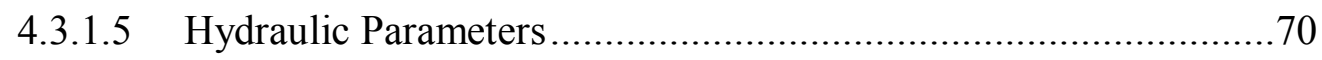




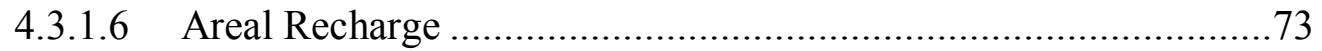

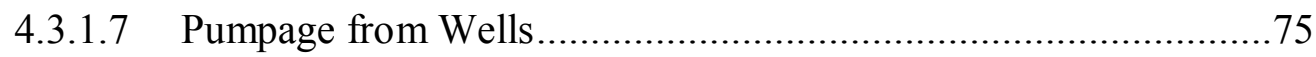

4.3.2 Calibration of the Groundwater Flow Model...................................77

4.3.2.1 Root Mean Square Error (RMS) and RMS Percentage .................78

4.3.2.2 Calculated Groundwater Budget..............................................82

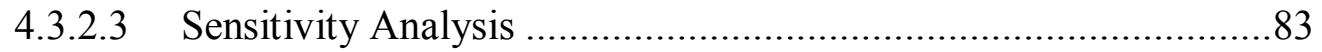

4.3.3 Groundwater Pumping Scenarios ..................................................86

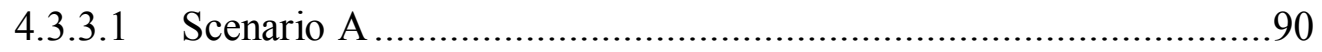

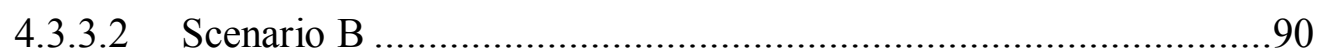

4.4 Alternative III: Reuse of Waste Water of Turgutlu Town after Treatment...

5 DISCUSSION, SUMMARY AND CONCLUSIONS ................................... 100

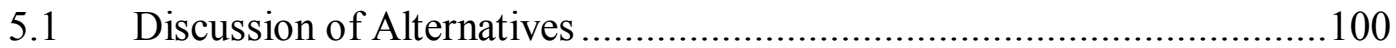

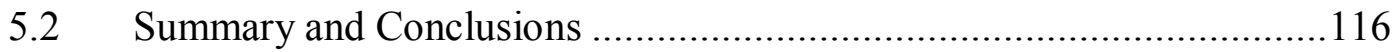

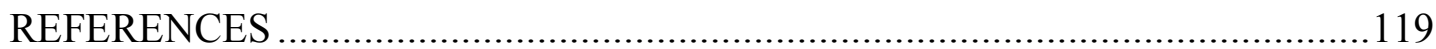




\section{LIST OF TABLES}

\section{TABLES}

Table 2.1: Detailed information about meteorological stations

Table 2.2: The smallest and the largest temperatures and their corresponding times for each station.

Table 2.3: Monthly minimum, average and maximum relative humidity for each station

Table 2.4: Monthly average, minimum and maximum precipitation values for each station

Table 3.1: Information about the flow monitoring stations

Table 3.2: Monthly and annual average flow rates recorded at the flow monitoring

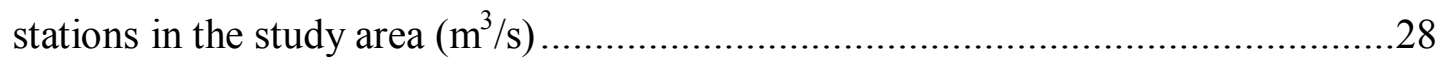

Table 3.3: Purposes of wells.

Table 3.4: Information about wells within the study area. 33

Table 3.5: Yield and specific capacity values of the wells in Quaternary aquifer .....40

Table 3.6: Calculated hydraulic conductivity values of Quaternary aquifer...... .43

Table 3.7: Information about monitoring wells..................................................52

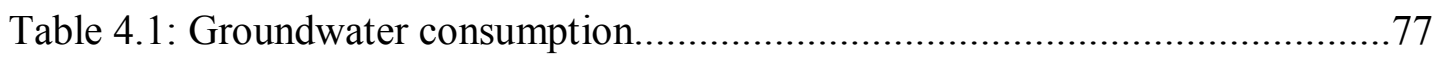

Table 4.2: Groundwater budget of calibrated model for Quaternary aquifer.............83

Table 4.3: Groundwater budget of calibrated model for Neogene aquifer ................83

Table 4.4: Groundwater budget of Quaternary aquifer.........................................89

Table 4.5: Groundwater budget of Neogene aquifer .............................................89

Table 4.6: Wells drilled for domestic purposes...................................................98

Table 4.7: Treatment capacity of Turgutlu Waste Water Treatment Plant ................98

Table 5.1: Calculations of storage of Gediz River water........................113

Table 5.2: Evaluation of all of the alternatives and sub alternatives...............115 


\section{LIST OF FIGURES}

\section{FIGURES}

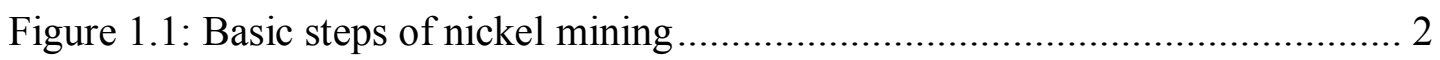

Figure 1.2: Location of the study area .............................................................. 3

Figure 2.1: Locations of meteorological stations in and around the study area......... 7

Figure 2.2: Monthly average relative humidity graph for each station ....................10

Figure 2.3: Monthly average precipitation graph for each station ..........................11

Figure 2.4: Annual precipitation distribution graph for Turgutlu station .................13

Figure 2.5: Annual precipitation distribution graph for Akhisar station ..................13

Figure 2.6: Annual precipitation distribution graph for Manisa station ....................14

Figure 2.7: Annual precipitation distribution graph for Salihli station.....................14

Figure 2.8: Monthly average evaporation graph for Akhisar and Salihli stations......15

Figure 2.9: Monthly average wind speed graph for Akhisar, Manisa and Salihli station 16

Figure 2.10: Geological map of SW Turkey and the study area (Çiftçi \& Bozkurt,

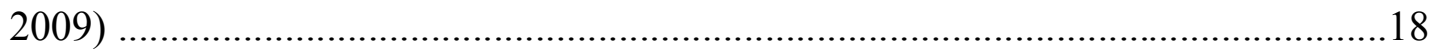

Figure 2.11: Geological map of the study area....................................................22

Figure 2.12: Generalized columnar section of the study area (modified from MTA (1995))

Figure 3.1: Drainage pattern and major surface waters in Gediz River Basin and

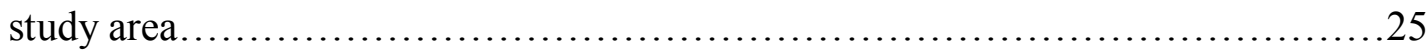

Figure 3.2: Flow monitoring stations in the study area..........................26

Figure 3.3: Annual average flow rates measured at station number $518 \ldots \ldots \ldots \ldots \ldots \ldots . .28$

Figure 3.4: Annual average flow rates measured at station number 533 .................29

Figure 3.5: Monthly average flow rates at station number 518 and 533 ................29

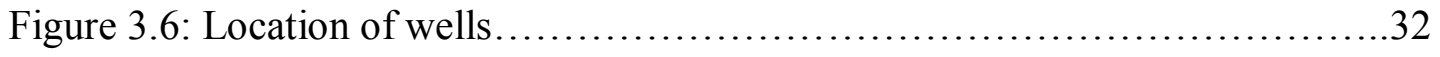

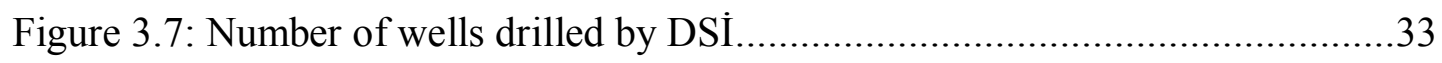

Figure 3.8: Number of wells drilled by Bank of Provinces ....................................34 
Figure 3.9: Total number of wells drilled by Individuals

Figure 3.10: Total number of wells drilled in a year .............................................35

Figure 3.11: Adala Irrigation cooperative wells.................................36

Figure 3.12: Hydrogeological map the study area........................... 38

Figure 3.13: Location of aquifer forming units....................................................45

Figure 3.14: Digital elevation model (DEM) with a grid size of $12.5 \mathrm{~m} . \ldots \ldots \ldots \ldots . . .46$

Figure 3.15: Location of wells and geophysical resistivity points utilized to develop bottom elevation map of Quaternary aquifer. .47

Figure 3.16: Bottom elevation map of Quaternary aquifer.......................48

Figure 3.17: Groundwater elevation map of Quaternary aquifer..................50

Figure 3.18: Location of monitoring wells................................ 51

Figure 3.19: Temporal changes in groundwater levels .......................................52

Figure 3.20: Saturated thickness of the Quaternary aquifer...................................53

Figure 4.1: Daily flow frequency histogram for the Gediz River at Urganlı (No. 533) station

Figure 4.2: Daily flow duration frequency curve for the Gediz River at Urganlı (No. 533) station .56

Figure 4.3: Graphical representation of the definition of low flow volume and low flow discharge (After Salas, 1980)

Figure 4.4: Low flow frequency curves for the Gediz River at Urganlı (No. 533) station .58

Figure 4.5: Graphical representation of the definitions of low flow duration D and longest low flow duration L (After Salas, 1980).

Figure 4.6: Low flow duration frequency curve for the Gediz River at Urganlı (No. 533) Station

Figure 4.7: Longest low flow duration frequency curve for the Gediz River at Urganl1 (No. 533) Station .60

Figure 4.8: N-S oriented cross section showing modeled layers (Typsa, 2007).....66

Figure 4.9: Groundwater flow model finite difference grid.....................................66

Figure 4.10: Units simulated in the groundwater flow model................................67

Figure 4.11: Boundary conditions of Quaternary aquifer.......................................68 
Figure 4.12: Boundary conditions of Neogene aquifer.

Figure 4.13: Hydraulic conductivities of the calibrated model for upper layer..........71

Figure 4.14: Hydraulic conductivities of the calibrated model for lower layer..........72

Figure 4.15: Recharge from precipitation calculated by Thornthwaite method, and the area showing where the extra recharge from surface flow is assigned. 74

Figure 4.16: Wells used for water supply and irrigational purposes.........................76

Figure 4.17: Location of observation wells .79

Figure 4.18: The graphical relation between calculated and observed groundwater levels for both aquifers .80

Figure 4.19: Groundwater elevation map of the calibrated model...........................81

Figure 4.20: Sensitivity analysis for hydraulic conductivity in upper layer ..............84

Figure 4.21: Sensitivity analysis for hydraulic conductivity in lower layer .............84

Figure 4.22: Sensitivity analysis for hydraulic conductivity in both of the layers.....85

Figure 4.23: Sensitivity analysis for recharge .85

Figure 4.24: Groundwater elevation map of the Quaternary aquifer after the addition of wells drilled by DSİ and Bank of Provinces after 1991

Figure 4.25: Groundwater elevation map of the Neogene aquifer after the addition of wells drilled by DSİ and Bank of Provinces after 1991 88

Figure 4.26: Location of scenario wells and the groundwater elevation map of Quaternary aquifer for Scenario A .91

Figure 4.27: Drawdown map of Quaternary aquifer of Scenario A.................92

Figure 4.28: Location of scenario wells and the groundwater elevation map of Quaternary aquifer for Scenario B

Figure 4.29: Location of scenario wells and the groundwater elevation map of Neogene aquifer for Scenario B . .94

Figure 4.30: The drawdown map of Quaternary aquifer for Scenario B .95

Figure 4.31: The drawdown map of Neogene aquifer for Scenario B. .96

Figure 4.32: Location of Turgutlu Waste Water Treatment Plant. . .99

Figure 5.1: Water quality map of the Gediz River and its tributaries...... 101

Figure 5.2: Drawdowns at Quaternary aquifer caused by Scenario A wells 103

Figure 5.3: Drawdowns at Quaternary aquifer caused by Scenario B wells. .104 
Figure 5.4: Drawdowns at Neogene aquifer caused by Scenario B wells 105

Figure 5.5: Drawdown map at lower layer for the sub alternative 1.......................108

Figure 5.6: Drawdown map at upper layer for the sub alternative 2.......................109

Figure 5.7: Drawdown map at upper layer for the sub alternative 3......................110

Figure 5.8: Drawdown map at lower layer for the sub alternative $3 \ldots \ldots \ldots \ldots \ldots 11$ 


\section{CHAPTER 1}

\section{INTRODUCTION}

\subsection{Purpose and Scope}

Water is essential for life on earth. In the ancient times, richness of towns was represented by the number of fountains they owned. The more fountains a town had, the richer it was considered to be. To use water in daily life, ancient people constructed first pipeline systems as aqueducts and sewage systems. With the development of technology, besides everyday usage, people started to use water in other fields, such as in the mining processes. Mines are in everywhere on Earth, and Turkey has a considerable amount of mines. The nickel mine in Çaldağ is one of them, which is currently under planning. Basic steps of nickel mining process are illustrated in Figure 1.1. For Çaldağ nickel deposits, the mining operations will include: three open pits, a leach pad, a waste rock storage area, a limestone quarry and surface process facilities. Operation time of the mining process is 15 years. For 15 years, $135 \mathrm{~L} / \mathrm{s}$ water is required to be used in mining processes.

The purpose of this study is to assess the impacts associated with meeting the water supply requirements for the Çaldağ nickel mine located in Turgutlu in Western Turkey. Nowadays, because of the declining water levels either for surface waters or groundwater, each and every water resource has great significance for humans and ecosystems. In order not to cause a water deficiency, for the processes for which water is prerequisite, except for drinking purposes, alternative water resources are 
offered. Therefore, the scope of this study involves the determination of the alternative water resources, assessment of impacts associated with each resource and selection of the most feasible alternative in the aspect of environmental impacts. Three alternative sources are suggested to supply the mine process water, which are surface water, groundwater and the reuse of waste water of Turgutlu after treatment. A low flow analysis of Gediz River is conducted for evaluation of the surface water. For the groundwater alternative, Turgutlu-Salihli aquifer model is developed and the impacts on groundwater resources are evaluated with the help of this model. The evaluation of the last alternative, reuse of waste water of Turgutlu after treatment is based upon the amount of waste water generated and treatment needed.

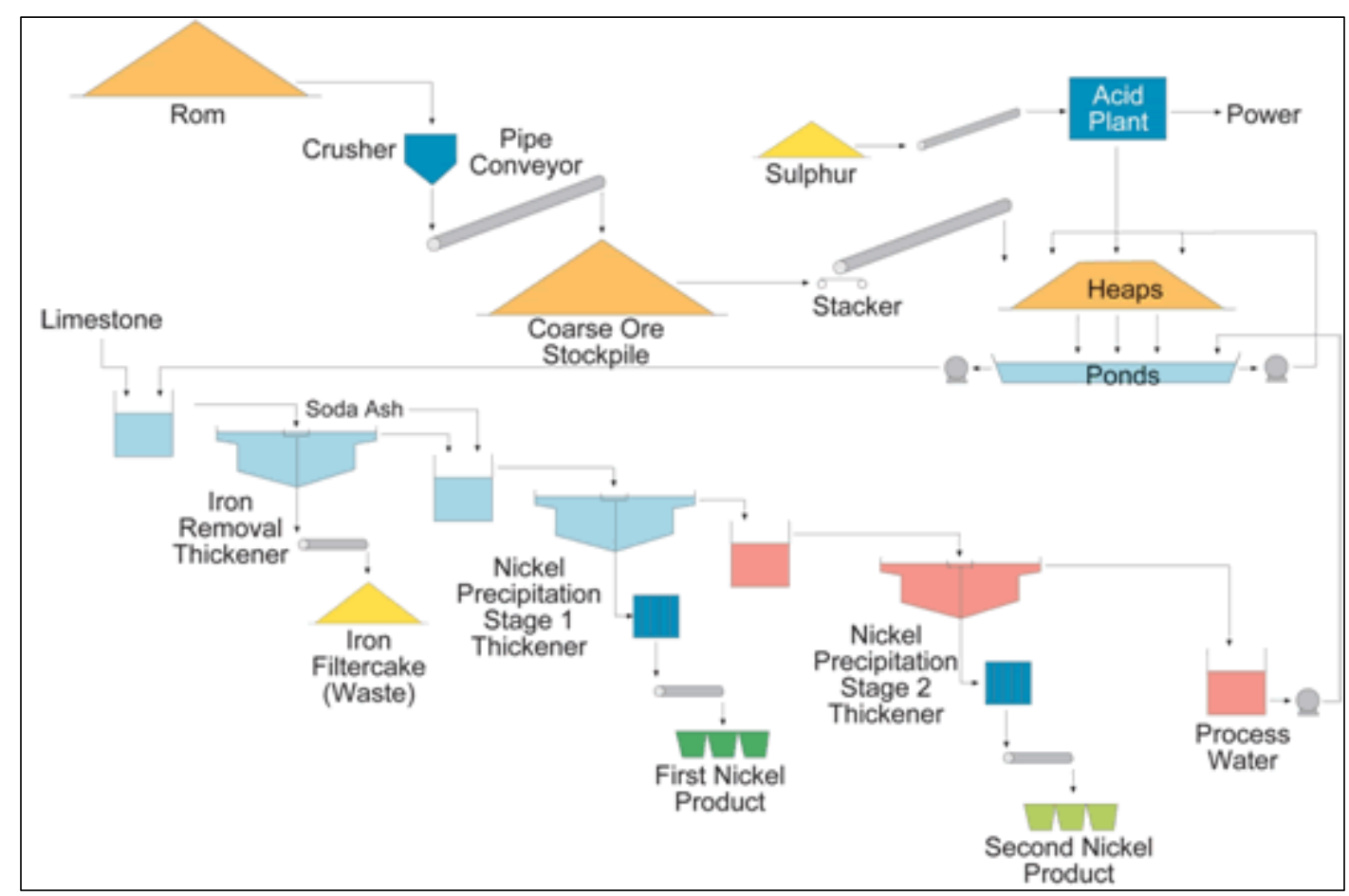

Figure 1.1: Basic steps of nickel mining 


\subsection{Location and Extent of the Study Area}

The study area is located in Gediz River Basin in Western Turkey (Figure 1.2). It is situated within Turgutlu, Ahmetli and Salihli districts of Manisa city. The study area covers $1462 \mathrm{~km}^{2}$ and situated between UTM $4247400-4285000 \mathrm{~N}$ and UTM $543200-620400$ E coordinates.

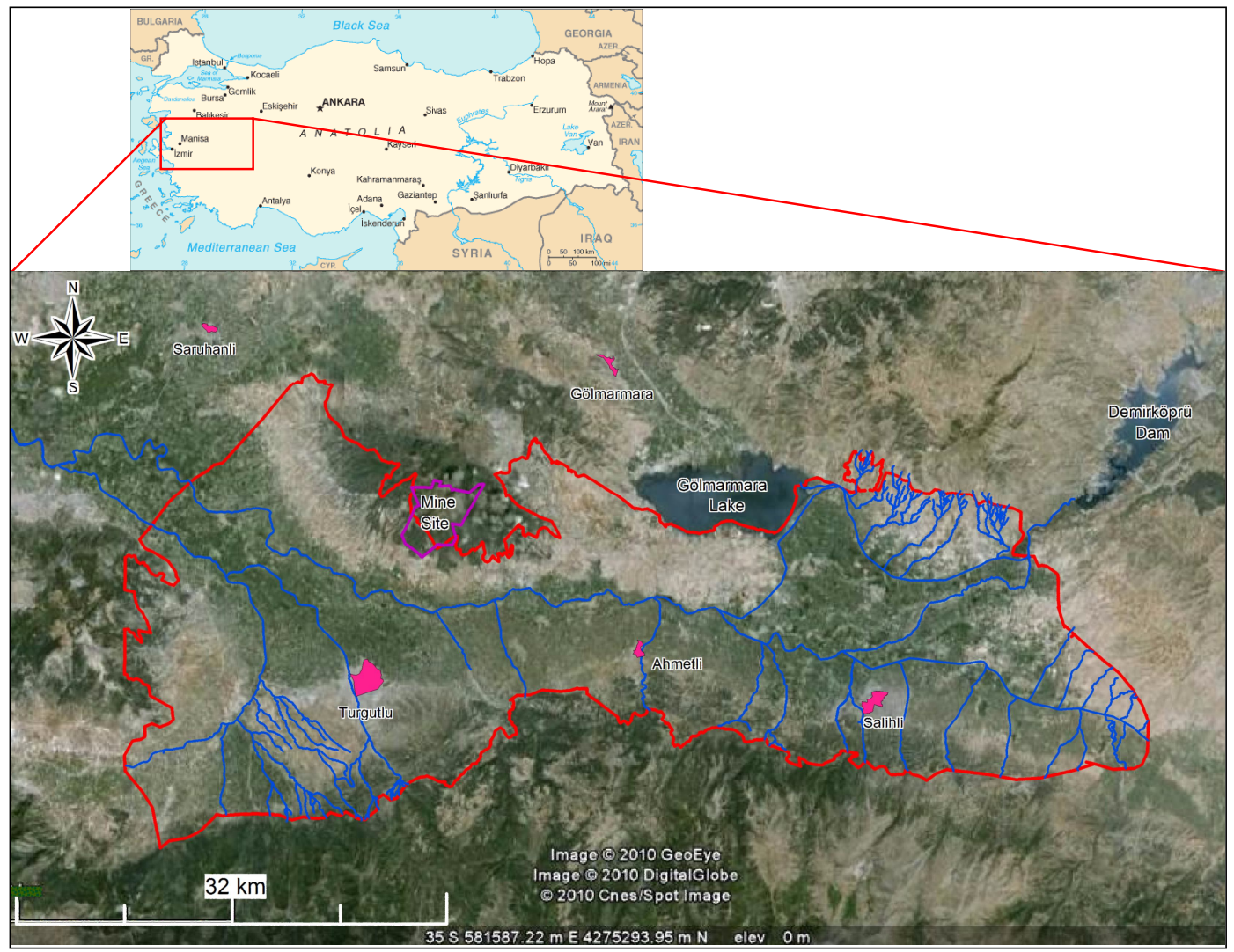

Figure 1.2: Location of the study area 


\subsection{Previous Studies}

Within and around the study area, many geological and geomorphologic studies have been carried out since $20^{\text {th }}$ century. Brief explanation about these studies is given below.

First geological study within and around the study area was carried out by Philippson in 1915. In that study, age of the micaschist, clayey greywacke, gabbro, diabase and limestone units were determined as Paleozoic. Since 1915, there have been numerous studies about geology of the region performed in and around the study area by esteemed scientists. Geological map of scales 1/500,000, 1/100,000 and 1/25,000 including different parts of the study area were prepared by the General Directorate of Mineral Research and Exploration (MTA). Latest studies about geology of the study area were performed by Bozkurt and Satır (2000); Bozkurt and Sözbilir (2004); Çiftçi and Bozkurt (2009); and Selim and Yanık (2009). Moreover, some other studies were carried out to examine mines and geothermal potential of the Gediz River Basin etc. The only geophysical resistivity investigation was performed by DSI in 1973.

First hydrogeological investigation about the study area was the carried out by $2^{\text {nd }}$ District Office of State Hydraulic Works (DSI) in 1983 which is called "The Hydrogeological Investigation Report for Gediz River Basin (Sarı̈öl-Alaşehir, Salihli-Turgutlu and Akhisar-Manisa Plains)". After this study, some other reports were produced by DSI based on the suggestions in the report written in 1983 . Moreover, several hydrogeological studies about Turgutlu and Salihli region were performed by İller Bankas1 (Bank of Provinces) but their main focus is on the localities around the municipalities. In 2005, "The Environmental Impact Assessment Report - Çaldağ Project" was prepared by Turkish Environmental Consulting Company, ENCON. In the report, each part of the Çaldağ nickel mine project is explained in detail. Supplying process water to mine is one of them. It was assumed that $35 \mathrm{~L} / \mathrm{s}$ of the water are supplied from groundwater and the remaining 
from surface water. For the groundwater, five scenarios with different well designs are suggested in the report. The latest study about the hydrogeology was carried out by Yazicigil (2008) and focused on the hydrogeological characterization of the Çaldağ Nickel Mine Project Area. Moreover, the study carried out by Typsa Consulting Engineers and Architects (2007) is about the management of solid waste and waste water, and conservation of the wetlands in Gediz Delta. In 2009, Man-ar Construction and Environmental Technologies Company was performed a study to determine the waste water potential of the Turgutlu town and the possibilities for Turgutlu waste water treatment plant. 


\section{CHAPTER 2}

\section{DESCRIPTION OF THE STUDY AREA}

\subsection{Physiography}

The study area is located in inlands of the Aegean region and encloses the TurgutluSalihli part of the Gediz River (Figure 1.2). The basin is surrounded by Gölmarmara Lake and ridges with altitudes ranging between $500 \mathrm{~m}$ and $1000 \mathrm{~m}$ in the north, by Demirköprü Dam and ridges with altitudes ranging between $200 \mathrm{~m}$ and $400 \mathrm{~m}$ in the east, Menderes Massive Metamorphic Rocks and ridges with altitudes ranging between $400 \mathrm{~m}$ and $610 \mathrm{~m}$ in the south, and finally by Karaoğlanlı district of Manisa and ridges with altitudes ranging between $700 \mathrm{~m}$ and $900 \mathrm{~m}$ in the west.

\subsection{Climate and Meteorology}

The study area has mild climate with soft verdant springs, hot and dry summers, sunny autumns and warm winters marked by occasional showers. Aegean region has many valleys between the mountains perpendicular to the shores due to graben plains in the region. The graben plain permits the marine climate (very similar to Mediterranean climate) reach inner parts of the region although some of the provinces inland show characteristics of Continental climate. 
There are six meteorological stations, namely; Saruhanlı, Gölmarmara, Turgutlu, Akhisar, Manisa and Salihli established by the State Meteorological Organization (DMI) in and around the study area (Figure 2.1 and Table 2.1). Two of them (Turgutlu and Salihli) are located within the study area and four of them are located in close vicinity. Among these stations, Manisa, Akhisar and Salihli are principal climatological stations at which hourly temperature, solar radiation, wind speed and direction, precipitation (three times daily) and maximum precipitation (monthly) observations are made three times a day at fixed hours. Turgutlu station is an ordinary climatological station which measures temperature, wind speed and direction, precipitation (three times daily and daily total). The type of meteorological stations, their coordinates and elevations, as well as period of observations are given in Table 2.1.

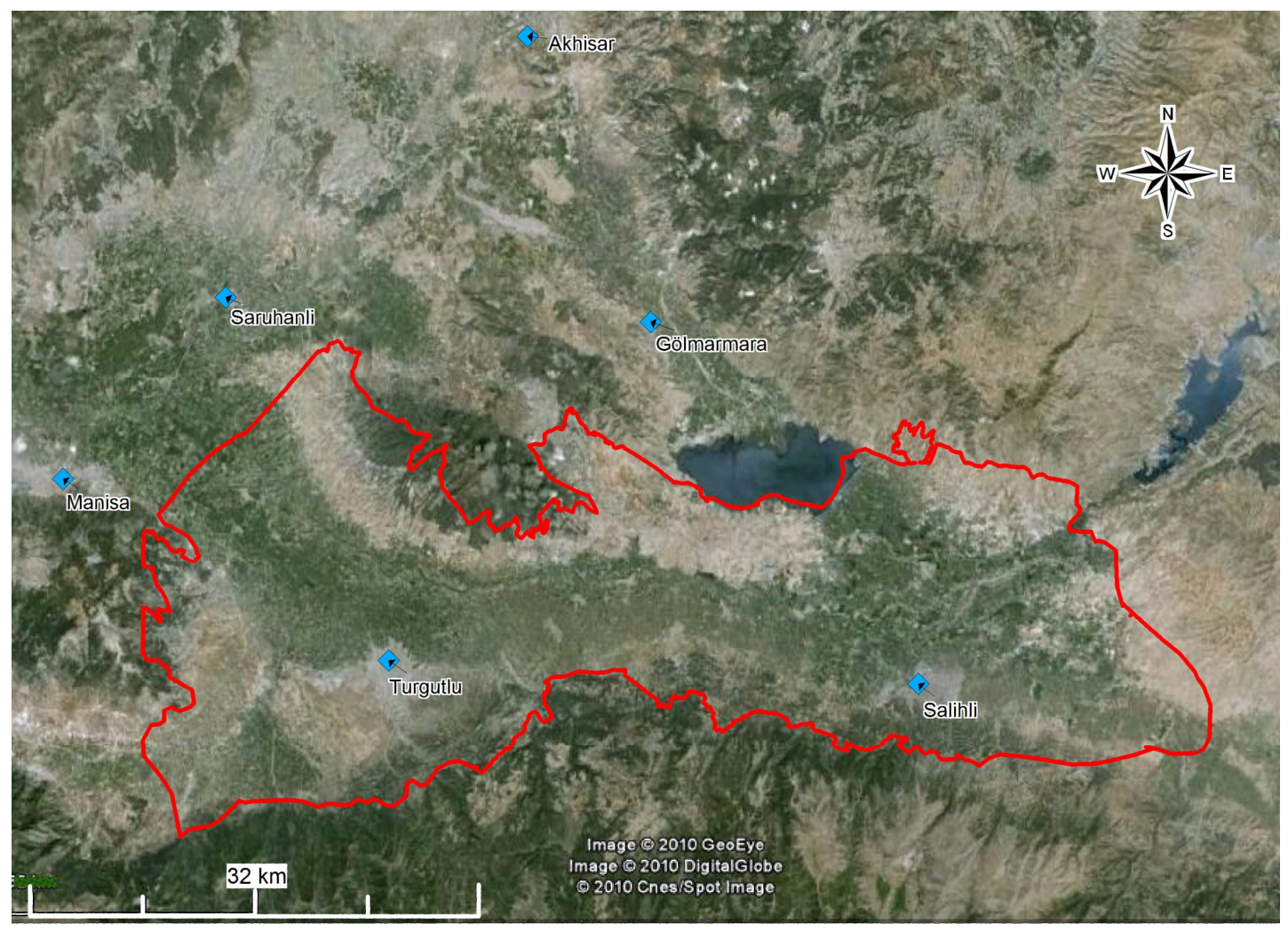

Figure 2.1: Locations of meteorological stations in and around the study area 
Table 2.1: Detailed information about meteorological stations

\begin{tabular}{|c|c|c|c|c|c|c|}
\hline & \multirow{2}{*}{$\begin{array}{c}\text { Station } \\
\text { Number }\end{array}$} & Type of Station & \multicolumn{2}{|c|}{ Coordinates } & $\begin{array}{c}\text { Period of } \\
\text { Data } \\
\text { Availability }\end{array}$ & $\begin{array}{c}\text { Elevation } \\
(\mathrm{m})\end{array}$ \\
\cline { 4 - 6 } Saruhanl1 & 5269 & - & 549301 & 4287516 & $1986-1995$ & 40 \\
\hline Gölmarmara & 5273 & - & 579741 & 4285913 & $1984-1991$ & 103 \\
\hline Turgutlu & 5615 & $\begin{array}{c}\text { Ordinary } \\
\text { Climatological } \\
\text { Station }\end{array}$ & 561087 & 4261704 & $1984-2006$ & 120 \\
\hline Manisar & 17184 & $\begin{array}{c}\text { Synoptic, } \\
\text { Principal } \\
\text { Climatological } \\
\text { and Automatic t2 } \\
\text { Station }\end{array}$ & 570865 & 4306176 & $1937-2006$ & 92 \\
\hline Salihli & 17186 & $\begin{array}{c}\text { Synoptic, } \\
\text { Principal } \\
\text { Climatological } \\
\text { and Automatic t1 } \\
\text { Station }\end{array}$ & 537773 & 4274507 & $1930-2006$ & 71 \\
\hline & $\begin{array}{c}\text { Principal } \\
\text { Climatological } \\
\text { and Automatic t2 } \\
\text { Station }\end{array}$ & 598897 & 4260231 & $1939-2006$ & 111 \\
\hline
\end{tabular}

\subsubsection{Temperature}

The average annual temperature for the study area using the long-term data from the DMI stations was calculated as $16.34{ }^{\circ} \mathrm{C}$. The average monthly minimum and average monthly maximum temperatures as well as the minimum and maximum monthly temperatures observed in the period of record for each station is given in Table 2.2 with the time of occurrence. January and February are the coldest months in the region when the monthly minimum temperatures average to $-4.44^{\circ} \mathrm{C}$. Salihli Meteorological Station is the station at which the lowest monthly temperature was observed in February 2004 as $-13.5^{\circ} \mathrm{C}$. July is the hottest month in the region when the monthly maximum temperatures average to $39.76^{\circ} \mathrm{C}$. The maximum monthly temperature in the region was observed at Manisa Meteorological Station in July 2000 with a value of $45.1^{\circ} \mathrm{C}$. 
Table 2.2: The smallest and the largest temperatures and their corresponding times for each station

\begin{tabular}{|c|c|c|c|c|c|c|c|}
\hline & & \multicolumn{6}{|c|}{ Meteorological Stations } \\
\hline & & Saruhanlı & Gölmarmara & Turgutlu & Akhisar & Manisa & Salihli \\
\hline \multirow{5}{*}{$\begin{array}{l}\text { Minimum } \\
\text { Temperature }\end{array}$} & $\begin{array}{c}\text { Minimum } \\
\text { Monthly } \\
\text { Temperature }\left({ }^{\circ} \mathrm{C}\right)\end{array}$ & -8.2 & -7.8 & -10 & -13.2 & -13.1 & -13.5 \\
\hline & $\begin{array}{c}\text { Month \& Year of } \\
\text { Observation }\end{array}$ & $\begin{array}{c}\text { Feb } \\
1992\end{array}$ & $\begin{array}{l}\text { Feb } \\
1985\end{array}$ & $\begin{array}{c}\text { Feb } \\
2004\end{array}$ & $\begin{array}{c}\text { Jan } \\
1954\end{array}$ & $\begin{array}{c}\text { Jan } \\
1954\end{array}$ & $\begin{array}{c}\text { Feb } \\
2004\end{array}$ \\
\hline & & & & & & & \\
\hline & $\begin{array}{c}\text { Min.of the } \\
\text { Average Monthly } \\
\text { Temperature }\left({ }^{\circ} \mathrm{C}\right)\end{array}$ & -5.13 & -4.06 & -3.81 & -5.25 & -4 & -4.4 \\
\hline & $\begin{array}{c}\text { Month of } \\
\text { Observation }\end{array}$ & February & February & January & January & January & January \\
\hline $\begin{array}{c}\text { Average } \\
\text { Temperature }\end{array}$ & $\begin{array}{c}\text { Average } \\
\text { Temperature }\left({ }^{\circ} \mathrm{C}\right)\end{array}$ & 15.9 & 16.3 & 16.7 & 16.1 & 16.9 & 16.3 \\
\hline & & & & & & & \\
\hline \multirow{5}{*}{$\begin{array}{l}\text { Maximum } \\
\text { Temperature }\end{array}$} & $\begin{array}{c}\text { Maximum } \\
\text { Monthly } \\
\text { Temperature }\left({ }^{\circ} \mathrm{C}\right)\end{array}$ & 42 & 43.2 & 44.9 & 44.6 & 45.1 & 44.8 \\
\hline & $\begin{array}{c}\text { Month \& Year of } \\
\text { Observation }\end{array}$ & $\begin{array}{c}\text { Jul } \\
1987 \\
\end{array}$ & $\begin{array}{c}\text { Jul } \\
1987 \\
\end{array}$ & $\begin{array}{c}\text { Jul } \\
2000 \\
\end{array}$ & $\begin{array}{l}\text { Aug } \\
1958 \\
\end{array}$ & $\begin{array}{c}\text { Jul } \\
2000 \\
\end{array}$ & $\begin{array}{c}\text { Jul } \\
2000 \\
\end{array}$ \\
\hline & & & & & & & \\
\hline & $\begin{array}{l}\text { Max.of the } \\
\text { Average Monthly } \\
\text { Temperature }\left({ }^{\circ} \mathrm{C}\right)\end{array}$ & 39.76 & 39.6 & 39.93 & 39.83 & 40.02 & 39.42 \\
\hline & $\begin{array}{c}\text { Month of } \\
\text { Observation }\end{array}$ & July & July & July & July & July & July \\
\hline
\end{tabular}

\subsubsection{Relative Humidity}

The monthly average values of relative humidity for each DMİ meteorological stations are given in Figure 2.2. The average relative humidity for all DMİ stations varies from $46 \%$ in June and July to $75 \%$ in December (Table 2.3). The annual average relative humidity was calculated as $60 \%$. The lowest relative humidity is observed in Gölmarmara station, whereas Akhisar has the highest relative humidity values. 


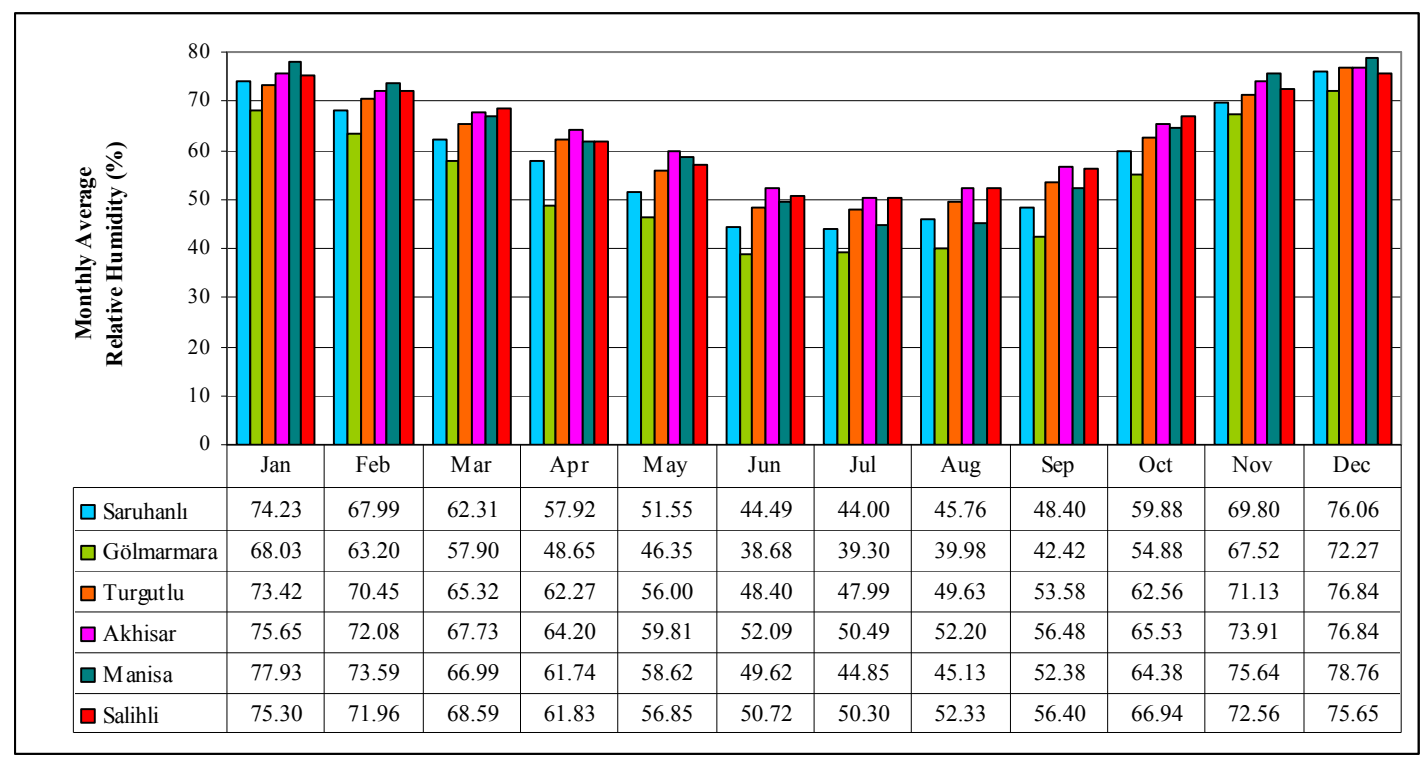

Figure 2.2: Monthly average relative humidity graph for each station

Table 2.3: Monthly minimum, average and maximum relative humidity for each station

\begin{tabular}{|c|c|c|c|c|c|c|}
\hline & Saruhanlı & Gölmarmara & Turgutlu & Akhisar & Manisa & Salihli \\
\hline $\begin{array}{l}\text { Monthly Min. Relative } \\
\text { Humidity (\%) }\end{array}$ & 36.8 & 34.1 & 33 & 37.8 & 35.5 & 39.8 \\
\hline $\begin{array}{c}\text { Month \& Year of } \\
\text { Observation }\end{array}$ & Jul.94 & Jul. 85 & Jun.01 & Jun.03 & Jul.45 & Jun.01 \\
\hline $\begin{array}{l}\text { Min.of the Monthly Avg. } \\
\text { Relative Humidity (\%) }\end{array}$ & 44 & 38.46 & 47.99 & 50.49 & 44.85 & 50.22 \\
\hline Month of Observation & Jul & Jun & Jul & Jul & Jul & Jun \\
\hline $\begin{array}{c}\text { Average Relative } \\
\text { Humidity }(\%)\end{array}$ & 58.5 & 53.4 & 61.5 & 63.9 & 60.9 & 62.7 \\
\hline $\begin{array}{c}\text { Monthly Max. Relative } \\
\text { Humidity (\%) }\end{array}$ & 83.2 & 76.2 & 82.5 & 86.3 & 88.2 & 86.3 \\
\hline $\begin{array}{l}\text { Month \& Year of } \\
\text { Observation }\end{array}$ & Dec.90 & Dec. 85 & Dec.04 & Dec. 50 & Dec. 50 & Jan. 82 \\
\hline $\begin{array}{l}\text { Max.of the Monthly Avg. } \\
\text { Relative Humidity (\%) }\end{array}$ & 76.06 & 71.7 & 76.84 & 76.84 & 78.76 & 75.17 \\
\hline Month of Observation & Dec & Dec & Dec & Dec & Dec & Dec \\
\hline
\end{tabular}




\subsubsection{Precipitation}

The distribution of monthly average precipitation for each station is shown in Figure 2.3. The maximum and the minimum monthly average precipitation with their corresponding times and the average annual precipitation values are summarized in

Table 2.4. December is the wettest month for each station, and except for Gölmarmara station, August is the driest month.

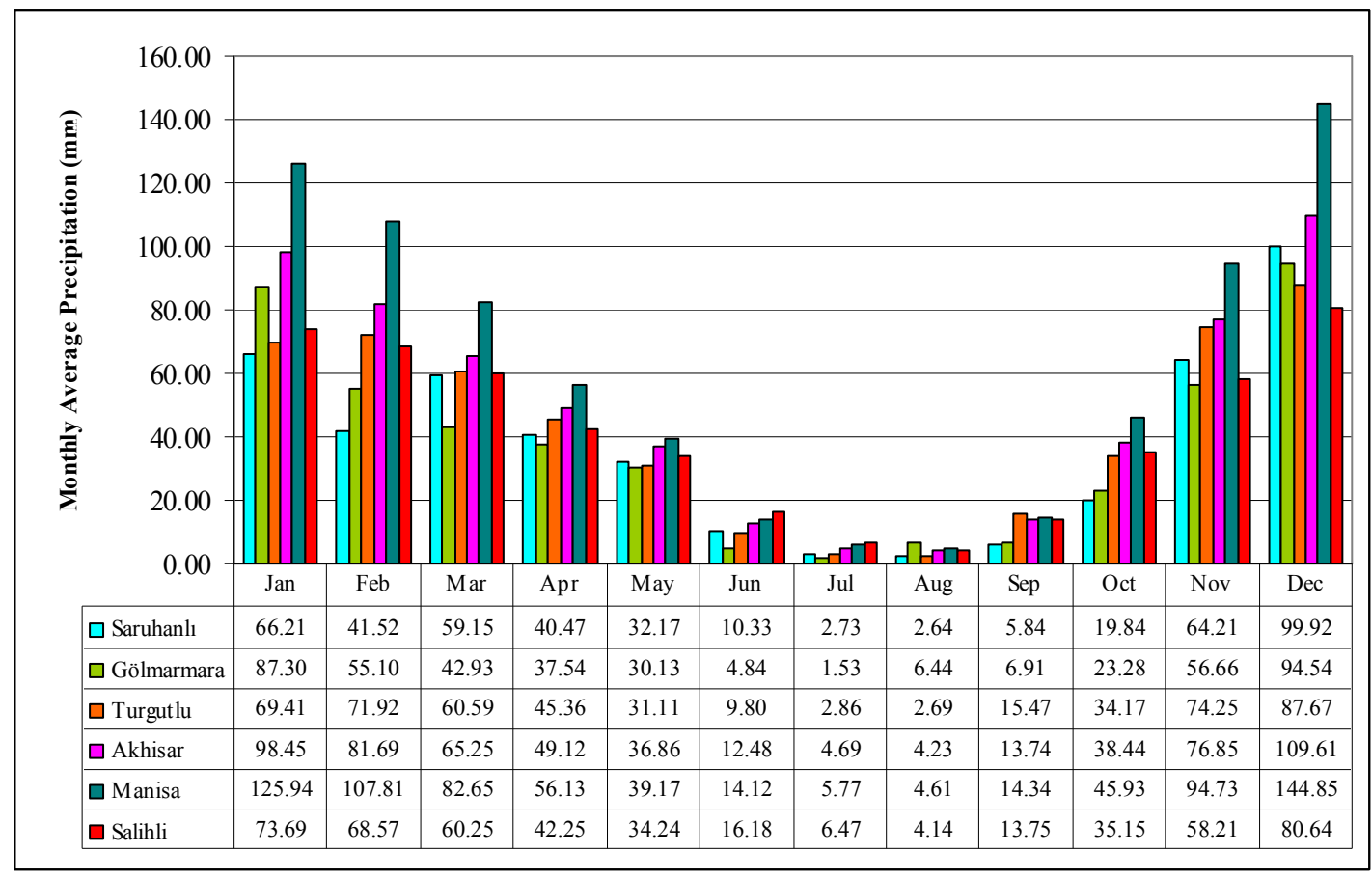

Figure 2.3: Monthly average precipitation graph for each station 
Table 2.4: Monthly average, minimum and maximum precipitation values for each station

\begin{tabular}{|c|c|c|c|c|c|c|}
\hline & Saruhanl1 & Gölmarmara & Turgutlu & Akhisar & Manisa & Salihli \\
\hline $\begin{array}{l}\text { Minimum Monthly } \\
\text { Precipitation (mm) }\end{array}$ & DRY & DRY & DRY & DRY & DRY & DRY \\
\hline $\begin{array}{c}\text { Month \& Year of } \\
\text { Observation }\end{array}$ & Several & Several & Several & Several & Several & Several \\
\hline $\begin{array}{l}\text { Min. of the Avg. Monthly } \\
\text { Precipitation (mm) }\end{array}$ & 2.64 & 1.53 & 2.69 & 4.23 & 4.61 & 4.14 \\
\hline Month of Observation & Aug & Jul & Aug & Aug & Aug & Aug \\
\hline $\begin{array}{c}\text { Average Annual } \\
\text { Precipitation (mm) }\end{array}$ & 445.03 & 447.2 & 505.3 & 591.4 & 736.04 & 493.5 \\
\hline $\begin{array}{l}\text { Maximum Monthly } \\
\text { Precipitation (mm) }\end{array}$ & 172.2 & 199.4 & 207.8 & 351.2 & 398.7 & 236.7 \\
\hline $\begin{array}{c}\text { Month \& Year of } \\
\text { Observation }\end{array}$ & Dec-90 & Dec-90 & Feb-90 & Dec-81 & Jan-45 & Nov-55 \\
\hline $\begin{array}{l}\text { Max. of the Avg. Monthly } \\
\text { Precipitation }(\mathrm{mm})\end{array}$ & 99.92 & 94.54 & 87.67 & 109.61 & 144.85 & 80.64 \\
\hline Month of Observation & Dec & Dec & Dec & Dec & Dec & Dec \\
\hline
\end{tabular}

The results show that Manisa is the station receiving more rain on an annual basis (736.04 mm/y), and Saruhanlı (445.03 mm/y) and Gölmarmara (447.20 mm/y) receiving less precipitation. This is probably due to the availability of a longer period of record (1943-2006) at Manisa station which includes a series of wet and dry years, giving a representative annual average value. The same is also true for Salihli (19392006) and Akhisar (1943-2006) stations where long term data is available. The shortterm data collected at Saruhanlı (1986-1995) and Gölmarmara (1984-1991) correspond to a long-term dry period that existed in the region from 1982 to 1996. This can be seen clearly seen from the cumulative deviation graphs developed for Turgutlu, Akhisar, Manisa and Salihli as given in Figure 2.4 through Figure 2.7, respectively. The results show that a major wet period existed in the region between 1960 and 1982 and followed by a long-term dry period between 1982 and 1996. 


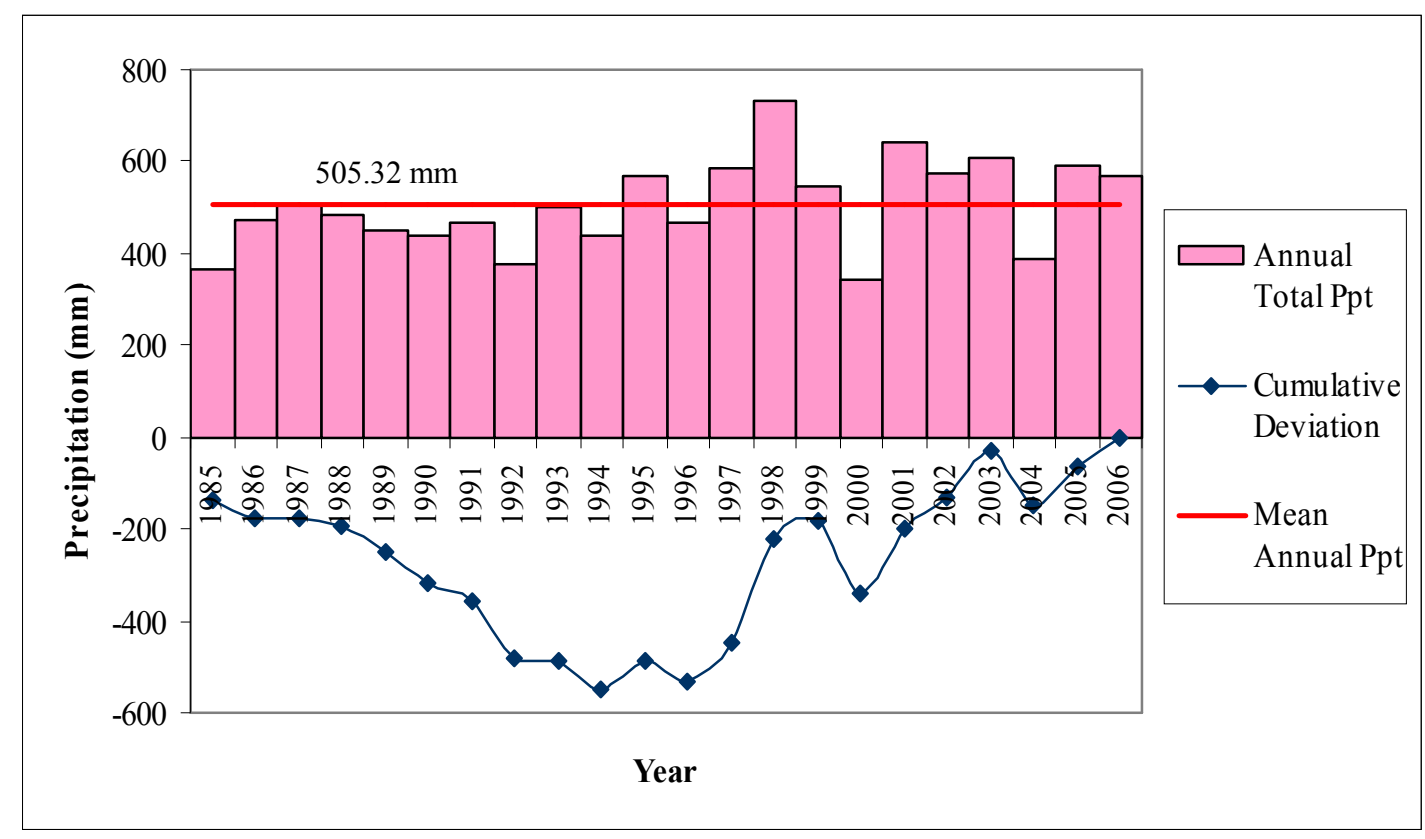

Figure 2.4: Annual precipitation distribution graph for Turgutlu station

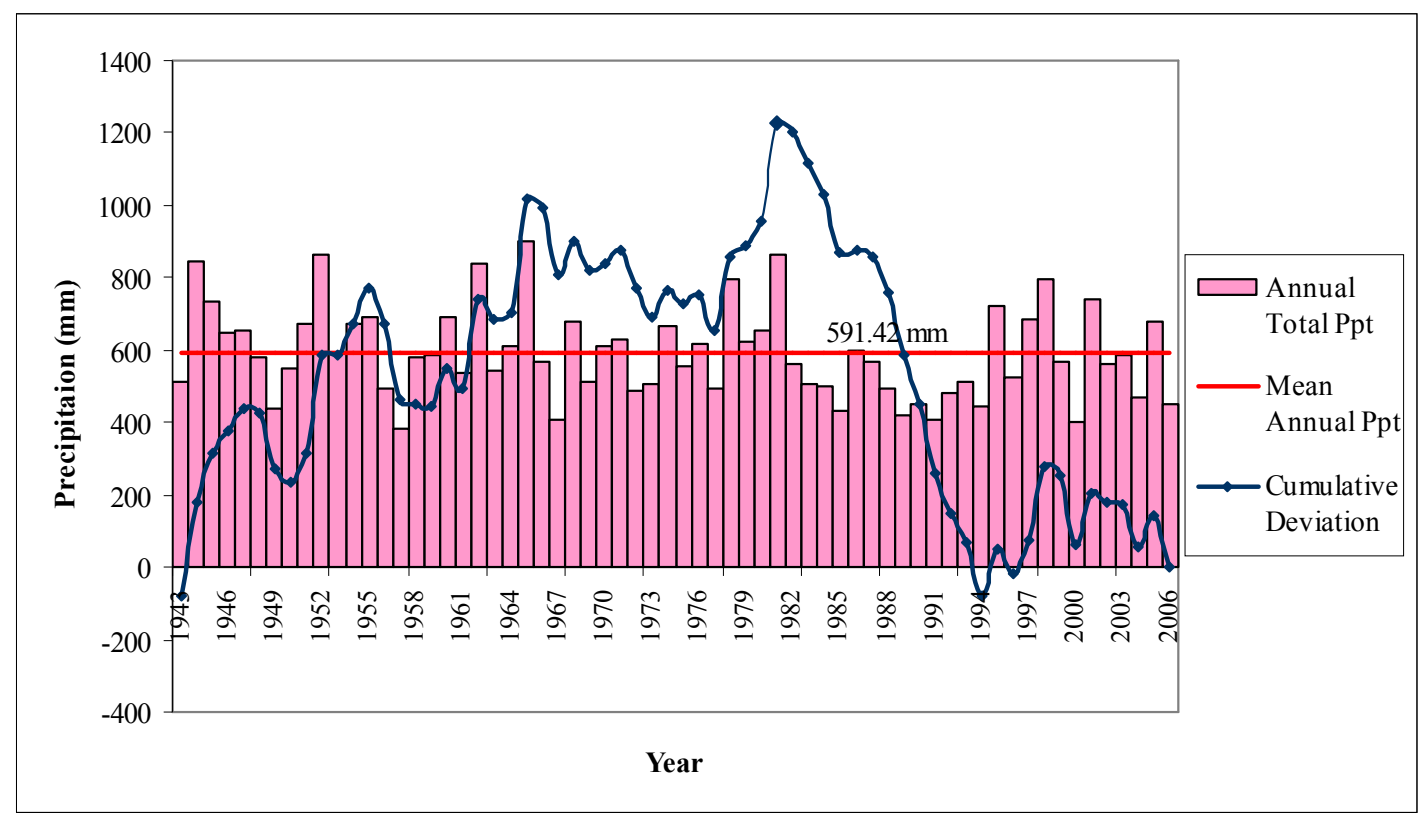

Figure 2.5: Annual precipitation distribution graph for Akhisar station 


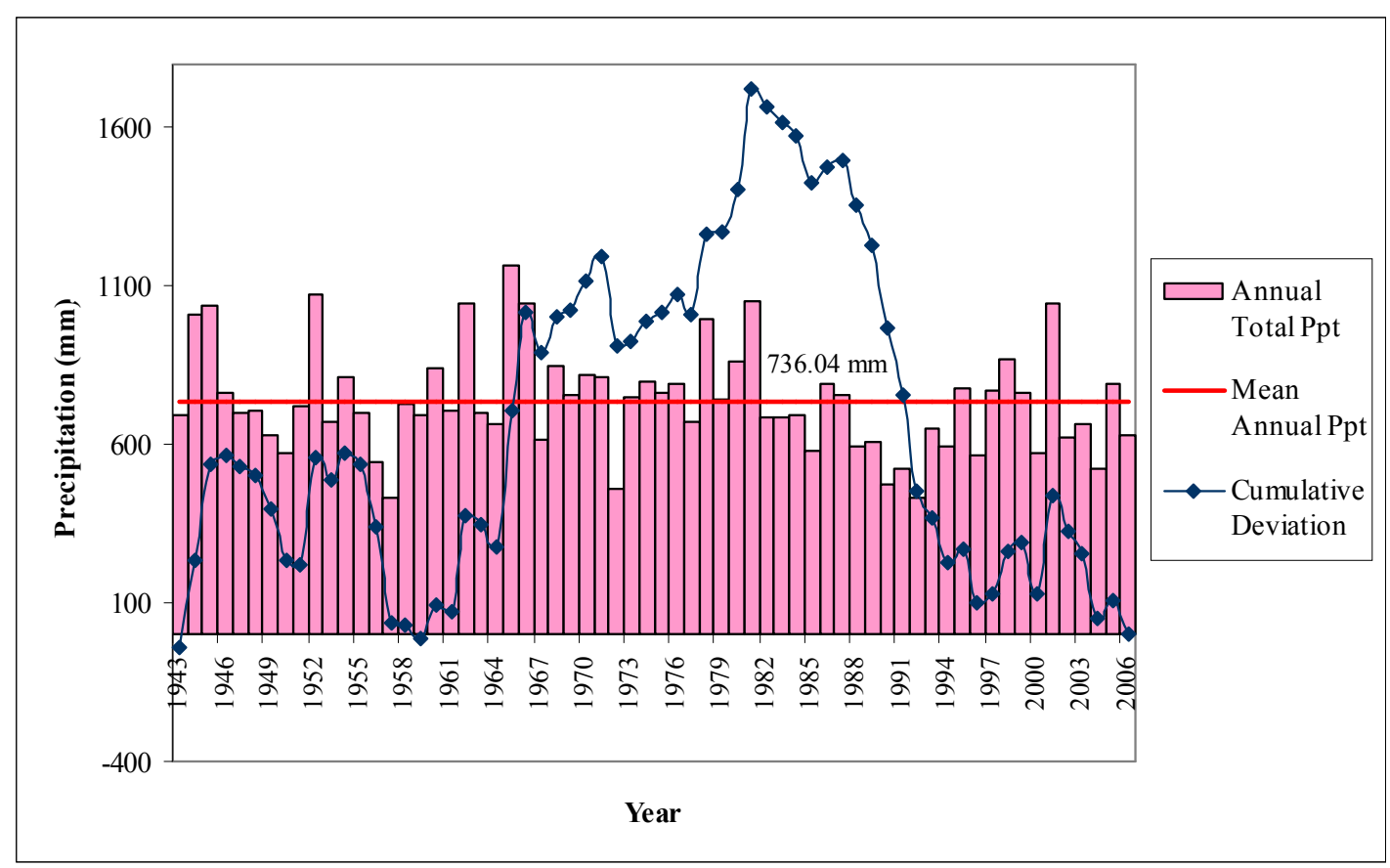

Figure 2.6: Annual precipitation distribution graph for Manisa station

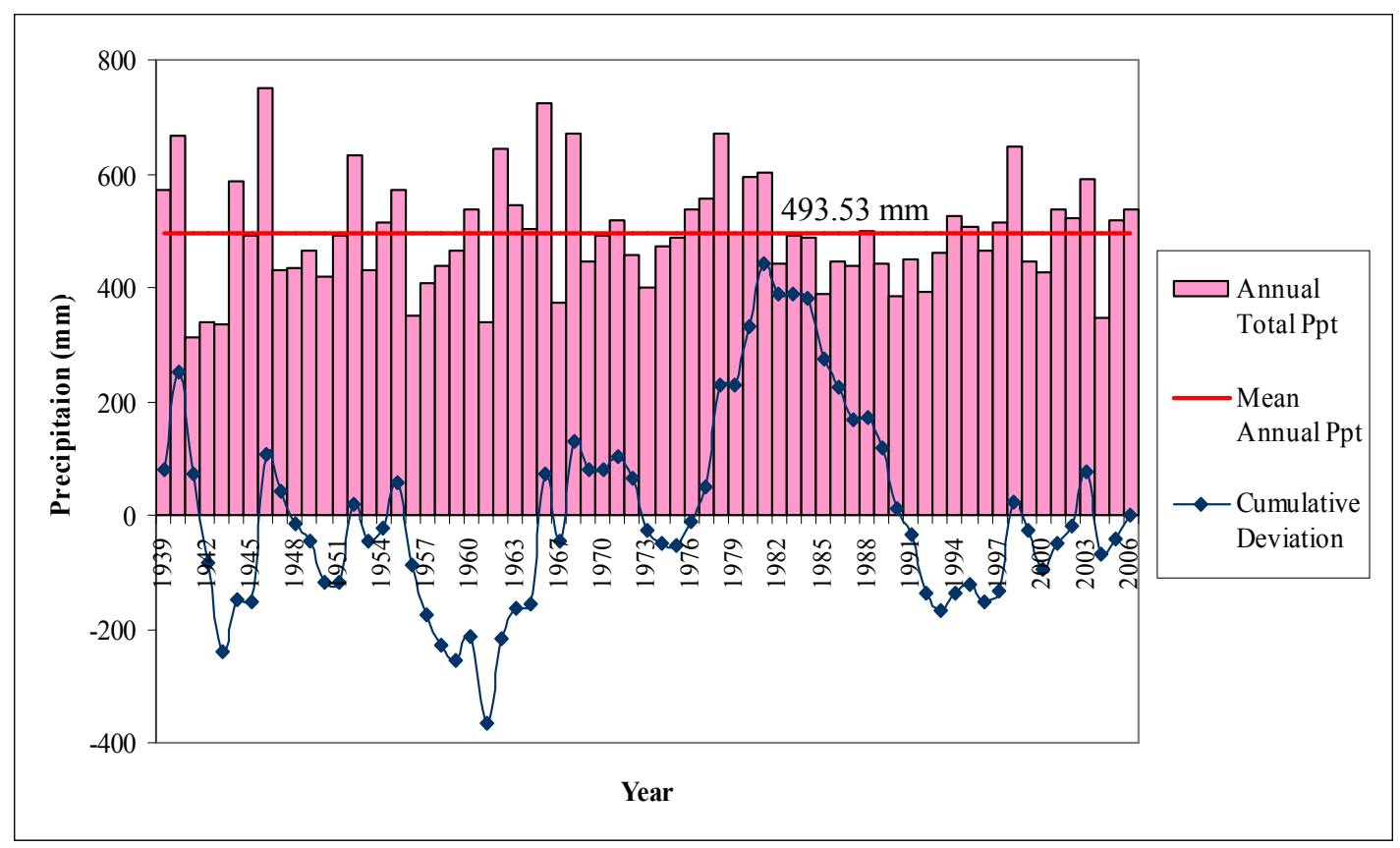

Figure 2.7: Annual precipitation distribution graph for Salihli station 


\subsubsection{Evaporation}

Evaporation data are only monitored for Akhisar and Salihli stations. Due to the availability of data from April through November, some data were missing from December through March during which the evaporation is low. The missing data were calculated by conducting correlation analyses between measured monthly evaporation and average monthly temperature data where they are available. The monthly average evaporation values for both Akhisar and Salihli stations are represented graphically in Figure 2.8. Maximum monthly average evaporation is observed in July, whereas the minimum monthly evaporation is observed in January. The annual average evaporation is $1,377 \mathrm{~mm}$.

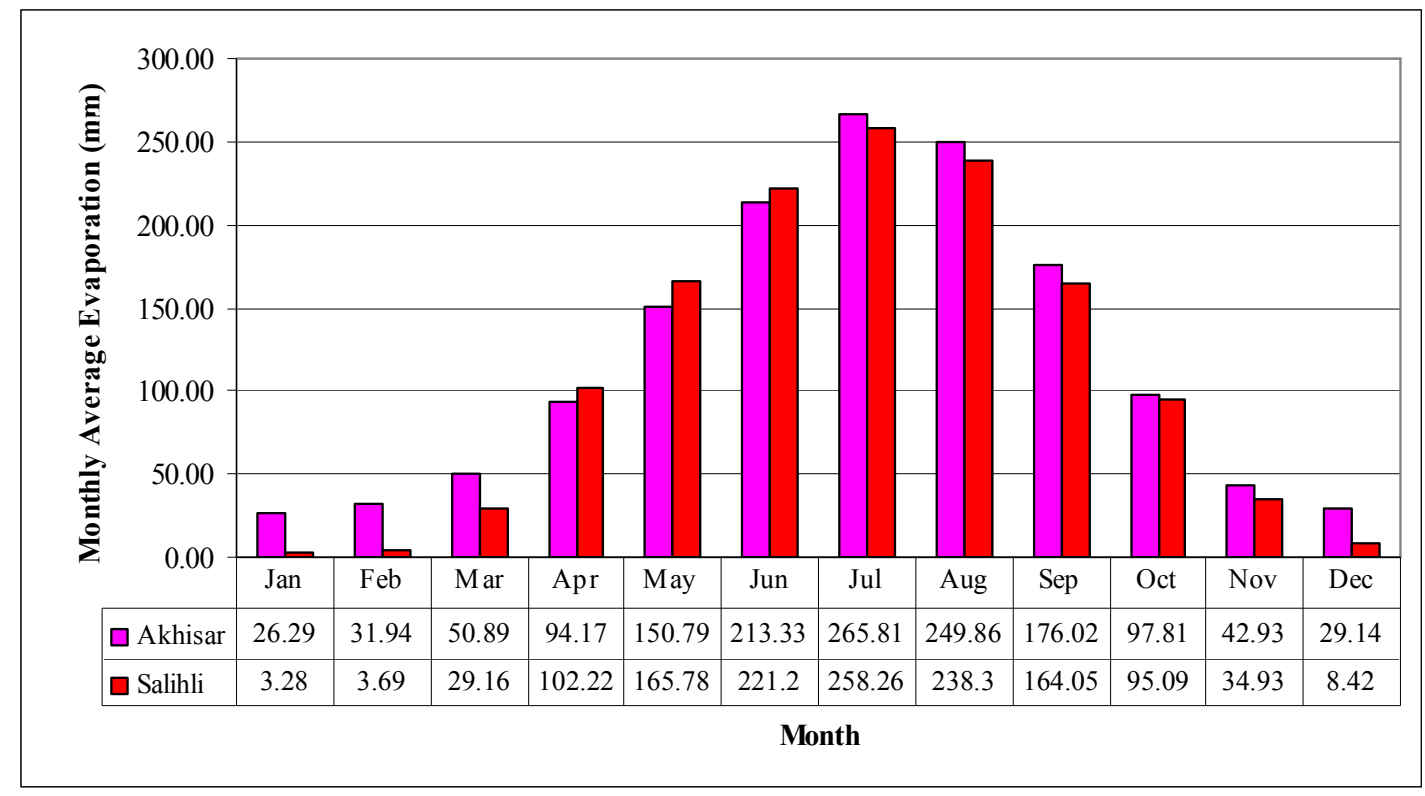

Figure 2.8: Monthly average evaporation graph for Akhisar and Salihli stations 


\subsubsection{Wind}

Monthly wind speed data for Akhisar, Manisa and Salihli stations indicate that the annual average wind speeds are between $1.0 \mathrm{~m} / \mathrm{s}$ and $3.0 \mathrm{~m} / \mathrm{s}$. The highest wind speeds are observed in July and August (Figure 2.9). Wind directions are changeable from month to month and year to year for all stations.

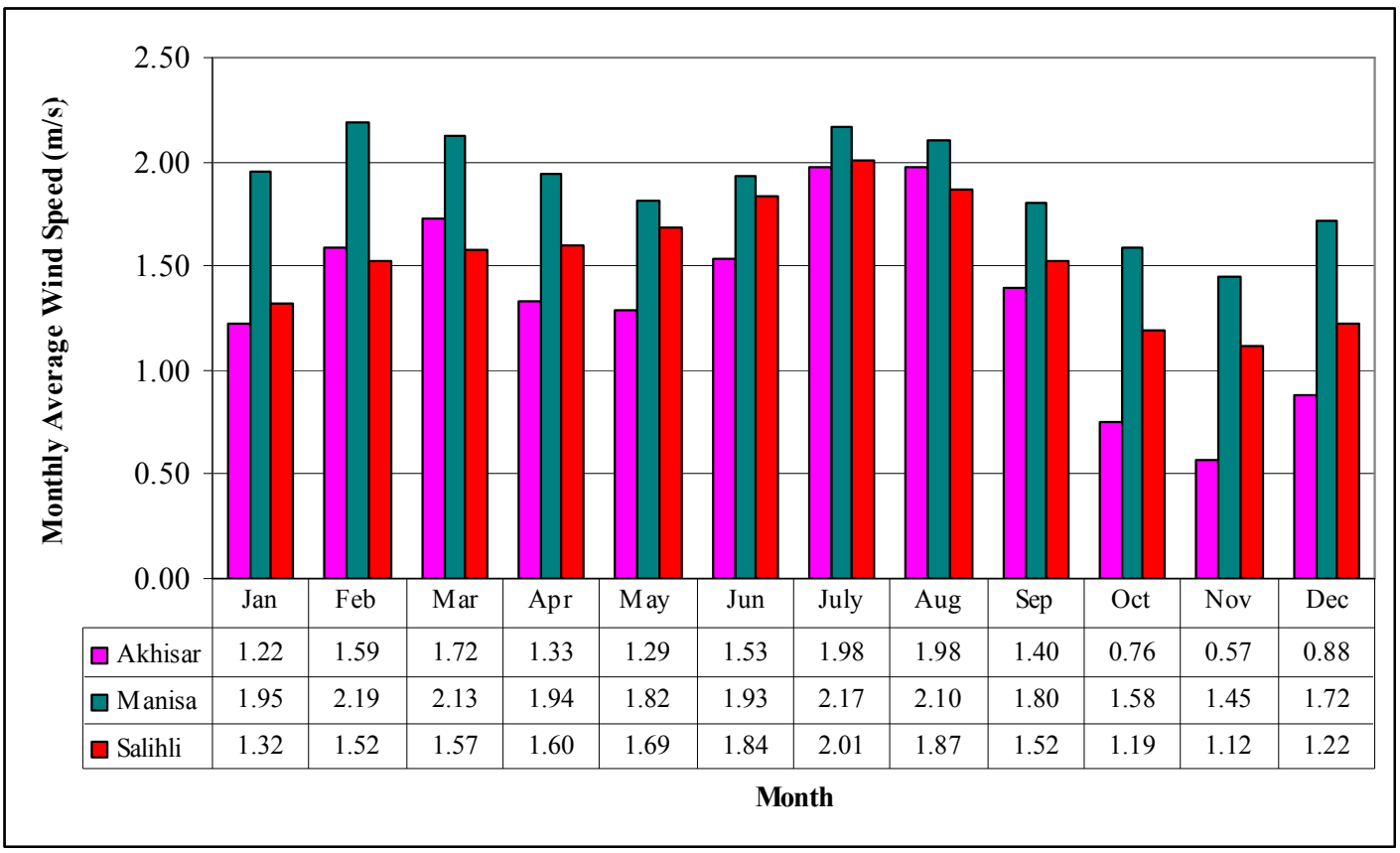

Figure 2.9: Monthly average wind speed graph for Akhisar, Manisa and Salihli stations 


\subsection{Geology}

\subsubsection{Regional Geology}

Western Turkey is one of the most tectonically active areas in Turkey. Western Turkey is characterized by the E-W trending grabens formed as a result of N-S directed extension. This extension has been continuing since latest Oligocene-Early Miocene, because of the forces exerted by subduction of the African Plate beneath the southern margin of Anatolian Plate along the Aegean-Cyprian subduction zone and the dextral slip on the North Anatolian Fault System as represented in Figure 2.10 (Bozkurt \& Sözbilir, 2004). Gediz graben is one of the best developed one in terms of thickness of accumulated sediments and the total offset occurred along the graben-bounding structures (Çiftçi \& Bozkurt, 2009). Gediz River Basin is surrounded by Bakırçay graben in the north and Küçük Menderes graben in the south (Figure 2.10).

In the Gediz River Basin, ages of the rock units cropping out vary between Paleozoic and Quaternary. The oldest formation as a basement rock is the Paleozoic aged crystalline series of Menderes Massive, which occurs as large outcrops in the Aegean Region (MTA, 1995). Menderes Massive consists of Precambrian-Early Paleozoic core rocks and overlying Paleozoic-Mesozoic rocks indicating the deposition and/or intrusion ages of the rocks before metamorphism. Granitoids are the other crystalline rock type of Menderes Massive. According to paleontological data, Menderes Massive completed its metamorphism before Late Paleocene (Yazicigil, 2008). Thickness of these units ranges in between $250 \mathrm{~m}$ and $500 \mathrm{~m}$ (MTA, 1995). 


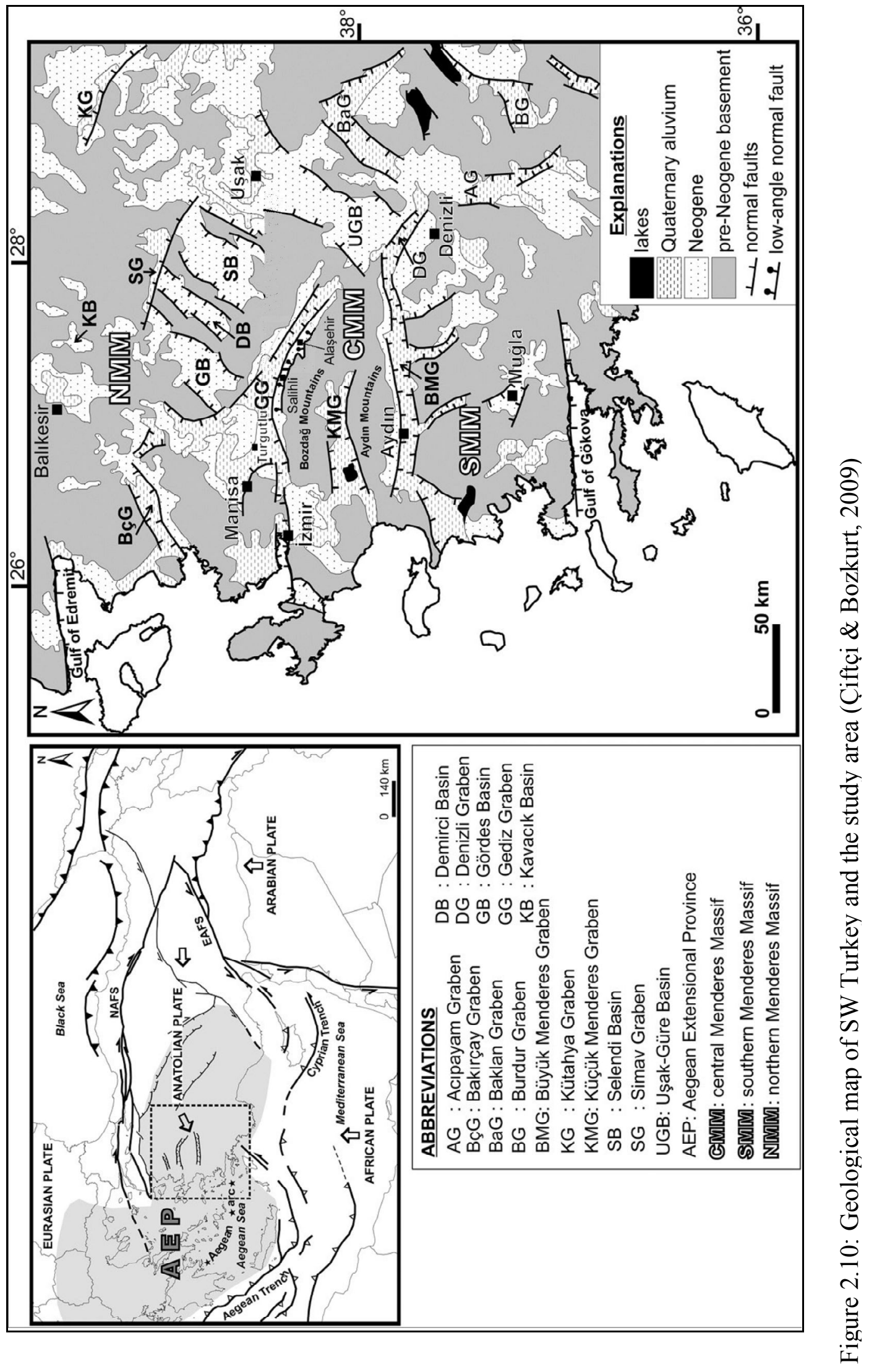


Menderes Massive is overlain by Mesozoic aged formations with a tectonic contact (MTA, 1995). These rocks are the İzmir-Ankara suture zone rocks represented with an accreational prism consisting of ultrabasic, serpentinized ultrabasic and spilitic volcanic rocks with a Late Cretaceous - Paleocene pelagic matrix of sandstone, mudstone, claystone, limestone, radiolarite and chert. Mesozoic aged, neritic, dolomitic limestone blocks occur as olistoliths in this matrix (Yazıcıgil, 2008).

Mesozoic units are unconformably overlain by Neogene formations (MTA, 1995). Neogene formations can be grouped into two units: Miocene and Pliocene units. Conglomerate, sandstone, marl, siltstone, limestone and rarely andesite are the Miocene aged rocks. Pliocene aged rocks are conglomerate, sandstone, siltstone, claystone and tuff. Rocks comprising these formations were deposited in different stages and facies such as river and lacustrine (MTA, 1995). The age of these rocks were assigned according to pollen assemblages and fossils (Bozkurt \& Sözbilir, 2004).

Quaternary sediments cover all of the sequence. Old alluvium, young alluvium and travertine comprise the Quaternary units. There are numerous travertines in the Gediz River Basin. Some of them have been continuing to deposit. Quaternary sediments display different thicknesses at different location depending on the tectonic activities in the Gediz River Basin (MTA, 1995). Quaternary volcanics are rarely seen in the Gediz River Basin.

Menderes Massive is in the structure of a complex nappe pile which shaped with the compression tectonics of Late-Alpine. İzmir-Ankara suture zone rocks cover the Menderes Massive with a tectonic contact (Yazıcigil, 2008). The most prominent structures of the Western Turkey are grabens. As mentioned before, these E-W trending grabens have been developing as a result of N-S directed extension zone since Latest Oligocene-Early Miocene (Bozkurt \& Sözbilir, 2004). Reasons of this extension are subduction roll-back along the Aegean-Cyprian trench, westward escape of the Anatolian micro-plate along dextral North Anatolian and sinistral East 
Anatolia fault system, post-orogenic collapse of the crust overthickened during the closure of the northern branch of Neotethys, and different convergence rates along the Aegean-Cyprian subduction zone. As a result, the low-angle north dipping normal faults and high-angle normal faults forming the Gediz graben were developed. Low-angle faults named as Gediz detachment are along the southern margin of the Gediz graben. High-angle faults control both the southern and northern margins of the graben. General orientations of these faults are E-W to WNW-ESE or ENE-WSW (Çiftçi \& Bozkurt, 2009).

\subsubsection{Local Geology}

The study area comprises the Turgutlu, Ahmetli and Salihli towns, and is bounded by Demirköprü Dam in the east and Gölmarmara Lake in the north as seen in Figure 1.2. Due to the location of the study area (Western Turkey), the main structural elements in the study area are normal faults, strike-slip faults, reverse faults, overthrust faults and folds which started to develop with the closure of the İzmir-Ankara ocean in the Paleocene, continued with the development of graben in the Neogene and the faults that generate low intensity earthquakes at present time (Yazıcıgil, 2008).

The dominant formations in the study area are Paleozoic, Neogene and Quaternary units. As mentioned in the Regional Geology part, the basement rock is Paleozoic aged Menderes Massive metamorphic rocks which consist of gneiss, micaschist, quartzite and marble (MTA, 1995). The basement rocks crop out along the margins of the basin in the south and the north. Çakaldoğan granite is observed in southeastern part of the study area with a very limited amount. Çakaldoğan granite includes plagioclase, quartz, chloritized biotite, partly chloritized hornblende and a small amount of microcline (MTA, 1995). These series are overlain by Mesozoic aged İzmir-Ankara suture zone rocks with a tectonic contact. Limited and disconnected outcrops of Mesozoic formations are observed in mostly north and west of the study area as shown in Figure 2.11. Neogene units cover all of the sequence 
with an unconformity. They are represented by two groups; Miocene rocks and Pliocene rocks. Miocene units generally expand through the northern part of the Gediz Plain, generally around north of the Manisa, Turgutlu and Salihli Plain. Southern part of the study area is dominated with Pliocene units (MTA, 1995). The upper layer in the study area is made up of Quaternary travertine and sediments carried by the Gediz River and its tributaries (Yazıcigil, 2008). These sediments comprise the alluvium and alluvial fans. The alluvium and alluvial fans are made up of rubble, gravel, sand, silt and clay. Alluvium materials become finer from hill side to river. In northern part of the Gediz River in the study area, alluvium spreads in a small area whereas it shows a wide spread in the south. Along the Gediz graben, the boundary between Quaternary and Neogene units is very sharp because of faulting. The Gediz River is closer to the northern boundary than southern boundary. So, sediments carried by tributaries of Gediz River fill the southern part more than the northern part of the Gediz River.

The geological map of the study area was developed by using the geological maps prepared by DSİ (1983) and MTA (1995). The geological map of the study area with the distribution of the units explained above is given in Figure 2.11. The stratigraphic sequence of the basin is shown in the generalized columnar section given in Figure 2.12 . 


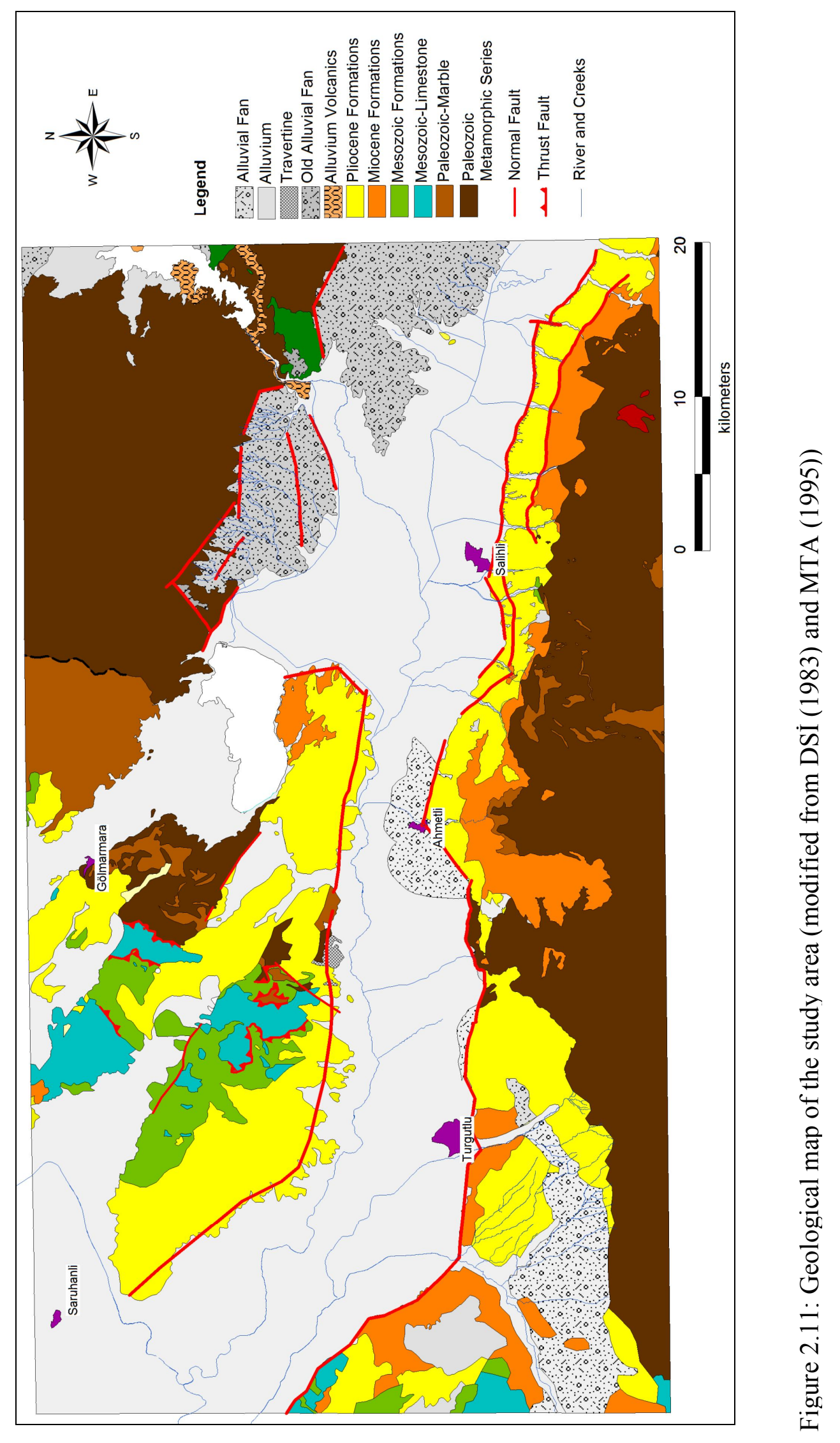




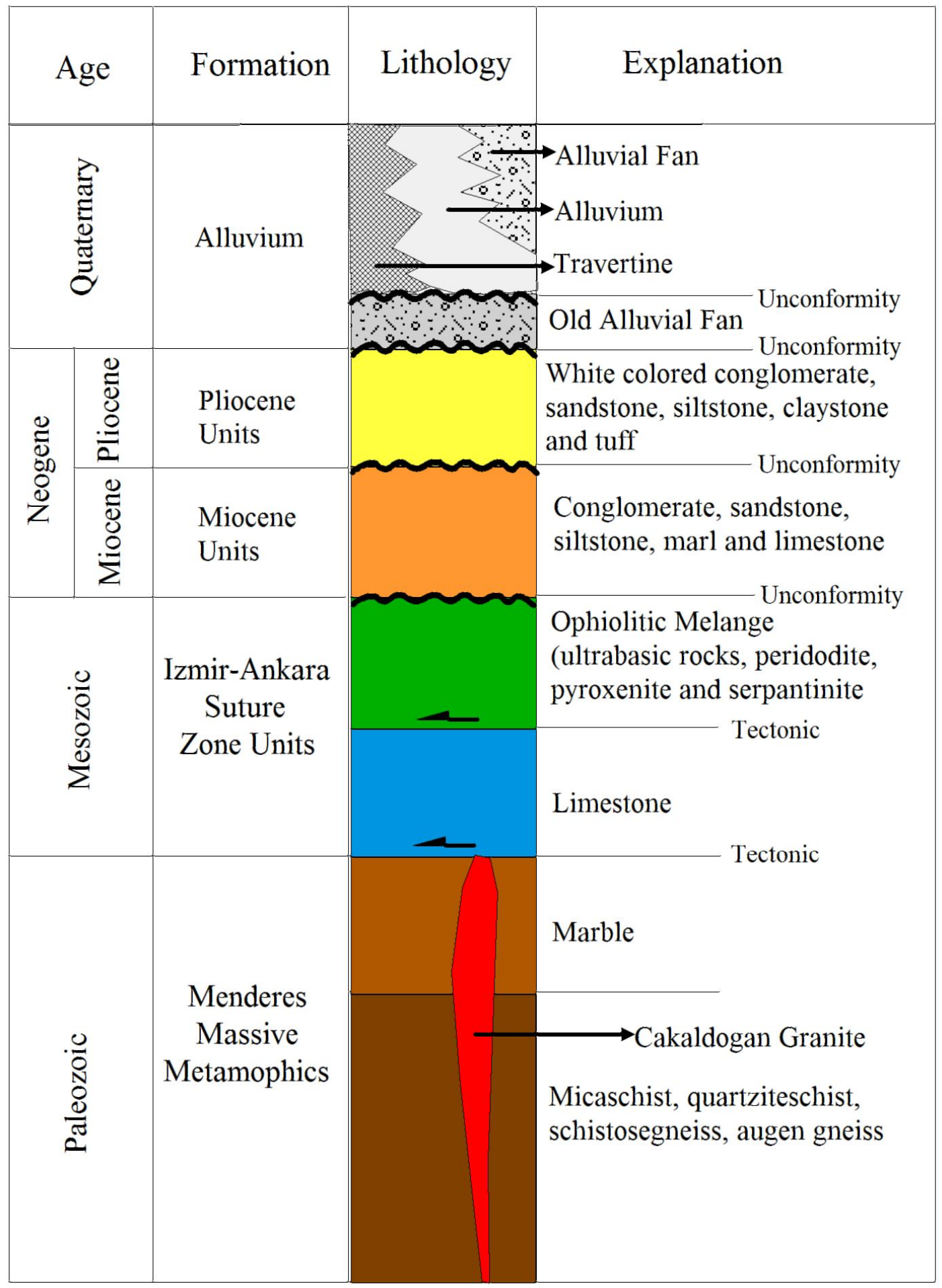

Figure 2.12: Generalized columnar section of the study area (modified from MTA (1995)) 


\section{CHAPTER 3}

\section{HYDROGEOLOGY}

\subsection{Water Resources}

\subsubsection{Surface Water Resources}

Gediz River is the major water resource within the study area. Nif, Taytan, Gümüş, Kurşunlu, Tabak, Sart, Ahmetli, Irlamaz are the creeks joining the Gediz River as displayed in Figure 3.1 .

Gediz River enters the study area from Adala Regulator at the south of the Demirköprü Dam (Figure 3.1). It flows in E-W direction and leaves the study area at the northwestern boundary. Numerous creeks discharge to Gediz River. Demirköprü Dam, and Adala and Ahmetli Regulators (Figure 3.1) are the water structures on Gediz River.

There are nine flow monitoring stations located at the studied portion of the Gediz River. Three of the stations are operated by DSI and the rest is operated by EIEI (General Directorate of Electrical Power Resources Survey and Development Administration) (Figure 3.2). Seven of these are in the study area, and the remaining two are around the study area as shown in Figure 3.2. Information about the flow monitoring stations is given in Table 3.1. 


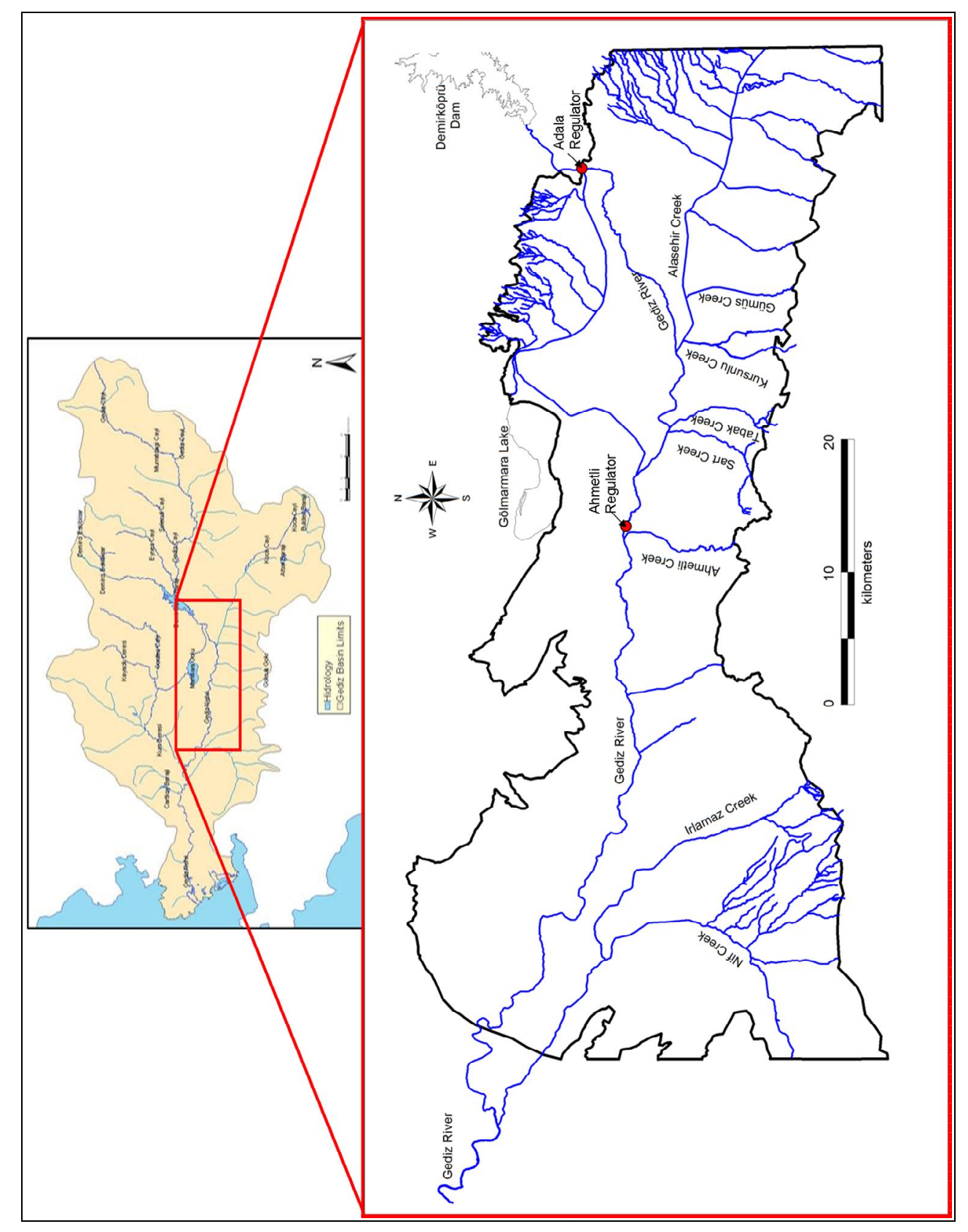

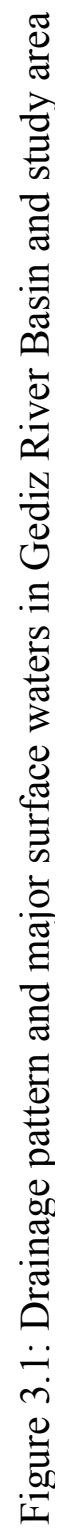




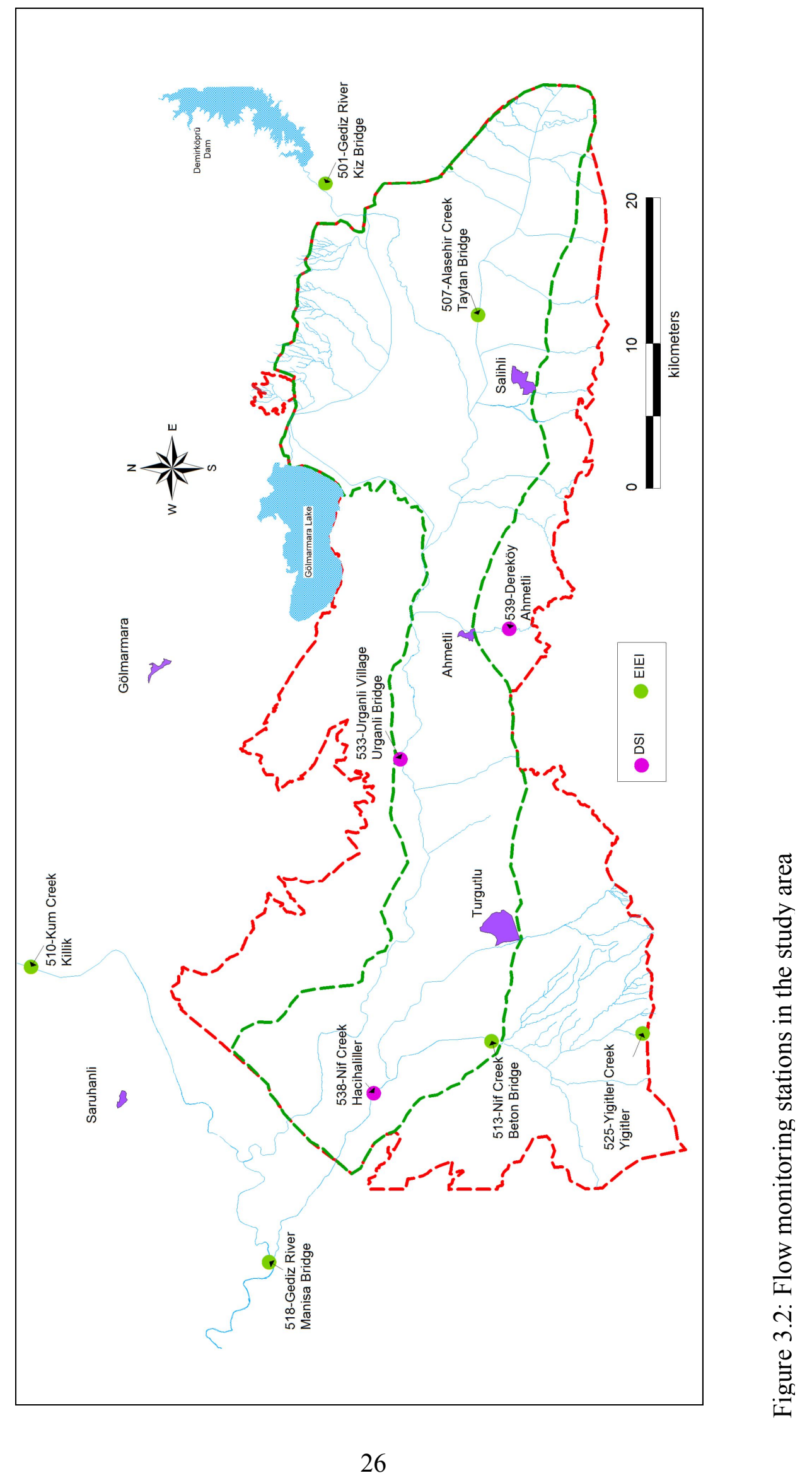


Table 3.1: Information about the flow monitoring stations

\begin{tabular}{|c|c|c|c|c|c|c|}
\hline \multirow{2}{*}{$\begin{array}{l}\text { Station } \\
\text { No }\end{array}$} & \multirow{2}{*}{ River - Station Name } & \multicolumn{2}{|c|}{ Coordinates } & \multirow{2}{*}{$\begin{array}{l}\text { Elevation } \\
\text { (m) }\end{array}$} & \multirow{2}{*}{$\begin{array}{l}\text { Operation } \\
\text { Period }\end{array}$} & \multirow{2}{*}{$\begin{array}{l}\text { Operating } \\
\text { Institution }\end{array}$} \\
\hline & & Easting & Northing & & & \\
\hline 501 & Gediz River-Kız Bridge & 613001 & 4273766 & 150 & $1939-1956$ & EİEI \\
\hline 507 & $\begin{array}{c}\text { Alaşehir Creek - Taytan } \\
\text { Bridge }\end{array}$ & 603949 & 4263288 & 93 & $\begin{array}{l}1952-1953, \\
1962-1968\end{array}$ & EİĖ \\
\hline 510 & Kum Creek - Killik & 558886 & 4293958 & 55 & $\begin{array}{l}\text { 1952-1954, } \\
1961-2000\end{array}$ & EIEİ \\
\hline 513 & Nif Creek - Beton Bridge & 553792 & 4262362 & 52 & 1969-1974 & EİEİ \\
\hline 518 & $\begin{array}{c}\text { Gediz River - Manisa } \\
\text { Bridge } \\
\end{array}$ & 538486 & 4277621 & 23 & $\begin{array}{l}1962-2001, \\
2004\end{array}$ & EIEİ \\
\hline 525 & Yiğitler Creek - Yiğitler & 553468 & 4252029 & 165 & $1975-2000$ & EİEI \\
\hline 533 & $\begin{array}{c}\text { Urganlı Village - Urganlı } \\
\text { Bridge }\end{array}$ & 573206 & 4268619 & 58 & $\begin{array}{l}\text { 1983-1994, } \\
2001,2004\end{array}$ & DSİ \\
\hline 538 & Nif Creek - Hacihaliller & 550158 & 4270439 & 31 & 1994-1996 & DSI \\
\hline 539 & Dereköy - Ahmetli & 582240 & 4261149 & 125 & 1994-2007 & DSİ \\
\hline
\end{tabular}

Long term monthly and annual average flow rates at all of these stations are summarized in Table 3.2. Annual discharge at stations 518 and 533 are shown graphically in Figure 3.3 and 3.4, respectively. Stations 518 and 533 have a drainage area of $15,616.4 \mathrm{~km}^{2}$ and $9,587 \mathrm{~km}^{2}$, respectively. Monthly river flow rates of these two stations given in Figure 3.5 clearly explain the effect of winter rainfall and the controlled releases of discharges from Demirköprü Dam and Gölmarmara Lake. The flow rates reach their maximum rate at winter and early spring (January through March) because of amount of winter rainfall. Although the flow rates should be lower in summer and fall months, they are however at moderate levels in July and August as it is seen in Figure 3.5. This is primarily due to the release of water from Demirköprü Dam and Gölmarmara Lake in July and August. Monthly average discharge for station 518 reaches its maximum value of $85.91 \mathrm{~m}^{3} / \mathrm{s}$ in February and its minimum value of $19.29 \mathrm{~m}^{3} / \mathrm{s}$ in June. Maximum and minimum monthly discharges occurred in February 1964 as $460 \mathrm{~m}^{3} / \mathrm{s}$ and September 1993 as $0.1 \mathrm{~m}^{3} / \mathrm{s}$, respectively. Similar results in monthly average river flow rates are observed in station 533 with significantly smaller flow rates. The monthly average discharges at station 533 ranges in between $22.45 \mathrm{~m}^{3} / \mathrm{s}$ in February as a maximum value and 4.88 $\mathrm{m}^{3} / \mathrm{s}$ in September as a minimum value. Maximum monthly discharge of $115.1 \mathrm{~m}^{3} / \mathrm{s}$ observed in February 1984, and the minimum monthly discharge of $0.165 \mathrm{~m}^{3} / \mathrm{s}$ observed in September 1992 at station 533. 
Table 3.2: Monthly and annual average flow rates recorded at the flow monitoring stations in the study area $\left(\mathrm{m}^{3} / \mathrm{s}\right)$

\begin{tabular}{|c|c|c|c|c|c|c|c|c|c|c|c|c|c|}
\hline \multirow{2}{*}{$\begin{array}{c}\text { Station } \\
\text { No }\end{array}$} & \multicolumn{10}{|c|}{ Monthly Average } & \multirow{2}{*}{$\begin{array}{c}\text { Annual } \\
\text { Average }\end{array}$} \\
\cline { 2 - 15 } & Oct & Nov & Dec & Jan & Feb & Mar & Apr & May & Jun & Jul & Aug & Sep & \\
\hline 501 & 5.33 & 9.78 & 37.29 & 59.58 & 74.71 & 51.44 & 35.21 & 24.15 & 11.78 & 4.91 & 2.52 & 3.74 & 26.70 \\
\hline 507 & 0.42 & 1.88 & 14.56 & 28.68 & 29.65 & 30.17 & 15.21 & 8.68 & 3.29 & 0.41 & 0.28 & 0.40 & 11.30 \\
\hline 510 & 1.25 & 2.13 & 7.53 & 13.02 & 16.28 & 11.21 & 8.29 & 4.90 & 2.28 & 0.96 & 0.48 & 0.86 & 5.82 \\
\hline 513 & 1.05 & 1.03 & 4.15 & 4.39 & 11.13 & 11.83 & 5.44 & 2.43 & 1.33 & 0.83 & 0.77 & 1.06 & 3.86 \\
\hline 518 & 21.00 & 24.63 & 47.68 & 73.86 & 85.91 & 74.37 & 53.80 & 33.15 & 19.29 & 23.47 & 25.53 & 21.96 & 42.00 \\
\hline 525 & 0.12 & 0.26 & 1.16 & 1.77 & 1.86 & 1.49 & 1.10 & 0.49 & 0.16 & 0.07 & 0.05 & 0.05 & 0.72 \\
\hline 533 & 8.63 & 9.44 & 12.95 & 21.22 & 22.45 & 17.65 & 13.62 & 8.17 & 5.02 & 14.93 & 13.40 & 4.88 & 12.70 \\
\hline 538 & 0.31 & 0.68 & 2.20 & 5.40 & 7.04 & 9.03 & 8.35 & 2.42 & 0.61 & 1.14 & 0.99 & 0.41 & 2.55 \\
\hline 539 & 0.16 & 0.36 & 0.83 & 3.50 & 2.23 & 1.55 & 1.03 & 0.55 & 0.23 & 0.06 & 0.04 & 0.09 & 0.89 \\
\hline
\end{tabular}

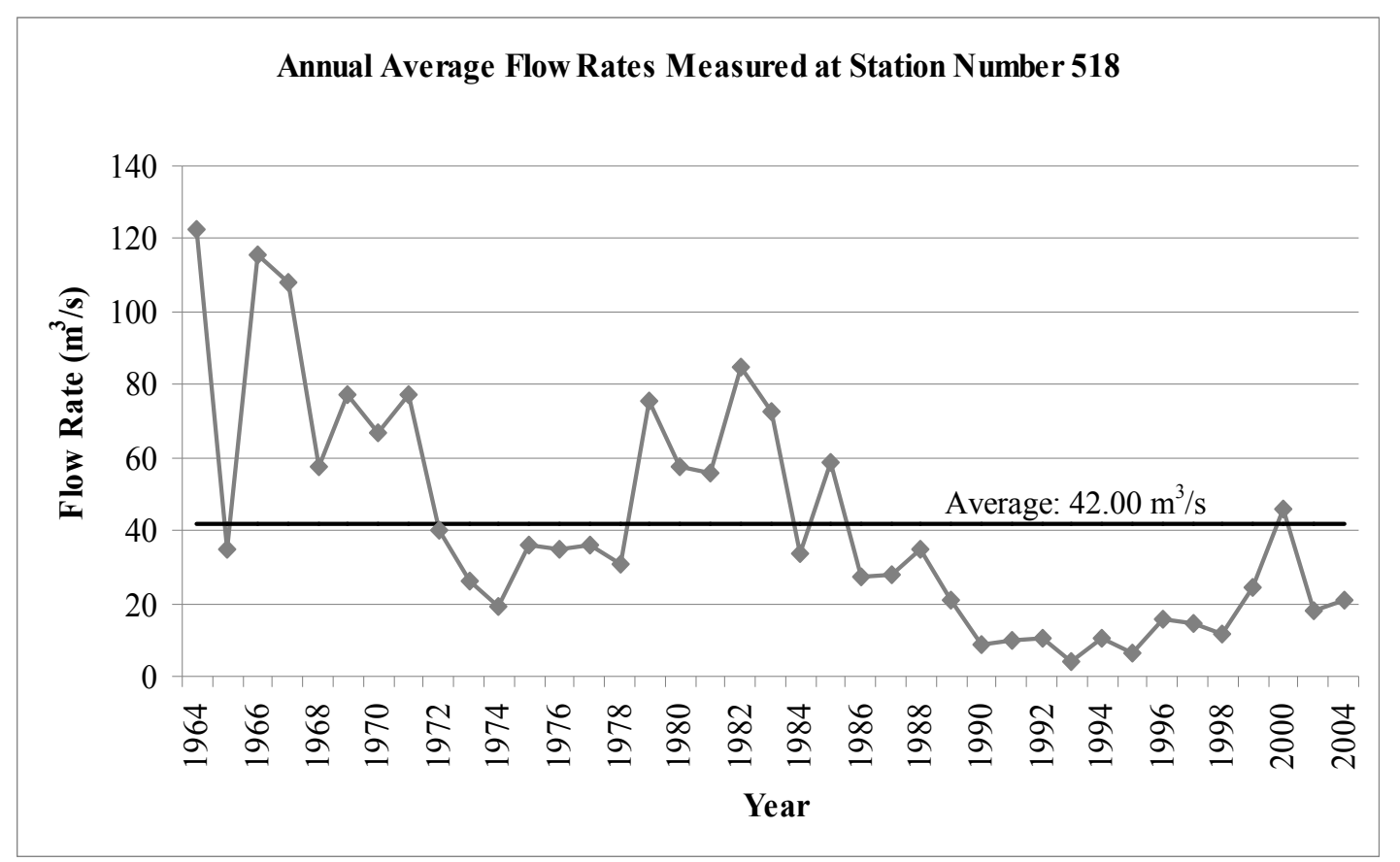

Figure 3.3: Annual average flow rates measured at station number 518 


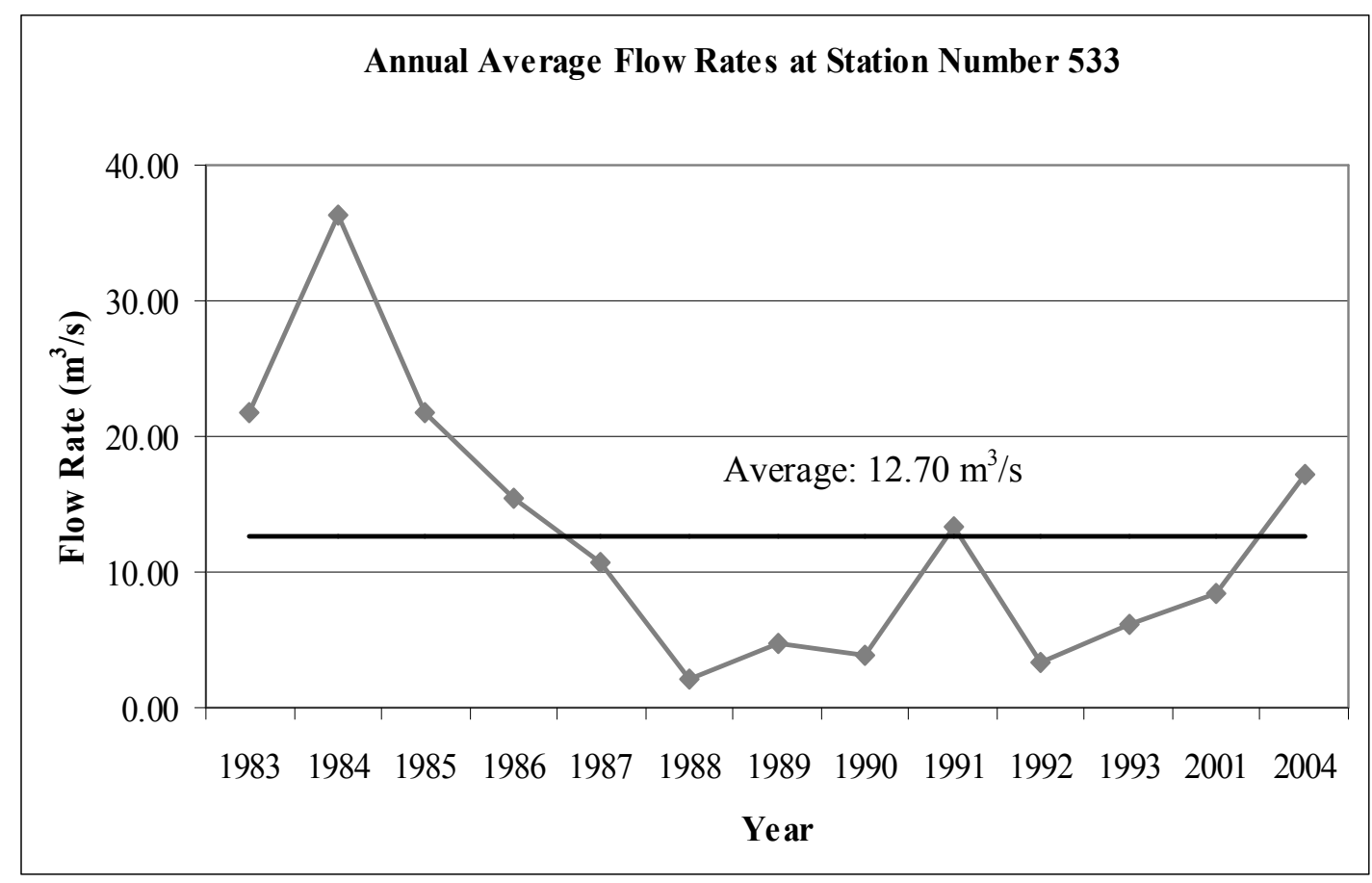

Figure 3.4: Annual average flow rates measured at station number 533

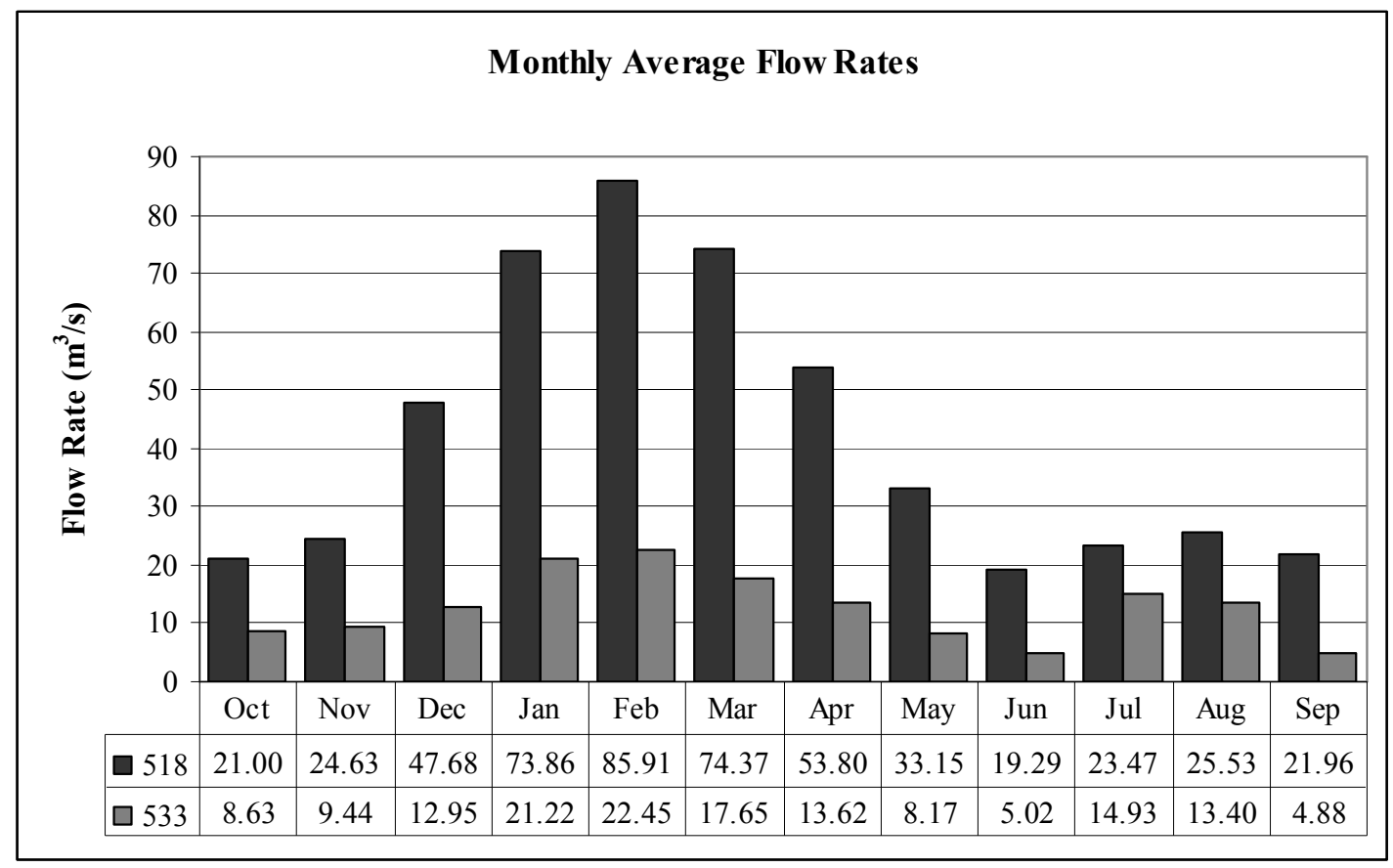

Figure 3.5: Monthly average flow rates at station number 518 and 533 
Annual average flow rates at station 518 and 533 for period of available data are given in Figure 3.3 and Figure 3.4. The average annual flow rate at station 518 varies from $4.04 \mathrm{~m}^{3} / \mathrm{s}$ in 1993 to $123.00 \mathrm{~m}^{3} / \mathrm{s}$ in 1964 , and the average being equal to 42.00 $\mathrm{m}^{3} / \mathrm{s}$. The low annual discharge rates measured after 1982 coincide with the longterm dry period as mentioned in cumulative deviation graph from the mean annual precipitation (Figure 2.4 through Figure 2.7). The average annual flow rates at station 533 ranges in between $2.02 \mathrm{~m}^{3} / \mathrm{s}$ in 1988 and $36.29 \mathrm{~m}^{3} / \mathrm{s}$ in 1984 . The average annual flow rate of station 533 is calculated as $12.70 \mathrm{~m}^{3} / \mathrm{s}$.

\subsubsection{Springs}

In the Gediz River Basin, there are numerous springs. However, most of them are located outside the study area. Those located in the study area, Urganlı and Salihli Sart mud hot springs, have ignorable discharge rates.

\subsubsection{Surface Water Reservoirs}

Surface water reservoirs are examined into two groups: lakes and dams. Gölmarmara Lake is an artificial lake constructed by DSİ with $367 \mathrm{hm}^{3}$ of storage capacity. It is located at the northern part of the Salihli (Figure 3.2). Southeastern part of the lake was raised by bank and a regulator was constructed to supply water for irrigation (DSİ, 1983).

Demirköprü Dam is the other surface water reservoir in the study area. It is located in the northeastern part of the study area (Figure 3.2). The construction of the dam lasted for 6 years, from 1954 to 1960. Water volume, irrigating area and annual energy potential of the dam is 1,320 million $\mathrm{m}^{3}, 99,220$ hectares and $193 \mathrm{GWh}$, respectively. There is not any other dam present in the study area except Demirköprü Dam, but some other dams constructed by DSİ are located in the Gediz River Basin; namely, Afşar Dam, Bulden Dam, Gördes Dam, Sevişler Dam and Cartköy Dam. 


\subsubsection{Wells}

Wells in the study area have been drilled by different institutions for different purposes. DSİ drills wells for exploration, drinking-domestic supply and irrigation purposes. Aim of the Bank of Provinces is to meet the drinking water needs of the municipalities. Individual wells are drilled by private people for different purposes, as water supply and irrigation.

In the studied part of the Gediz River Basin, there are nearly 3700 wells drilled by DSİ, Bank of Provinces, and municipalities and individuals. After the detailed examination of these wells, all the information (well logs, coordinates, yield, staticdynamic levels, lithologies for every depth, well bottom, screen data etc.) of approximately 3500 of these wells is available in the records of $2^{\text {nd }}$ District Office of DSİ. Eighty-one wells have been drilled by DSİ since 1958, 25 wells by Bank of Provinces since 1966 and nearly 3350 wells by municipalities and individuals since 1970. Drilling purposes of these wells are given in Table 3.3. Locations of these wells are shown in Figure 3.6.

Table 3.3: Purposes of wells

\begin{tabular}{|c|c|c|c|}
\hline & Water Supply & Irrigation & Exploration \\
\hline DSI & 36 & 6 & 39 \\
\hline Bank of Provinces & 25 & - & - \\
\hline Individuals & 23 & 3293 & - \\
\hline Total & 72 & 3299 & 39 \\
\hline
\end{tabular}




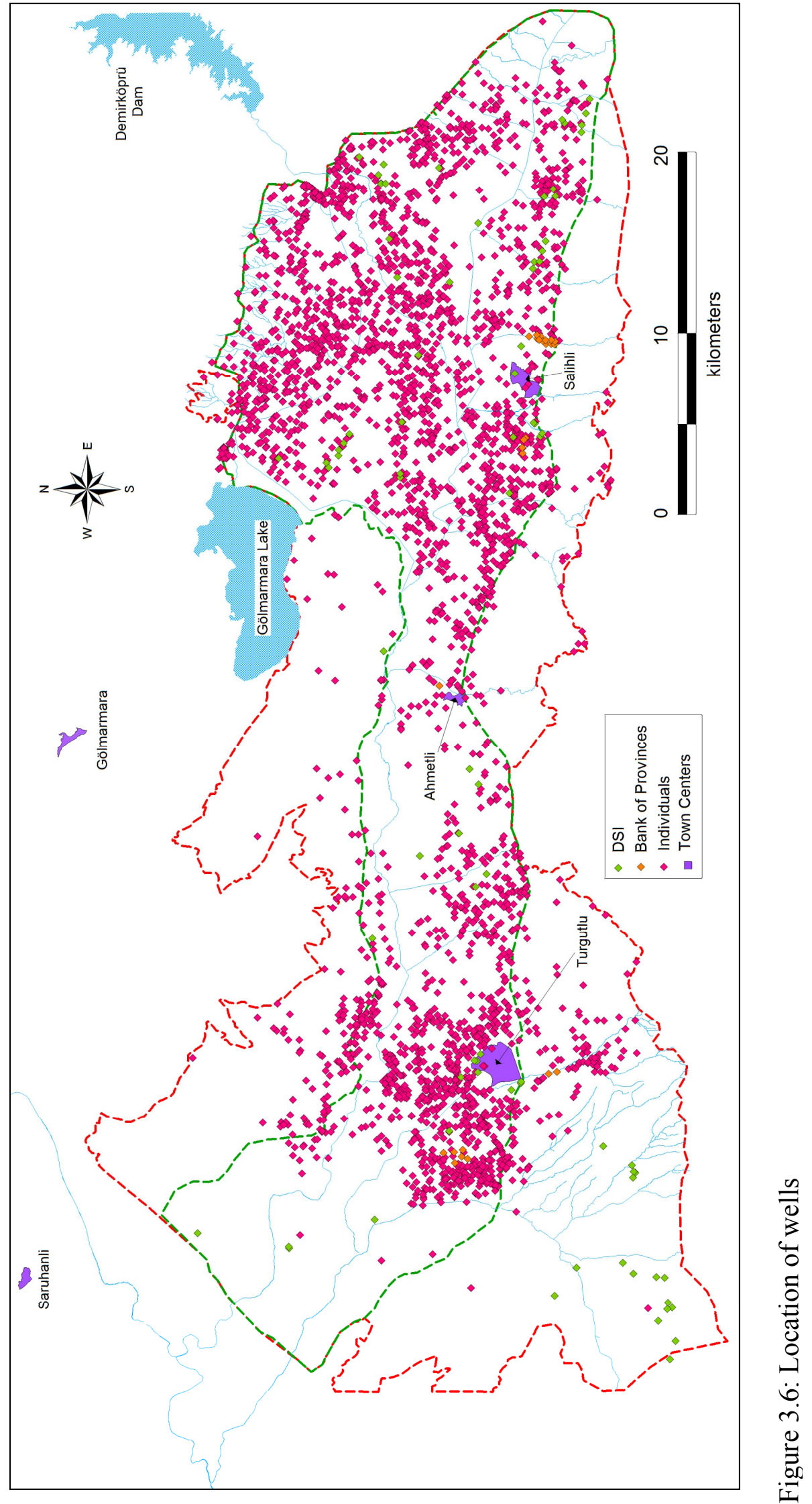


In Table 3.4, the classification of wells according to formation from which they pump water and institution that drilled the well is given. Figures 3.7 through Figure 3.10 show total number of wells drilled in various years. From these graphs, it is very obvious that there is a significant increase in the number of wells drilled after 1991. The reasons of this rapid increase could be the decreasing groundwater levels and increasing water demand.

Table 3.4: Information about wells within the study area

\begin{tabular}{|c|c|c|c|c|}
\hline & Alluvium & Neogene & Alluvium - Neogene & Total \\
\hline DSI & 72 & 1 & 8 & 81 \\
\hline Bank of Provinces & 25 & - & - & 25 \\
\hline Individuals & 3116 & 150 & 50 & 3316 \\
\hline Total & 3213 & 151 & 58 & 3422 \\
\hline
\end{tabular}

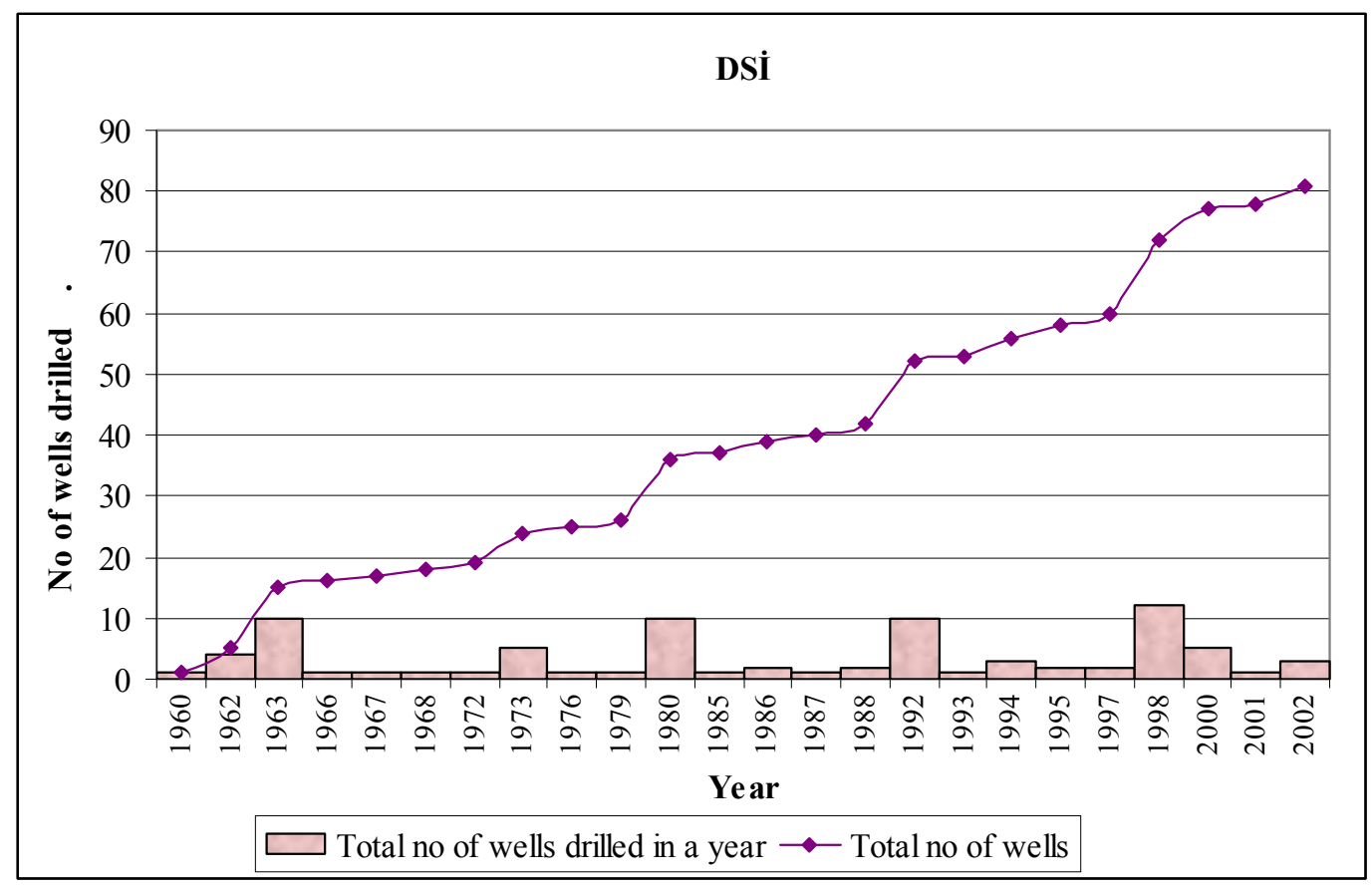

Figure 3.7: Number of wells drilled by DSI 


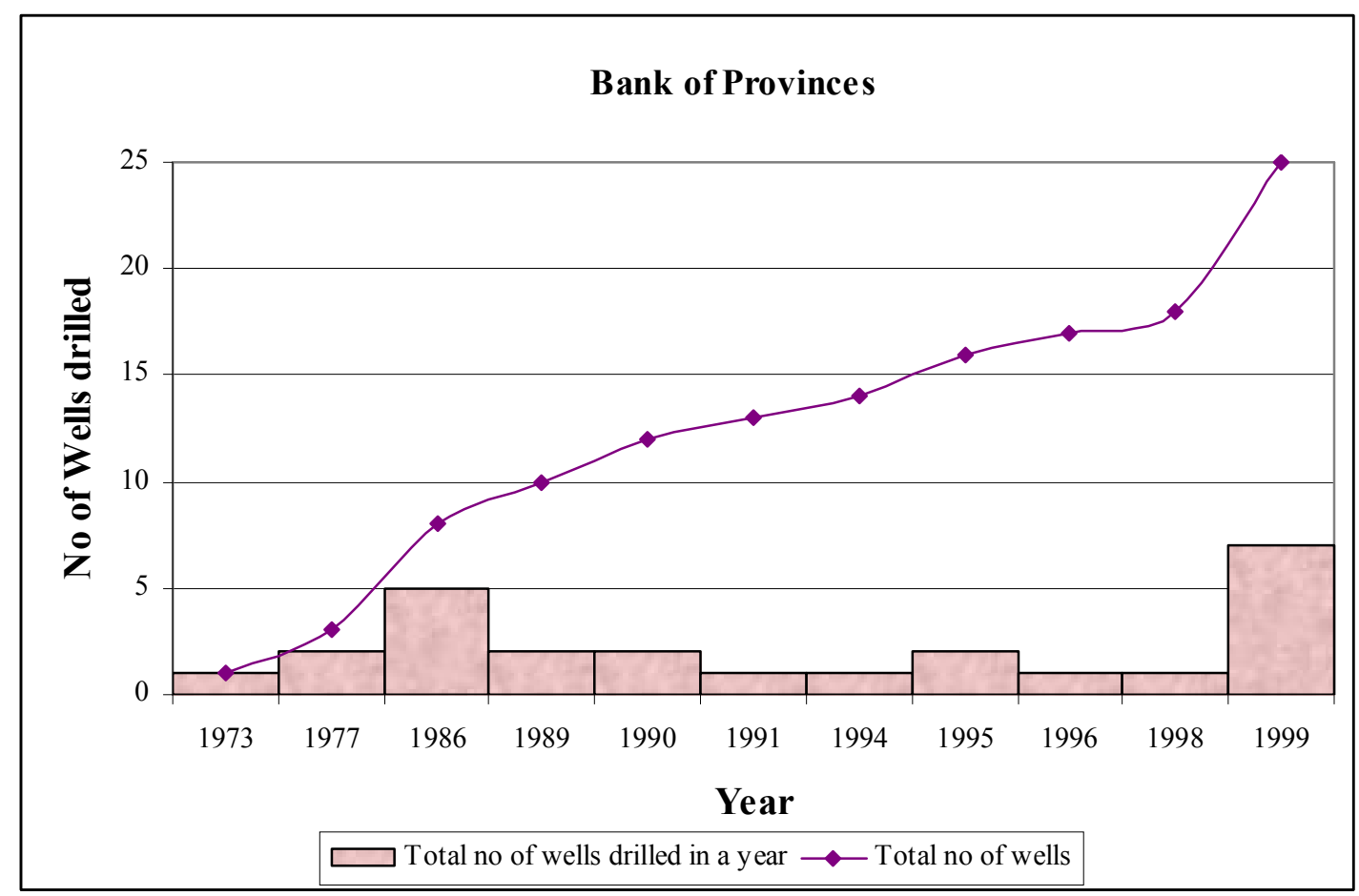

Figure 3.8: Number of wells drilled by Bank of Provinces

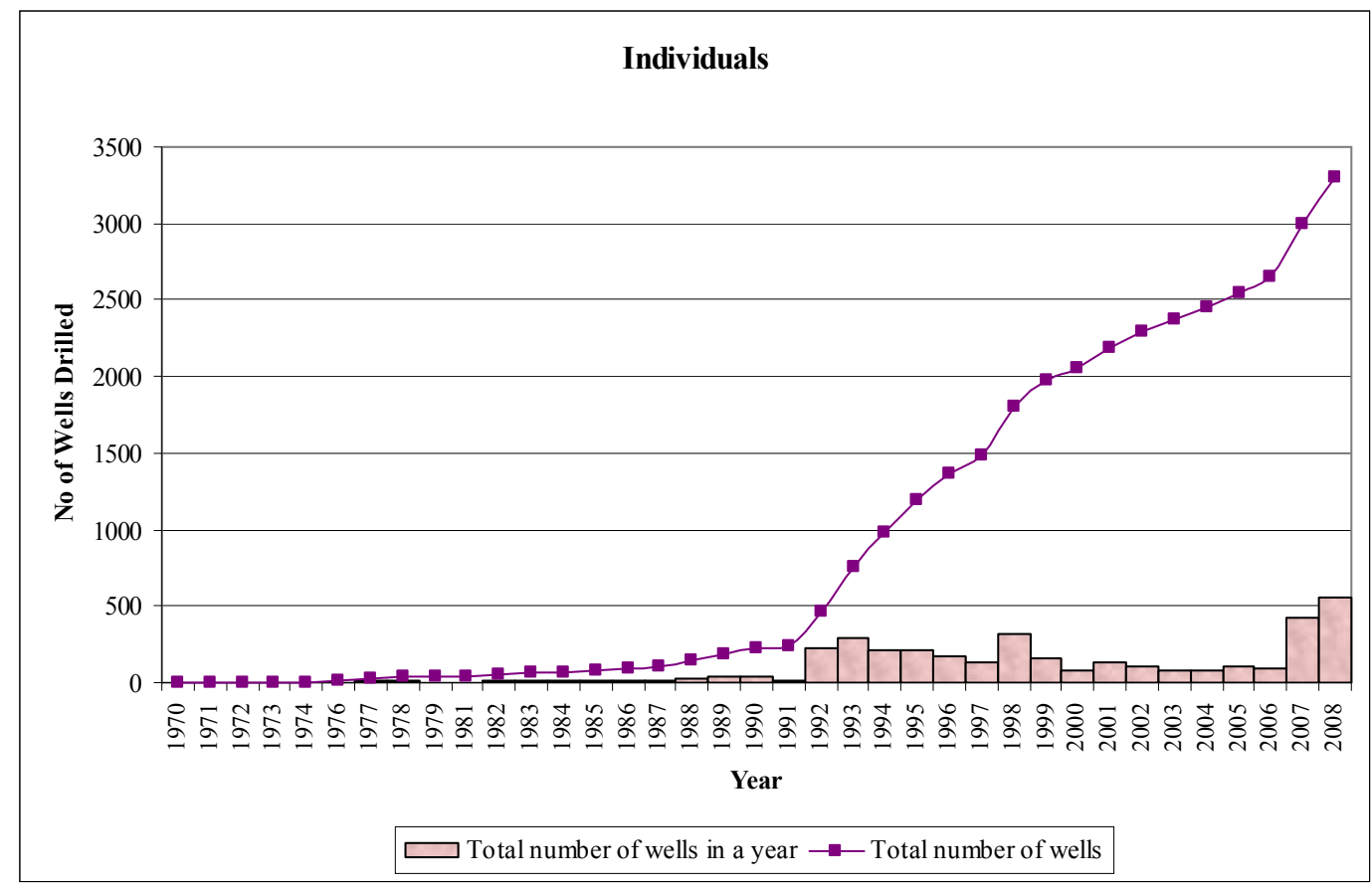

Figure 3.9: Total number of wells drilled by Individuals 


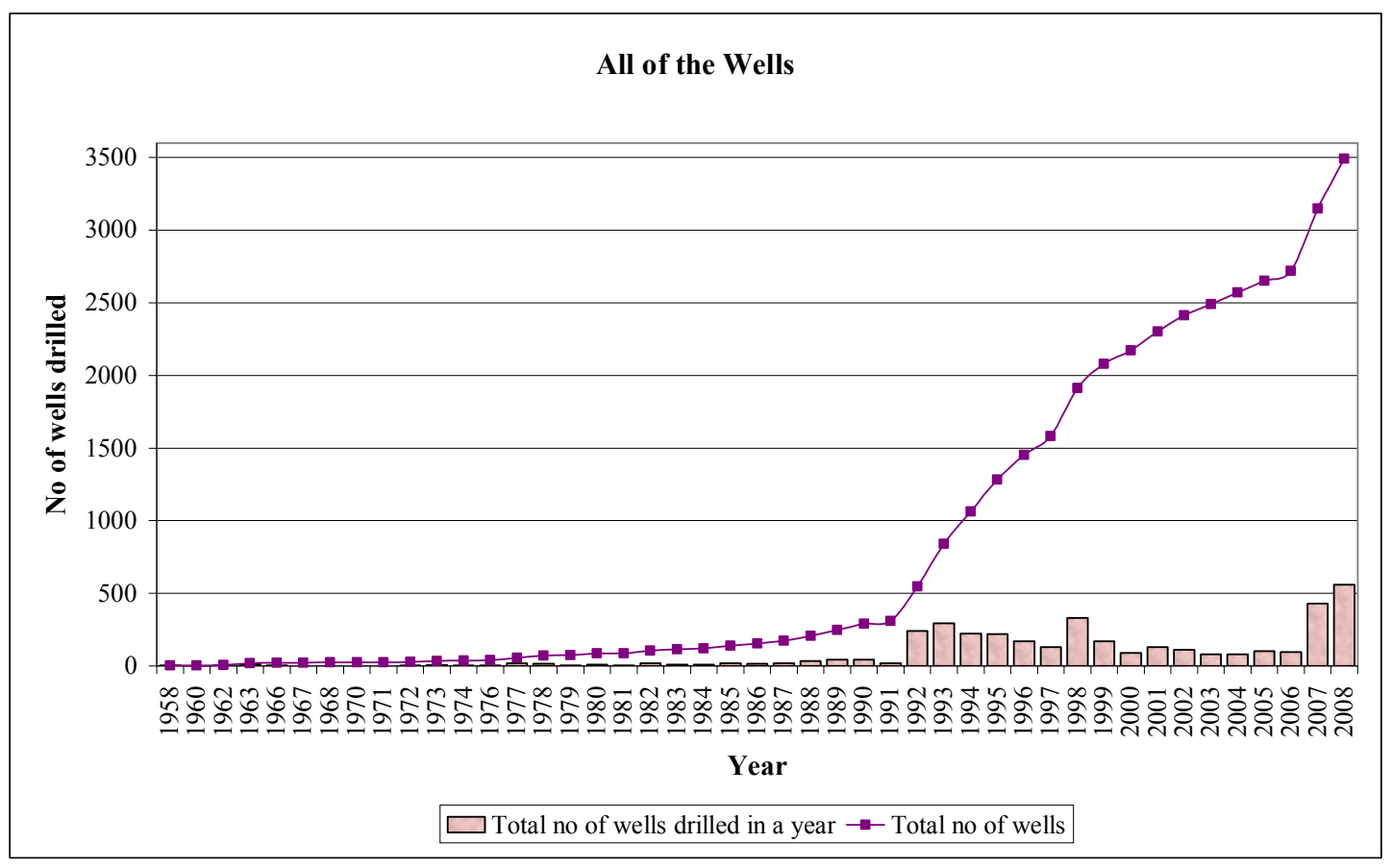

Figure 3.10: Total number of wells drilled in a year

\subsubsection{Irrigational Cooperatives}

Adala irrigation cooperative is the only irrigation cooperative located within the study area. Aim of this irrigation cooperative is to supply additional water for Adala ground surface irrigation. It was planned by DSI in 1977. Adala irrigation cooperative has 6 wells $(25558,25559,25560,25561,25562$ and 25563) as shown in Figure 3.11. Wells, electrification, pumps and irrigational system were completed in 1980. These 6 wells have been operated by DSİ to irrigate nearly 13,022 hectares area since 1980. Total amount of water pumped from these wells is $9.65 \mathrm{hm}^{3} /$ year. 


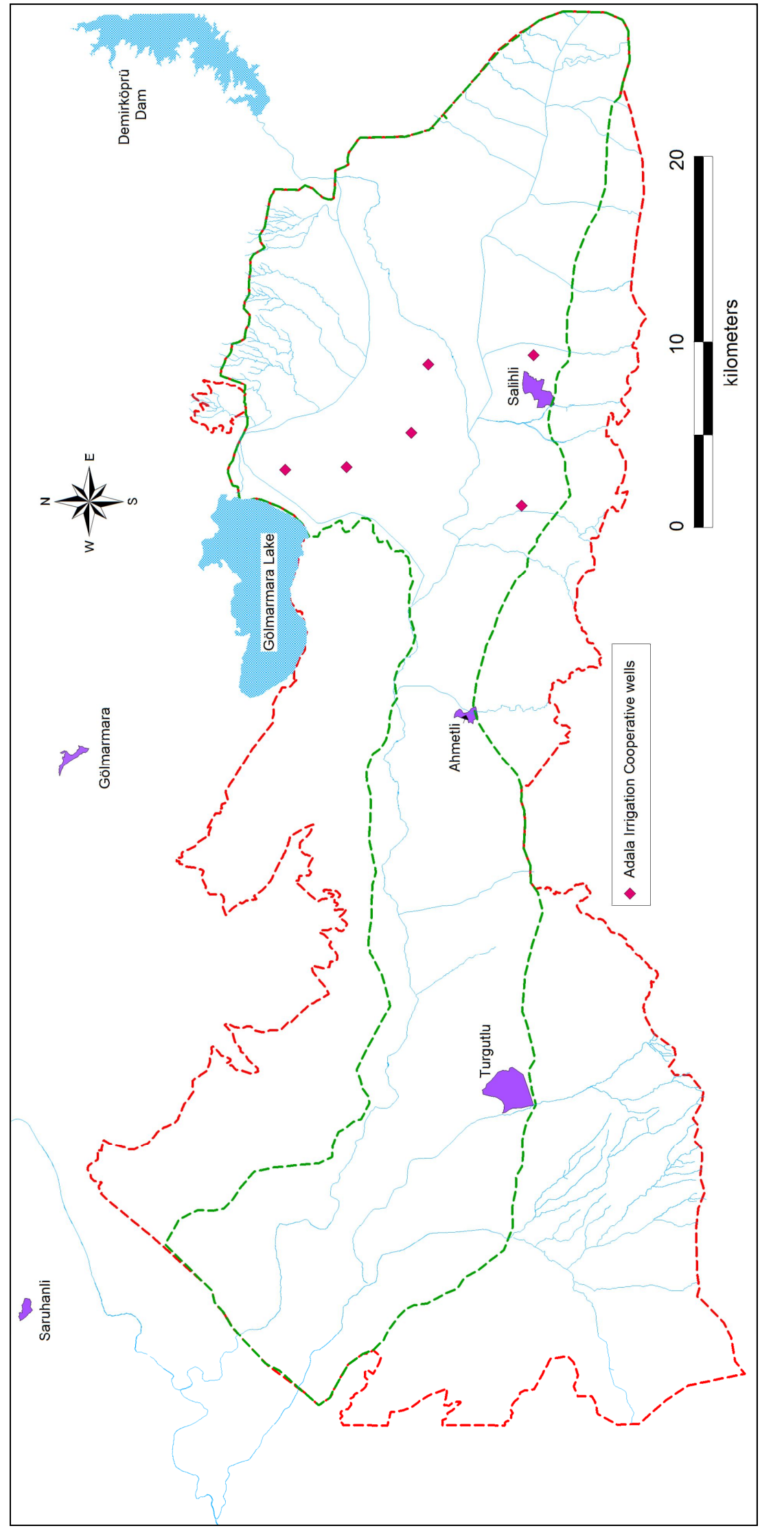

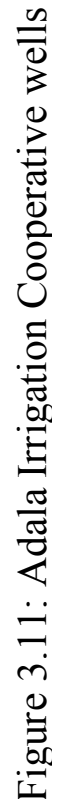




\subsection{Characterization of Groundwater Bearing Units}

The distribution, thickness and depth of groundwater bearing units were determined by the help of well logs drilled by DSİ and Bank of Provinces, results of geophysical resistivity analysis and surface geology.

In the Gediz River Basin, the groundwater bearing units are divided into four hydrogeological units as Paleozoic marble, Mesozoic limestone, Neogene formations, and Quaternary formations. These units are classified by their groundwater bearing capabilities. Hydrogeological map of the Gediz River Basin is given in Figure 3.12.

\subsubsection{Hydrogeologic Classification of Groundwater Bearing Units}

\subsubsection{Paleozoic Marble}

Paleozoic rocks consisting of metamorphic units (schists, gneisess and marbles) form the basement of the Gediz River Basin. Schists and gneisses are impermeable rocks as far as their water bearing properties are considered; hence, they act as impervious units. Paleozoic marble, on the other hand, is one of the formations bearing groundwater. Because it has a limited outcrop in the northern part of the study area and does not have a direct interaction with the Salihli-Turgutlu main aquifer system it is not expected to play an important role in the regional groundwater flow.

\subsubsection{Mesozoic Limestone}

Mesozoic limestone is the other formation bearing groundwater. It has small isolated outcrops in the north and west of the study area. Therefore, like Paleozoic marble, Mesozoic limestone is not expected to play a major role in the regional groundwater flow. 


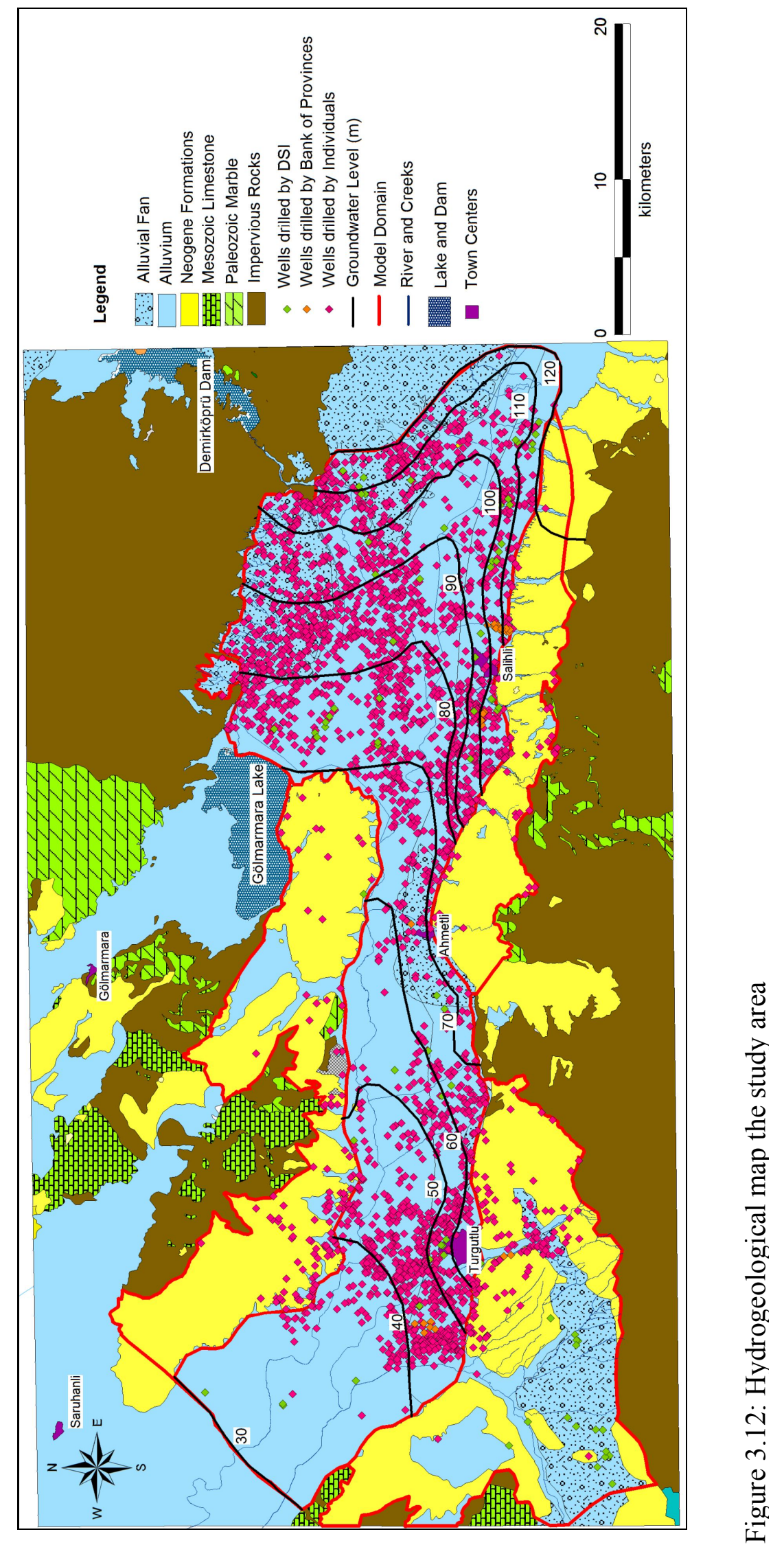




\subsubsection{Neogene Formations}

Neogene aged conglomerates and sandstones form the secondary aquifer in the study area. This unit spreads generally in southern and northern parts of the study area. Because of lack of information, most of the hydrogeological data about Neogene aquifer is not known. There is one well drilled by DSİ, and 150 wells drilled by Individuals into Neogene formations. Yield of the well drilled by DSI is $7.00 \mathrm{~L} / \mathrm{s}$, and specific capacity is $0.43 \mathrm{~L} / \mathrm{s} / \mathrm{m}$. In addition to the DSİ well, from the individuals' wells, there are $4.73 \mathrm{hm}^{3}$ of water pumped annual from Neogene aquifer for drinking and irrigation purposes.

\subsubsection{Quaternary Formations}

Quaternary alluvium and alluvial fan deposits form the principal aquifer in the study area. From Quaternary-Neogene boundary toward Gediz River, thickness of the alluvium increases. From uplands toward Gediz River, lithology of the alluvium changes from rubble, coarse-grained gravel and sand to clay and silt. In this unit, there are many government wells drilled by DSİ and Bank of Provinces. Yields of these wells range in between $0.30 \mathrm{~L} / \mathrm{s}$ and $71.35 \mathrm{~L} / \mathrm{s}$, and the average well yield is 29 $\mathrm{L} / \mathrm{s}$. Specific capacity of these wells range in between $0.03 \mathrm{~L} / \mathrm{s} / \mathrm{m}$ and $88.89 \mathrm{~L} / \mathrm{s} / \mathrm{m}$, and geometric mean of the specific capacity is $3.30 \mathrm{~L} / \mathrm{s} / \mathrm{m}$. DSI performed pumping tests for 17 wells. According to results of these tests, transmissivity of the unit range in between $20 \mathrm{~m}^{2} / \mathrm{d}$ and $7952 \mathrm{~m}^{2} / \mathrm{d}$. Hydraulic conductivity values from these transmissivities are determined in the range between $0.14 \mathrm{~m} / \mathrm{d}$ and $198.80 \mathrm{~m} / \mathrm{d}$. The geometric mean of the hydraulic conductivities was calculated as $4.00 \mathrm{~m} / \mathrm{d}$. There are also 3116 private wells penetrating into Quaternary aquifer. There are $98.27 \mathrm{hm}^{3}$ of water pumped annually from Quaternary aquifer for drinking and irrigation purposes. 


\subsubsection{Hydraulic Properties of Groundwater Bearing Units}

To characterize the aquifer units, besides well yields and specific capacity, determination of aquifer geometry, aquifer parameters and areal distribution of those parameters are important. In the study area, Quaternary and Neogene formations were characterized by examining well logs of DSİ and Bank of Provinces.

\subsubsection{Specific Capacity and Well Yield}

106 wells drilled into two aquifer units; namely, Quaternary formations and Neogene formations. DSİ drilled 81 of these wells and Bank of Provinces drilled 25 of them. There is only one well that penetrates into the Neogene aquifer, and its well yield and specific capacity are $3.7 \mathrm{~L} / \mathrm{s}$ and $0.43 \mathrm{~L} / \mathrm{s} / \mathrm{m}$, respectively. Yield and specific capacity values of the wells in Quaternary aquifer are given in Table 3.5.

Table 3.5: Yield and specific capacity values of the wells in Quaternary aquifer

\begin{tabular}{|c|c|c|c|c|c|}
\hline \multirow{2}{*}{ Well Number } & \multirow{2}{*}{ Institution } & \multicolumn{2}{|c|}{ Coordinate } & \multirow{2}{*}{ Yield (L/s) } & \multirow{2}{*}{ Specific Capacity (L/s/m) } \\
\cline { 3 - 4 } & & Easting & Northing & & \\
\hline $45 / 702$ & Bank of Provinces & 556090 & 4264090 & 51.00 & 25.12 \\
\hline $22(3)$ & Bank of Provinces & 556800 & 4263660 & 69.00 & 5.65 \\
\hline $45 / 716$ & Bank of Provinces & 561040 & 4258930 & 27.60 & 20.91 \\
\hline $45 / 708$ & Bank of Provinces & 561140 & 4258480 & 20.00 & 9.30 \\
\hline $45 / 191$ & Bank of Provinces & 556430 & 4263720 & 40.00 & 9.76 \\
\hline $45 / 192$ & Bank of Provinces & 556690 & 4264120 & 32.00 & 6.40 \\
\hline $45 / 193$ & Bank of Provinces & 556650 & 4264710 & 40.00 & 6.54 \\
\hline $45 / 194$ & Bank of Provinces & 556310 & 4263390 & 30.00 & 15.00 \\
\hline $47(\mathrm{~K} 1)$ & Bank of Provinces & 582460 & 4264930 & 64.30 & 4.02 \\
\hline $46(\mathrm{~A} 2)$ & Bank of Provinces & 601780 & 4259360 & 71.35 & 14.56 \\
\hline $45 / 703(\mathrm{~L} 1)$ & Bank of Provinces & 601380 & 4259070 & 32.50 & 20.31 \\
\hline $45 / 711(\mathrm{~L} 2)$ & Bank of Provinces & 601380 & 4258780 & 42.60 & 5.80 \\
\hline $45 / 2682$ & Bank of Provinces & 601540 & 4259240 & 50.00 & 31.25 \\
\hline $45 / 2703$ & Bank of Provinces & 601340 & 4258590 & 25.00 & 20.83 \\
\hline $45 / 3269$ & Bank of Provinces & 595310 & 4260360 & 25.00 & 19.84 \\
\hline $45 / 200$ & Bank of Provinces & 596160 & 4260200 & 32.00 & 49.23 \\
\hline $45 / 2913$ & Bank of Provinces & 596060 & 4260300 & 30.00 & 60.00 \\
\hline $45 / 4169(\mathrm{~L}-12)$ & Bank of Provinces & 595630 & 4260380 & 45.00 & 1.99 \\
\hline $45 / 4168(\mathrm{~L}-5)$ & Bank of Provinces & 601790 & 4260000 & 6.00 & 1.25 \\
\hline $45 / 4143(\mathrm{~L}-15)$ & Bank of Provinces & 601520 & 4258570 & 40.00 & 24.24 \\
\hline $45 / 4149(\mathrm{~L}-7)$ & Bank of Provinces & 601670 & 4259550 & 40.00 & 10.81 \\
\hline & & & & & \\
\hline
\end{tabular}


Table 3.5: Yield and specific capacity values of the wells in Quaternary aquifer (continued)

\begin{tabular}{|c|c|c|c|c|c|}
\hline 45/4130(L-16) & Bank of Provinces & 601870 & 4259560 & 44.00 & 11.58 \\
\hline 45/4129(L-8) & Bank of Provinces & 601590 & 4259450 & 42.00 & 15.85 \\
\hline 45/4111(L-10) & Bank of Provinces & 601590 & 4258790 & 44.00 & 48.89 \\
\hline 45/4076(L-11) & Bank of Provinces & 601570 & 4259100 & 40.00 & 14.81 \\
\hline B-45/27185 & DSİ & 560850 & 4263750 & 50.00 & 4.11 \\
\hline B-45/27186 & DSİ & 557850 & 4264400 & 30.27 & 1.27 \\
\hline B-45/27191 & DSİ & 552950 & 4268500 & 60.24 & 10.72 \\
\hline B-44/3822-A & DSİ & 574300 & 4263850 & 3.20 & 0.20 \\
\hline B-44/3822-B & DSİ & 573050 & 4266010 & 21.00 & 4.26 \\
\hline B-44/3823-A & DSİ & 561740 & 4262890 & 25.00 & 9.09 \\
\hline B-44/3823-B & DSİ & 561770 & 4263000 & 20.10 & 9.14 \\
\hline B-45/49077 & DSİ & 560150 & 4260975 & 8.00 & 0.39 \\
\hline B-45/7266 & DSİ & 560520 & 4260470 & 9.53 & 0.85 \\
\hline B-45/9537 & DSİ & 561130 & 4262825 & 14.51 & 9.07 \\
\hline 18713-A & DSİ & 571350 & 4262950 & 39.00 & 5.21 \\
\hline 1014 & DSİ & 562120 & 4262680 & 18.00 & 14.40 \\
\hline B-45/26814 & DSİ & 596250 & 4259375 & 30.02 & 8.75 \\
\hline B-45/34879 & DSİ & 596425 & 4259275 & 15.00 & 0.61 \\
\hline B-45/36943 & DSİ & 611100 & 4264950 & 30.00 & 1.23 \\
\hline B-45/36944 & DSİ & 611700 & 4269350 & 50.00 & 6.74 \\
\hline B-45/43658 & DSİ & 614100 & 4256875 & 20.00 & 1.03 \\
\hline B-45/43719 & DSİ & 595500 & 4270475 & 40.00 & 1.12 \\
\hline B-45/43720 & DSİ & 595875 & 4270200 & 40.00 & 1.56 \\
\hline B-45/43721 & DSİ & 607150 & 4267700 & 60.00 & 6.08 \\
\hline B-45/43722 & DSİ & 605040 & 4267250 & 60.00 & 26.43 \\
\hline B-45/44038 & DSİ & 596375 & 4269900 & 40.00 & 3.65 \\
\hline B-45/44039 & DSİ & 594800 & 4271150 & 40.00 & 2.33 \\
\hline B-45/44040 & DSİ & 594525 & 4271025 & 60.00 & 5.24 \\
\hline B-45/46047 & DSİ & 614875 & 4256675 & 10.00 & 0.43 \\
\hline B-45/49005 & DSİ & 596950 & 4259700 & 10.00 & 4.44 \\
\hline B-45/49674 & DSİ & 609525 & 4258550 & 25.00 & 4.30 \\
\hline B-45/49675 & DSİ & 609900 & 4258675 & 30.00 & 8.70 \\
\hline B-45/49676 & DSİ & 609500 & 4259175 & 20.00 & 1.80 \\
\hline B-45/52472 & DSİ & 610700 & 4268300 & 30.00 & 5.03 \\
\hline B-45/52473 & DSİ & 610225 & 4268150 & 30.00 & 0.65 \\
\hline B-45/52474 & DSİ & 610225 & 4267900 & 20.00 & 9.66 \\
\hline B-45/52475 & DSİ & 611275 & 4268000 & 30.00 & 5.67 \\
\hline B-45/54024 & DSİ & 613050 & 4257125 & 40.00 & 2.28 \\
\hline B-45/54025 & DSİ & 613450 & 4257100 & 25.00 & 1.72 \\
\hline B-44/3261-A & DSİ & 613560 & 4258050 & 1.50 & 0.15 \\
\hline B-44/3261-B & DSİ & 613740 & 4258180 & 0.30 & 0.03 \\
\hline B-44/3262 & DSİ & 608020 & 4262800 & 19.65 & 1.03 \\
\hline B-44/3264-B & DSİ & 594000 & 4267090 & 8.00 & 88.89 \\
\hline B-44/3264-A & DSİ & 594200 & 4267090 & 27.50 & 3.58 \\
\hline B-44/3265 & DSİ & 596210 & 4260880 & 2.50 & 0.31 \\
\hline
\end{tabular}


Table 3.5: Yield and specific capacity values of the wells in Quaternary aquifer (continued)

\begin{tabular}{|c|c|c|c|c|c|}
\hline B-45/20289 & DSİ & 599730 & 4260800 & 8.07 & 0.28 \\
\hline B-45/18714-B & DSİ & 605890 & 4259710 & 7.75 & 0.25 \\
\hline B-45/18714-A & DSİ & 605525 & 4259800 & 11.67 & 0.47 \\
\hline B-45/25558 & DSİ & 600750 & 4266100 & 60.24 & 15.69 \\
\hline B-45/25559 & DSİ & 597030 & 4267000 & 60.24 & 4.93 \\
\hline B-45/25560 & DSİ & 595050 & 4273790 & 37.59 & 1.15 \\
\hline B-45/25561 & DSİ & 595190 & 4270500 & 50.46 & 1.93 \\
\hline B-45/25562 & DSİ & 601250 & 4260430 & 57.00 & 4.25 \\
\hline B-45/45249-B & DSİ & 577850 & 4263275 & 4.0 & 0.147 \\
\hline B-35/11190 & DSİ & 547350 & 4252900 & 50.46 & 2.11 \\
\hline B-35/29956 & DSİ & 544850 & 4252275 & 33.05 & 15.02 \\
\hline B-35/29957 & DSİ & 544725 & 4252550 & 33.05 & 9.55 \\
\hline B-35/34733 & DSİ & 549975 & 4254266 & 20.00 & 0.82 \\
\hline B-35/34734 & DSİ & 550575 & 4254834 & 30.00 & 4.71 \\
\hline B-35/47073 & DSİ & 555550 & 4254150 & 25.00 & 1.57 \\
\hline B-35/47074 & DSİ & 555950 & 4254350 & 25.00 & 1.777 \\
\hline B-35/53964 & DSİ & 546250 & 4251950 & 20.00 & 2.07 \\
\hline B-35/53999 & DSİ & 549750 & 4252550 & 30.00 & 11.63 \\
\hline B-35/54000 & DSİ & 549790 & 4253000 & 32.00 & 0.99 \\
\hline B-45/55390 & DSİ & 548750 & 4258600 & 40.00 & 16.88 \\
\hline B-35/29955 & DSİ & 545275 & 4252250 & 40.62 & 11.54 \\
\hline B-35/47037 & DSİ & 555600 & 4254250 & 15.00 & 0.96 \\
\hline B-45/55129 & DSİ & 607025 & 4259100 & 5.00 & 0.10 \\
\hline B-45/55128 & DSİ & 606500 & 4259280 & 20.00 & 0.58 \\
\hline B-45/55127 & DSİ & 605900 & 4259425 & 25.00 & 1.28 \\
\hline 3824-A & DSİ & 551370 & 4273210 & 9.40 & 0.56 \\
\hline 3824-B & DSİ & 551470 & 4273220 & 22.38 & 5.97 \\
\hline B-45/27196 & DSİ & 597000 & 4259750 & 26.00 & 4.92 \\
\hline B-45/25563 & DSİ & 593120 & 4261090 & 40.62 & 1.18 \\
\hline 18713-B & DSİ & 572060 & 4262350 & 40.00 & 1.52 \\
\hline B-35/33286 & DSİ & 550300 & 4257400 & 10.88 & 1.50 \\
\hline B-35/57396 & DSİ & 548075 & 4252125 & 20.00 & 3.60 \\
\hline B-35/57700 & DSİ & 548000 & 4252400 & 25.00 & 13.23 \\
\hline B-35/57397 & DSİ & 548350 & 4252350 & 10.00 & 0.22 \\
\hline B-35/55415 & DSİ & 555275 & 4254275 & 25.00 & 1.09 \\
\hline B-35/56176 & DSİ & 557025 & 4255925 & 15.00 & 0.55 \\
\hline
\end{tabular}

Maximum and minimum specific capacity is observed as $88.89 \mathrm{~L} / \mathrm{s} / \mathrm{m}$ and $0.03 \mathrm{~L} / \mathrm{s} / \mathrm{m}$ for wells drilled in Quaternary aquifer. Geometric mean of the specific capacity is $3.30 \mathrm{~L} / \mathrm{s} / \mathrm{m}$. The large spread between values is attributed to lithological changes (from very coarse sediments to fine sediments in alluvium) and well construction 
practices. Maximum yield of the Quaternary aquifer is $71.35 \mathrm{~L} / \mathrm{s}$ (Table 3.5). Average specific yield was calculated as $29.0 \mathrm{~L} / \mathrm{s}$.

\subsubsection{Hydraulic Conductivity}

Only 15 wells drilled in the study area by DSİ have pumping test results. All 15 wells were drilled into Quaternary aquifer. Using transmissivities obtained from these tests, hydraulic conductivities were calculated (Table 3.6). Geometric mean of them gives the hydraulic conductivity of Quaternary aquifer as $4 \mathrm{~m} / \mathrm{d}$. Because of lack of information, hydraulic conductivities of alluvial fans and Neogene aquifer were not calculated.

Table 3.6: Calculated hydraulic conductivity values of Quaternary aquifer

\begin{tabular}{|c|c|c|c|}
\hline \multirow{2}{*}{ Well No } & \multicolumn{2}{|c|}{ Coordinates } & \multirow{2}{*}{$\begin{array}{c}\text { Hydraulic } \\
\text { Conductivity (m/d) }\end{array}$} \\
\cline { 2 - 3 } & Easting & Northing & 4.39 \\
\hline B-45/27185 & 560850 & 4263750 & 1.47 \\
\hline B-45/27186 & 557850 & 4264400 & 29.81 \\
\hline B-45/27191 & 552950 & 4268500 & 198.80 \\
\hline B-45/26814 & 596250 & 4259375 & 1.22 \\
\hline B-44/3261-A & 613560 & 4258050 & 0.65 \\
\hline B-45/20289 & 599730 & 4260800 & 0.50 \\
\hline B-45/18714-B & 605890 & 4259710 & 0.50 \\
\hline B-45/18714-A & 605525 & 4259800 & 35.63 \\
\hline B-45/25558 & 600750 & 4266100 & 11.85 \\
\hline B-45/25559 & 597030 & 4267000 & 2.14 \\
\hline B-45/25560 & 595050 & 4273790 & 1.72 \\
\hline B-45/25561 & 595190 & 4270500 & 0.97 \\
\hline B-45/25562 & 601250 & 4260430 & 15.20 \\
\hline B-45/27196 & 597000 & 4259750 & 6.02 \\
\hline B-45/25563 & 593120 & 4261090 & \\
\hline
\end{tabular}

\subsubsection{Areal Extent, Depth and Thickness of Ground water Bearing Units}

The principal aquifer in the Gediz River Basin is Quaternary aquifer including alluvium and alluvial fan deposits. Neogene aquifer is the secondary aquifer. Although Mesozoic limestone and Paleozoic marble are good aquifers for some parts 
of the Gediz River Basin, their interaction with two units and their regional extent is negligible in the studied portion of the basin.

According to results of detailed analysis on aquifer characteristics, hydrogeological system in the study area was defined conceptually. There are two separate aquifers in the study area as Quaternary aquifer and Neogene aquifer. Quaternary aquifer includes alluvium and alluvial fan deposits and Neogene aquifer includes both Pliocene and Miocene rocks because of their similar hydraulic properties. Extent and boundaries of both aquifer units are given in Figure 3.13.

\subsubsection{Aquifer Geometry}

In order to get ground surface elevation of the study area, 24 digitized 1/25,000 scaled topographic maps were used, and Digital Elevation Model (DEM) with 12.5 $\mathrm{m}$ grid size has been developed using MapInfo 8.5 Software as presented in Figure 3.14. For the bottom elevation map of the Quaternary aquifer, the information obtained from well logs of DSİ and Bank of Provinces, and data and cross-sections in geophysical investigation reports of DSİ were interpolated by the triangulation with smoothing method. Locations of the wells and the geophysical resistivity points utilized to develop the bottom elevation map of the Quaternary aquifer are given in Figure 3.15. Bottom elevation map of Quaternary aquifer is illustrated in Figure 3.16. This map shows that the Quaternary aquifer becomes thicker from hillside toward Gediz River. Because of lack of information about southwestern part of the Quaternary aquifer, while preparing the bottom elevation and groundwater elevation maps of the study area, southwestern part was excluded. Neogene aquifer is overlain by Quaternary aquifer. Therefore, top of the Neogene aquifer is same as the bottom elevation map of Quaternary aquifer in the locations where these two units overlap. Topography forms the upper boundary of the Neogene aquifer where it outcrops. Because of the lack of information about the Neogene units, bottom and groundwater elevation maps of Neogene units were not prepared. 


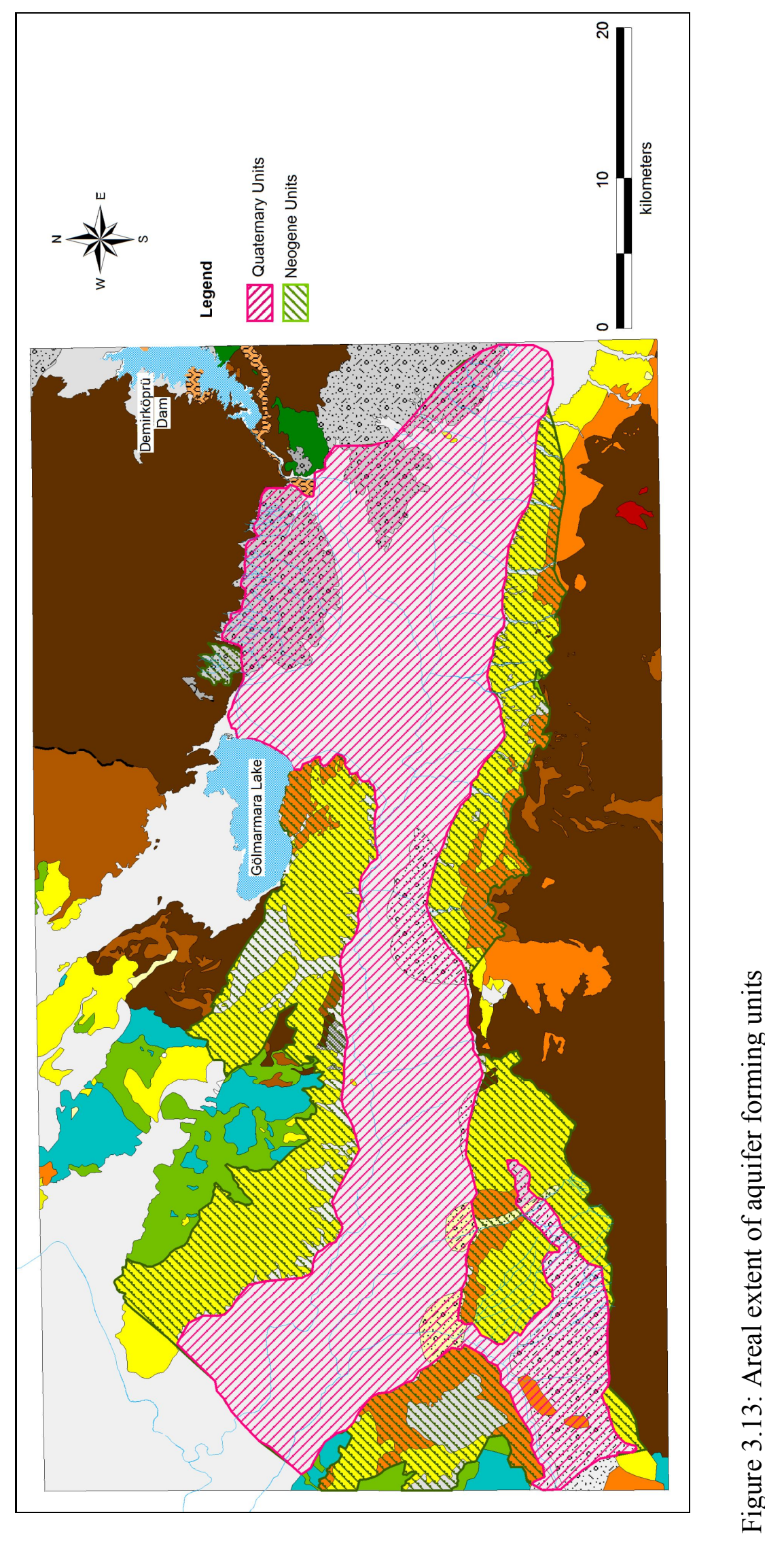




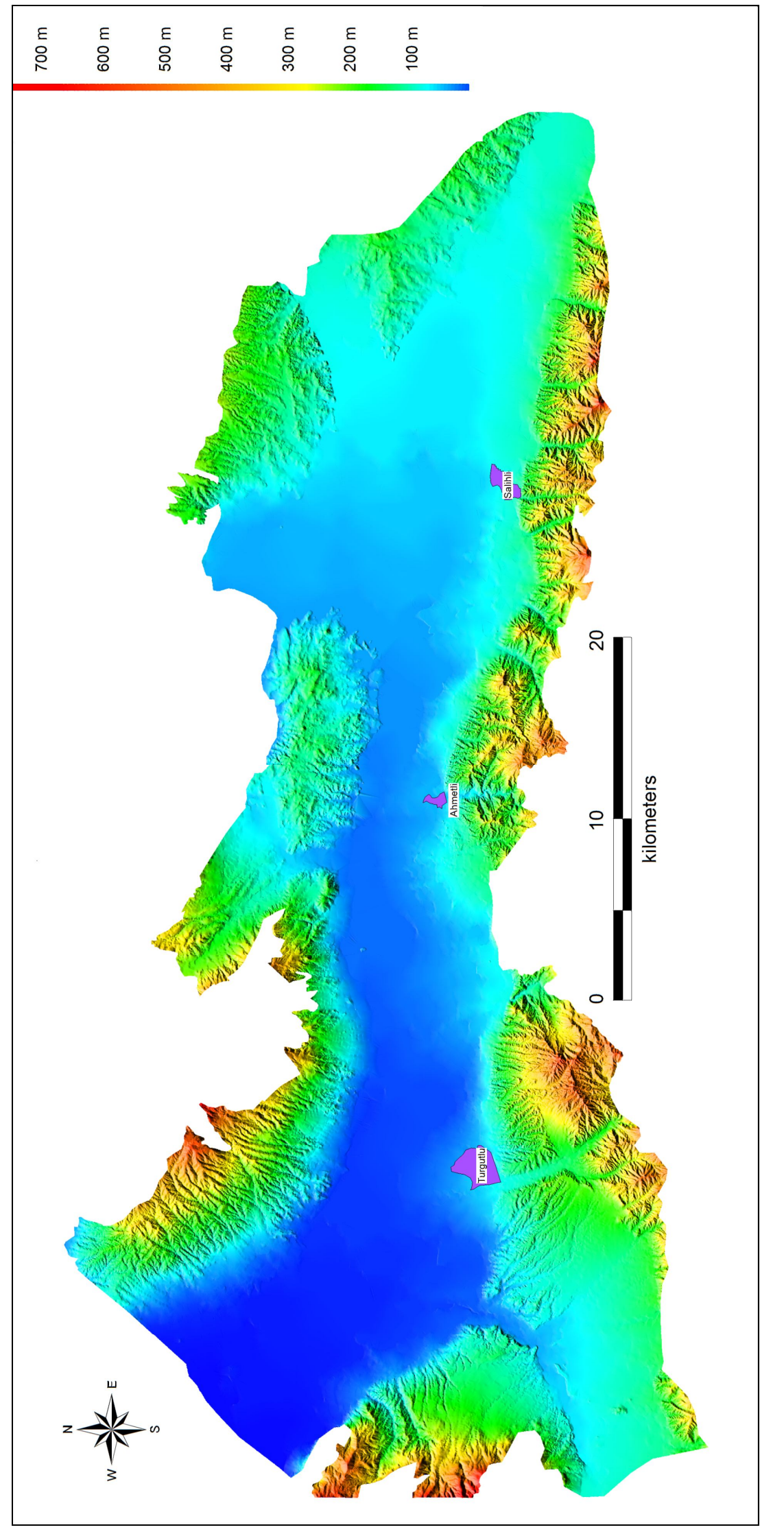

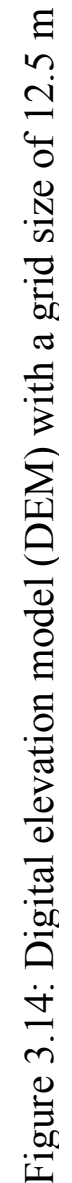




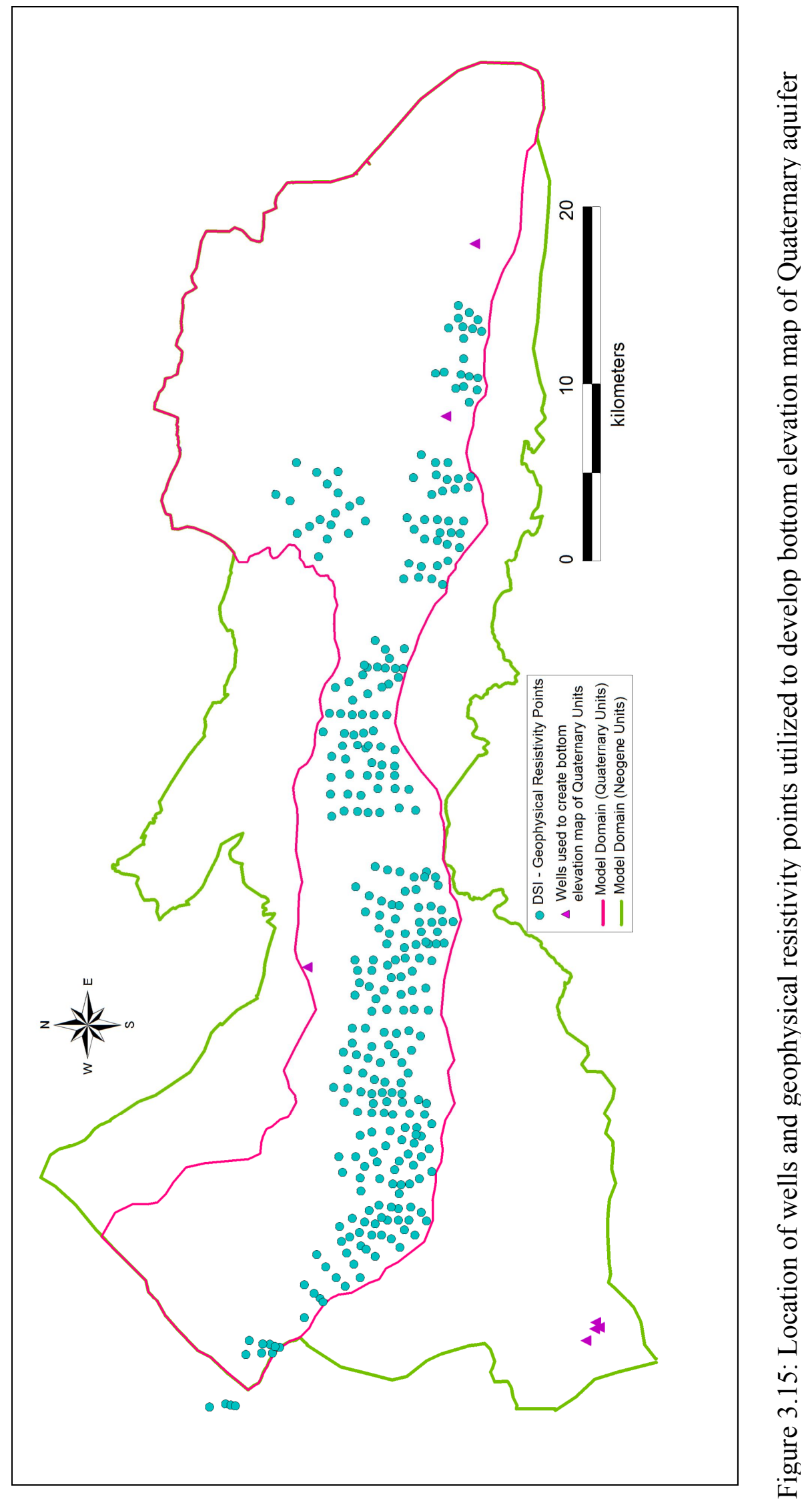




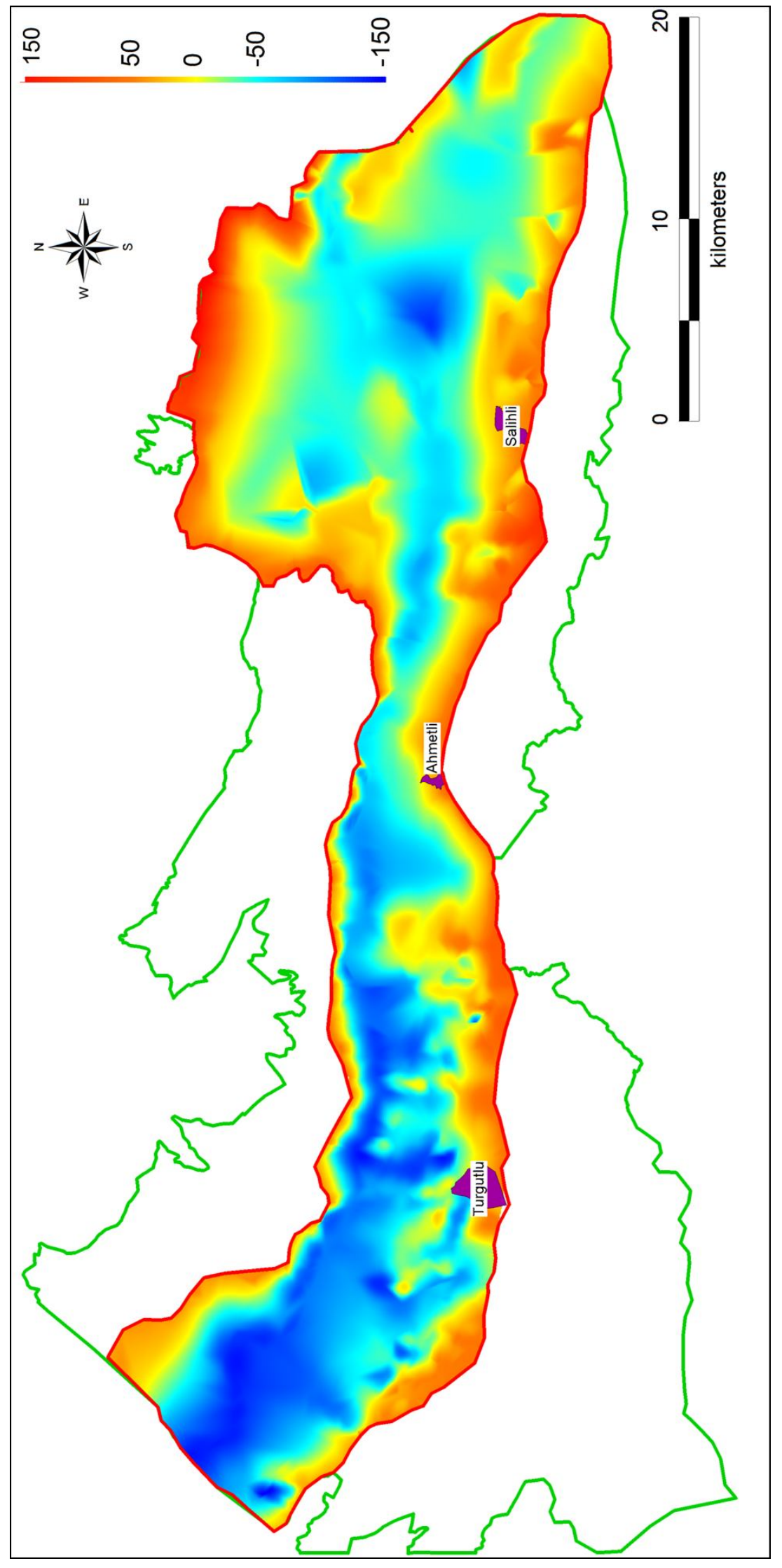

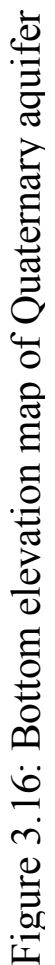




\subsubsection{Areal Distribution of Groundwater Levels}

Areal distribution of groundwater levels is also determined to characterize aquifer geometry. Groundwater elevation map of the Quaternary aquifer has been developed by interpolating the static groundwater elevations measured at wells drilled by DSI and Bank of Provinces (Figure 3.17), and water level at Gölmarmara Lake and the Gediz River. The interpolation method is the triangulation with smoothing. The groundwater elevation map is represented in Figure 3.17. Groundwater elevations in the Quaternary aquifer range from $120 \mathrm{~m}$ in the east to $30 \mathrm{~m}$ in the west as seen in Figure 3.17. In eastern part of the study area, Gediz River displays gaining characteristics, but in western part it is neither gaining nor losing. Hydraulic gradient on the southeastern part of the river is greater than the one on the northeastern part. From east to west, hydraulic gradient becomes smaller. Because of lack of information, a regional groundwater elevation map for the Neogene aquifer was not constructed.

\subsubsection{Temporal Changes in Groundwater Levels}

Temporal changes in groundwater levels are monitored by DSİ in 2 wells since 1982. Both of these wells penetrate into alluvium (Quaternary aquifer). Information about these monitoring wells such as formation, monitoring period and coordinates are summarized in Table 3.7. Locations of the monitoring wells are shown in Figure 3.18. Graphical representation of the temporal changes in groundwater levels in these wells are given in Figure 3.19. Water levels in these two wells fluctuate seasonally in response to irrigation pumping and recharge from precipitation. In addition, the general trend of the water levels are in agreement with the wet and dry periods observed in the basin as it can be depicted by comparing the water levels with the cumulative deviation graphs for Turgutlu and Salihli Stations (Figures 2.4 and 2.7). 


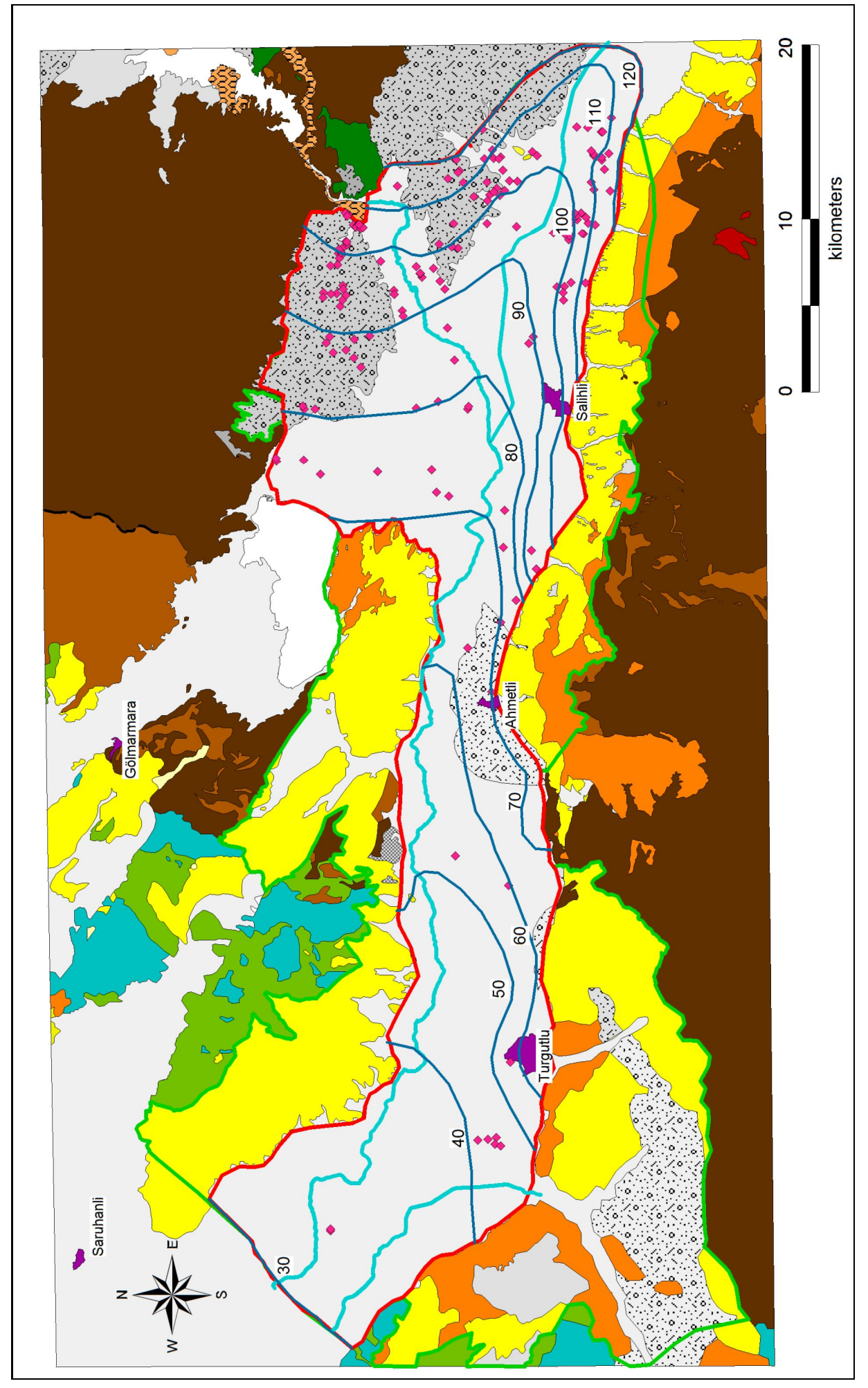

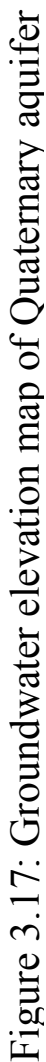




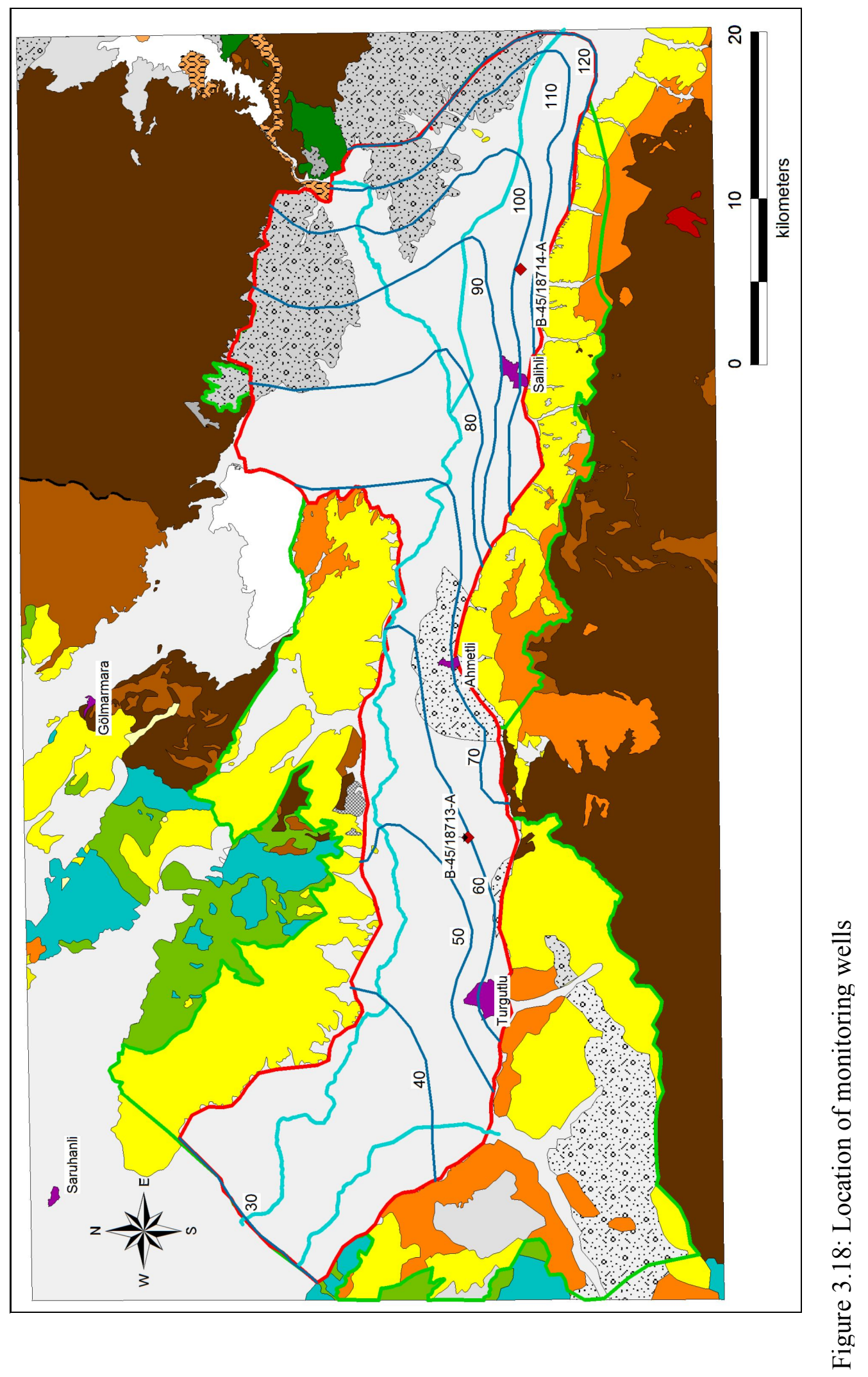


Table 3.7: Information about monitoring wells

\begin{tabular}{|c|c|c|c|c|}
\hline \multirow{2}{*}{ Well Number } & \multicolumn{2}{|c|}{ Coordinates } & \multirow{2}{*}{ Formation } & $\begin{array}{c}\text { Monitoring } \\
\text { Period }\end{array}$ \\
\cline { 2 - 3 } & Easting & Northing & & $1982-2009$ \\
\hline B-45/18713-A & 571350 & 4262950 & Alluvium & $1982-2009$ \\
\hline B-45/18714-A & 605525 & 4259800 & Alluvium & $1982-5$ \\
\hline
\end{tabular}

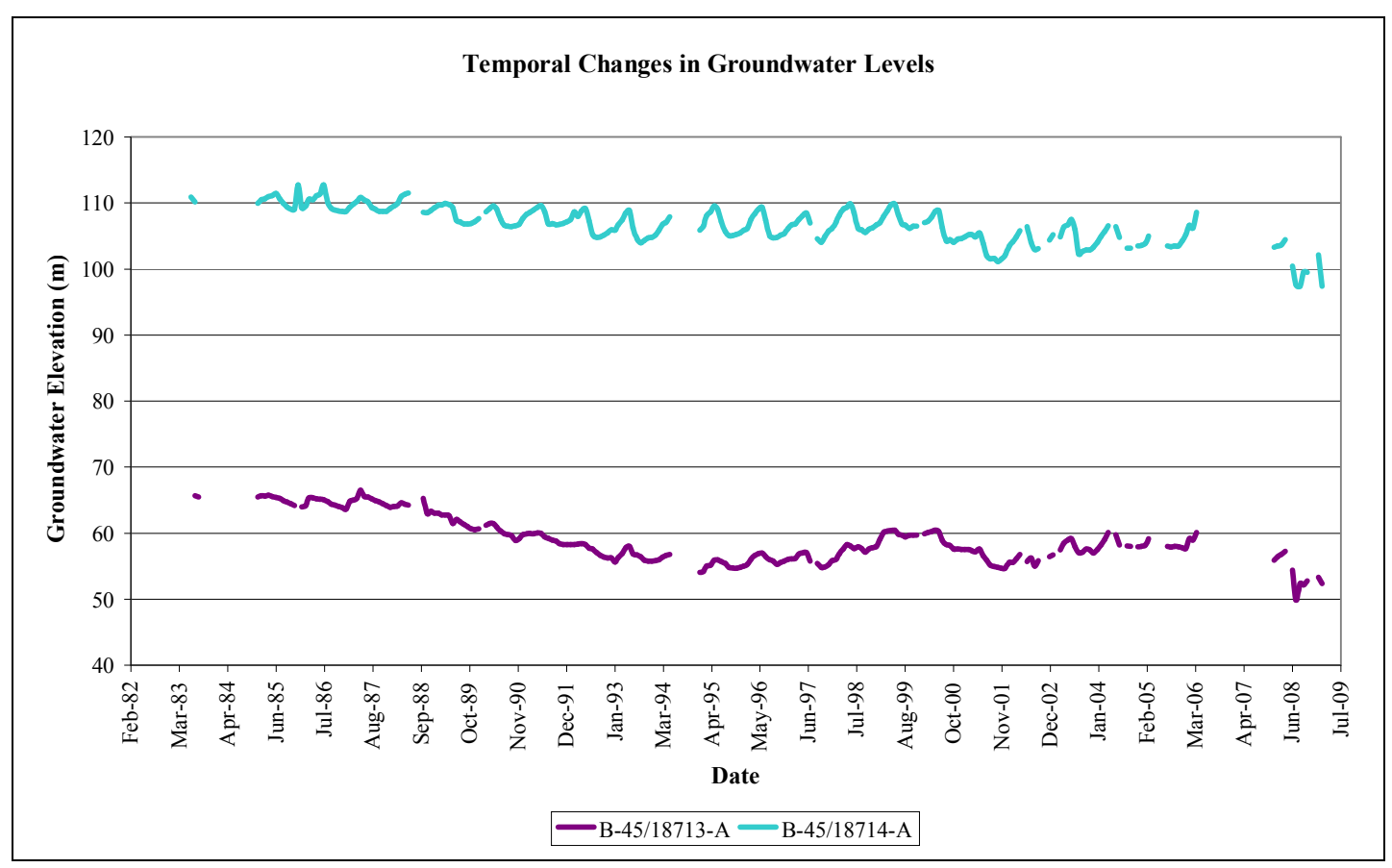

Figure 3.19: Temporal changes in groundwater levels

\subsubsection{Saturated Thickness}

Saturated thickness map was prepared for Quaternary aquifer by subtracting bottom elevation map of the Quaternary aquifer from groundwater level map of Quaternary aquifer in MapInfo 8.5 Software (Figure 3.20). Thickness ranges in between $50 \mathrm{~m}$ to $180 \mathrm{~m}$. Aquifer is thicker near the Gediz River, and becomes thinner toward the uplands. 


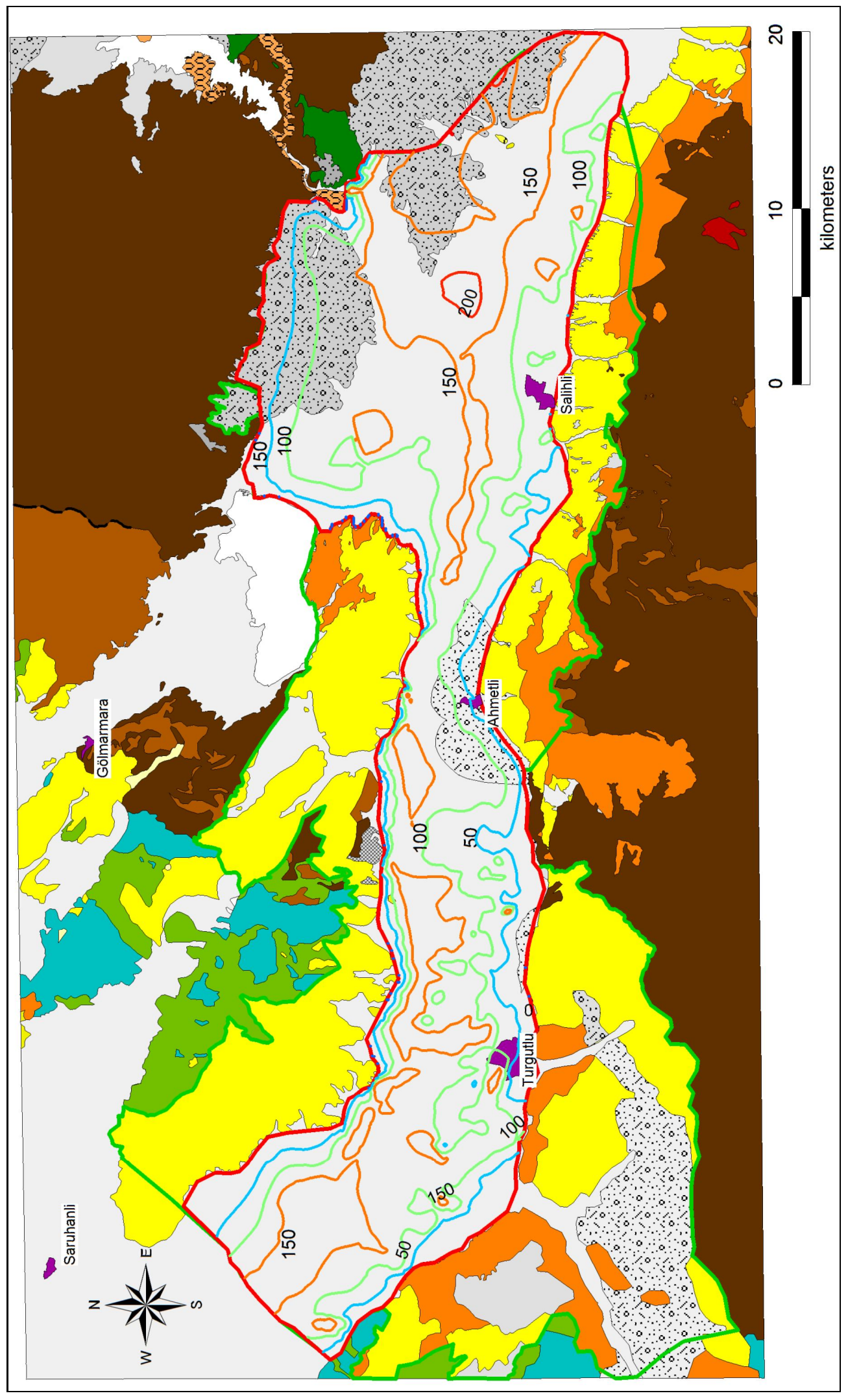

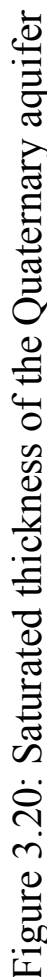




\section{CHAPTER 4}

\section{ALTERNATIVE SOURCES OF WATER SUPPLY}

\subsection{Introduction}

Various sources of water supply are considered to meet the mine water requirements. These sources consist of (1) surface water, (2) groundwater, and (3) treated waste water. These alternative sources of water supply are considered to meet $135 \mathrm{~L} / \mathrm{s}$ water requirement of the mine for 15 years.

\subsection{Alternative I: Surface Water}

First alternative for the source of process water is the surface water. Gediz River is the most important surface water source. The water supply to the mine site is planned to be sourced through a combination of surface water from the Gediz River and groundwater supply from the Quaternary or the Neogene aquifer located within the study area as mentioned in Environmental Impacts Assessment Report - Çaldağ Project by ENCON (2005). In fact, the surface water abstraction structure and the associated pipeline system have been already constructed. However, the recent drought has caused local farmers and governmental officers to raise a concern on using the Gediz River to meet the water supply needs. Hence, it became essential to conduct low flow analyses of the Gediz River to assess the long-term availability of the river water supply. Four types of analyses were carried out: (1) Flow frequency histograms and flow duration frequency curve for daily flows, (2) one-day, 7-days, 15-days, 30-days and 60-days low flow volume frequency curves, (3) low flow 
duration frequency curve for a specified discharge value, and (4) longest low flow duration frequency curve for a specified discharge value. In conducting this analysis, the daily flow data for a period of 13 years at Urganli Station (No. 533) is used because it is closer to the surface water abstraction point (Figure 3.2). Period of data available for Urganlı station is coincided with the dry period mentioned in Section 2.2.3. Although Station No. 518 has a longer period of data, its data reflects the combined flows derived from a number of tributaries which join the Gediz River downstream of the mine site

\subsubsection{Flow Frequency Histogram and Flow Duration Frequency Curve for Daily Flows}

Flow frequency histogram for mean daily flows for a period of 13 years at Urganl1 (No. 533) station is shown in Figure 4.1. This histogram shows that about one-fourth of the time discharge is smaller than $2 \mathrm{~m}^{3} / \mathrm{s}$, about one-fourth of the time it is between $2 \mathrm{~m}^{3} / \mathrm{s}$ and $5 \mathrm{~m}^{3} / \mathrm{s}$, and it is greater than $5 \mathrm{~m}^{3} / \mathrm{s}$ in the remaining one-half.

Flow duration frequency curves are one of the most informative means of displaying the complete range of river discharges, from low flows to flood events (Smakhtin, 2001). Flow duration curves are cumulative frequency distributions that show the percent of time that a specified discharge is equaled or exceeded during the entire period of record. Flow duration frequency curve for mean daily flows for a period of 13 years at Urganlı station is shown in Figure 4.2. The exceedence probability $Q_{95}$ is one of the most commonly used index for indicating extreme low flow conditions, a minimum flow to protect the river, licensing of surface water extractions, and effluent discharge limits assessments (Pyrce, 2004). The exceedence probability, $\mathrm{Q}_{95}$, can be interpreted as the flow discharge which can be expected to be exceeded $95 \%$ of the time. The flow duration frequency curve given in Figure 4.2 show that the $\mathrm{Q}_{95}$ discharge level is $0.50 \mathrm{~m}^{3} / \mathrm{s}$. Thus, at Urganl1 station the Gediz River flow rates exceeded $0.5 \mathrm{~m}^{3} / \mathrm{s}$ at $95 \%$ of the time. 


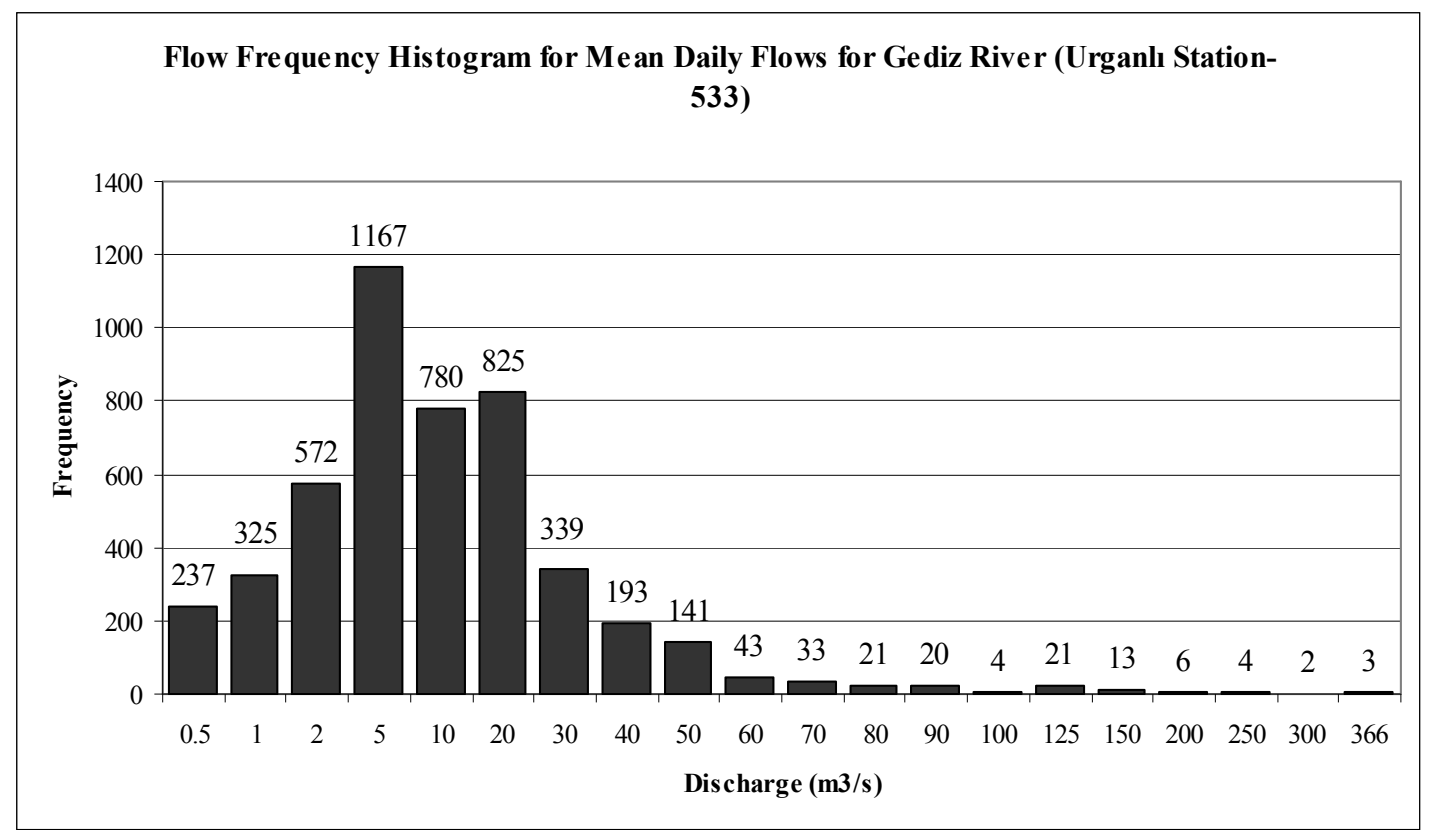

Figure 4.1: Daily flow frequency histogram for the Gediz River at Urganl1 (No. 533) station

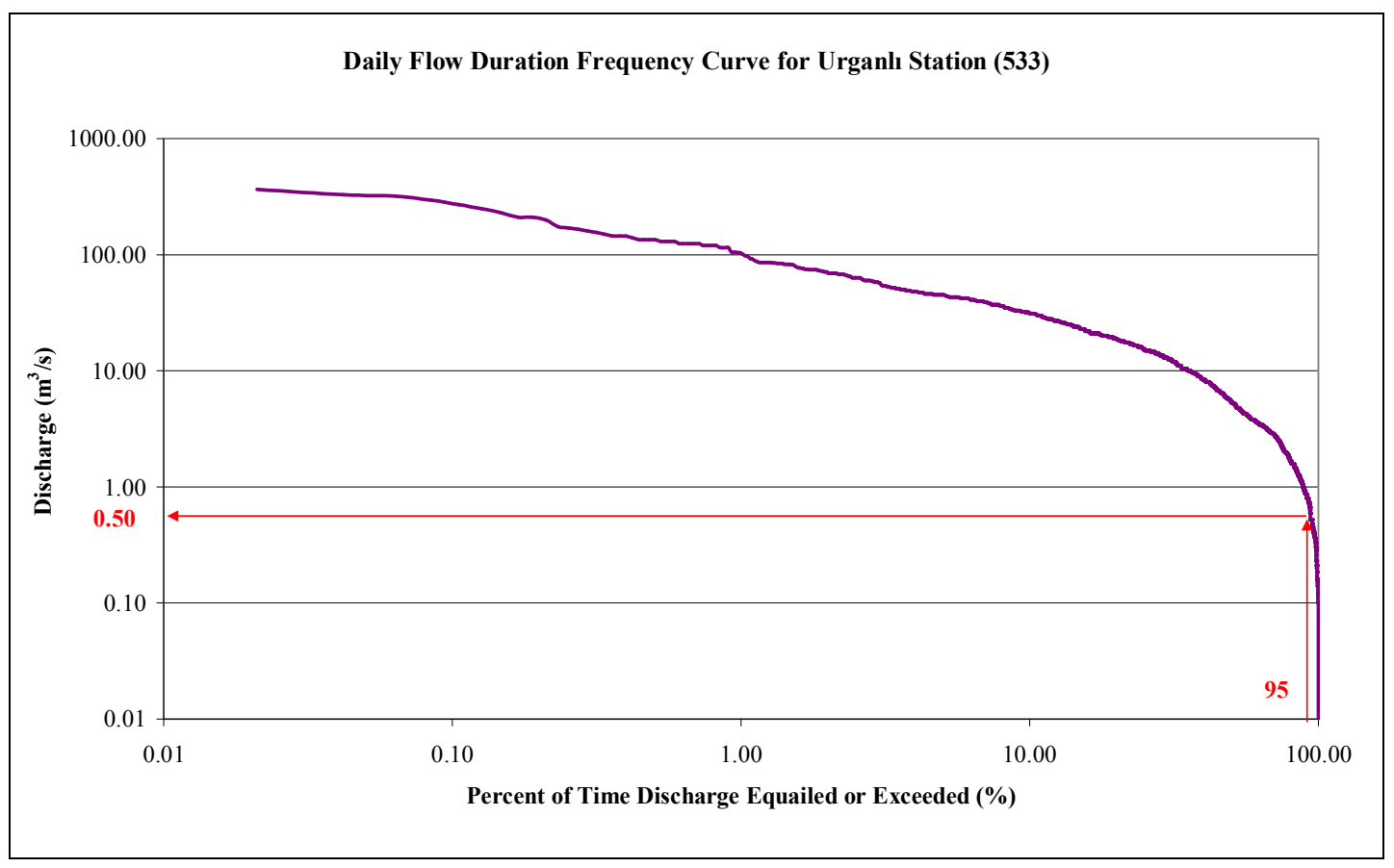

Figure 4.2: Daily flow duration frequency curve for the Gediz River at Urganl1 (No. 533) station 


\subsubsection{Low Flow Frequency Curves}

Low flow volume $(\mathrm{V})$ is defined as the minimum volume for a given time interval $\mathrm{t}$ within a specified time unit period $\left(T_{u}\right)$. Time unit period, $T_{u}$, consists of a year of 365 or 366 days (Figure 4.3). The time intervals (t) selected for the analyses are 1day, 7-days, 15-days, 30-days and 60-days. Low flow volumes are expressed as the mean discharge for the time interval $t$ or equal to $\mathrm{V} / \mathrm{t}$. The frequency curves of low flow volumes for time intervals of 1-day, 7-days, 15-days, 30-days, and 60-days for the Gediz River at Urganlı station are shown in Figure 4.4. For a specified time interval, the minimum volume of water was determined for each of the 13 years of data and exceedence probabilities were calculated. The low flow frequency curves given in Figure 4.4 illustrate, for example, the probability that the one-day low flow volume will be greater than $0.865 \mathrm{~m}^{3} / \mathrm{sec} /$ day is $50 \%$.

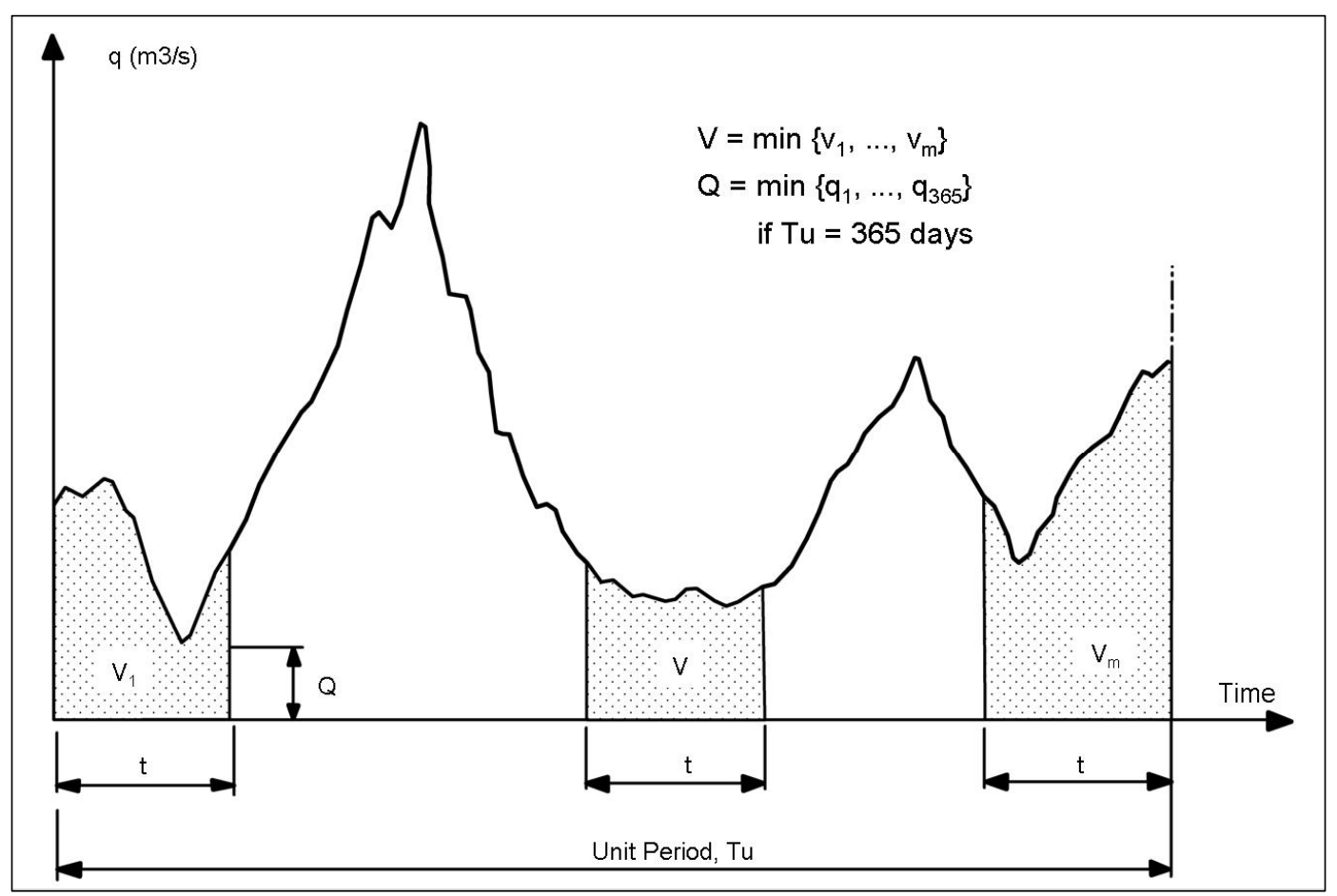

Figure 4.3: Graphical representation of the definition of low flow volume and low flow discharge (After Salas, 1980) 


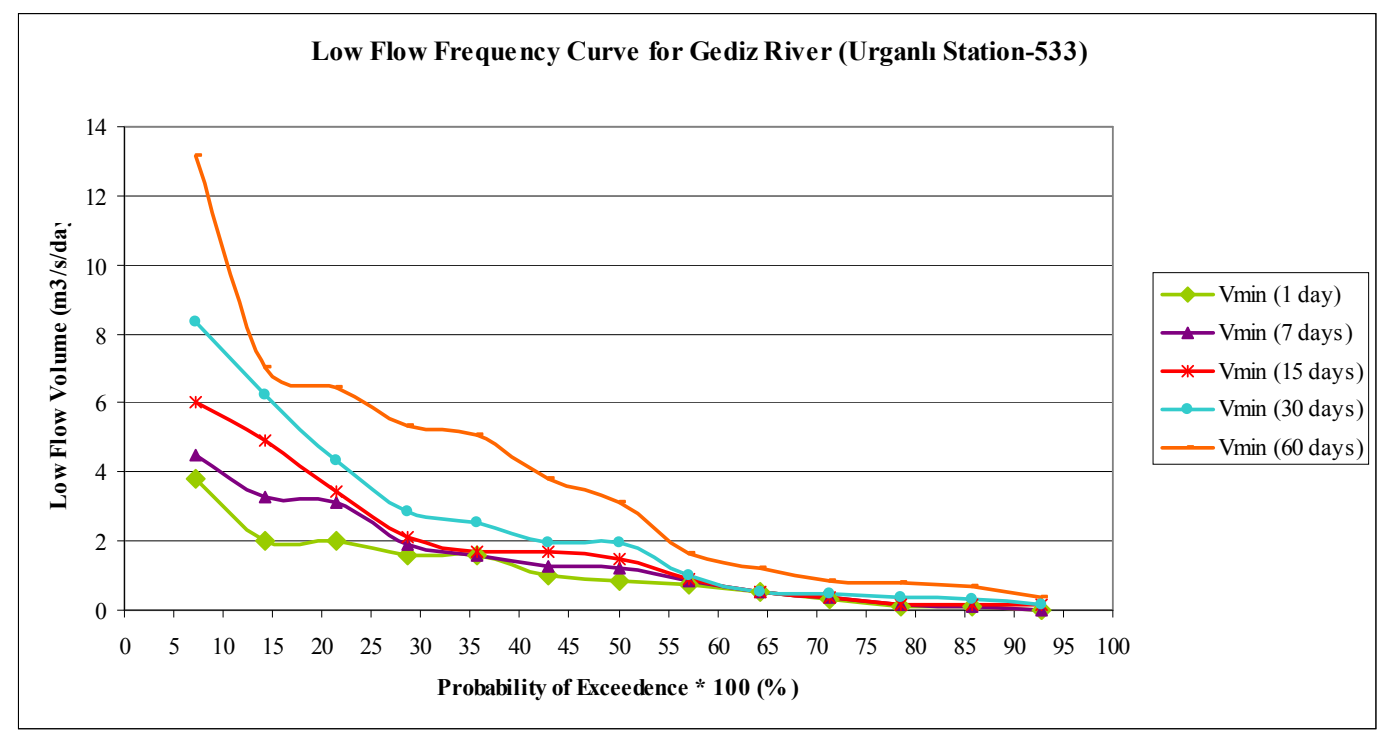

Figure 4.4: Low flow frequency curves for the Gediz River at Urganlı (No. 533) station

\subsubsection{Low Flow Duration Frequency Curves}

Low flow duration (D) is defined as the total time for which flows are smaller than a specified discharge $\left(\mathrm{q}_{\mathrm{o}}\right)$ during a time unit period $\mathrm{T}_{\mathrm{u}}$ (Figure 4.5). If for a given $\mathrm{q}_{\mathrm{o}}$ and $T_{u}$ there are $k$ times in which the flows fall below $q_{o}$ with corresponding durations $d_{1}, d_{2}, \ldots ., d_{k}$, then the low flow duration is $D=d_{1}+d_{2}+\ldots . .+d_{k}$. The mean daily discharges for the Gediz River at Urganlı station were used to find the series of low flow durations. The specified discharge values $\left(\mathrm{q}_{\mathrm{o}}\right)$ used in the analyses corresponds to $\mathrm{Q}_{95}$ discharge value $\left(0.5 \mathrm{~m}^{3} / \mathrm{s}\right)$ estimated for the Gediz River as discussed in Section 4.2.1. Based on a time unit period, $\mathrm{T}_{\mathrm{u}}=1$ year and a specified discharge level, $\mathrm{q}_{\mathrm{o}}=0.5 \mathrm{~m}^{3} / \mathrm{sec}$, total low flow durations for each year was calculated and exceedence probabilities were determined. Low flow duration frequency curve corresponding to $\mathrm{q}_{\mathrm{o}}=0.5 \mathrm{~m}^{3} / \mathrm{sec}$ for the Gediz River is shown in Figure 4.6. Thus, the probability that the total duration in which flows are lower than $0.5 \mathrm{~m}^{3} / \mathrm{sec}$ being more than 30 days is about $25 \%$. 


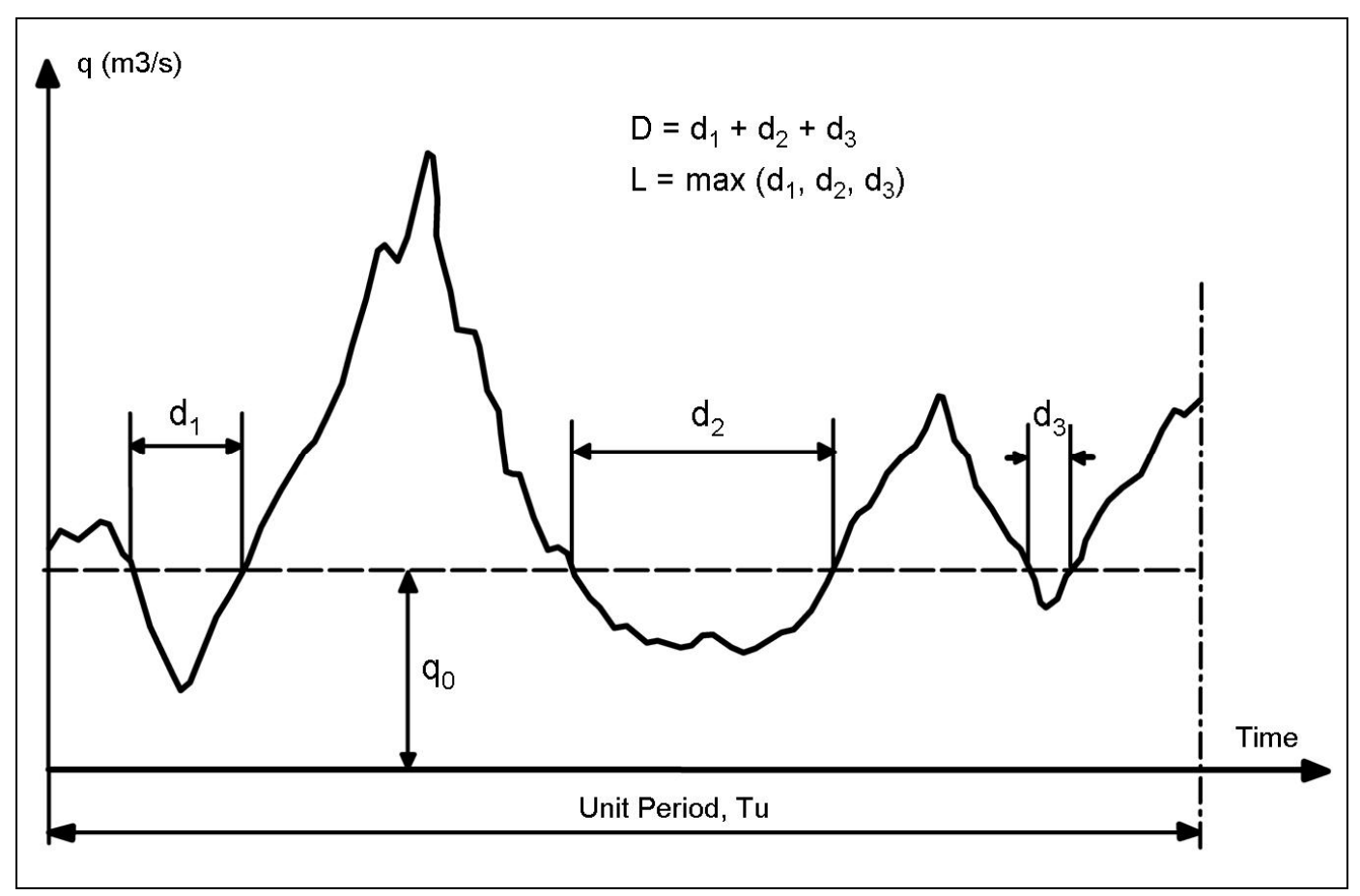

Figure 4.5: Graphical representation of the definitions of low flow duration D and longest low flow duration L (After Salas, 1980)

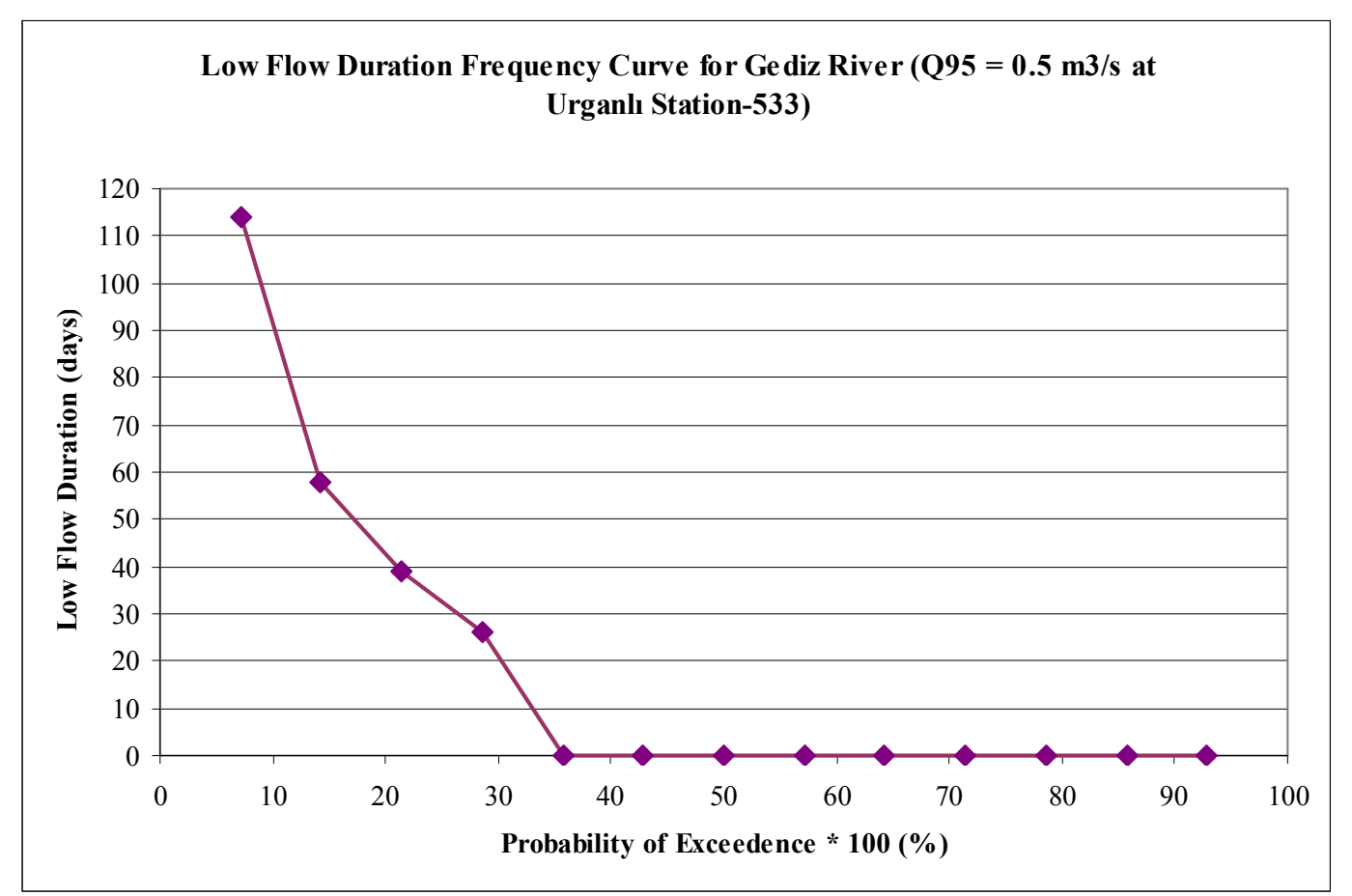

Figure 4.6: Low flow duration frequency curve for the Gediz River at Urganlı (No. 533) Station 


\subsubsection{Longest Low Flow Duration Frequency Curve}

Longest low flow duration (L) is defined as the largest of the low flow durations, i.e., $\mathrm{L}=\max \left(\mathrm{d}_{1}, \mathrm{~d}_{2}, \ldots . ., \mathrm{d}_{\mathrm{k}}\right)$ (Figure 4.5). Longest low flow durations corresponding to the specified discharge of $\mathrm{q}_{\mathrm{o}}=0.5 \mathrm{~m}^{3} / \mathrm{sec}$ was determined for each year and exceedence probabilities were calculated. The longest low flow duration frequency curve for the Gediz River is shown in Figure 4.7. Thus, the probability that the longest duration in which flows are lower than $0.5 \mathrm{~m}^{3} / \mathrm{sec}$ being greater than 15 days is about $30 \%$.

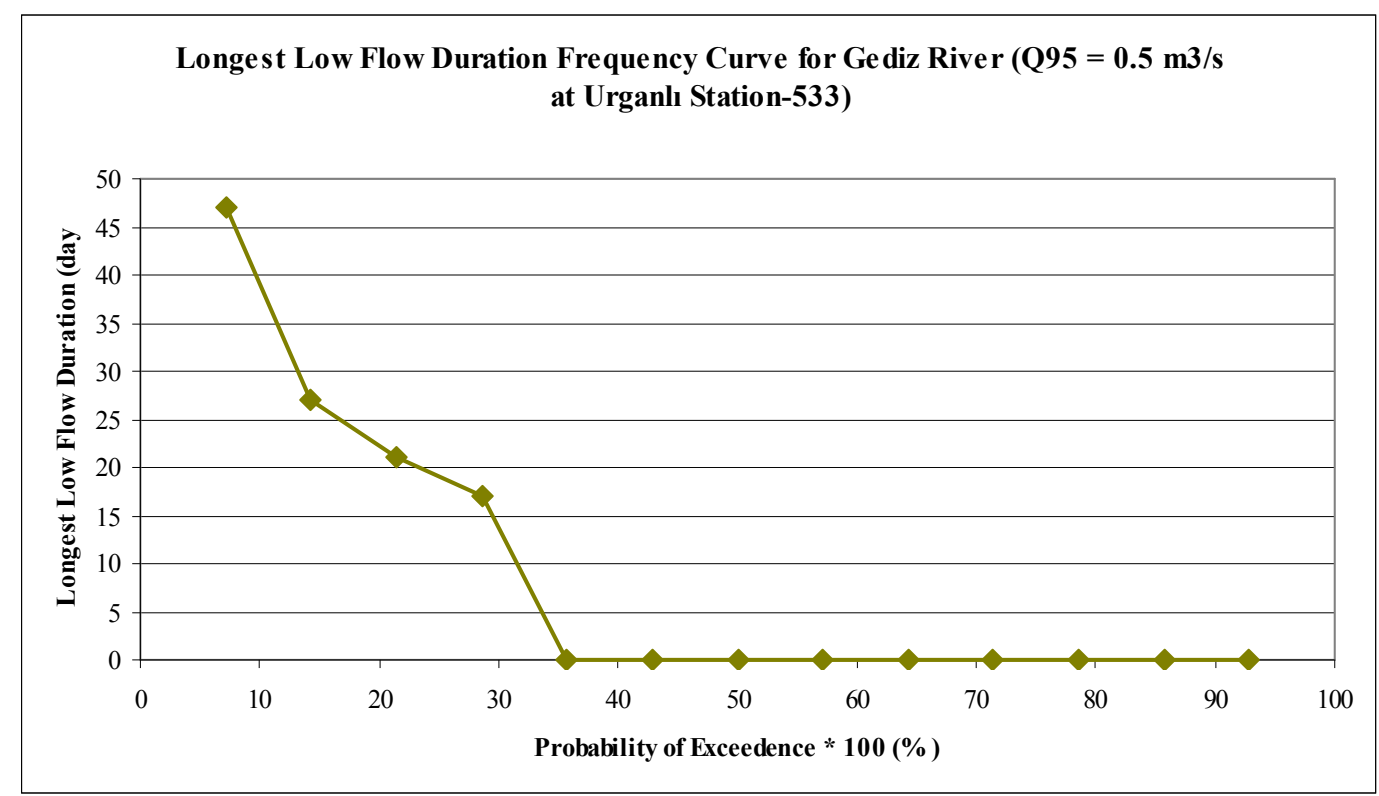

Figure 4.7: Longest low flow duration frequency curve for the Gediz River at Urganl1 (No. 533) Station 


\subsection{Alternative II: Groundwater}

Supplying water to the mine site from groundwater is the second alternative. In this alternative, it was assumed that all of the process water required for the mine was extracted from Turgutlu-Salihli aquifer. Turgutlu-Salihli aquifer is one of the three aquifers in the Gediz River Basin. Turgutlu-Salihli aquifer is the aquifer from which the process water is planned to be pumped because it is the closest aquifer to the Çaldağ Nickel Mine Site. To that end, a groundwater flow model for Turgutlu-Salihli aquifer was established to determine the location of the pumping wells for the mine and their potential effects on wells used for domestic, industrial and irrigation purposes.

\subsubsection{Groundwater Flow Model}

\subsubsection{Model Description}

The numerical groundwater flow model used for this study is the modular finitedifference groundwater flow model (MODFLOW-2000) developed by the U.S. Geological survey (USGS) (Harbaugh et al., 2000). The program was constructed in the early 1980's and has continually evolved since then with development of many new packages and related programs for groundwater studies. Currently, MODFLOW is the most widely used program in the world for simulating groundwater flow. MODFLOW was selected based on the following considerations:

- MODFLOW-2000 can simulate regional models, and visualize the results using $2 \mathrm{D}$ or $3 \mathrm{D}$ graphics

- MODFLOW-2000 is capable of simulating a wide variety of hydrogeologic processes in field conditions and various geological features.

- MODFLOW-2000 can simulate confined, unconfined and leaky aquifers under both steady state and transient conditions

Fully-integrated packages of MODFLOW-2000 enable one to simulate a variety of hydrogeological features, such as wells, reservoirs, streams, rivers, drains and springs, and hydrological processes like recharge and evapotranspiration. 
- Each simulation feature of the MODFLOW has been extensively tested.

\subsubsection{Conceptual Model of Aquifer System}

As discussed in depth in Chapter 3, Quaternary and Neogene units are the formations showing better aquifer properties than the other formations in the study area. Mesozoic limestone and Paleozoic marble also show good aquifer properties but because of their limited or disconnected outcrops, they were ignored while characterizing the Turgutlu-Salihli aquifer conceptually.

Conceptual model development is one of the most significant steps of numerical modeling. As a result of detailed examination of aquifer properties and evaluation of data, Quaternary and Neogene units were simulated as two separate layers in conceptual modeling. Because of similar hydraulic properties, alluvium, and old and young alluvial fans were considered as a single unit. Topographical map, and groundwater elevation and bottom elevation maps of Quaternary units were prepared as explained in Chapter 3. Neogene units consist of Pliocene and Miocene formations. Due to the similarity of hydraulic properties of these formations, they were modeled as a single unit. Bottom elevation map of Neogene was not prepared because of limited data about Neogene units. However, from the log of one of the wells drilled by DSI for the purpose of determination of basement of the aquifer, thickness of Neogene units was determined as $400 \mathrm{~m}$. Therefore, thickness of the Neogene units was assumed as constant throughout the whole model domain as 400 m.

As observed in geological map (Figure 2.11), although alluvium, alluvial fan and Neogene deposits spread over the southwestern part of the study area along the Nif valley, this part of the study area was simulated within Neogene aquifer because of lack of information about both groundwater elevations and bottom elevations for the alluvial units in that part. In the rest of the area, Quaternary and Neogene units were 
characterized separately in the numerical model, the upper layer representing the Quaternary aquifer and the lower representing the Neogene aquifer as seen in Figure 4.8 .

Both aquifers are subject to recharge from precipitation in the locations where they crop out. The upper aquifer is connected with the Gediz River as it can be depicted from the water table contour map given in Figure 3.17. Furthermore, it was assumed that the conditions observed in 1991 represented pseudo steady-state conditions before the development of extensive irrigation network as can be depicted from the rapid increase in number of wells drilled by DSI, Bank of Provinces and individuals (Figure 3.10).

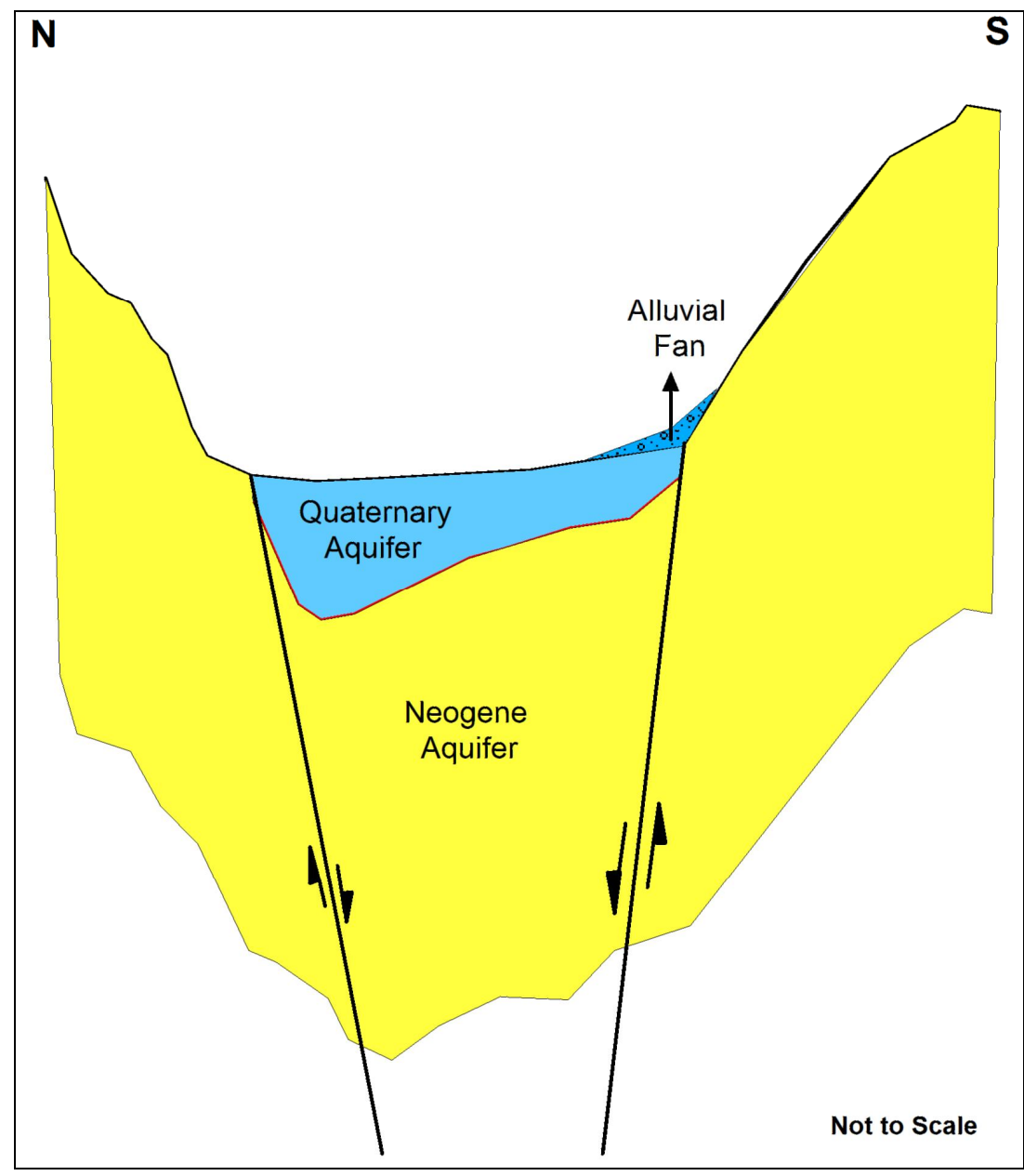

Figure 4.8: N-S oriented cross section showing modeled layers 


\subsubsection{Finite Difference Grid}

Minimum number of grids should be utilized to represent the heterogeneity of the aquifer, distribution of available data and aquifer boundaries. In the light of this information, grid size and its heterogeneity were determined.

The modeled domain and the finite difference grid are shown in Figure 4.9. The grid size of rows was minimized to $75 \mathrm{~m}$ along the Quaternary units because of the alignment of the Gediz River in the study area. To simulate the scenario wells better, grid size at the western part of the model domain was determined as $75 \mathrm{~m}$ by $75 \mathrm{~m}$. In eastern part, because of the areal changes Quaternary aquifer and density of wells grid size was refined up to $75 \mathrm{~m}$ by $75 \mathrm{~m}$. The coarser grids as $100 \mathrm{~m}$ by $200 \mathrm{~m}$ in the model domain represented the locations where there is lack of information especially in the vicinity of the boundaries between Neogene and impervious units (Figure 4.9).

\subsubsection{Boundary Conditions}

Boundaries of the model were determined according to geological and hydrogeological characteristics of the study area. Boundary conditions of the model were defined for both of the layers. Quaternary units forming the first layer spread in E-W direction. The underlying second layer including Neogene units spreads through the study area and also continues under the first layer as seen in Figure 4.10. For the first layer, the red hachured area seen in Figure 4.10 was simulated, and the area outside was defined as inactive. As can be seen from the groundwater elevation map (Figure 3.17) flow from northern and southern boundary to the alluvium was considered negligible except for the some portion of the southern boundary along the contact between Quaternary and Neogene units. That part of the boundary was simulated with general head boundary condition whereas the other parts were assigned as no-flow boundary. Eastern and northwestern boundaries were simulated by general head boundary condition because Gediz River Basin continues in east and west directions. Gölmarmara Lake forming the small portion of the northern 
boundary of the model was defined by constant head boundary condition with $70 \mathrm{~m}$ head elevation which is the average water level elevation at the lake.

The second layer was determined with green hachured area in Figure 4.10. Again, the boundary between Gölmarmara Lake and Neogene units were simulated by the constant head boundary condition with $70 \mathrm{~m}$ head elevation as the water level at the lake. Eastern, northwestern and southwestern boundaries were defined by the general head boundary conditions because there is recharge from southwestern and eastern boundaries and discharge from the northwestern boundary from the system. Boundary between Neogene and Paleozoic units, namely, southern and northern boundaries were assigned as no-flow boundary because of the hydraulic properties of the Paleozoic units.

Gediz River and its most important tributaries (Alaşehir Creek and Nif Creek) located in the study area were simulated with the River Package in the model (Figure 4.11 and Figure 4.12). Urganl1 spring is the most important spring in the study area. Because of its ignorable discharge rate, it was not simulated in the model.

In the model, upper hydrogeological boundary is the groundwater table except in the vicinity of Gediz River, and Alaşehir and Nif Creek. Lower boundary is the impervious Paleozoic rocks forming the basement rocks in the study area.

Boundary conditions of both of the layers are given in Figure 4.11 for upper layer and Figure 4.12 for lower layer. Well Package was used to simulate groundwater extraction. Wells located in upper and lower layers are also shown in Figure 4.11 and Figure 4.12, respectively. 


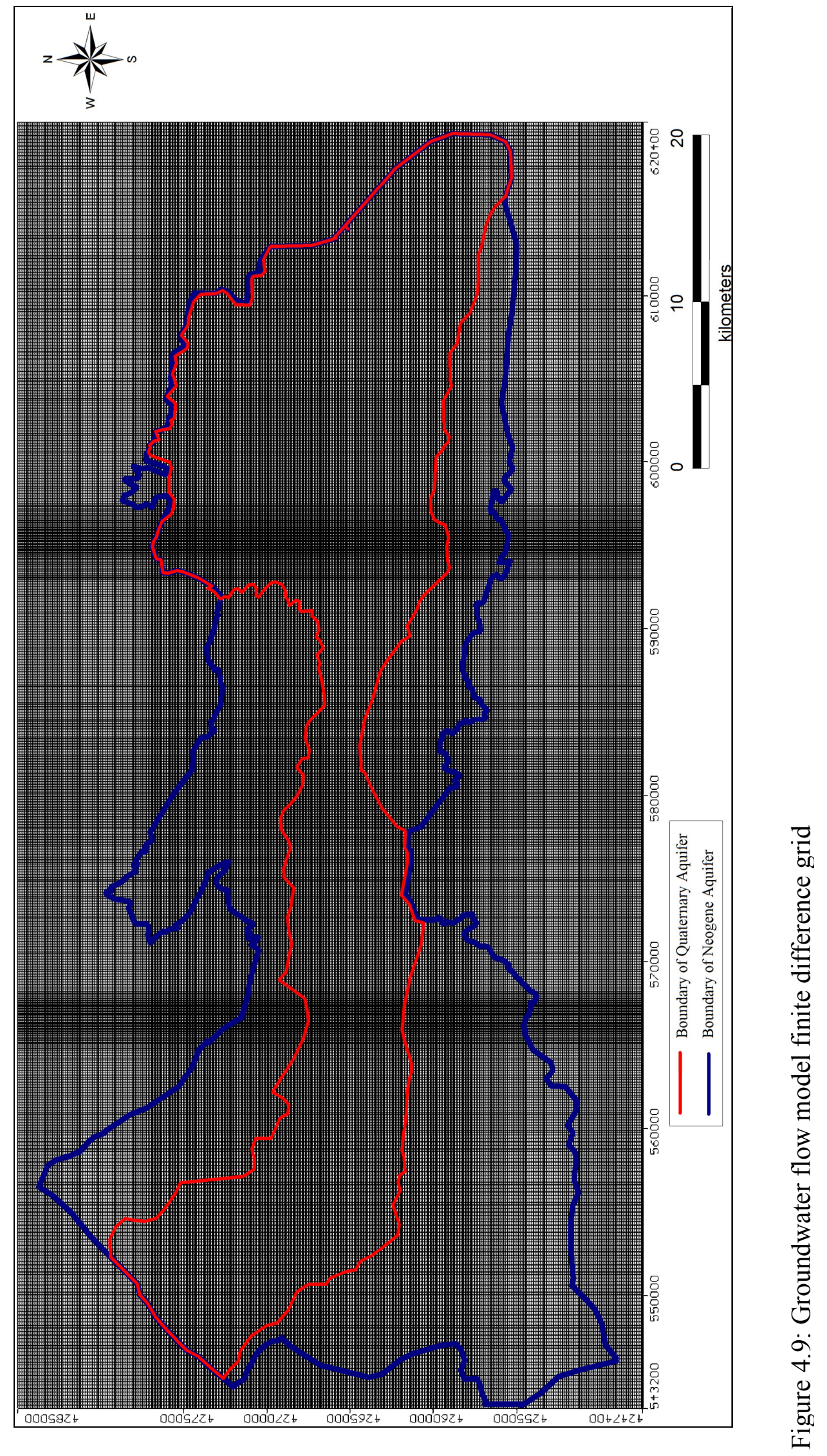




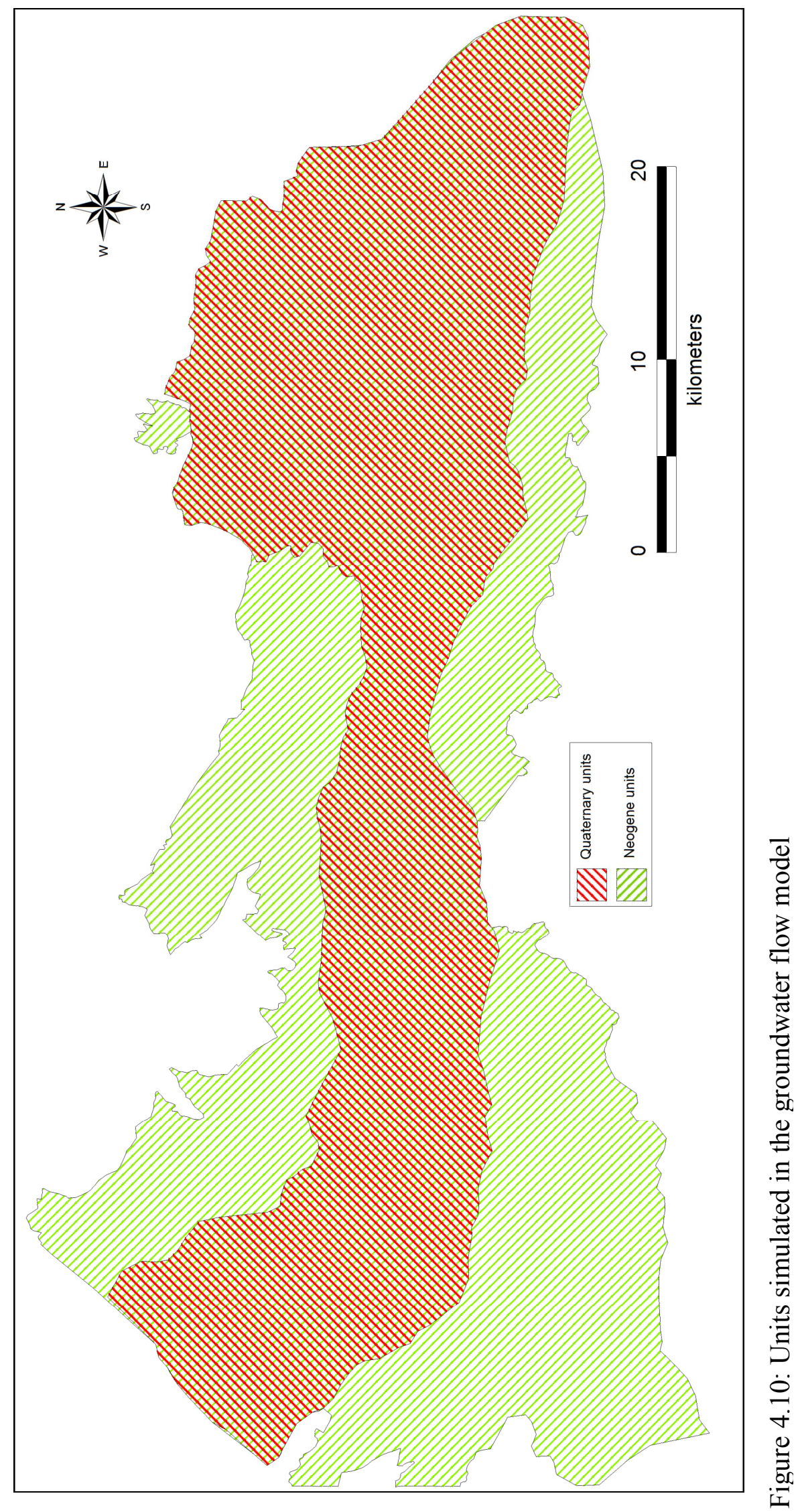




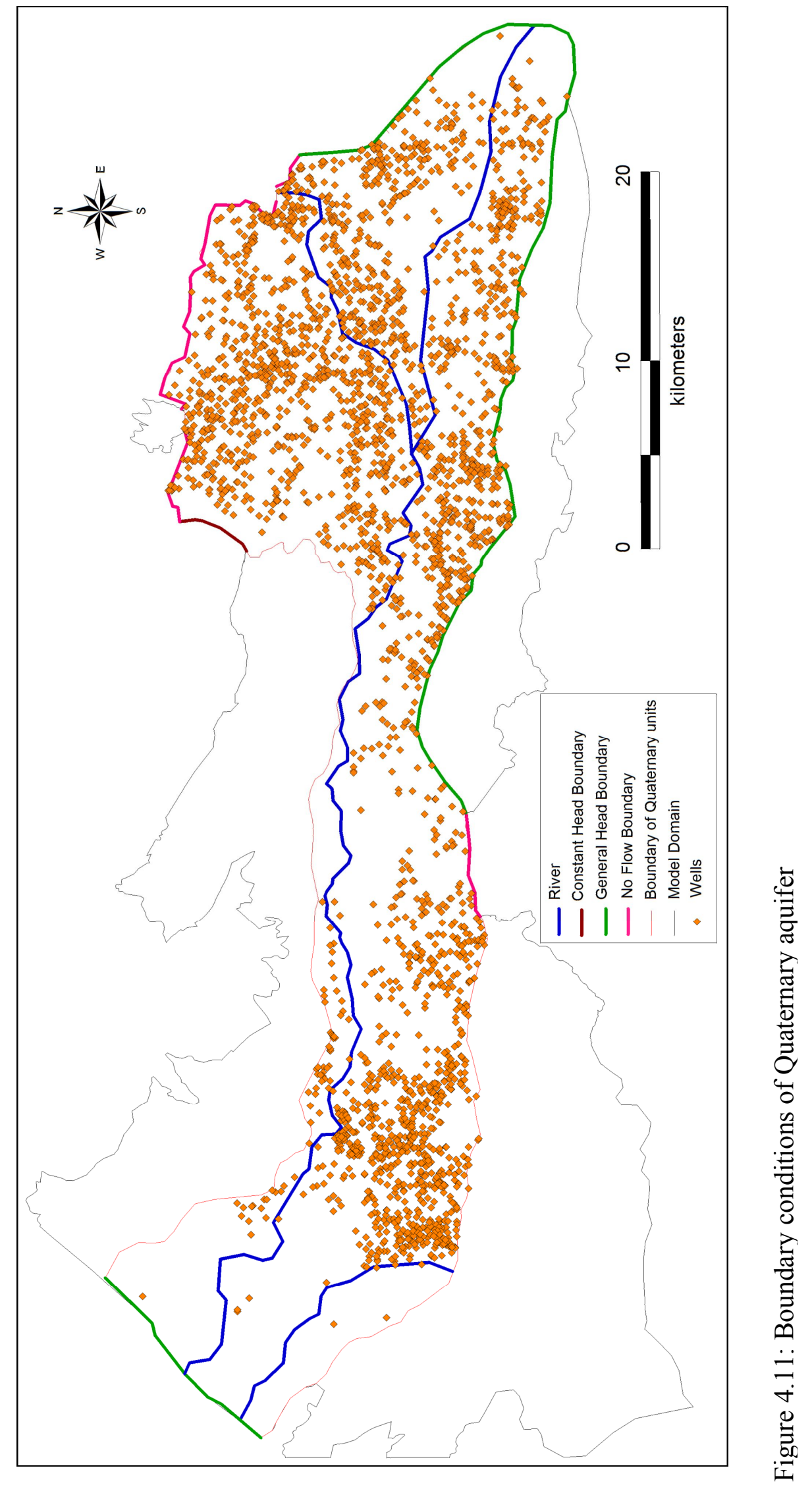




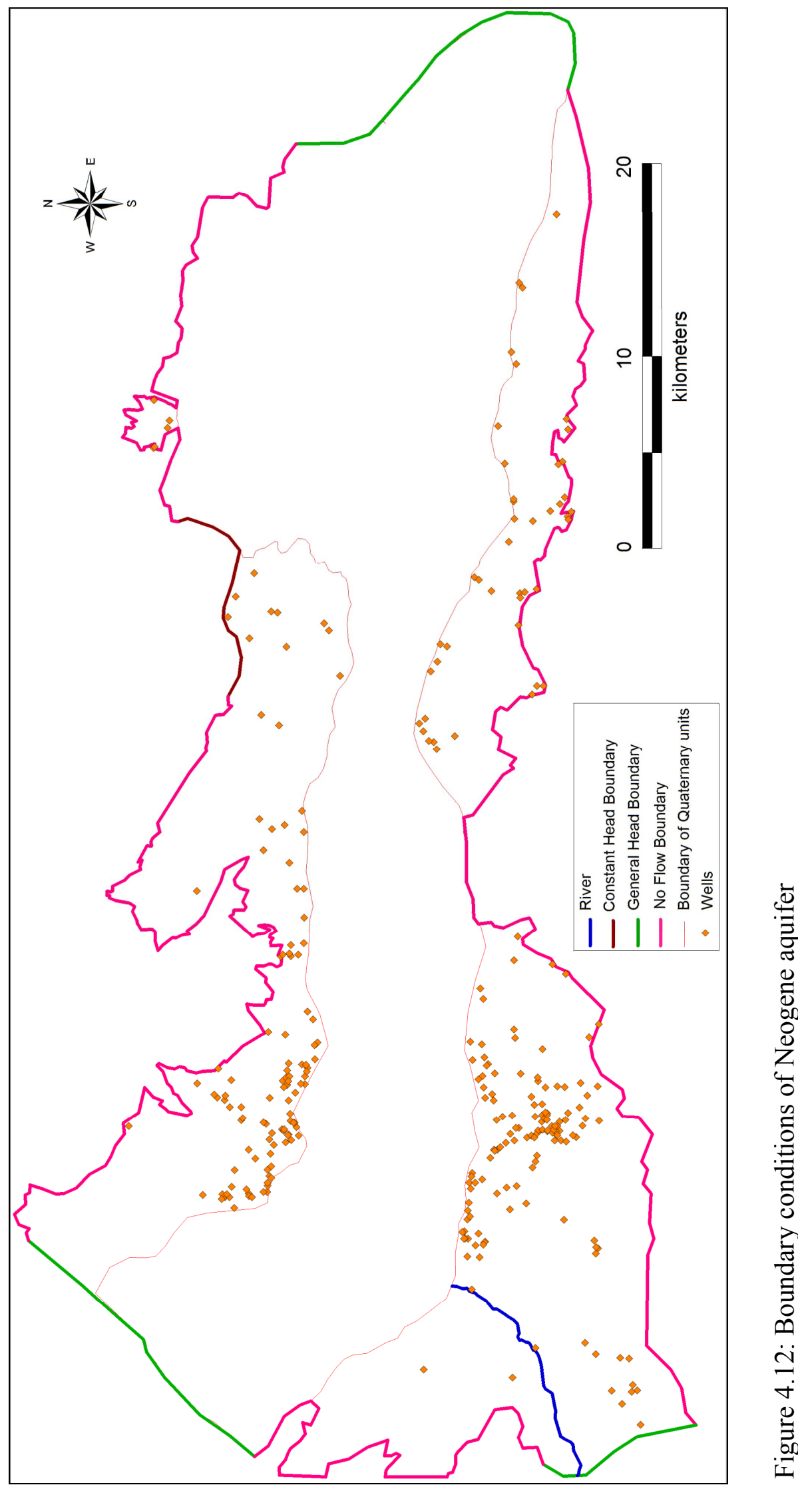




\subsubsection{Hydraulic Parameters}

Some pumping test results for the Quaternary units were available to obtain hydraulic conductivity value for that unit as explained in Chapter 3. Considering the regional nature of the model and the lack of spatially covered data distribution, a uniform value of $4 \mathrm{~m} / \mathrm{d}$ was assigned to the alluvium part of the Quaternary aquifer. This value is equal to the geometric mean of the hydraulic conductivity values calculated from pumping tests. A hydraulic conductivity of $8 \mathrm{~m} / \mathrm{d}$ was assigned for alluvial fan deposits as they are more permeable than the alluvium (Figure 4.13). Although some DSİ wells penetrate into Neogene formations, pumping test results were not available. However, it is known from well yields, specific capacities and geophysics analysis that the hydraulic conductivity of Neogene aquifer must be smaller than that of the Quaternary aquifer and hence a value of $2 \mathrm{~m} / \mathrm{d}$ was assigned. The vertical hydraulic conductivities for both layers were assumed to be equal to $1 / 10^{\text {th }}$ of the horizontal hydraulic conductivity in that layer.

As explained in Conceptual model part, the alluvial system in the southwestern part of the study area drained by the Nif stream was included in the Neogene aquifer. To take into account this condition, different hydraulic conductivity value was assigned to that part of the Neogene aquifer (Figure 4.14). The hydraulic conductivity value assigned to that part was calculated as $2.26 \mathrm{~m} / \mathrm{d}$ using the Equation 4.1.

$$
\left(K_{x}\right)_{i, j}=\sum_{k=1}^{m} \frac{K_{i, j, k} b_{i, j, k}}{B_{i, j}}
$$

where,

$\mathrm{K}_{\mathrm{x}} \quad$ : horizontal hydraulic conductivity through layered aquifer,

$\mathrm{K}$ : hydraulic conductivity of each layer $\left(\mathrm{K}_{1}=4 \mathrm{~m} / \mathrm{d}\right.$ and $\left.\mathrm{K}_{2}=2 \mathrm{~m} / \mathrm{d}\right)$,

b : thickness of each layer $\left(b_{1}=\sim 60 \mathrm{~m}\right.$ and $\left.b_{2}=400 \mathrm{~m}\right)$,

B : total thickness $(B=460 \mathrm{~m})$. 


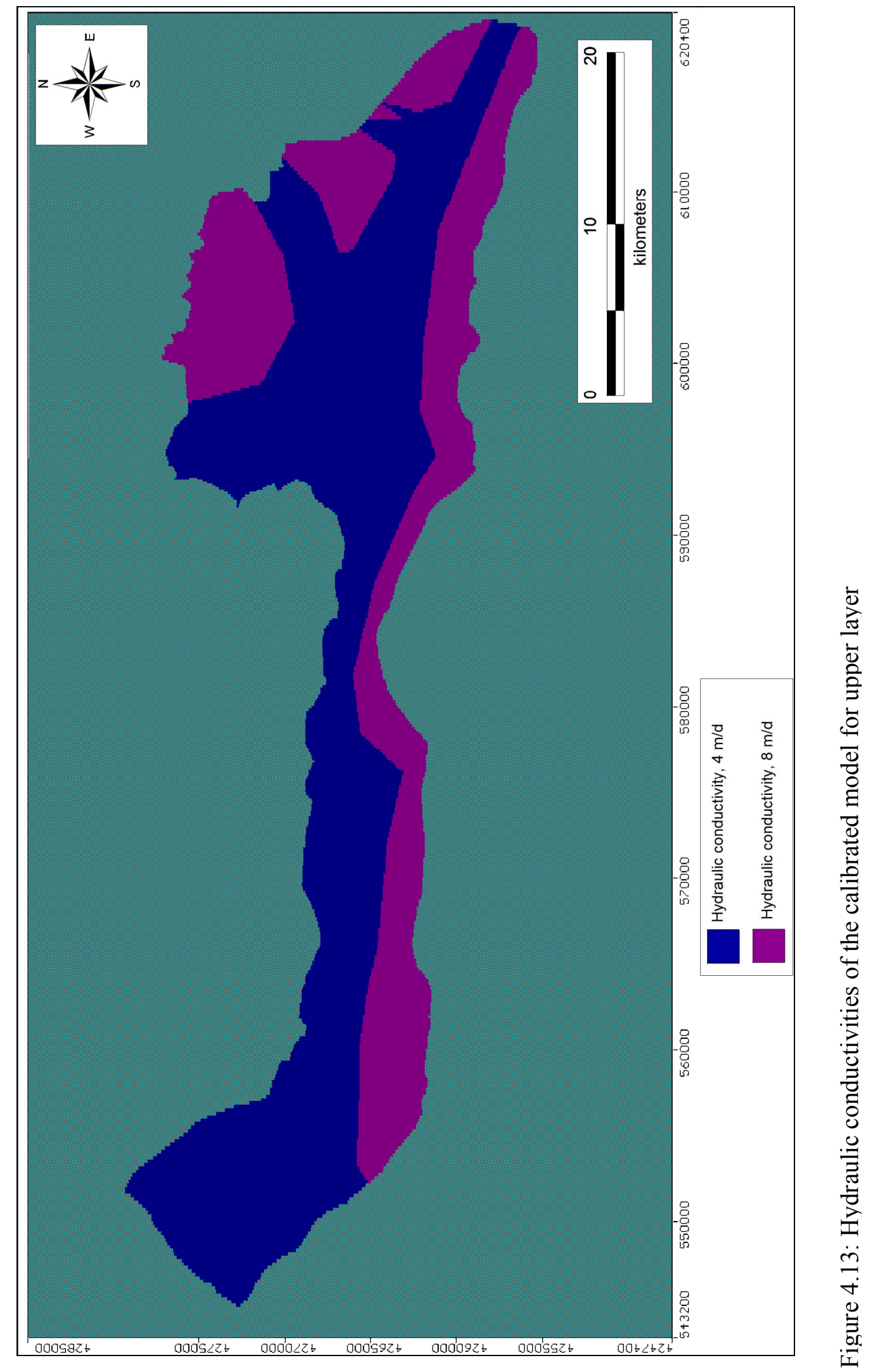




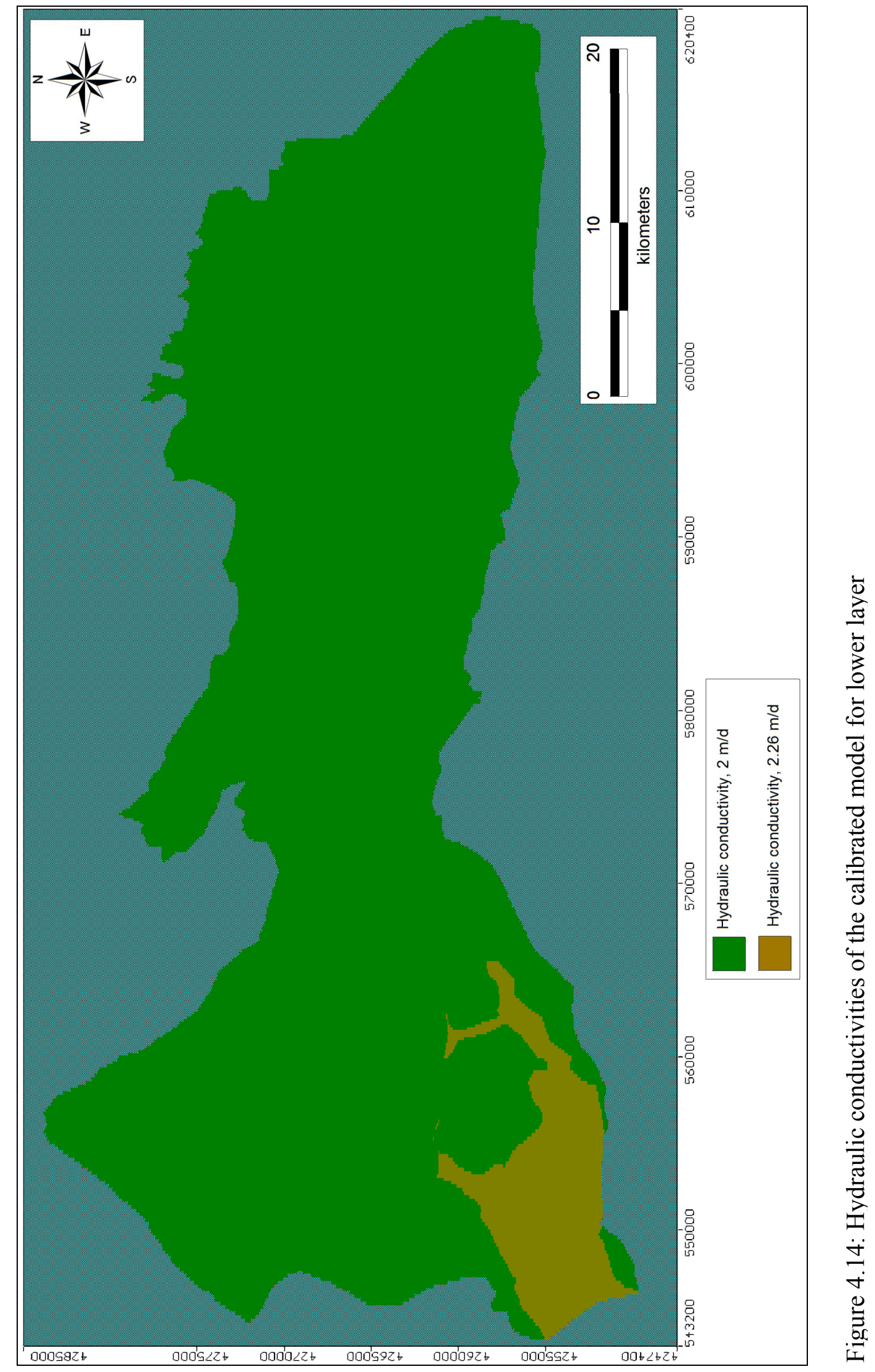




\subsubsection{Areal Recharge}

Recharge from precipitation is the most important source for groundwater recharge. Precipitation data measured from Turgutlu and Salihli stations were considered because of long-term data availability and their representative location. Precipitation data collected from these two stations were analyzed to determine the recharge from them using the Thornthwaite method (Thornthwaite, 1948). The analyses were performed for the year 1991 using monthly precipitation, temperature and runoff coefficient to calculate a percolation rate to groundwater system by assuming an initial soil moisture content of $100 \mathrm{~mm}$. The results of the Thornthwaite method show that recharge from both of the stations are approximately equal to $89 \mathrm{~mm} /$ year. This value was assigned as the areal recharge rate from precipitation to the modal domain.

In addition to recharge from precipitation, there is an extra recharge that results from the surface flow percolating into groundwater through old alluvial fan in the northeast part of the study area from the upstream mountainous region. The amount of this extra recharge from the surface flow was calculated by determining amount of surface flow to percolate through old alluvial fan, area of mountainous region and area of old alluvial fan. Annual precipitation value $(493 \mathrm{~mm})$ of Salihli station was used because Salihli station is the closest station to the mountainous region as seen in Figure 4.15. As it is stated by DSİ (1983) $20 \%$ of the annual precipitation flows, and for the alluvial fans $90 \%$ of the surface flows percolates into groundwater in the Gediz river Basin. Therefore, using annual precipitation of Salihli meteorological station it was calculated that $89 \mathrm{~mm} /$ year percolates into the groundwater annually through old alluvial fan. When annually $89 \mathrm{~mm}$ recharge from $34.85 \mathrm{~km}^{2}$ of mountainous region was distributed over the $60.95 \mathrm{~km}^{2}$ of old alluvial fan area, the extra recharge from surface flow was calculated as $51 \mathrm{~mm} /$ year as given in Figure 4.15 . 


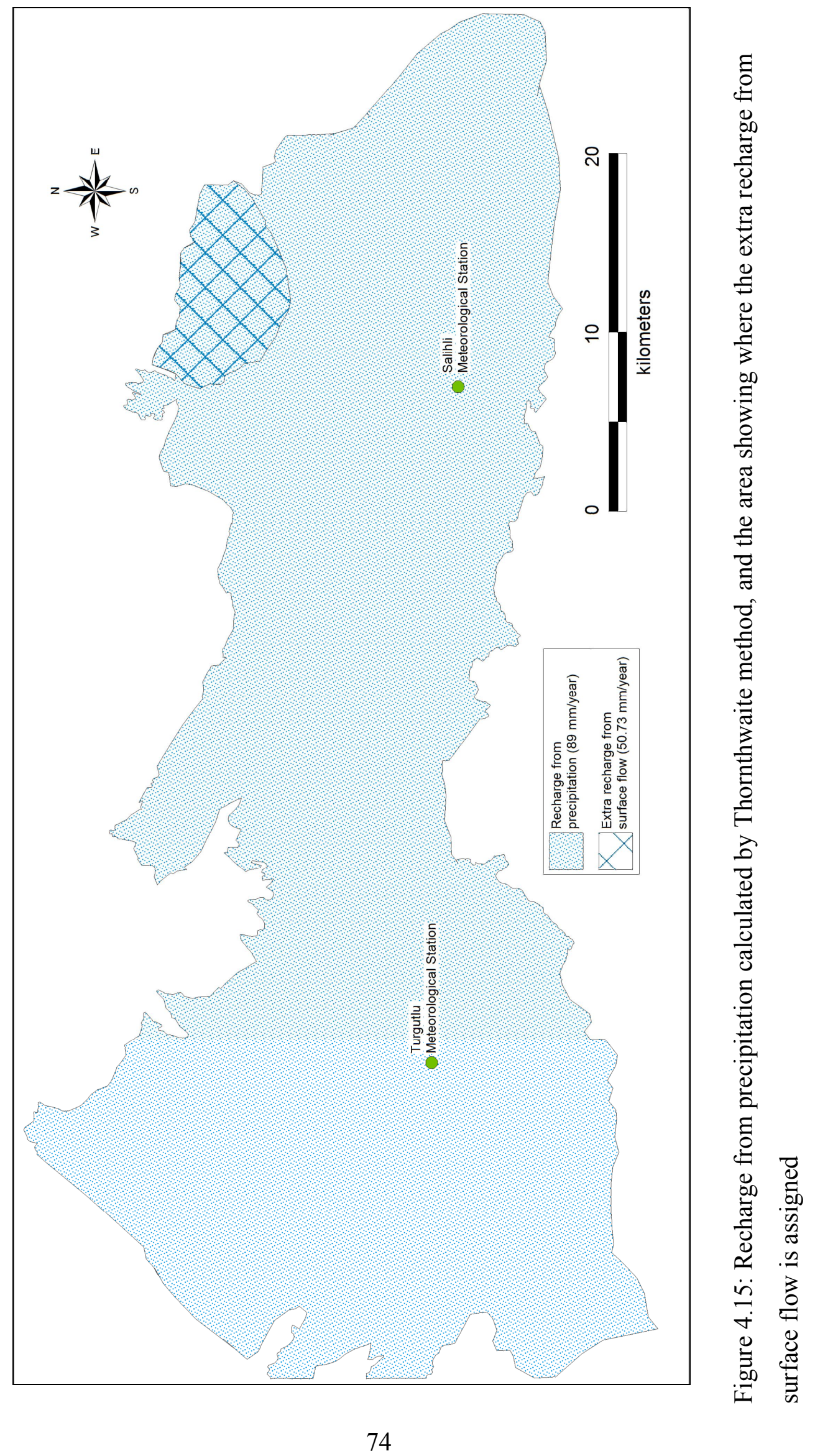




\subsubsection{Pumpage from Wells}

Quaternary and Neogene aged units bearing groundwater were assumed to represent two separate aquifers in the numerical flow model. Amount of water extracted from these units were calculated to determine the total groundwater consumption. Groundwater in the basin is extracted for two purposes; namely, drinking, domestic and industrial uses, and irrigational uses.

Groundwater to be used for drinking, domestic and industrial purposes is extracted from wells drilled by DSİ, Bank of Provinces and individuals, whereas wells pumped for irrigational purposes are the individuals' and DSİ wells. The locations of these wells are shown in Figure 4.16. Wells drilled for irrigational purposes by DSİ are used to supply irrigation water to Adala Irrigation Cooperative. Although most of the individuals' wells were drilled for irrigational purposes, there is small number of wells drilled for drinking water purposes.

To calculate the amount of water extracted from these wells, information about the water supply wells were collected from DSI $-2^{\text {nd }}$ District Office and Bank of Provinces. The results of census of year 2000 were obtained from DİE. For irrigation wells, data were gathered from DSİ- $2^{\text {nd }}$ District Office. Data collected from DİE and DSİ- ${ }^{\text {nd }}$ District Office were utilized to relate amount of groundwater consumed and population. Groundwater consumption for municipalities and villages were assumed to be $250 \mathrm{~L} /$ day/capita and $200 \mathrm{~L} /$ day/capita, respectively. These values were determined by Yazicigil et al. (2000) as a result of detailed study carried out for the Küçük Menderes River Basin. Gediz and Küçük Menderes River Basins are adjacent basins, so groundwater consumptions are similar to each other. Under the light of this information groundwater consumption was calculated as $21.2 \mathrm{hm}^{3} /$ year from water supply wells, and as $112.3 \mathrm{hm}^{3} / \mathrm{yr}$ from irrigation wells as seen in Table 4.1. Thus, total groundwater pumped from both aquifers is equal to $133.5 \mathrm{hm}^{3} / \mathrm{yr}$, of which approximately three-fourths are pumped from the Quaternary aquifer. 


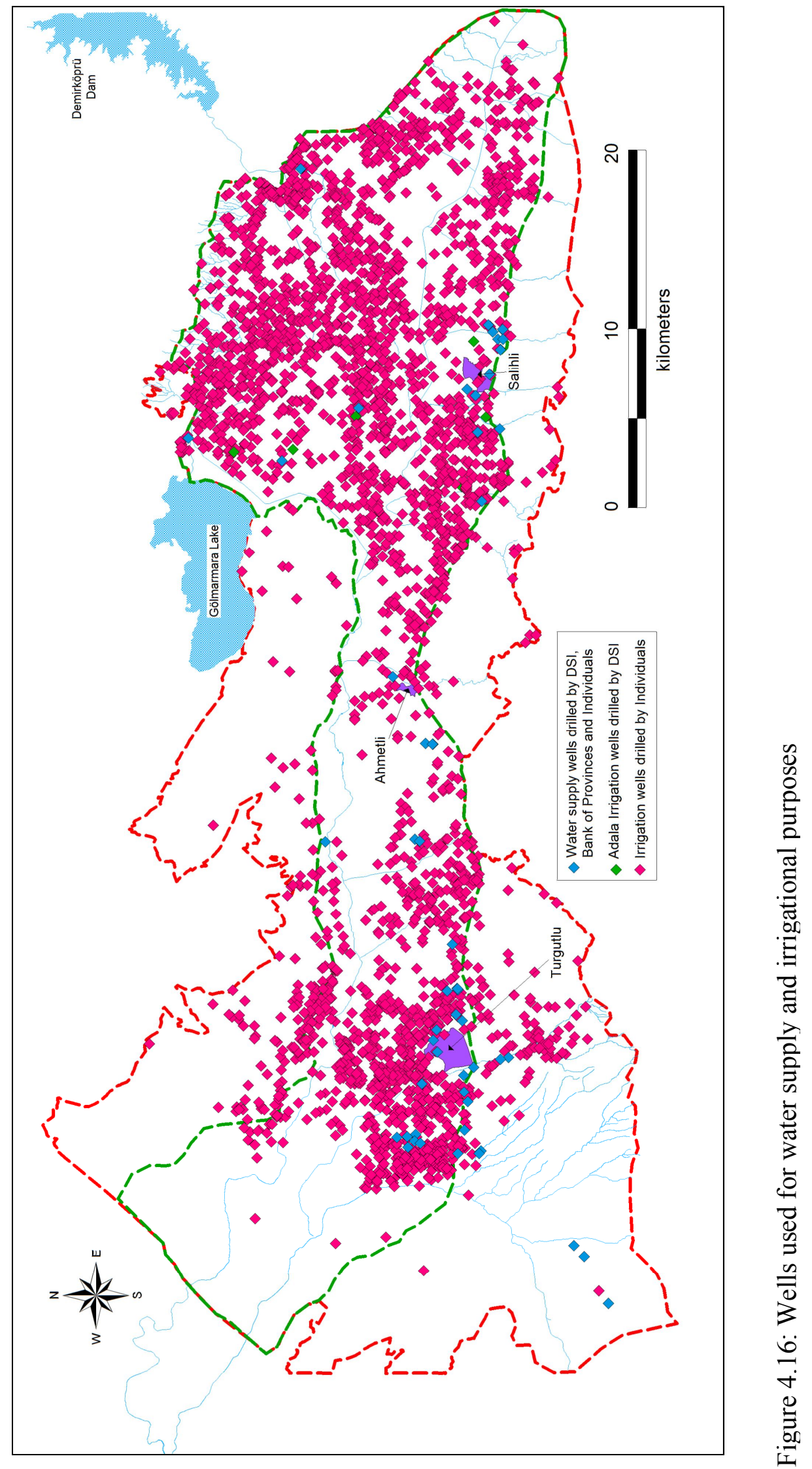


Table 4.1: Groundwater consumption

\begin{tabular}{|c|c|c|c|c|c|c|}
\hline \multirow{2}{*}{} & \multicolumn{2}{|c|}{$\begin{array}{c}\text { Drinking, domestic and } \\
\text { industrial purposes }\end{array}$} & \multicolumn{2}{|c|}{ Irrigational purposes } & \multicolumn{2}{|c|}{ Total } \\
\cline { 2 - 7 } & $\mathrm{m}^{3} / \mathrm{d}$ & $\mathrm{hm}^{3} / \mathrm{y}$ & $\mathrm{m}^{3} / \mathrm{d}$ & $\mathrm{hm}^{3} / \mathrm{y}$ & $\mathrm{m}^{3} / \mathrm{d}$ & $\mathrm{hm}^{3} / \mathrm{y}$ \\
\hline $\begin{array}{c}\text { Quaternary units } \\
\text { (Alluvium) }\end{array}$ & $30,761.0$ & 11.2 & $264,916.0$ & 96.7 & $295,677.0$ & 107.9 \\
\hline Neogene units & $27,397.3$ & 10.0 & $42,767.1$ & 15.6 & $70,137.0$ & 25.6 \\
\hline Total & $58,158.3$ & 21.2 & $307,683.1$ & 112.3 & $365,841.4$ & 133.5 \\
\hline
\end{tabular}

\subsubsection{Calibration of the Groundwater Flow Model}

After all of the inputs (top and bottom elevation maps of the layers, model grid, boundary conditions, recharge and discharge parameters, and hydraulic parameters of units) were entered into the model, calibration of the groundwater flow model was carried out. The model was calibrated under steady state conditions assuming that the conditions in 1991 prior to the significant development represented a pseudo-steady state in the aquifer system. Because of lack of significant water level data for the secondary aquifer, calibration was mainly carried out for the upper layer.

During the calibration step, the match of observed and calculated groundwater levels and consistency of the conceptual and calculated budget of the system were the primary criteria. Consequently, to obtain a good match some of the input parameters like hydraulic conductivity, recharge and boundary conditions were modified as mentioned in previous sections. These modifications were carried out by trial and error without going beyond the hydrogeological and geological limits of the parameters. 


\subsubsection{Root Mean Square Error (RMS) and RMS Percentage}

The goodness of the match between observed and calculated water levels was obtained by the Root Mean Square Error (RMS) which was minimized. RMS is defined by the Equation 4.2. Root Mean Square Error Percentage (RMS (\%)) is the RMS divided by the maximum difference in the observed head values. It is expressed by the Equation 4.3. The RMS percentage is a more representative measure of the fit than the standard RMS, as it accounts for the scale of the potential range of data values.

$$
\begin{aligned}
& R M S=\sqrt{\frac{1}{n} \sum_{i=1}^{n}\left(h_{o b s}-h_{c a l}\right)_{i}^{2}} \\
& R M S(\%)=\frac{R M S}{\left(h_{o b s}\right)_{\max }-\left(h_{o b s}\right)_{\min }}
\end{aligned}
$$

where,

$$
\begin{aligned}
& \mathrm{n} \quad \text { : total number of observation points, } \\
& \mathrm{h}_{\mathrm{obs}} \quad \text { : observed groundwater level, } \\
& \mathrm{h}_{\mathrm{cal}} \quad \text { : calculated groundwater level. }
\end{aligned}
$$

The RMS was calculated by comparing the calculated and observed water levels at the locations of the observation wells shown in Figure 4.17. The calibration error statistics for the final model run are presented in Figure 4.18. The model was calibrated with an RMS value of $8.44 \mathrm{~m}$ and RMS percentage of $9.87 \%$. These error statistics are acceptable considering the regional nature of the model and the homogeneity of the input parameters used. Hence, it can be concluded that there is a good match between observed and calculated groundwater levels. Figure 4.18 shows the areal distribution of the calculated water levels in the Quaternary aquifer. The good match noted between the areal distribution of observed (Figure 3.17) and calculated water levels (Figure 4.19) also confirm that the model is capable of simulating the regional flow patterns in the study area. 


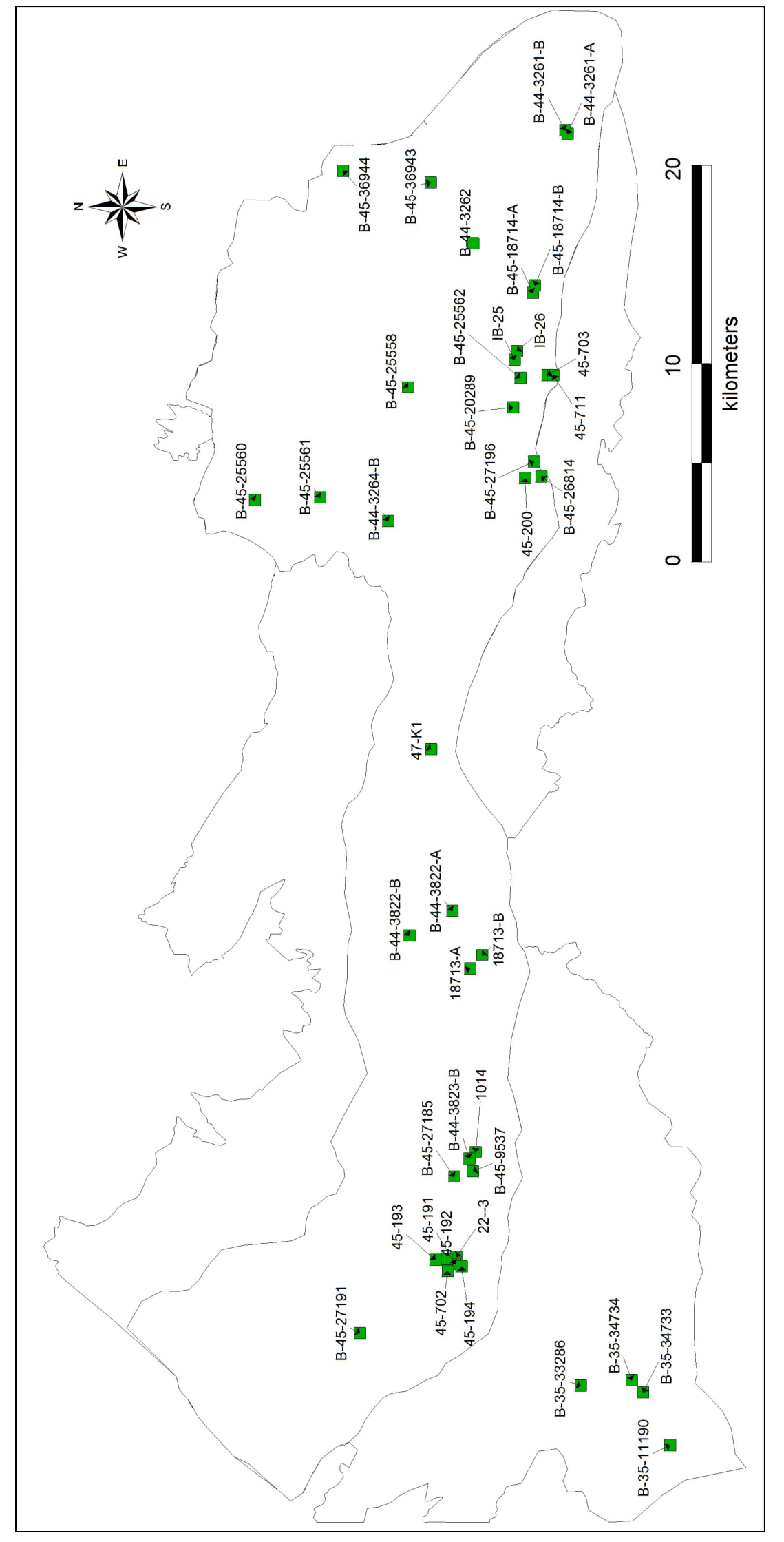

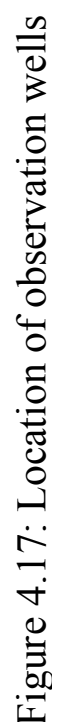




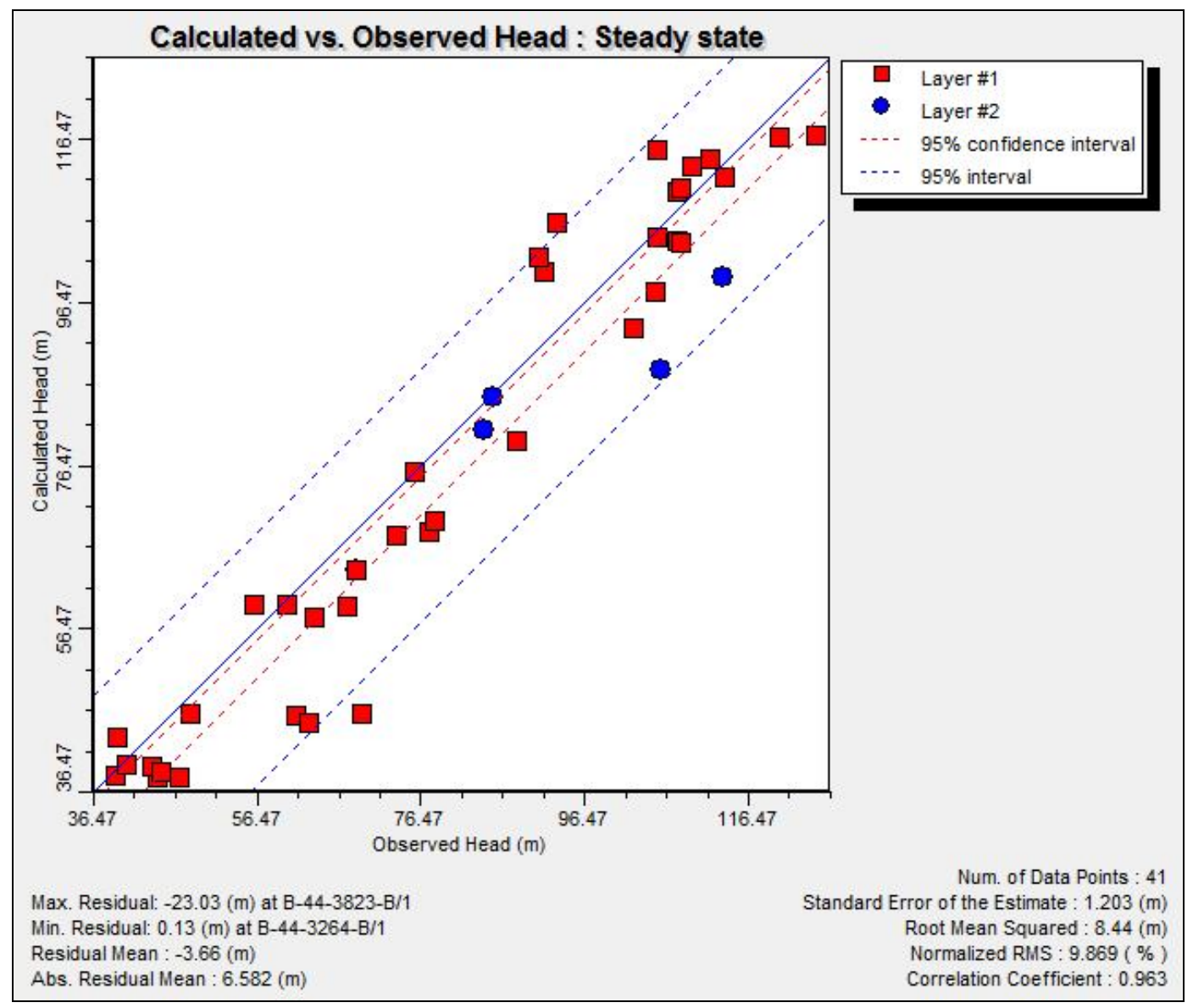

Figure 4.18: The graphical relation between calculated and observed groundwater levels for both aquifers 


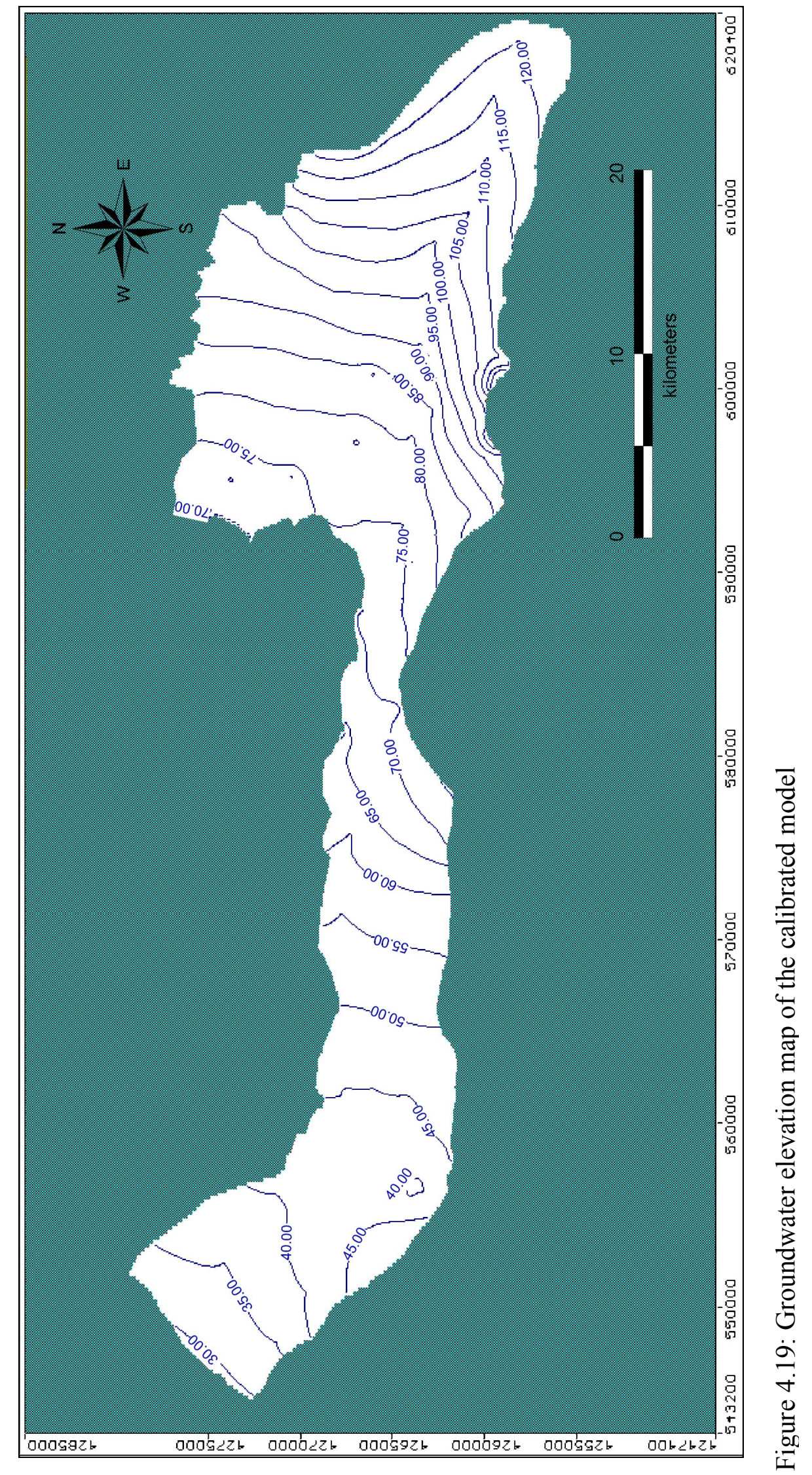




\subsubsection{Calculated Groundwater Budget}

During the calibration step, the budget of the model was also compared with the budget prepared by DSİ for Turgutlu-Salihli aquifer system in 1983. The calculated water budget for the Quaternary aquifer system is comparable with the budget calculated by DSİ considering the areal and the timing differences between the two. Groundwater budgets of both Quaternary and Neogene aquifers calculated at the end of the calibration are given in Table 4.2 and Table 4.3 , respectively.

Recharge components of the Quaternary units of the model are under flow from Salihli (26.13 $\mathrm{hm}^{3} /$ year), recharge from rainfall $\left(65.39 \mathrm{hm}^{3} /\right.$ year), recharge from Gediz River (6.81 $\mathrm{hm}^{3} /$ year), recharge from Neogene aquifer to Quaternary aquifer from southern boundary $\left(75.63 \mathrm{hm}^{3} /\right.$ year $)$ and flow from Neogene aquifer to Quaternary aquifer $\left(74.70 \mathrm{hm}^{3} /\right.$ year). Total recharge through Quaternary aquifer is $248.66 \mathrm{hm}^{3} /$ year. As can be seen in Table 4.2, $1.38 \%\left(3.43 \mathrm{hm}^{3} /\right.$ year $)$ of the total recharge is discharged from northwestern boundary, $42.65 \%\left(106.05 \mathrm{hm}^{3} /\right.$ year $)$ is pumped from wells, $39.32 \%$ (97.77 $\mathrm{hm}^{3} /$ year) is discharged into Gediz River, 0.23 $\%\left(0.59 \mathrm{hm}^{3} /\right.$ year $)$ is discharged into Gölmarmara Lake and $16.42 \%$ (40.82 $\mathrm{hm}^{3} /$ year) is discharged into Neogene units.

Neogene aquifer as a bottom layer of the model is recharged through under flow from Salihli (6.71 $\mathrm{hm}^{3} /$ year), from rainfall $\left(59.93 \mathrm{hm}^{3} /\right.$ year), from Gediz River $(0.41$ $\mathrm{hm}^{3} /$ year), flow from Kemalpaşa $\left(10.57 \mathrm{hm}^{3} /\right.$ year) and from flow from Quaternary aquifer to Neogene aquifer $\left(40.82 \mathrm{hm}^{3} /\right.$ year). Total recharge of the Neogene aquifer is calculated as $118.44 \mathrm{hm}^{3} /$ year. As can be seen from Table 4.3, $7.37 \%(8.73$ $\mathrm{hm}^{3} /$ year) of the total recharge is discharged from northwestern boundary, $21.81 \%$ $\left(25.83 \mathrm{hm}^{3} /\right.$ year $)$ is pumped from wells, $2.99 \%\left(3.54 \mathrm{hm}^{3} /\right.$ year) is discharged into Gediz River in the southwestern part, $4.54 \%\left(5.38 \mathrm{hm}^{3} /\right.$ year $)$ is discharged into Gölmarmara Lake and $63.07 \%\left(74.70 \mathrm{hm}^{3} /\right.$ year $)$ is discharged into Quaternary units. 
Table 4.2: Groundwater budget of calibrated model for Quaternary aquifer

\begin{tabular}{|c|c|c|c|}
\hline \multicolumn{2}{|c|}{ Recharge $\left(\mathrm{hm}^{3} /\right.$ year $)$} & \multicolumn{2}{c|}{ Discharge $\left(\mathrm{hm}^{3} /\right.$ year $)$} \\
\hline Under flow from Salihli & 26.13 & $\begin{array}{c}\text { Outflow from northwestern } \\
\text { boundary }\end{array}$ & 3.43 \\
\hline Recharge from Rainfall & 65.39 & Wells & 106.05 \\
\hline Recharge from Gediz River & 6.81 & Discharge to Gediz River & 97.77 \\
\hline $\begin{array}{c}\text { Recharge from Neogene to } \\
\text { Quaternary in Southern } \\
\text { Boundary }\end{array}$ & 75.63 & Discharge to Gölmarmara & 0.59 \\
\hline $\begin{array}{c}\text { Flow from Neogene aquifer } \\
\text { to Quaternary aquifer }\end{array}$ & 74.70 & $\begin{array}{c}\text { Flow from Quaternary aquifer to } \\
\text { Neogene aquifer }\end{array}$ & 40.82 \\
\hline Total Recharge & 248.66 & Total Discharge & 248.66 \\
\hline
\end{tabular}

Table 4.3: Groundwater budget of calibrated model for Neogene aquifer

\begin{tabular}{|c|c|c|c|}
\hline \multicolumn{2}{|c|}{ Recharge $\left(\mathrm{hm}^{3} /\right.$ year $)$} & \multicolumn{2}{c|}{ Discharge $\left(\mathrm{hm}^{3} /\right.$ year $)$} \\
\hline Under flow from Salihli & 6.71 & $\begin{array}{c}\text { Outflow from northwestern } \\
\text { boundary }\end{array}$ & 8.73 \\
\hline Recharge from Rainfall & 59.93 & Wells & 25.83 \\
\hline Recharge from Gediz River & 0.41 & Discharge to Gediz River & 3.54 \\
\hline Under Flow from Kemalpaşa & 10.57 & Discharge to Gölmarmara & 5.38 \\
\hline $\begin{array}{c}\text { Flow from Quaternary } \\
\text { aquifer to Neogene aquifer }\end{array}$ & 40.82 & $\begin{array}{c}\text { Flow from Neogene aquifer to } \\
\text { Quaternary aquifer }\end{array}$ & 74.70 \\
\hline Total Recharge & 118.44 & Total Discharge & 118.18 \\
\hline
\end{tabular}

\subsubsection{Sensitivity Analysis}

Sensitivity analysis was carried out to identify the effect of parameters on the model results. The sensitivity simulations were done by changing one input parameter at a time, while keeping the other parameters constant. For the calibrated model of the study area, sensitivity analyses were performed for hydraulic conductivity and recharge parameters.

First of all, the hydraulic conductivities assigned to the upper layer were modified. The hydraulic conductivities of the lower layer were changed, and then to observe the overall effect the ones in both of the layers were modified at the same time. Results are given in Figure 4.20, Figure 4.21 and Figure 4.22. These results indicate that the model is very sensitive to lowering of the calibrated hydraulic conductivities 
in both layers as well as in individual layers. Moreover, increase in hydraulic conductivities produced a slight decrease in RMS values. Model responded to the change in recharge in nearly the same way as the change in hydraulic conductivities. However, when recharge was increased more than 2 times of the recharge value used in the calibrated model, decreasing RMS was started to increase as seen in Figure 4.23. Results show that the increase in coefficients of hydraulic conductivity and recharge is better than the calibrated values; however, it is physically impossible.

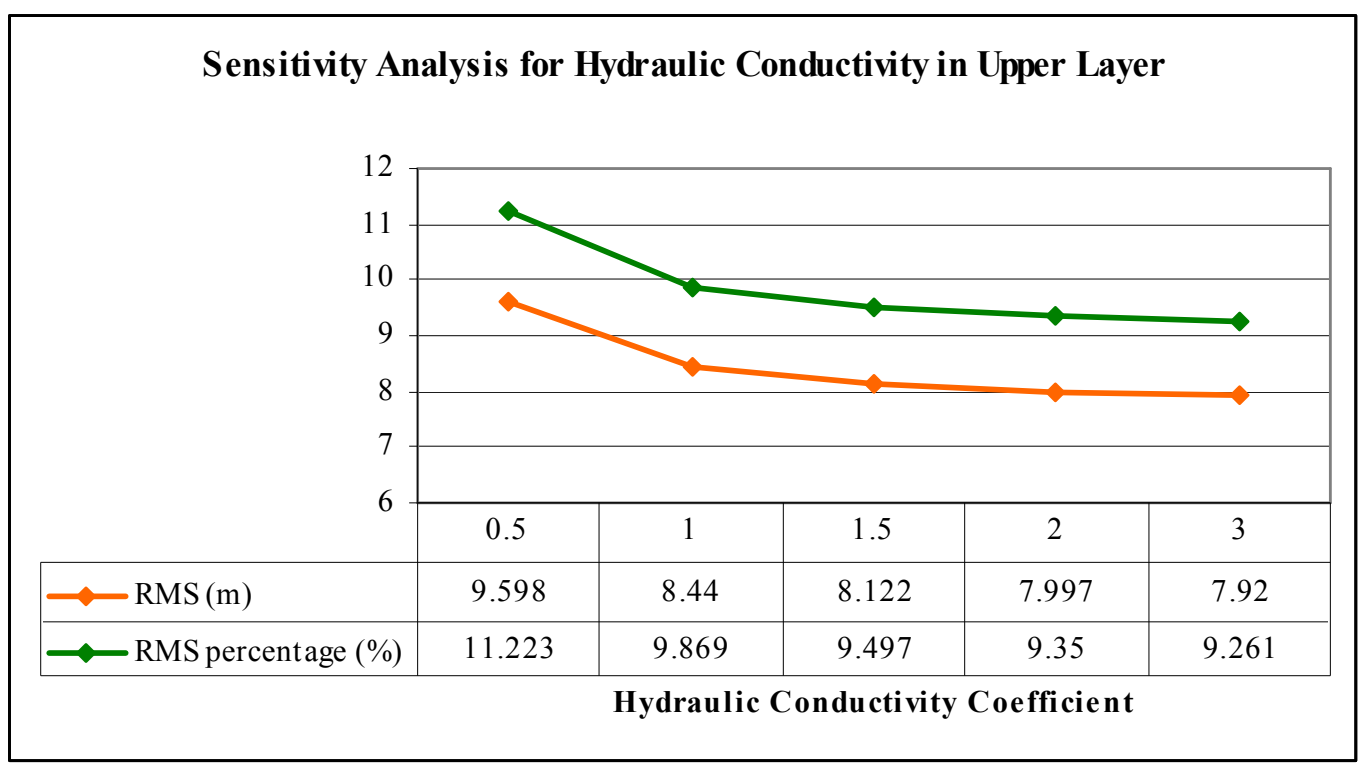

Figure 4.20: Sensitivity analysis for hydraulic conductivity in upper layer

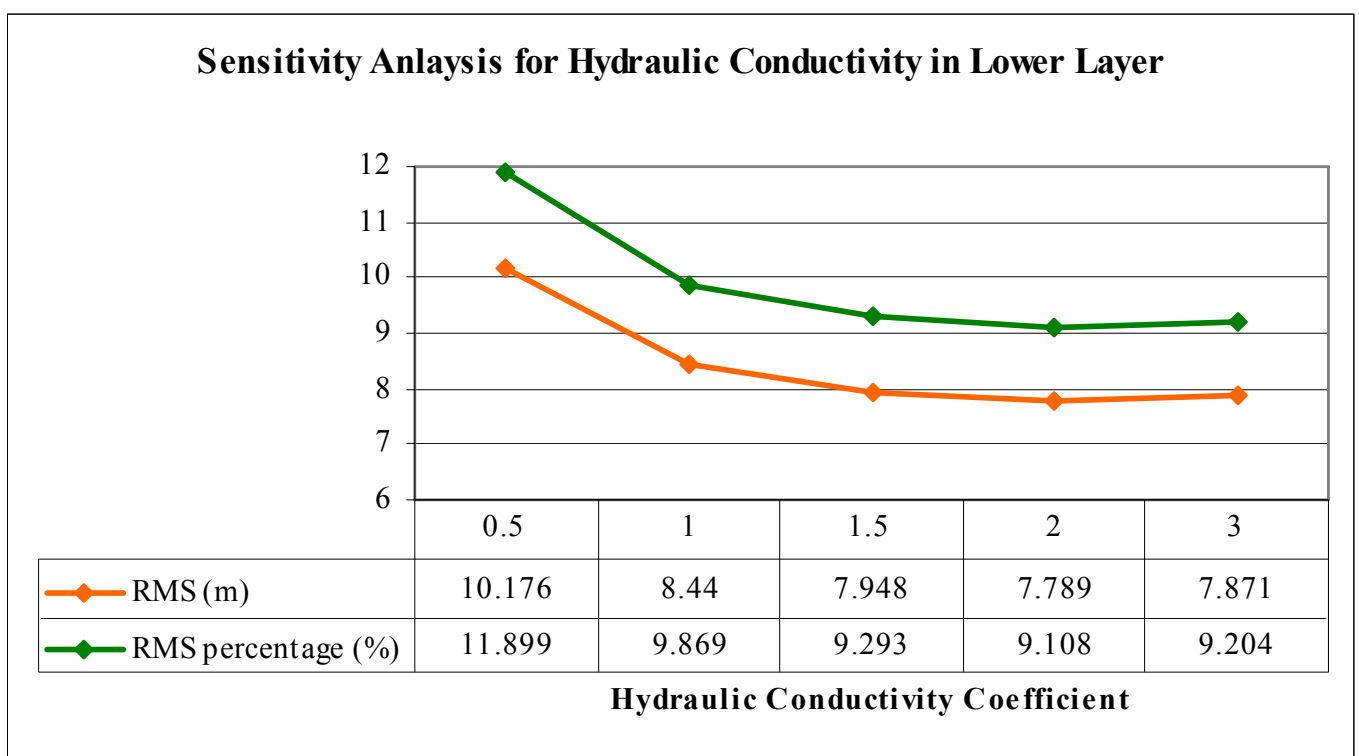

Figure 4.21: Sensitivity analysis for hydraulic conductivity in lower layer 


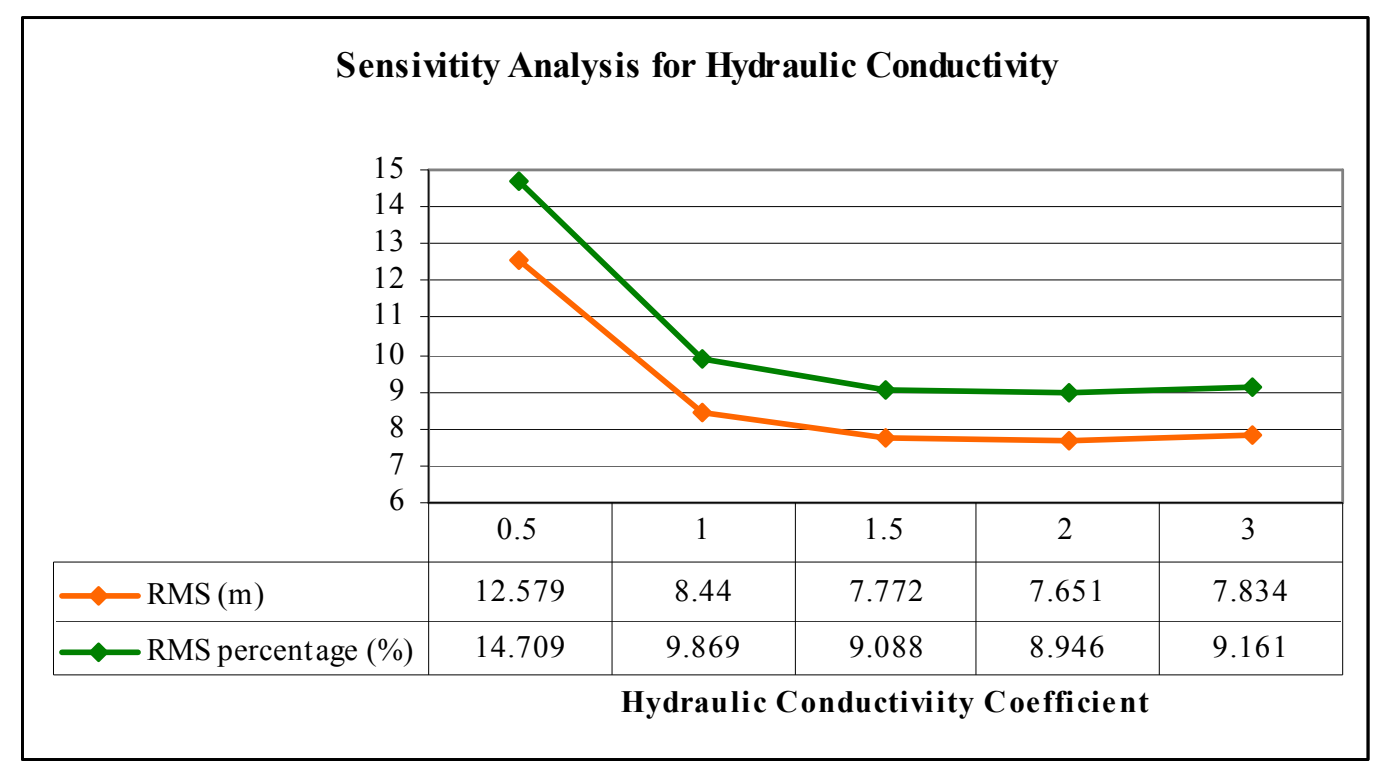

Figure 4.22: Sensitivity analysis for hydraulic conductivity in both of the layers

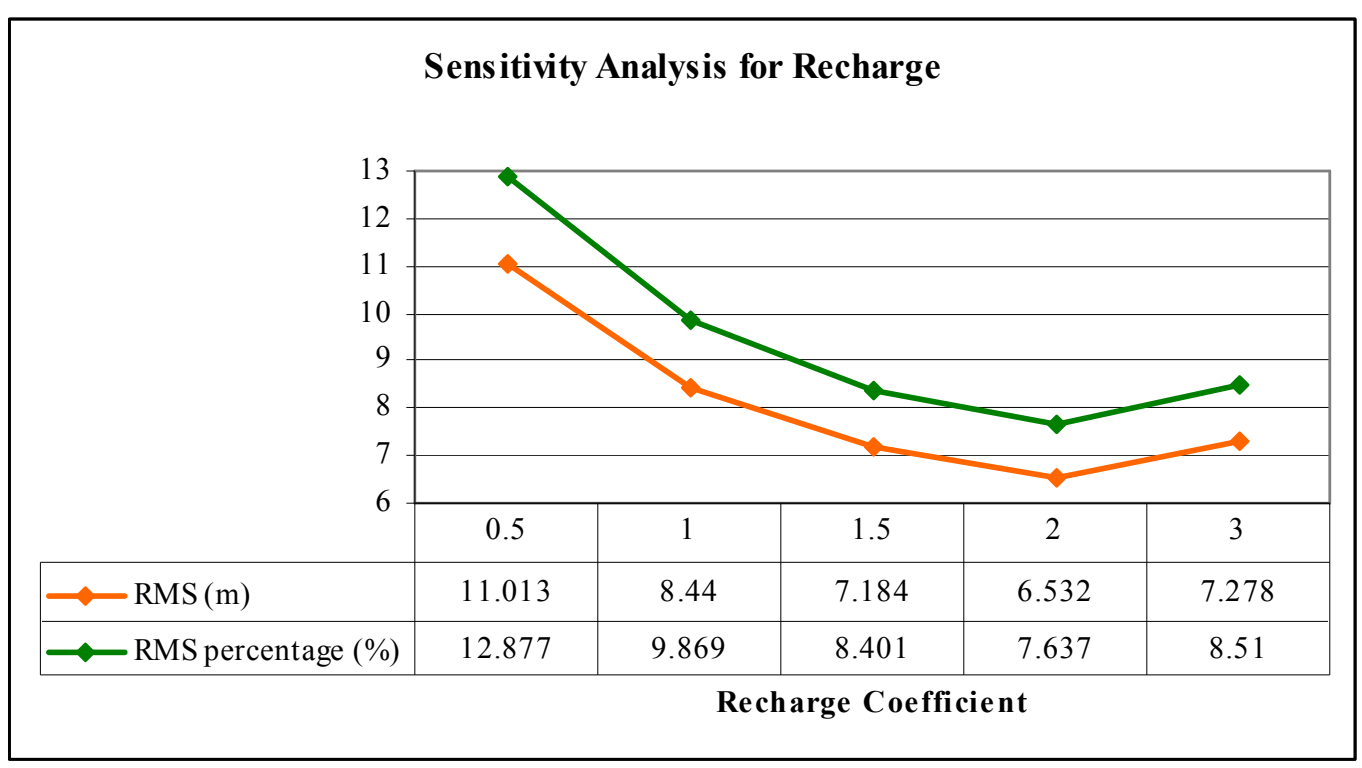

Figure 4.23: Sensitivity analysis for recharge 


\subsubsection{Groundwater Pumping Scenarios}

The calibration results indicate that the model is capable of simulating the pseudosteady state conditions observed in 1991. Some new water supply wells have been drilled in the area after 1991 and most likely these wells produced a transient state in the system since 1991. Ideally, using 1991 water levels as initial conditions a transient simulation with discharge and recharge conditions observed since 1991 should have been conducted to derive a hydraulic head distribution as of today. Unfortunately, the lack of water level and storativity data precluded this approach. Hence, assuming that today's conditions are also represented by a new steady-state, another steady-state simulation was made with the introduction of the pumping wells drilled after 1991 into the model. This simulation was necessary because it will provide a basis to analyze the impacts of the alternative mine water supply wells on the aquifer system as well as on nearby users. The new steady-state head distributions obtained by the addition of wells drilled after 1991 are shown in Figures 24 and 25 for the Quaternary and the Neogene aquifer systems, respectively.

Groundwater budget of today's steady state conditions for both Quaternary and Neogene aquifers is given in Table 4.4 and Table 4.5 , respectively. When the budgets of calibrated model and the today's model are compared, it is seen that by the additional wells, recharge from Neogene to Quaternary in southern boundary is increased. Furthermore, there is a considerable decrease in the amount of water discharged into Gediz River from groundwater system, and increase in the pumped water. For the Neogene aquifer, under flow from Kemalpaşa and recharge from Gediz River is increased slightly. Discharge of groundwater into Gölmarmara and Gediz River decreased, and pumpage from wells increased. 


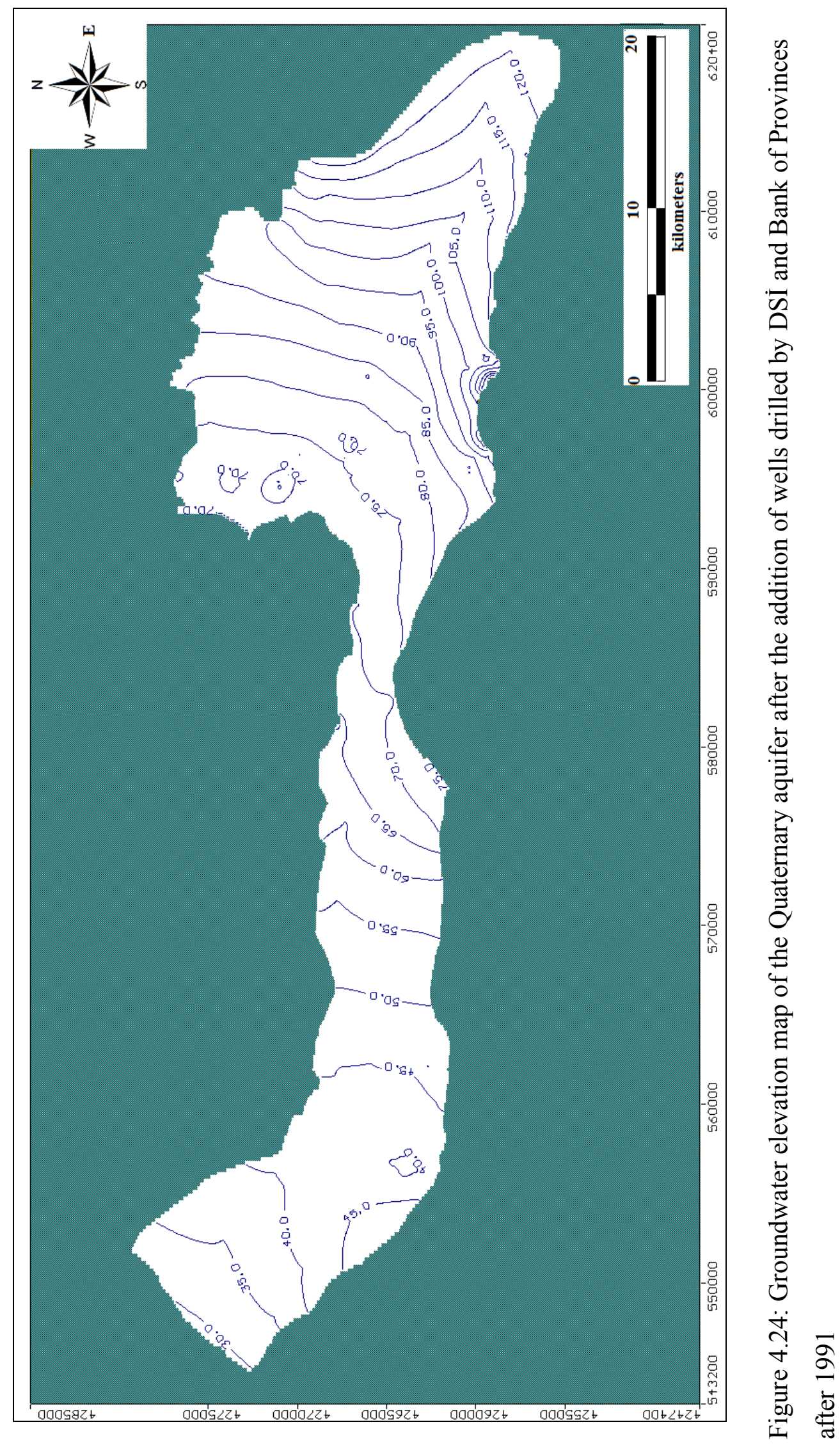




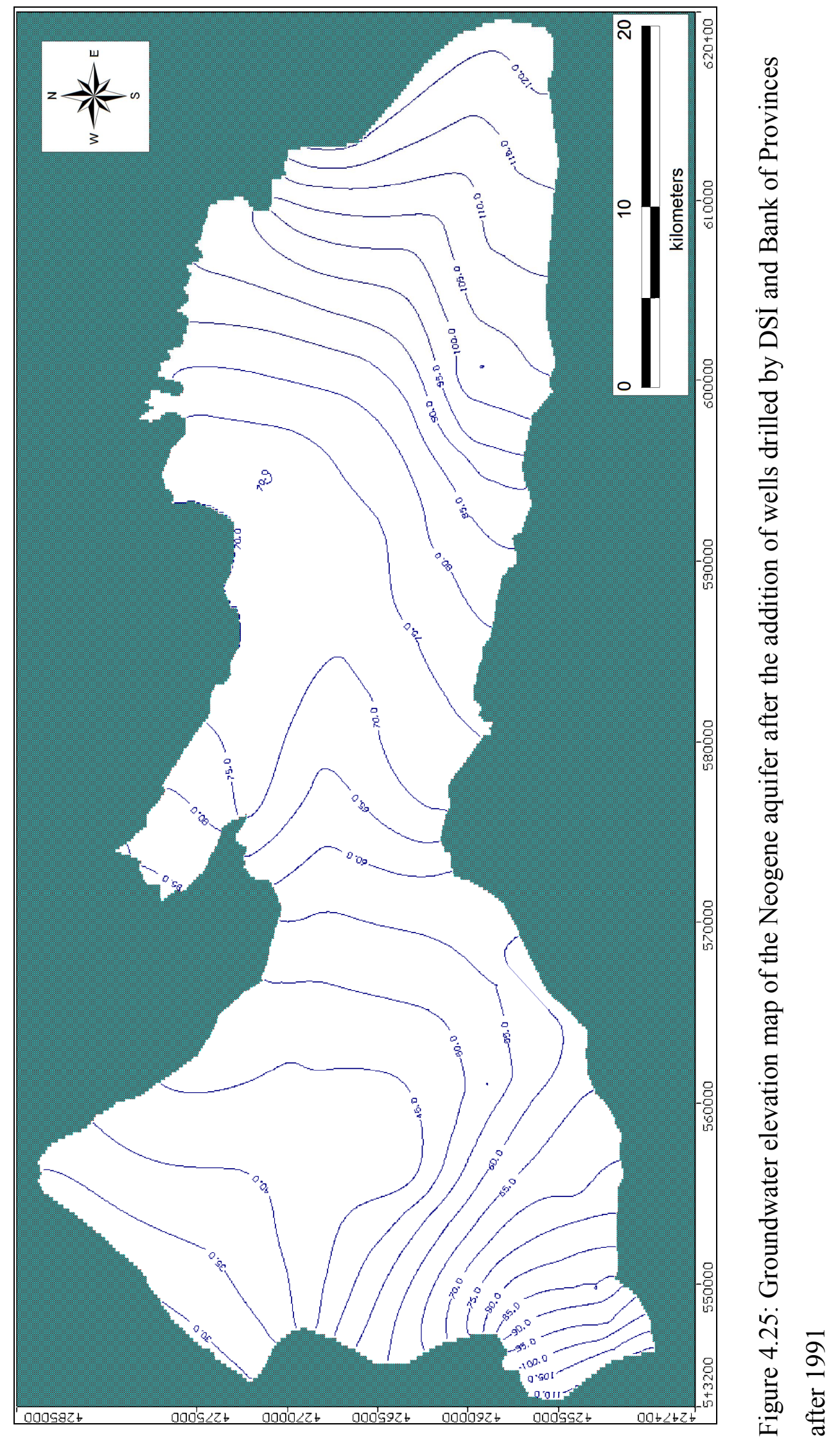


Table 4.4: Groundwater budget of Quaternary aquifer

\begin{tabular}{|c|c|c|c|}
\hline \multicolumn{2}{|c|}{ Recharge $\left(\mathrm{hm}^{3} /\right.$ year $)$} & \multicolumn{2}{c|}{ Discharge $\left(\mathrm{hm}^{3} /\right.$ year $)$} \\
\hline Under flow from Salihli & 27.75 & $\begin{array}{c}\text { Outflow from northwestern } \\
\text { boundary }\end{array}$ & 3.43 \\
\hline Recharge from rainfall & 65.39 & Wells & 131.88 \\
\hline Recharge from Gediz River & 7.68 & Discharge to Gediz River & 86.63 \\
\hline $\begin{array}{c}\text { Recharge from Neogene to } \\
\text { Quaternary in southern } \\
\text { boundary }\end{array}$ & 87.23 & Discharge to Gölmarmara & 0.24 \\
\hline $\begin{array}{c}\text { Flow from Neogene aquifer } \\
\text { to Quaternary aquifer }\end{array}$ & 73.78 & $\begin{array}{c}\text { From Quaternary aquifer to } \\
\text { Neogene aquifer }\end{array}$ & 39.65 \\
\hline Total Recharge & 261.83 & Total Discharge & 261.84 \\
\hline
\end{tabular}

Table 4.5: Groundwater budget of Neogene aquifer

\begin{tabular}{|c|c|c|c|}
\hline \multicolumn{2}{|c|}{ Recharge $\left(\mathrm{hm}^{3} /\right.$ year $)$} & \multicolumn{2}{c|}{ Discharge $\left(\mathrm{hm}^{3} /\right.$ year $)$} \\
\hline Under flow from Salihli & 7.94 & $\begin{array}{c}\text { Outflow from northwestern } \\
\text { boundary }\end{array}$ & 8.72 \\
\hline Recharge from rainfall & 60.26 & Wells & 35.44 \\
\hline Recharge from Gediz River & 2.17 & Discharge to Gediz River & 1.43 \\
\hline Under flow from Kemalpaşa & 12.91 & Discharge to Gölmarmara & 3.39 \\
\hline $\begin{array}{c}\text { Flow from Quaternary } \\
\text { aquifer to Neogene aquifer }\end{array}$ & 39.65 & $\begin{array}{c}\text { Flow from Neogene aquifer to } \\
\text { Quaternary aquifer }\end{array}$ & 73.78 \\
\hline Total Recharge & 122.94 & Total Discharge & 122.77 \\
\hline
\end{tabular}

After the generation of today's steady-state water levels, the next step was the development of pumping scenarios for the water need of the mine site to be used as process water, and evaluation of their effects to the pumping wells and the aquifers. Again, steady-state simulations were conducted with the addition of the alternative mine water supply wells into the system. Water supply requirement of the mine site to be used as process water is $135 \mathrm{~L} / \mathrm{s}$. Two scenarios were set up; for the first scenario it was assumed that all of the water was extracted from the Quaternary aquifer, and for the second one, half of the water was pumped from the Quaternary aquifer, the other half is from the Neogene aquifer. 


\subsubsection{Scenario A}

Scenario A is based on the assumption that total amount of process water, $135 \mathrm{~L} / \mathrm{s}$ is pumped from the Quaternary aquifer. The locations of these wells were determined so that they will provide least impact on existing public and private wells and that they would be closer to the mine site.

Four wells were added to the model to supply process water. Discharges of these wells were equal to each other and they are $1 / 4^{\text {th }}$ of the $135 \mathrm{~L} / \mathrm{s}$. In order to isolate the drawdown impacts of the mine water supply wells, the steady-state water levels obtained from the today's model (without the mine water supply wells) was assigned to the Scenario runs as initial head. The model was run under steady state conditions. Location of the scenario wells and the groundwater elevation map of Quaternary aquifer are given in Figure 4.26. Although these four wells penetrate into Quaternary aquifer, they have a slight affect on Neogene aquifer as well. Drawdown at the Quaternary aquifer caused by the four mine water supply wells is shown in Figure 4.27. Effect of these wells to the Neogene aquifer is not significant.

\subsubsection{Scenario B}

For the Scenario B, it was assumed that half of the required water was extracted from the Quaternary aquifer and the remaining was supplied from the Neogene aquifer. To simulate it, two wells were drilled into each of the aquifer systems. Discharges at the wells were kept uniform at a value of $33.75 \mathrm{~L} / \mathrm{s}$. As mentioned in Scenario A, locations of these wells were also determined by evaluating the same points. Locations of these wells with the groundwater head distribution after the addition of the wells are given in Figure 4.28 and Figure 4.29. Drawdown map of both Quaternary and Neogene aquifers are shown in Figure 4.30 and Figure 4.31. 


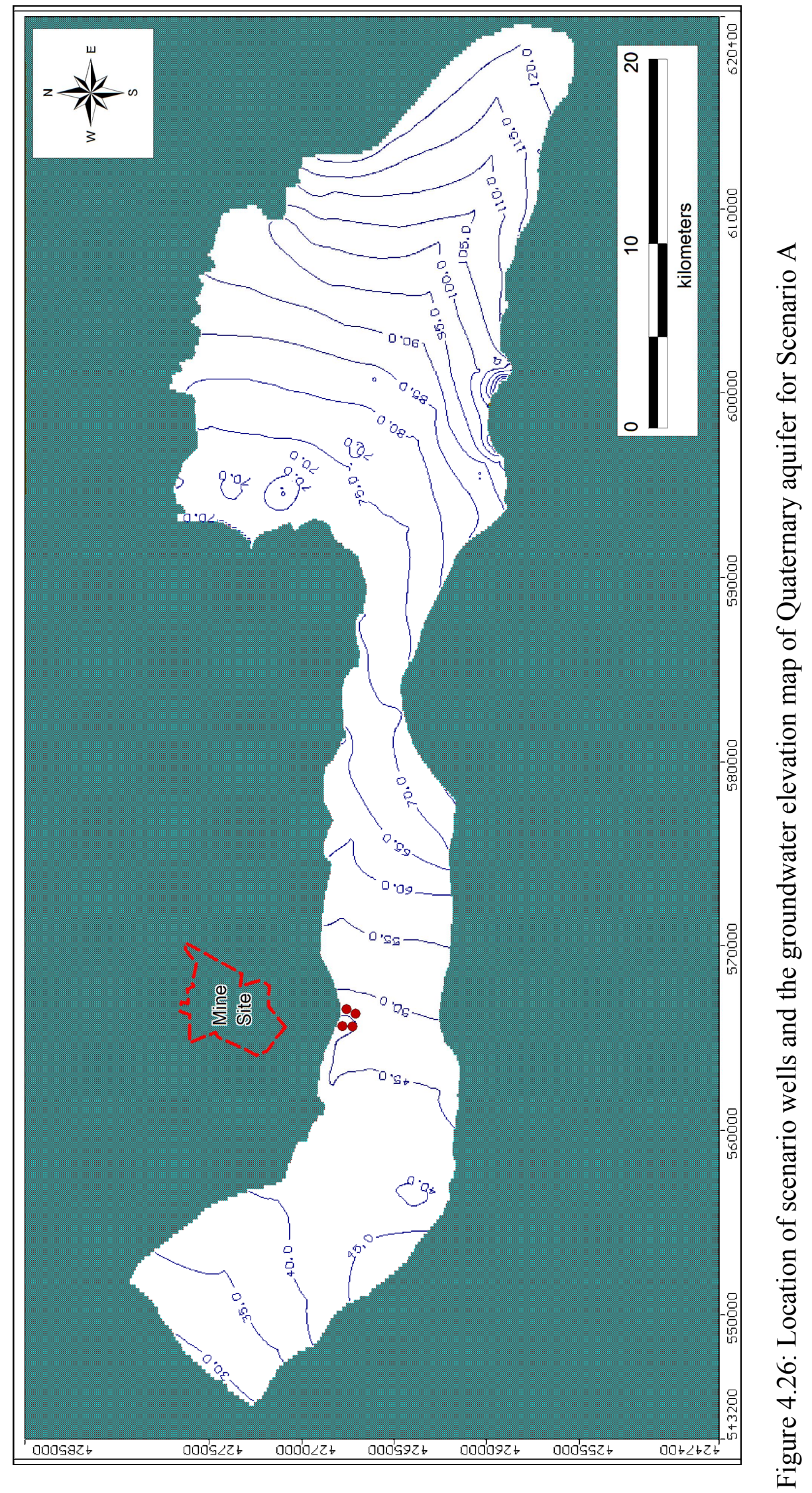




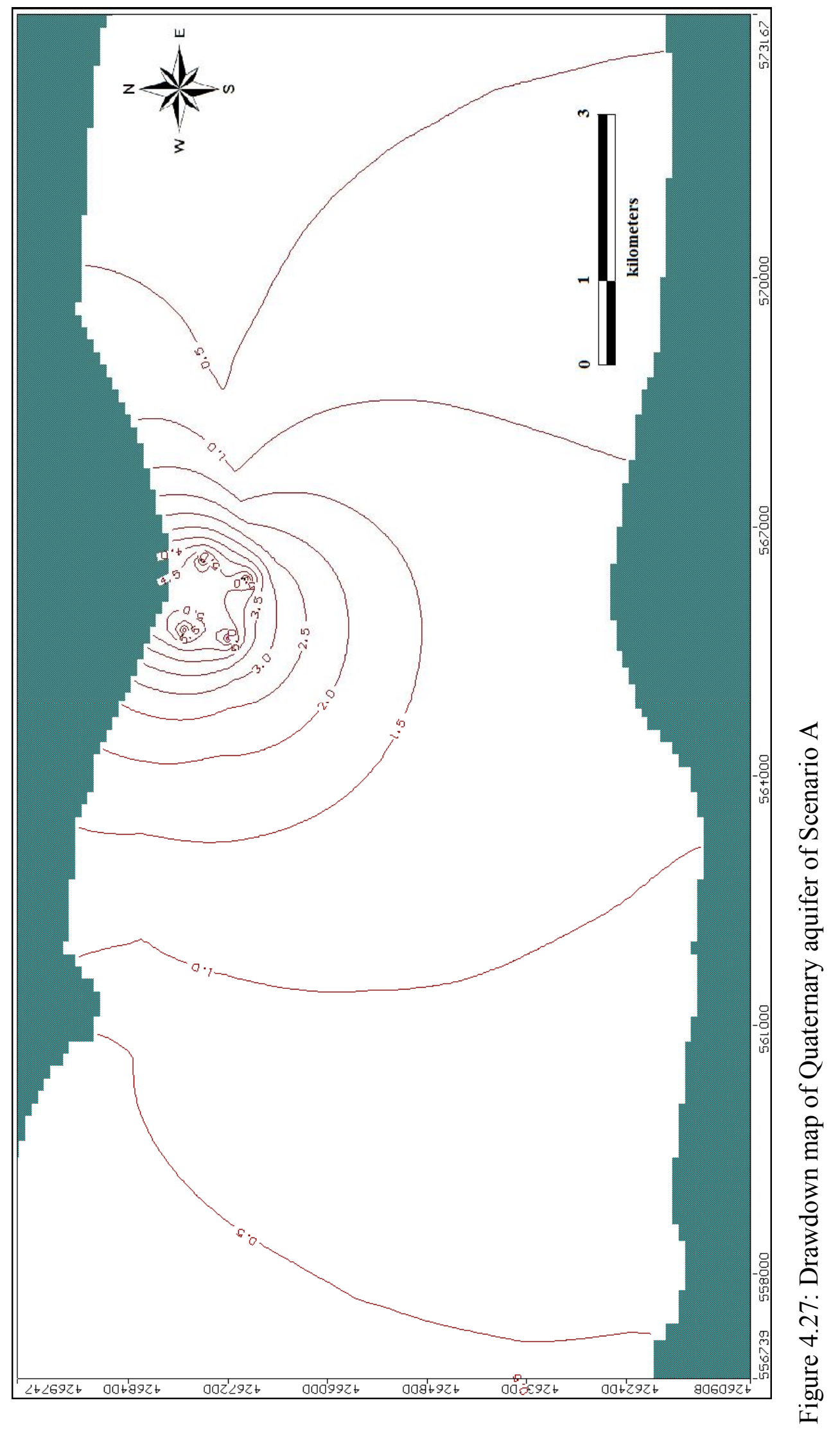




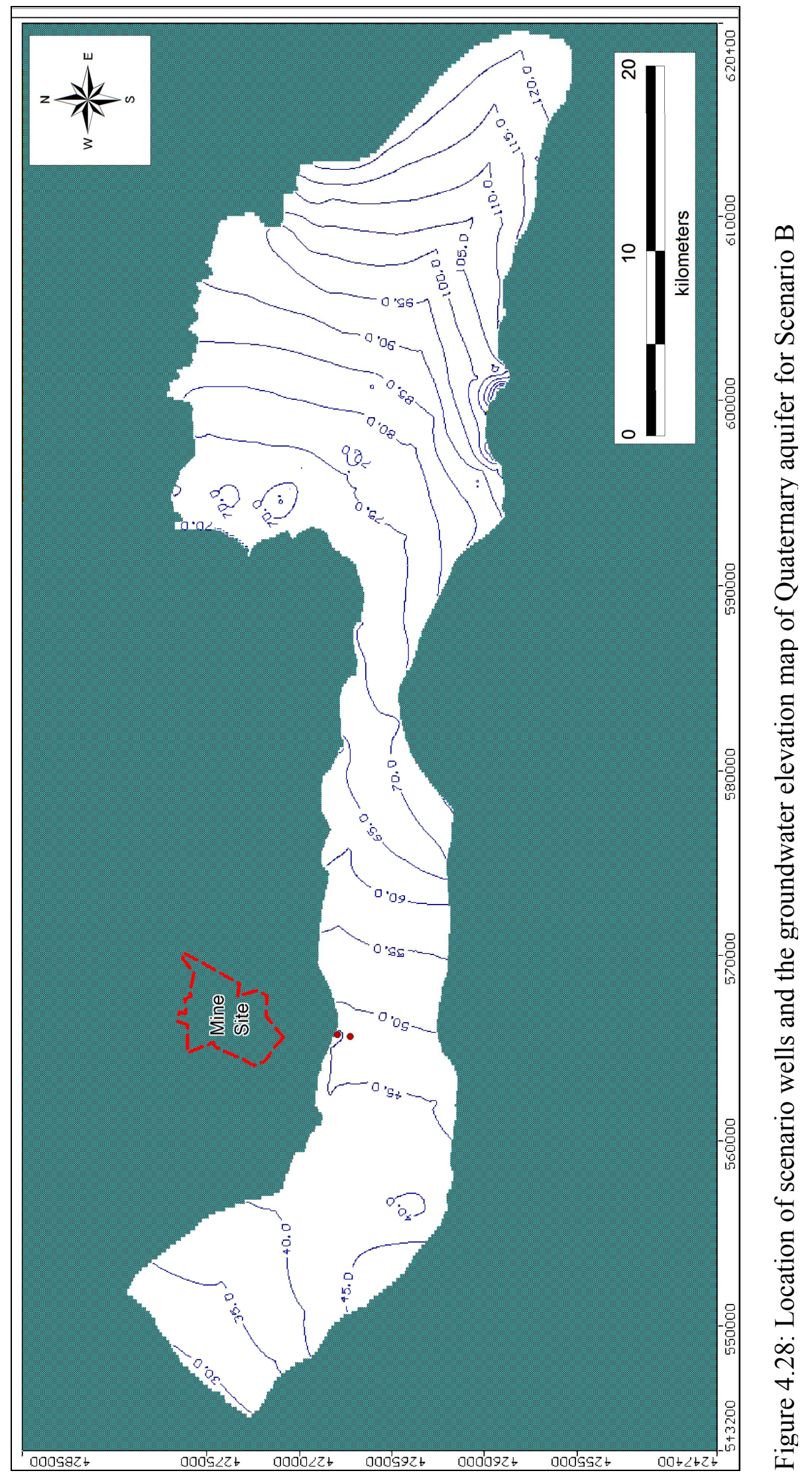




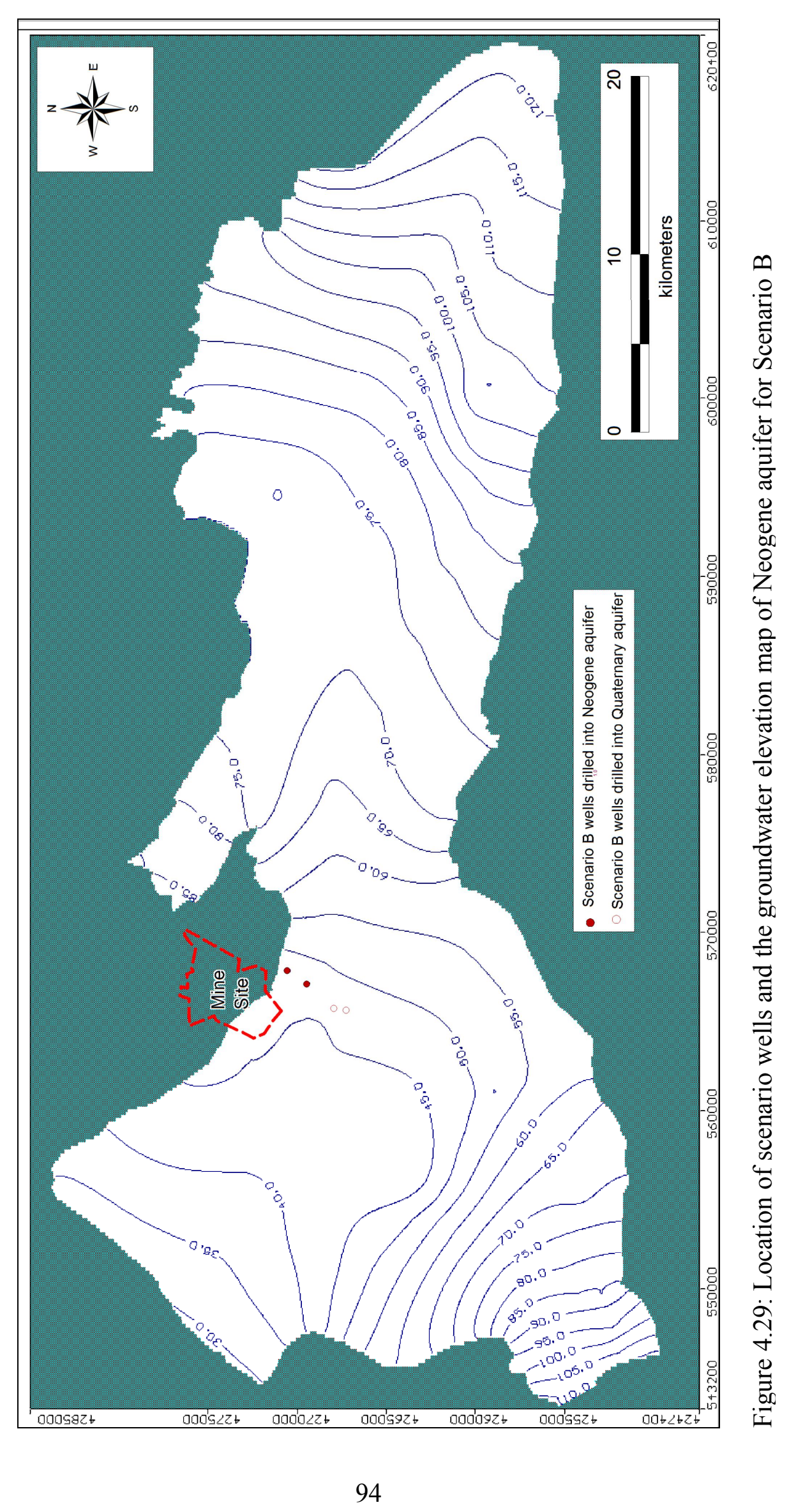




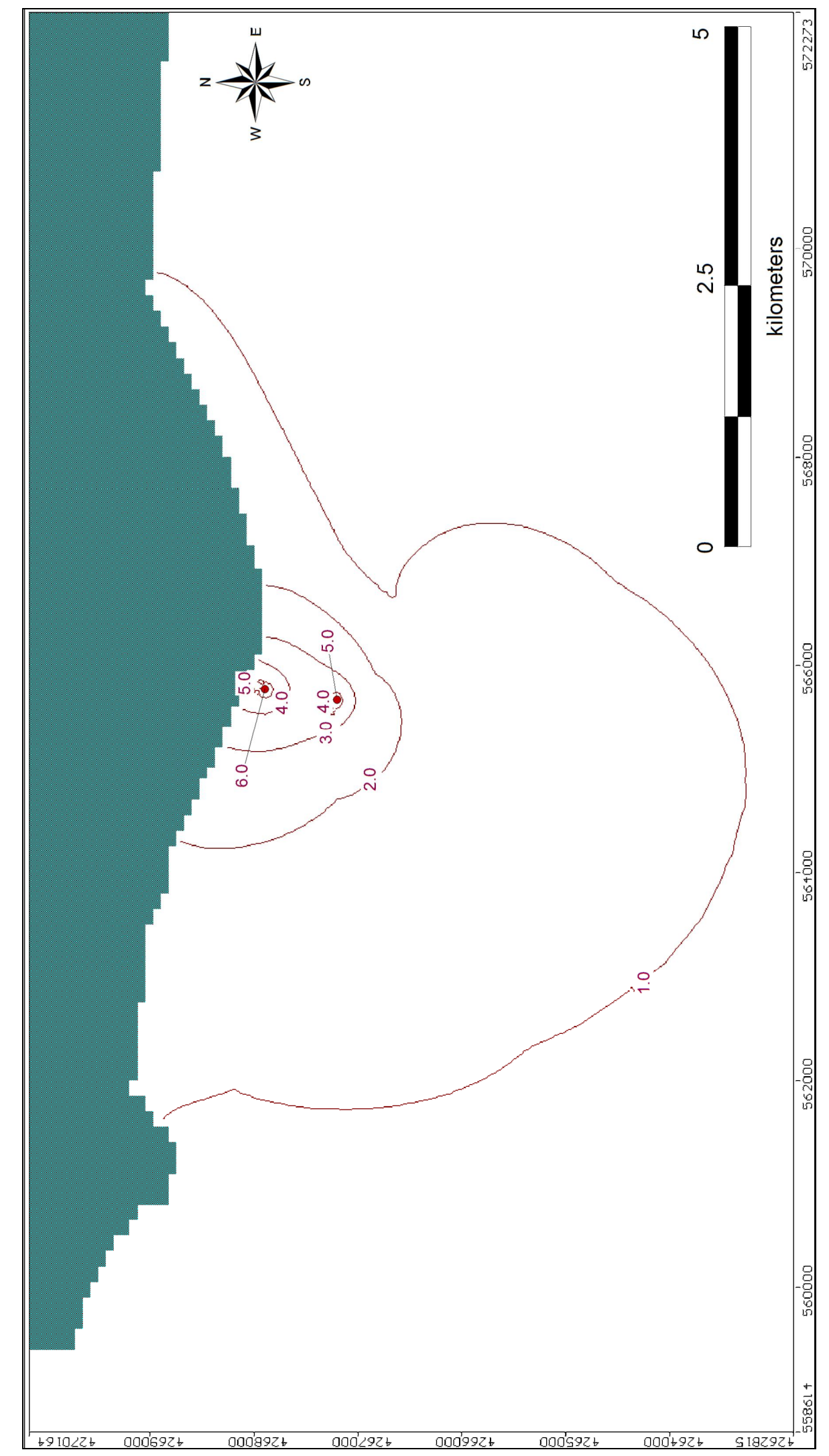

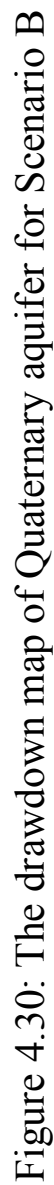




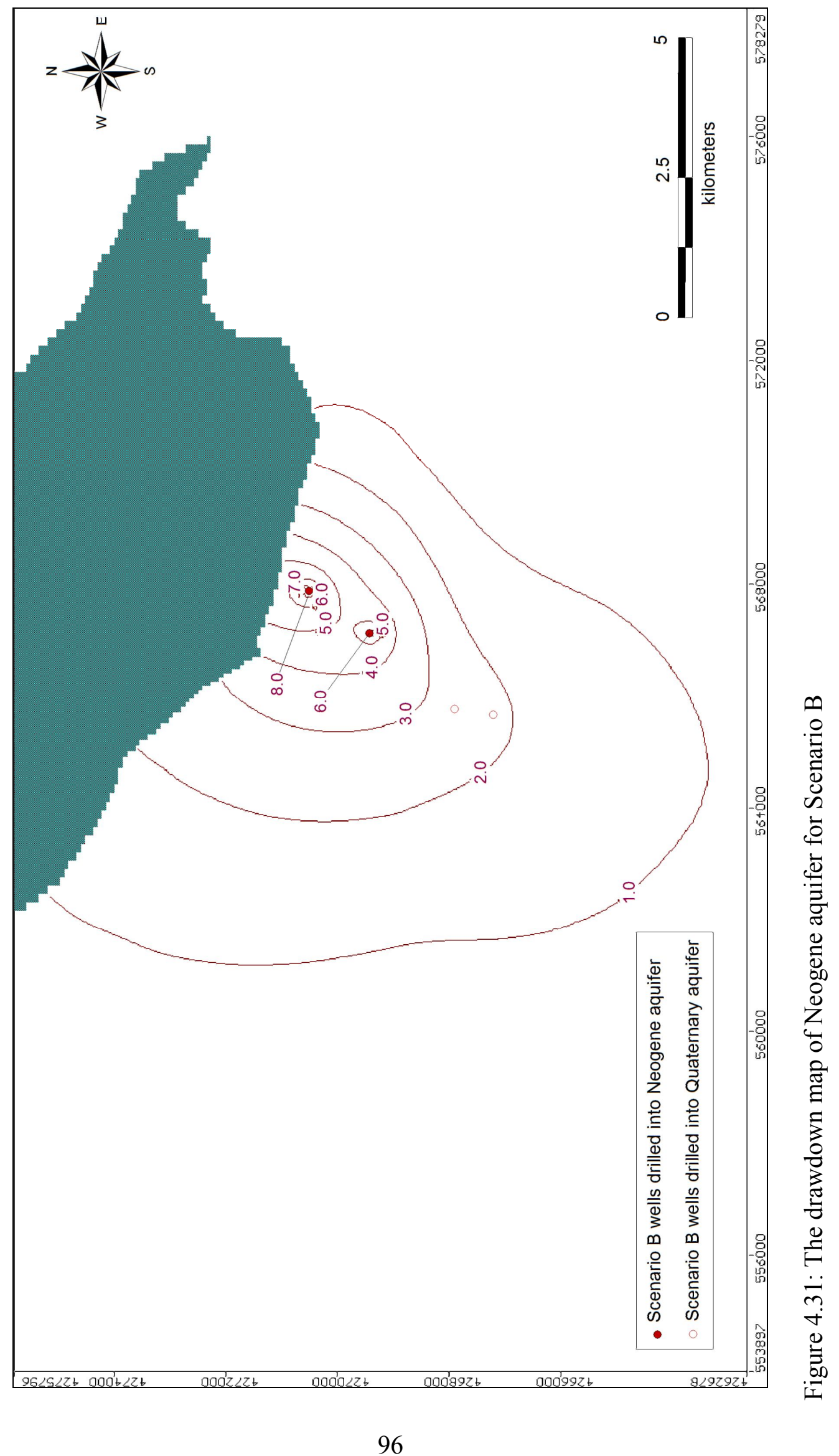




\subsection{Alternative III: Reuse of Waste Water of Turgutlu Town after Treatment}

Third alternative is the reuse of waste water of Turgutlu town after treatment. Currently, the town of Turgutlu with a population of 114,483 does not have a waste water treatment plant and discharges its waste directly into the Gediz River. Hence, it is one of the important point source of pollution for the Gediz River. Therefore, this alternative will evaluate the feasibility of using the waste water of the town of Turgutlu after they are treated. Only domestic waste water is considered in this alternative.

In this alternative, population of Turgutlu town, amount of waste water produced, and amount and quality of treated waste water should be determined. According to 2008 census results of Turkish Statistical Institute, population of Turgutlu town is 114,483 . Groundwater consumption is assumed to be $250 \mathrm{~L} /$ day/capita for Turgutlu town.

The amount of water used for domestic purposes was calculated by multiplying the population of Turgutlu town with the groundwater consumption per capita.

Amount of water used for domestic purposes $\quad=(114,483) *(250)$

$$
\begin{aligned}
& =28,620,750 \mathrm{~L} / \mathrm{d} \\
& =28,620.75 \mathrm{~m}^{3} / \mathrm{d}
\end{aligned}
$$

According to survey of Man-ar Construction and Environmental Technologies Company (2009), $80 \%$ of the domestic water turns into waste water.

The amount of waste water of Turgutlu town $\quad=(28,620.75) * 0.80$

$$
\begin{aligned}
& =22,896.6 \mathrm{~m}^{3} / \mathrm{d} \\
& =265.00 \mathrm{~L} / \mathrm{s}
\end{aligned}
$$


Second way of calculating the amount waste water of Turgutlu town is based on the amount of water pumped for domestic purposes. There are 10 wells to meet the water requirements of Turgutlu town summarized in Table 4.6. Total discharge of these wells is $332.60 \mathrm{~L} / \mathrm{s}$. $80 \%$ of this water is turned into waste water, which is 266.08 $\mathrm{L} / \mathrm{s}$.

Table 4.6: Wells drilled for domestic purposes

\begin{tabular}{|c|c|c|}
\hline Well No & Operated Institution & Discharge (L/s) \\
\hline $45 / 702$ & İller Bankas1 & 51.00 \\
\hline $22(3)$ & İller Bankas1 & 69.00 \\
\hline $45 / 716$ & İller Bankas1 & 27.60 \\
\hline $45 / 708$ & İller Bankas1 & 20.00 \\
\hline $45 / 191$ & İller Bankas1 & 40.00 \\
\hline $45 / 192$ & İller Bankas1 & 32.00 \\
\hline $45 / 193$ & İller Bankas1 & 40.00 \\
\hline $45 / 194$ & İller Bankas1 & 30.00 \\
\hline 1014 & DSİ & 18.00 \\
\hline B-45/17291 & DSI & 5.00 \\
\hline \multicolumn{2}{|c|}{ Total Discharge (L/s) } & 332.60 \\
\hline \multicolumn{2}{|c|}{}
\end{tabular}

Therefore, as it is seen from both of the analysis, the amount of waste water is approximately $265 \mathrm{~L} / \mathrm{s}$ which is almost twice as the water requirement of mine site. Location the Turgutlu waste water treatment plant mentioned in the feasibility report of Man-ar Construction and Environmental Technologies Company (2009) is given in Figure 4.32.

After the treatment process, according to Urban Wastewater Treatment Directive published by Ministry of Environmental and Forestry (2006), the treatment capacity of the waste water treatment plants should be given in Table 4.7.

Table 4.7: Treatment capacity of Turgutlu Waste Water Treatment Plant

\begin{tabular}{|c|c|}
\hline Parameter & Minimum treatment efficiency \\
\hline $\begin{array}{c}\left.\text { Biochemical oxygen demand (BOD }{ }_{5}\right) \\
(\mathrm{mg} / \mathrm{L})\end{array}$ & $70-90 \%$ \\
\hline Chemical oxygen demand (COD) $(\mathrm{mg} / \mathrm{L})$ & $75 \%$ \\
\hline Total suspended solids $(\mathrm{mg} / \mathrm{L})$ & $70-90 \%$ \\
\hline
\end{tabular}




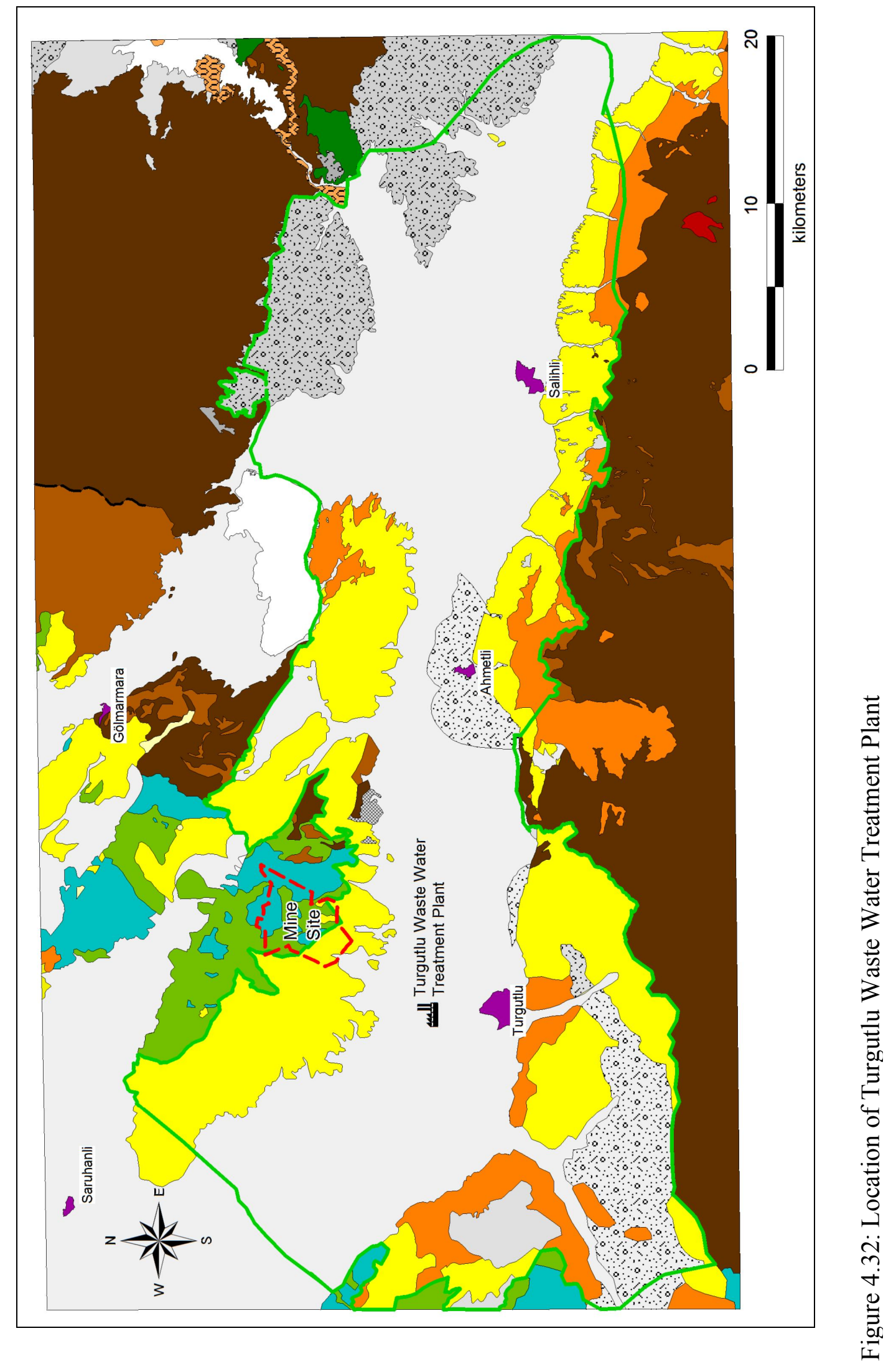




\section{CHAPTER 5}

\section{DISCUSSION, SUMMARY AND CONCLUSIONS}

\subsection{Discussion of Alternatives}

In Chapter 4, three alternatives sources to meet the process water requirement of the mine site were explained. First alternative is the supply of water from Gediz River, second alternative is the pumping from Turgutlu-Salihli aquifer, and final one is the reuse of waste water of Turgutlu town after treatment.

Evaluation of the Gediz River flow rates at a nearby station and the low flow analyses conducted indicate that the Gediz River should not be relied upon as the source of process water supply in dry season (June through September). This is because of the probability that the longest duration in which flows are lower than a critical base value necessary for low flow requirements $\left(0.5 \mathrm{~m}^{3} / \mathrm{sec}\right)$ being greater than 15 days is relatively high (about 30\%). This analysis was based on 13 years of data which did not include the dry spell that is encountered within the last few years. In fact, the visual inspection during the short period of the current study showed that the Gediz River was completely dry for more than 60 days in the summer of 2008. Therefore, surface water can not be the sole source of water required for the mining processes. Moreover, Gediz River water should be treated because it is highly polluted (Figure 5.1). 


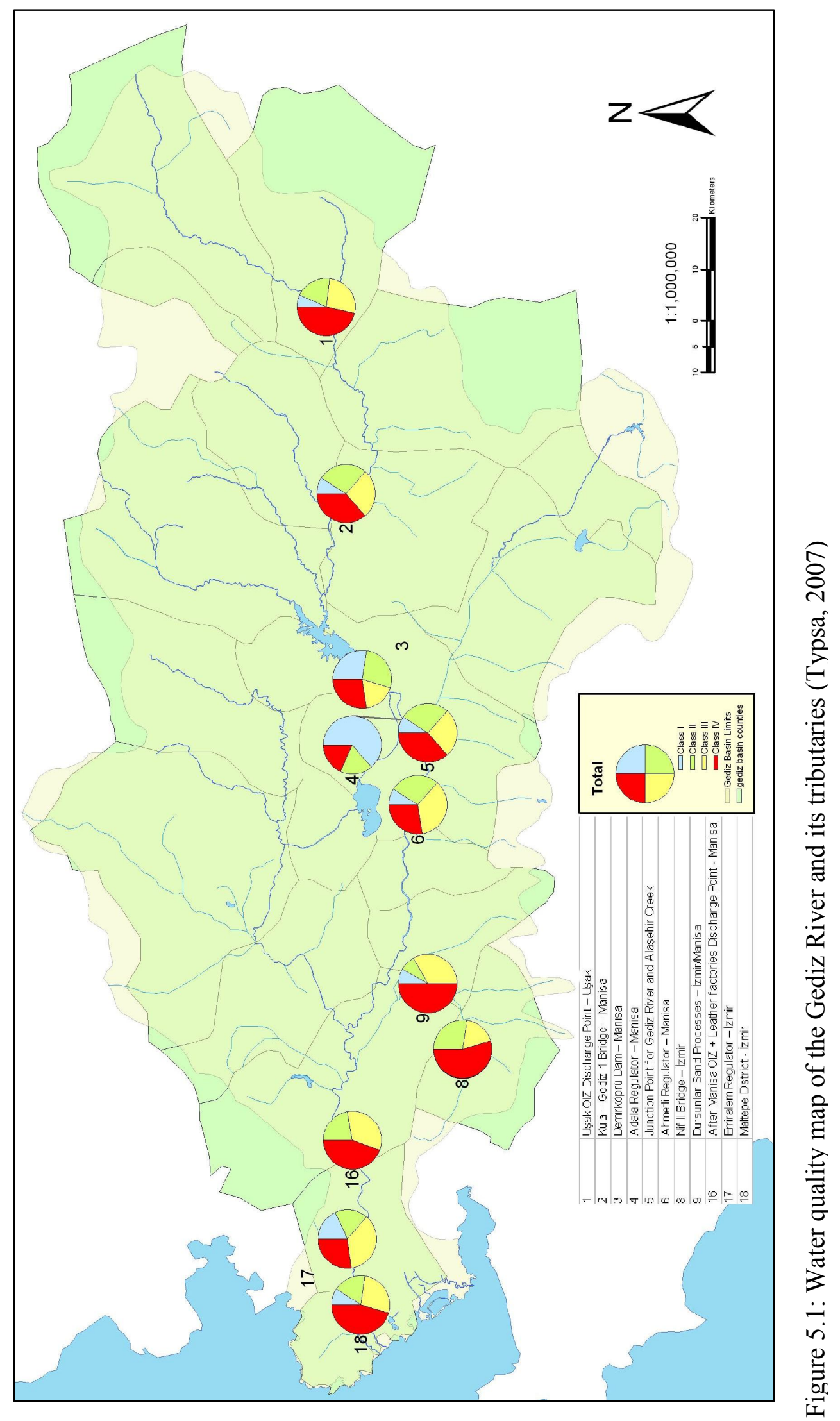


Providing the process water required for the mine site from Turgutlu-Salihli aquifer is the second alternative. In the scope of this alternative, two potential scenarios (Senario A and Senario B) were considered, and their effects on the aquifer systems were evaluated. In Scenario A, it was assumed that all of the required water (i.e., 135 $\mathrm{L} / \mathrm{s}$ ) was extracted from the Quaternary aquifer. Four wells, each having the same discharge rate, were added to the model to simulate the effects of these wells to other wells around them. The pumpage from these wells created a large cone of depression extending several kilometers from the mine water supply wells (Figure 5.2). Consequently, a large number of private wells (i.e., about 500) are affected by pumpage from the mine water supply wells. The drawdowns created at the private wells ranged between $0.5 \mathrm{~m}$ and $3 \mathrm{~m}$. Wells of Scenario A cause drawdowns that are smaller than $1 \mathrm{~m}$ at water supply wells of Turgutlu town as seen in Figure 5.2. Impacts to the Neogene aquifer are negligible; therefore, drawdowns in this layer are not displayed.

In the Scenario B, the required water was pumped from four wells in Quaternary and Neogene aquifers, discharge of each well being equal to $33.75 \mathrm{~L} / \mathrm{s}$. Two of these wells penetrated into Quaternary aquifer and the other two into Neogene aquifer. Resulting cone of depression in Quaternary aquifer extending nearly 5 kilometers from the mine water supply wells is relatively smaller than the one in Neogene aquifer. In Quaternary aquifer, nearly 100 private wells are under the effect of pumpage from mine water supply wells (Figure 5.3) and the maximum drawdown at these wells is $3 \mathrm{~m}$. In the Neogene aquifer, approximately 50 private wells are affected by the mine water supply wells and the drawdowns at private wells ranged between $1 \mathrm{~m}$ and $4 \mathrm{~m}$ (Figure 5.4) 


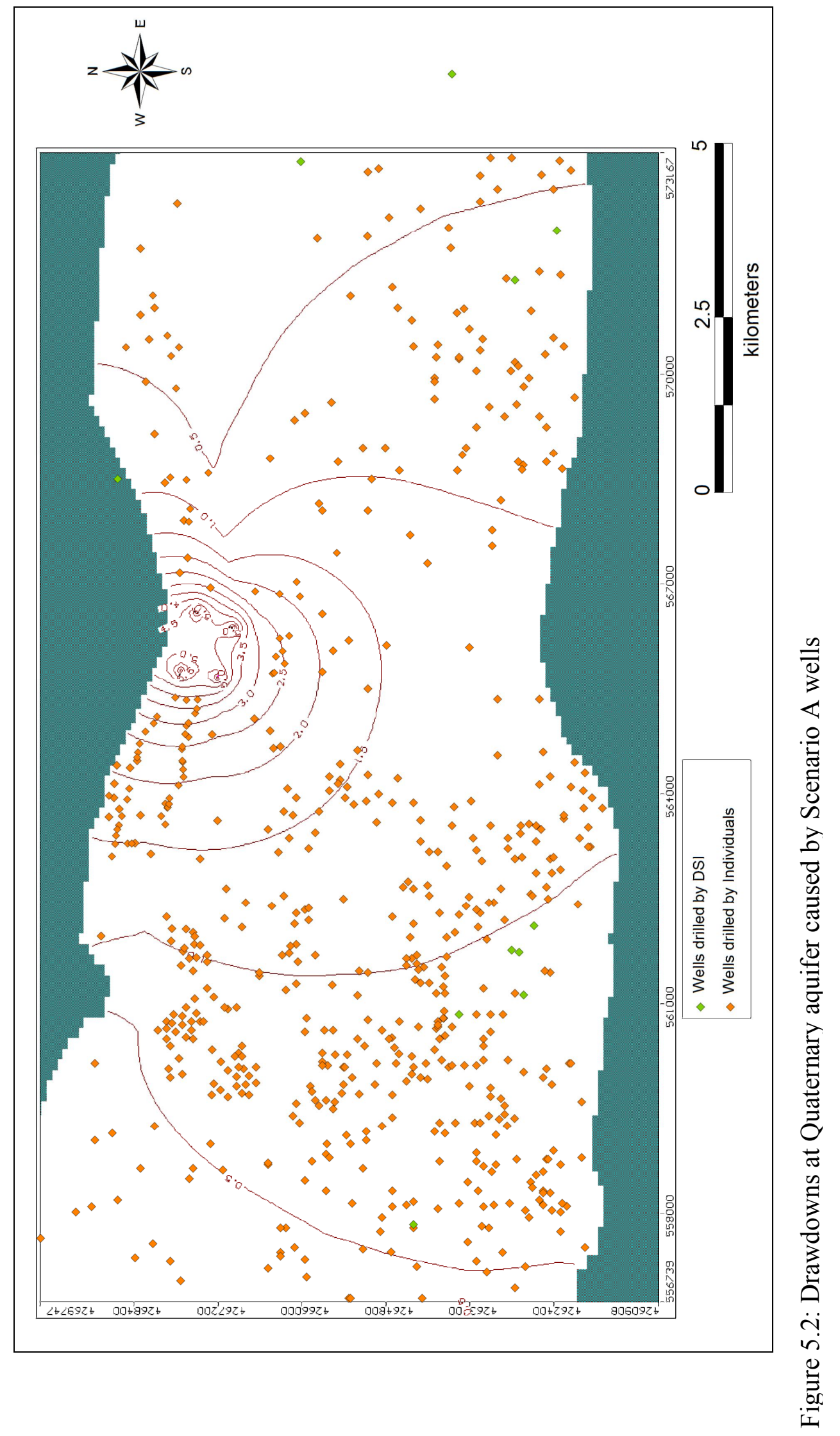




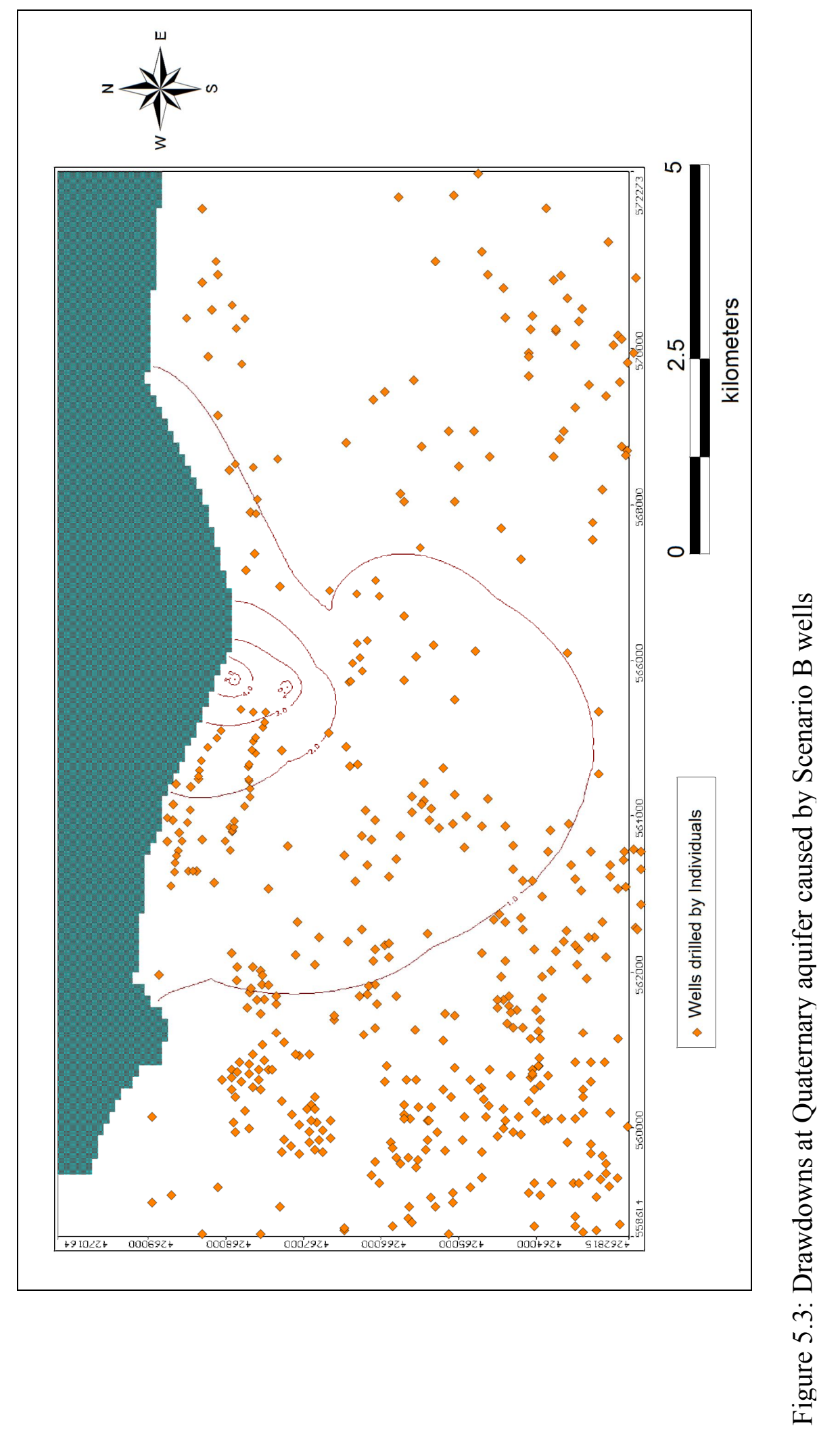




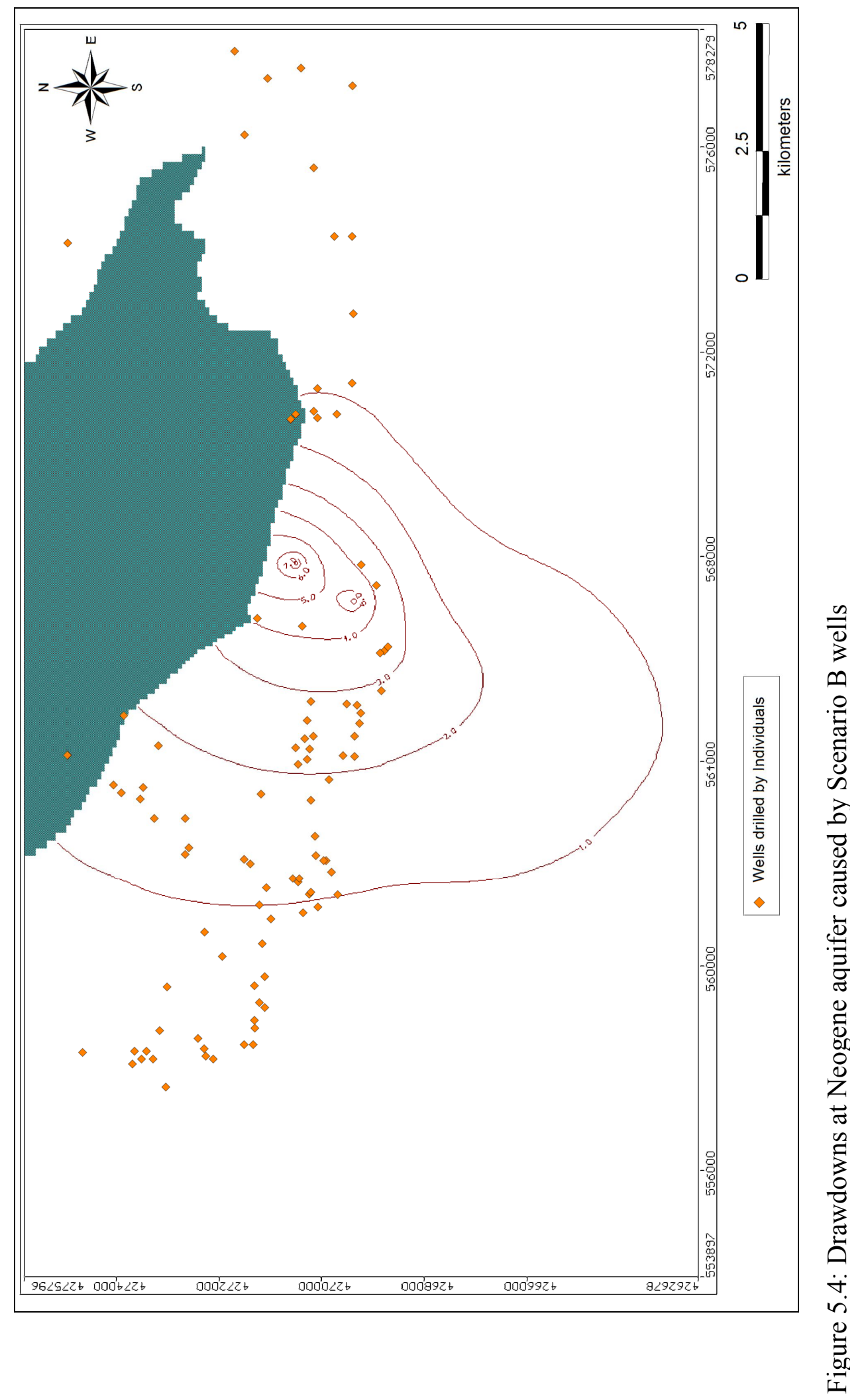


The results of the alternatives of obtaining mine water supply requirements from the groundwater system alone (Scenarios A and B) indicated that the groundwater system should not be considered as the sole source of water supply for the mine site despite its good quality. Groundwater is a very vital resource for the people living in and around the study area in meeting their drinking and irrigation water needs due to its good quality. Thus, the results of Scenario A and B showed that because of the large number of wells under the influence of the mine water supply wells, source of the mine process water should not be the groundwater alone.

The results of both surface water and groundwater alternatives indicated that they should not be the source for the process water alone. Then, studies were focused on new scenarios involving the combination of surface water and groundwater. In the Environmental Impact Assessment Report prepared for Çaldağ Project by ENCON (2005), the combination of surface water and groundwater scenarios were suggested. It was suggested that $100 \mathrm{~L} / \mathrm{s}$ of the water will be provided from the Gediz River, and the remaining $35 \mathrm{~L} / \mathrm{s}$ will be pumped from the groundwater system. This scenario was simulated with two different well designs (Sub alternative 1 and 2) explained in the following.

For sub alternative 1, three wells penetrating into Neogene aquifer were added to the system to obtain $35 \mathrm{~L} / \mathrm{s}$ water. Discharges of two of the wells were $14 \mathrm{~L} / \mathrm{s}$ each and discharge of other one was $9 \mathrm{~L} / \mathrm{s}$. The cone of depression due to pumpage from these wells extends nearly $3 \mathrm{~km}$ from the mine water supply wells. Drawdowns at the private wells in the Quaternary aquifer are negligible. However, maximum drawdown at private wells in the Neogene aquifer is $2 \mathrm{~m}$ (Figure 5.5). For the second sub alternative, only one well having $35 \mathrm{~L} / \mathrm{s}$ discharge rate was added to the Quaternary aquifer. Extension of the cone of depression is smaller than $1 \mathrm{~km}$ from the mine water supply well. Maximum drawdown created by the mine water supply well was $2.5 \mathrm{~m}$, but none of the private wells were affected (Figure 5.6). It should be noted that the model calculated drawdowns are average values over rather large cells 
and does not represent point well drawdowns. Although the pumpage from the mine water supply wells does not have significant impacts on the existing wells, scenarios mentioned in the report of ENCON (2005) are not feasible because in dry seasons $100 \mathrm{~L} / \mathrm{s}$ water can not be supplied from the Gediz River due to low flow requirements. As a result, the Gediz River can be relied on to meet the water requirements of the mine site in wet seasons only (October through May). In dry seasons (June through September), total amount of water required for the mining processes should be provided from the groundwater system.

In dry seasons, the source of water supply should be either the groundwater system or the storage of the Gediz River water in wet season in a storage reservoir with enough capacity to be used as the source of water in dry season, or combination of both. Therefore, the scenarios mentioned in the report of ENCON (2005) were slightly modified, and sub alternative 3 was developed. In this alternative, it was assumed that in wet seasons $100 \mathrm{~L} / \mathrm{s}$ of the water was supplied from the Gediz River and the remaining $35 \mathrm{~L} / \mathrm{s}$ was obtained from pumping wells. For the dry seasons, all of the required water was supplied from the groundwater system. For this alternative, four wells having same discharge rates were added to the system; two of them were in the Quaternary aquifer and the other two were in the Neogene aquifer. The extension of the cone of depression in the Neogene aquifer caused by these four wells is relatively larger than the one in the Quaternary aquifer. Drawdowns caused by the mine water supply wells at each layer are shown in Figure 5.7 and Figure 5.8. Although the number of private wells in the Quaternary aquifer affected by the mine water supply wells is more than the ones in the Neogene aquifer, maximum drawdown calculated at each layer is no more than $2 \mathrm{~m}$. Therefore, the mine water supply wells do not have significant impacts on the groundwater system and the existing wells. However, the usage of extensive amount of groundwater particularly in the dry season is the negative side because many people depend on the groundwater system in this season to meet their irrigation requirements. 


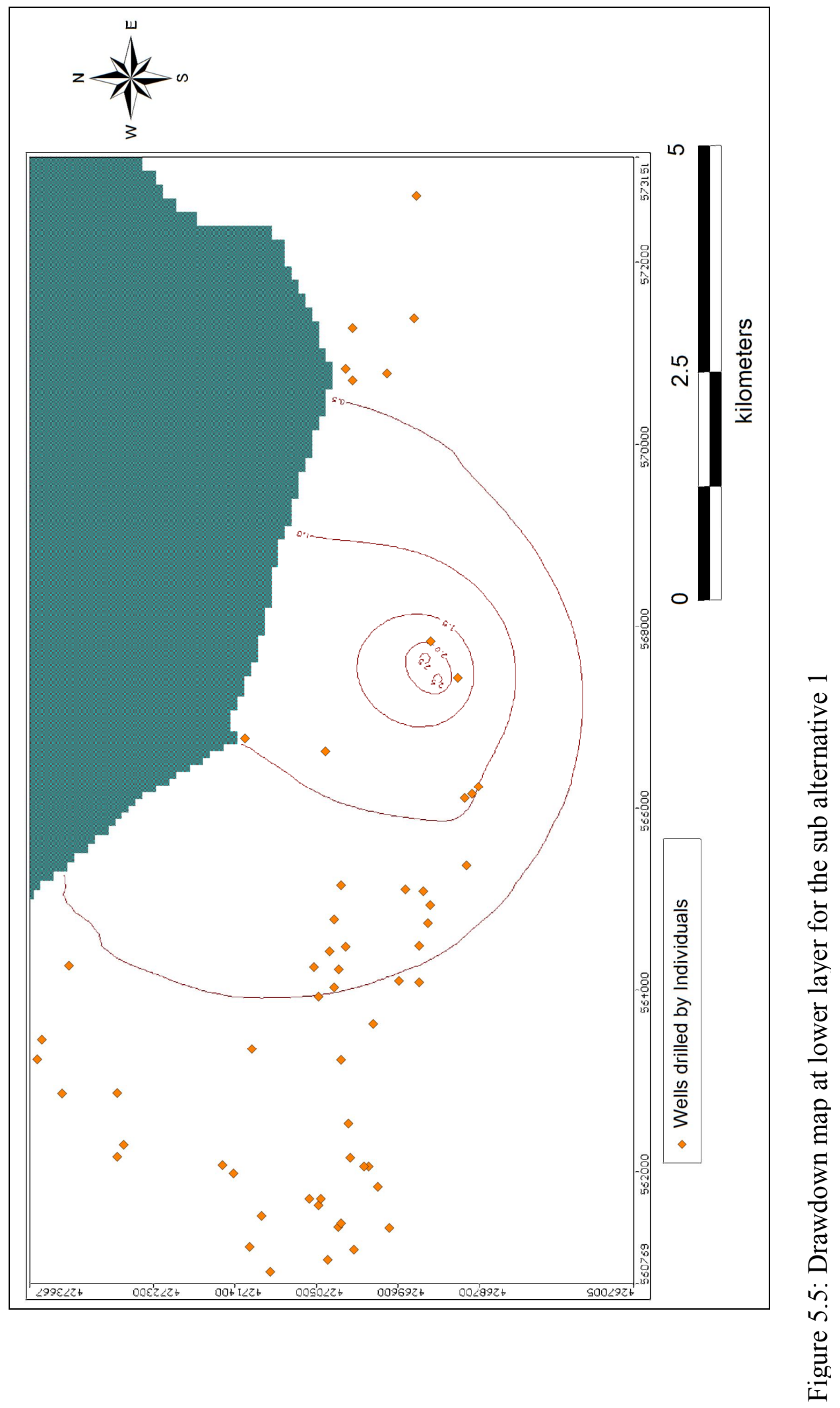




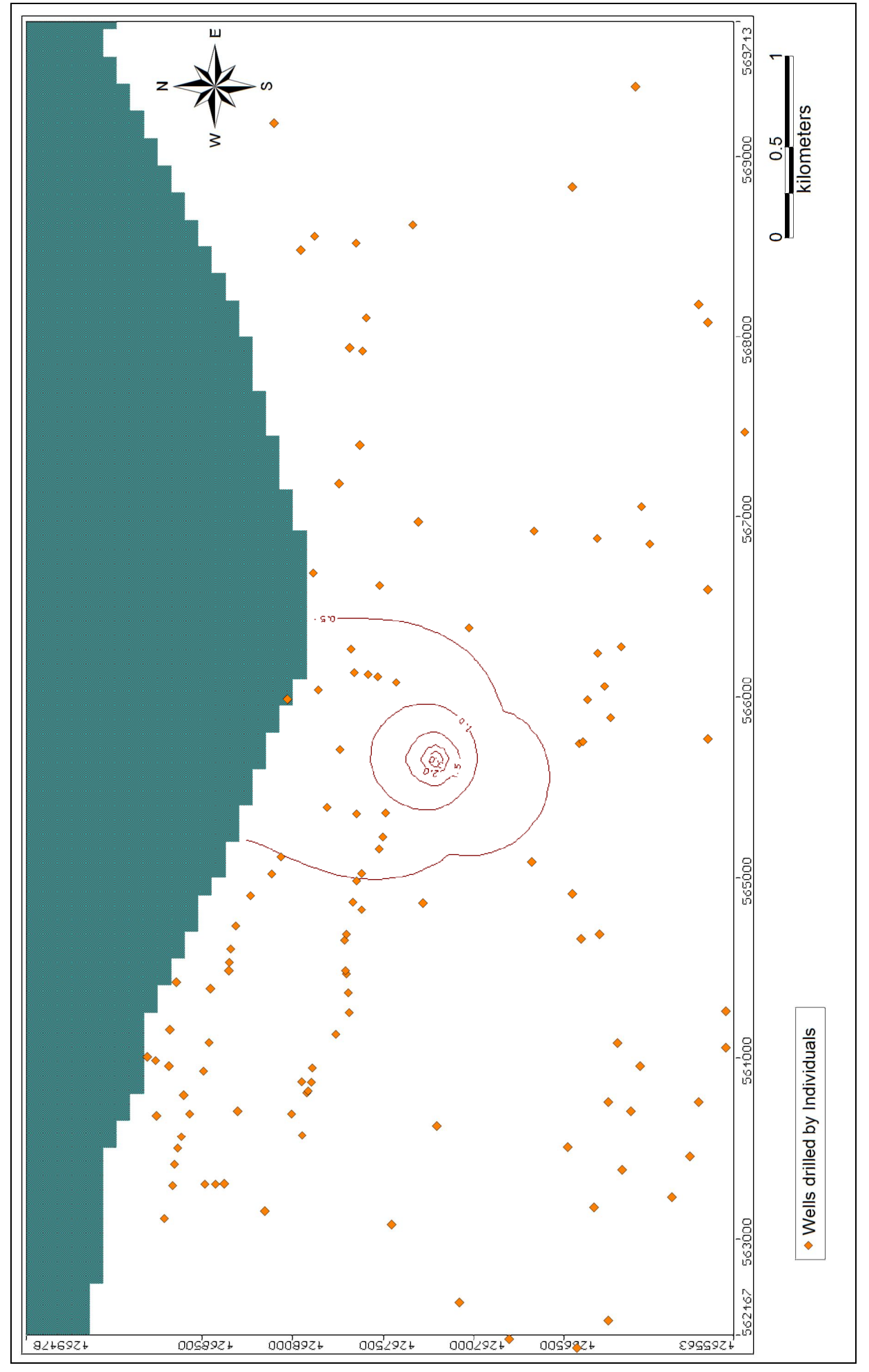

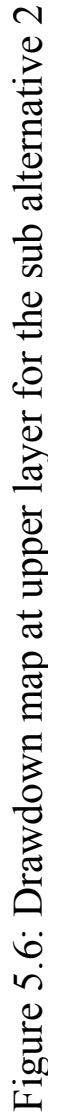




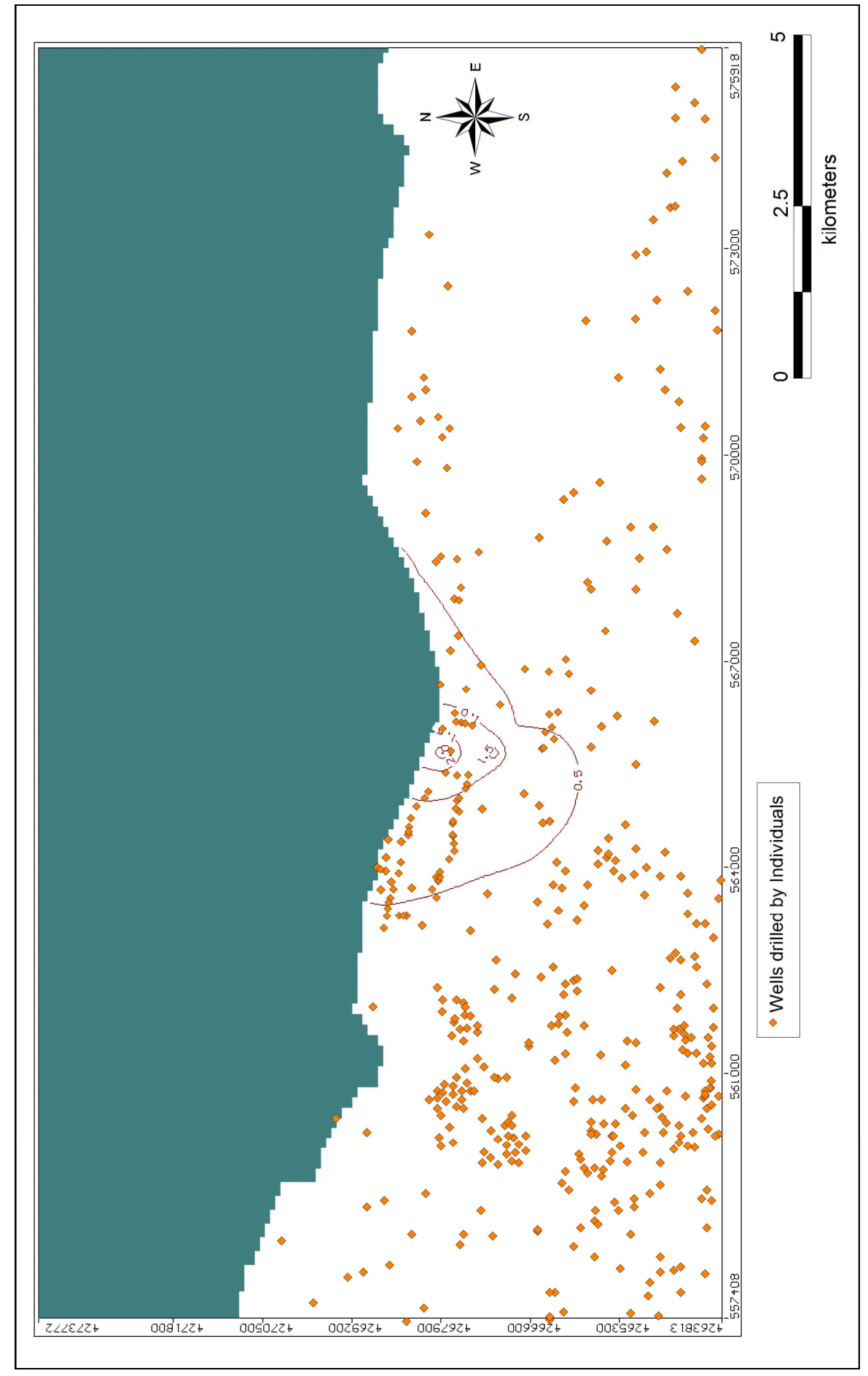

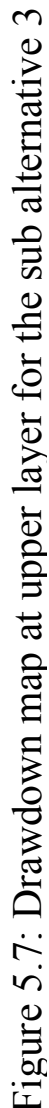




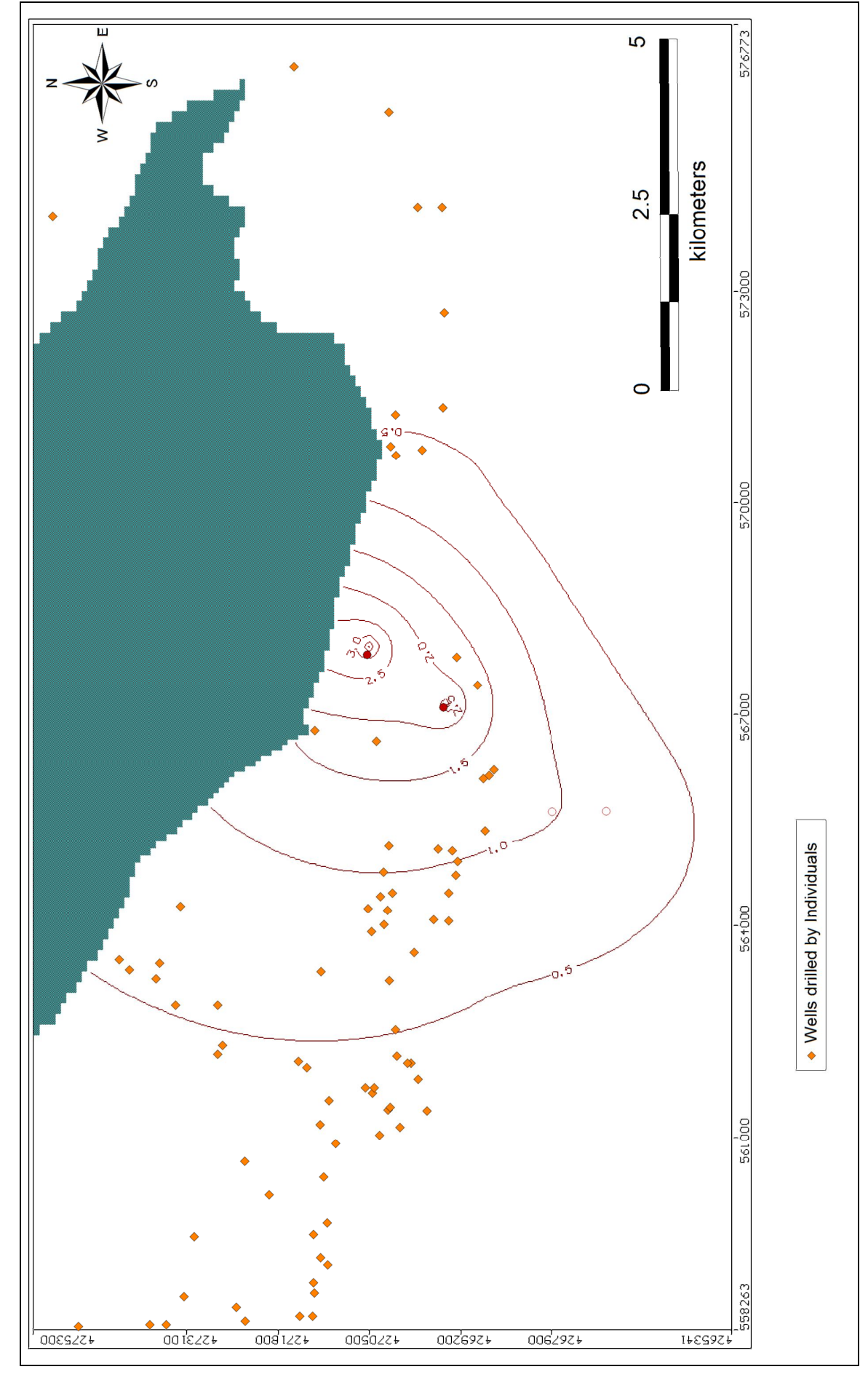

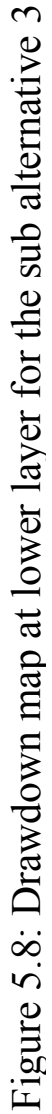


Thus, to eliminate the pumpage from the groundwater system, the alternative involving the storage of the Gediz River water was developed. For this alternative, it was assumed that a small dam with enough capacity will be constructed on the mine site to store the Gediz River water in wet seasons (October through May) and use the stored water later in the dry seasons (June through September). The total amount of water required in the mine site in dry seasons was calculated as $1,446,336 \mathrm{~m}^{3}$. The surface area of the small dam was assumed as $29,000 \mathrm{~m}^{2}$. After the calculation of the monthly evaporation amounts in each month, total water required in dry seasons was determined as $1,474,050 \mathrm{~m}^{3}$. Therefore, a small dam with a capacity of $1,600,000 \mathrm{~m}^{3}$ will be sufficient to meet the water requirement of the mine site in dry seasons. It was assumed that two pumps having $0.144 \mathrm{~m}^{3} / \mathrm{s}$ pumping rate will be used to fill the small dam. In Table 5.1, the volume of stored water, volume of water used in mine site, evaporation amounts and volume of stored water at the end of each month are summarized. The parts highlighted with blue indicate the month at which the water is released from the Demirköprü Dam. Yellow-highlighted part denotes the month at which water required for the mine site is greater than the maximum abstraction rate from the Gediz River (5\%). In conclusion, the storage of the Gediz River water is the most feasible alternative because the ecosystem of the Gediz River will not be affected and groundwater will not be used. However, the Gediz River water is highly polluted; so, it may require treatment before mine use. 


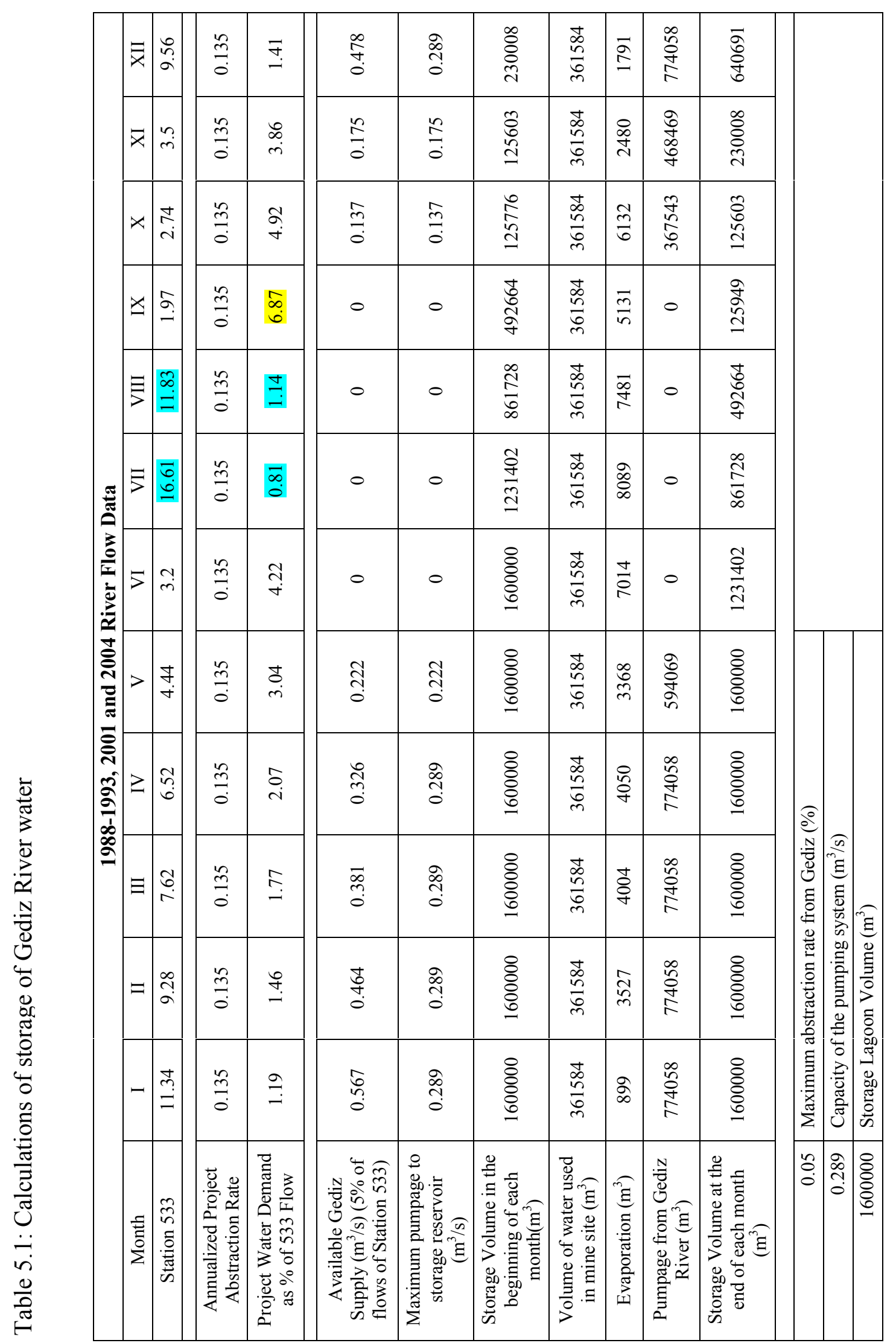


Reuse of the waste water of Turgutlu town after treatment as a final alternative explained in Chapter 4 has positive and negative sides. First of all, from environmental and hydrogeological point of views this is the best alternative because neither surface water nor groundwater will be affected by the usage of water for the mine site. Furthermore, it will provide an incentive in removing an important point source of pollution for the Gediz River. However, some technical and operational problems may be encountered for the implementation of this alternative during the 15 -years of mine life. Some of these problems could be delays in the construction of the treatment plant, the ownership for the operational costs, the process water quality requirements etc. In any case, this alternative is very appealing from the environmental, hydrogeological and social points of views and hence, its feasibility should be evaluated carefully. Alternatives, description of each alternative, pumped amount from surface water and groundwater and the evaluation of all of the alternatives are summarized in Table 5.2 


\begin{tabular}{|c|c|c|c|c|c|c|c|}
\hline & & & & & & $>$ & $>$ \\
\hline 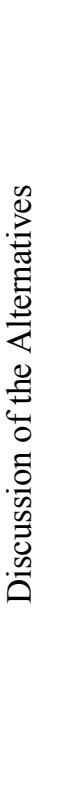 & 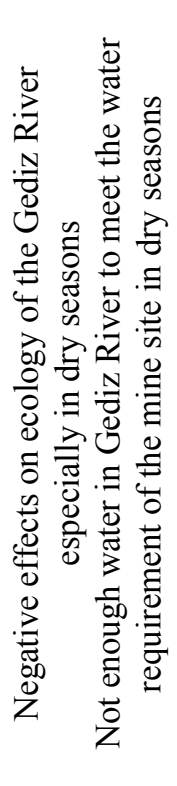 & 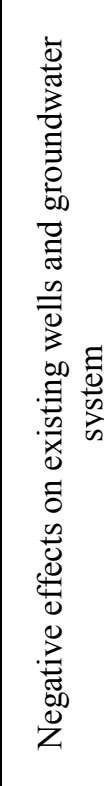 & 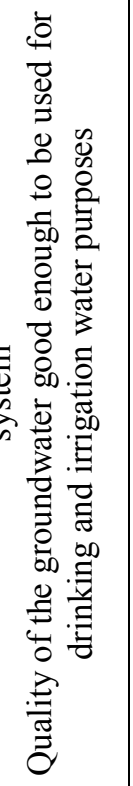 & 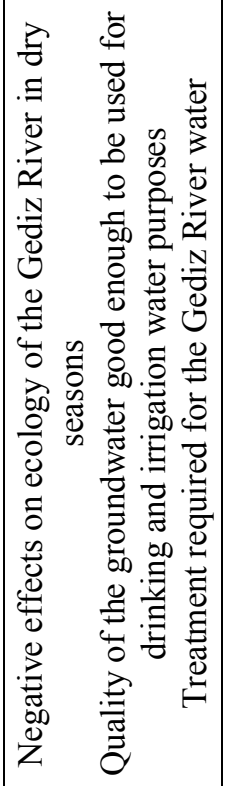 & 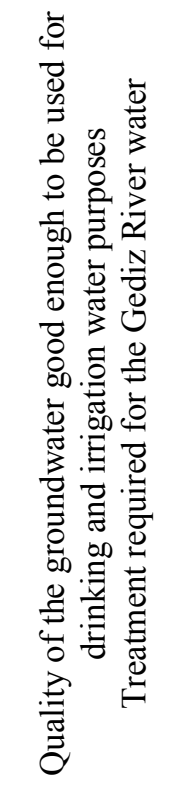 & 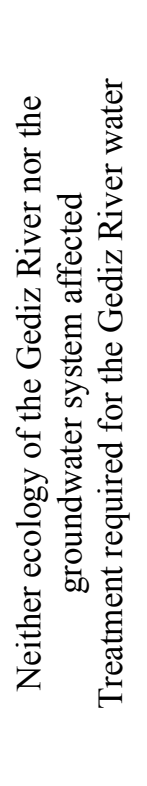 & 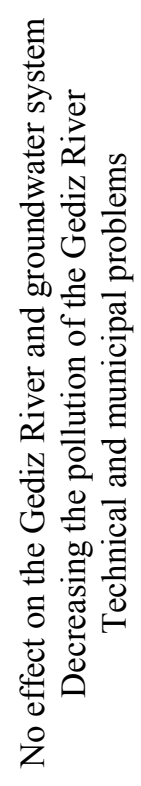 \\
\hline 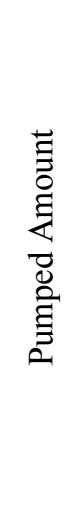 & 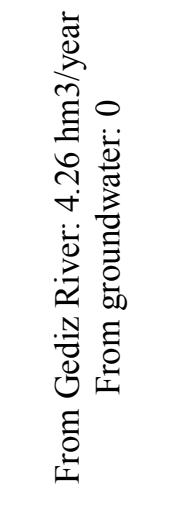 & 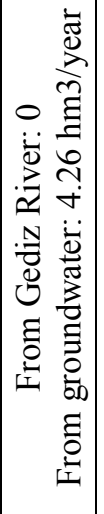 & 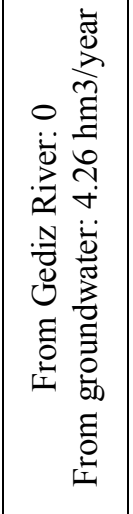 & 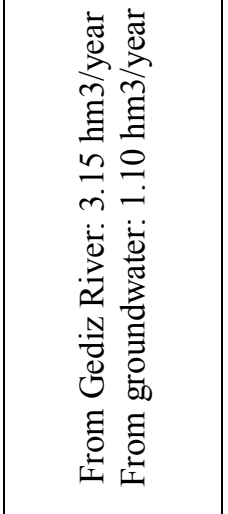 & 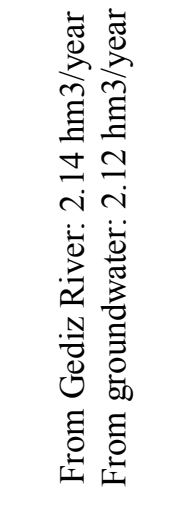 & 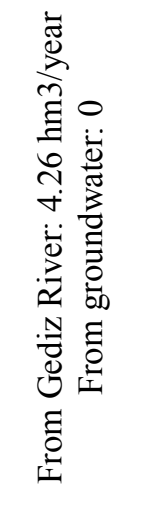 & 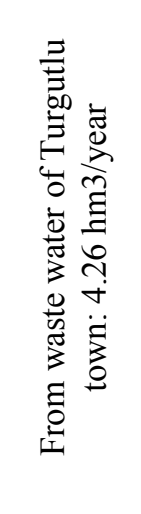 \\
\hline 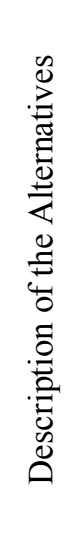 & 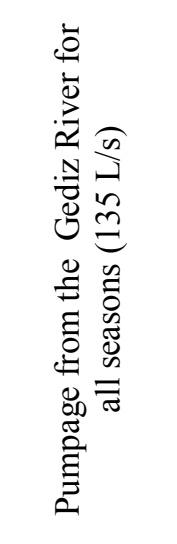 & 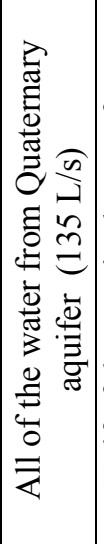 & 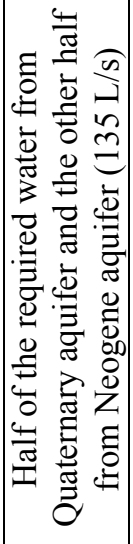 & 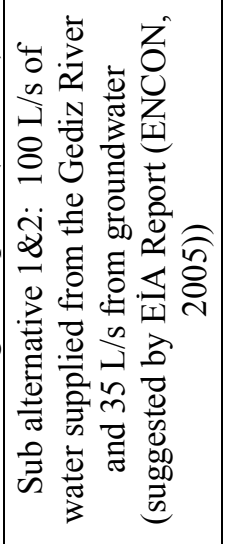 & 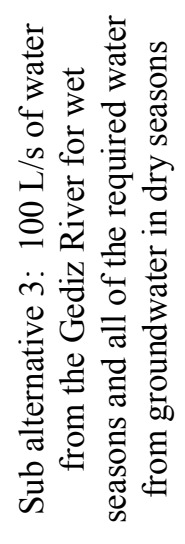 & 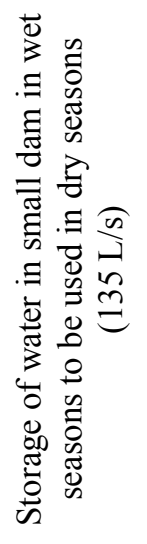 & 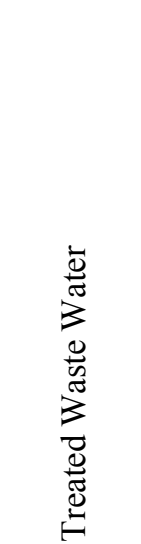 \\
\hline 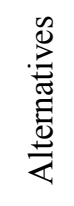 & 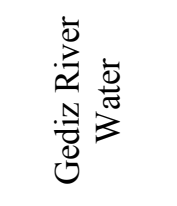 & & 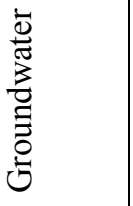 & \multicolumn{2}{|c|}{ 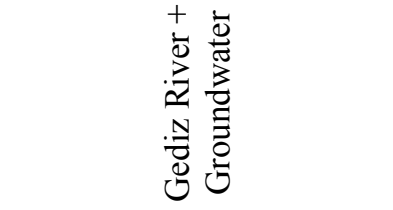 } & 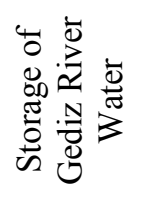 & \\
\hline
\end{tabular}




\subsection{Summary and Conclusions}

The aim of this study was to assess the impacts associated with meeting the water supply requirements for a mine site located in Turgutlu in Western Turkey. The scope of the study involved the determination of the alternative water resources, the assessment of impacts associated with each resource and the selection of the most feasible alternative.

To characterize the study area, all available data including physiography, climate and meteorology, geology, hydrology, and hydrogeology were collected and evaluated. As a result, three alternative sources of supply were considered to supply the mine process water. Surface water is the first alternative. A low flow analysis was carried out for the nearby Urganlı (No.533) station on the Gediz River to determine the volumes and the duration of the low flows. The results show that the pumpage of surface water from Gediz River alone cannot meet the water requirement of the mine site, especially in dry seasons.

The second alternative was the sole use of groundwater pumped from TurgutluSalihli aquifer. The collected data was evaluated to develop a conceptual model of the Turgutlu-Salihli aquifer. A mathematical groundwater flow model was developed in the light of conceptual model. Two of the formations, Quaternary and Neogene formations, in the study area were simulated in the mathematical model as separate layers. Selection of these formations was based on their hydrogeological properties and regional extend within the study area. The next step was the determination of the model domain and finite-difference grid. Model domain was determined according to the geological and hydrogeological characteristics of the basin. The model domain was splitted into finite difference grids having uniform hydrogeological parameters. Following the determination of model domain and finite-difference grid, input parameters, such as hydraulic and source/sink parameters were added to the model. Boundary conditions of each layer were defined in accordance with geological and hydrogeological characteristics of the system. 
Calibration of the two-layer model was the next step. The model was calibrated under pseudo steady state conditions assumed for 1991. During the calibration step, hydraulic conductivity and recharge parameters were modified by considering the field conditions. Root Mean Square Error was utilized to check the consistency between observed and calculated groundwater levels. After good match of observed and calculated groundwater levels with $9.869 \%$ root mean square error, groundwater budget for each layer was calculated. Before examining the water supply scenarios of groundwater alternative, sensitivity analysis was also performed to test the sensitivity of the model to variations in model parameters. Sensitivity analysis showed that the model was very sensitive to decrease in hydraulic conductivity and recharge from precipitation. On the other hand, it was not so sensitive to increase in these parameters.

At the end of the calibration, the model represented the groundwater levels at 1991. To get the today's groundwater levels, wells being drilled since 1992 were added to the model. Then, by assuming the today's groundwater levels as initial heads, water supply scenarios were set up. In the Scenario A, water required for the mining process was provided from the Quaternary aquifer with four pumping wells having same discharge rates. For the Scenario B, half of the water was supplied from Quaternary aquifer with two wells; the remaining was supplied from Neogene aquifer with two wells. The results of these simulations showed that pumpage from the groundwater system would impact numerous existing water supply and irrigation wells, decreasing their water levels from 1 to 7 meters. Thus, groundwater should not be considered as the sole source of water to meet the mine water requirements because its quality is good enough to be used for drinking and irrigation purposes.

According to results of surface water and groundwater alternatives, some sub alternatives were also developed at which the surface water and the groundwater were used in various proportions. The sub alternative 1 and 2 were the simulation of scenarios mentioned in the EIA report of the ENCON (2005). It was assumed that $100 \mathrm{~L} / \mathrm{s}$ of the water was supplied from Gediz River and the rest was pumped from 
the groundwater with two different well designs. These sub alternatives are not so feasible because of smaller reliability of obtaining river water without impacting the ecosystems in the Gediz River. Therefore, in dry seasons, the source of water should be the combination of groundwater and the stored Gediz River water. Sub alternative 3 was developed at which in wet seasons $100 \mathrm{~L} / \mathrm{s}$ of the required water was supplied from the Gediz River and the rest was pumped from the groundwater. In dry seasons groundwater was the only source of water. To minimize the effects on groundwater, another alternative involving the storage of the Gediz River water was developed. A small dam having enough capacity to store the required water for the mine site in dry seasons was proposed. The dam is kept full at the beginning of the dry season by the Gediz river water and was used in supplying the required mine water during the dry season without using neither river water nor groundwater. This is the most feasible alternative because there is not any negative effect on both the ecology of the Gediz River and groundwater, but Gediz River water may need treatment because it is highly polluted.

The use of the waste water of Turgutlu town after treatment was the third alternative. For this alternative, the amount of waste water produced in Turgutlu town was calculated. It was observed that the quantity of the waste water would meet the water requirement of the mine site. From the environmental point of view, this is the best alternative because it will provide a basis for eliminating the point source contamination of the Gediz River and will not affect the riparian water rights. However, the operational problems that may take place during the life of the mine seem to be the negative side of this alternative.

In conclusion, the assessment of water supply impacts for a mine site in Turgutlu in Western Turkey was carried out in this study. Results of the alternatives show that each alternative is applicable to supply the required water to the mine site. However, the storage of the Gediz River water in a small dam in wet seasons to be used later in dry seasons and the reuse of waste water of Turgutlu after treatment are the alternatives with least impacts on existing water users and related ecosystems. 


\section{REFERENCES}

Bozkurt, E., and Satır, M., 2000, The southern Menderes Massif (Western Turkey): Geochronology and Exhumation History, Geological Journal, 35, 285-296.

Bozkurt, E., and Sözbilir, H., 2004, Tectonic Evolution of the Gediz Graben: Field Evidence for an Episodic, Two-Stage Extension in Western Turkey, Geological Magazine, 141(ii), 63-79.

Çiftçi, N. B., and Bozkurt, E., 2009, Evolution of the Miocene Sedimentary Fill of the Gediz Graben, SW Turkey. Sedimentary Geology, 216, 49-79.

DSİ, 1972, Geophysical Resistivity Investigation of Gediz Plain (Manisa - Salihli Turgutlu), General Directorate of State Hydraulics Works, İzmir.

DSİ, 1983, The Hydrogeological Investigation Report for Gediz River Basin (Sarıgöl-Alaşehir, Salihli-Turgutlu and Akhisar-Manisa Plains), General Directorate of State Hydraulis Works - $2^{\text {nd }}$ District Office, İzmir.

ENCON, 2005, Environmental Impact Assessment Report-Çaldağ Project, Submitted to Ministry of Environment, Ankara.

Harbaugh, A. W., Banta, E. R., Hill, M. C., and McDonald, M. G., 2000, MODFLOW-2000, the U.S. Geological Survey Modular Ground-Water Model: User Guide to Modularization Concepts and the Ground-Water Flow Process, U.S. Geological Survey, Open-File Report 00-92. 
Man-ar Construction and Environmental Technologies Company, 2009, Feasibility Report of Turgutlu Waste Water Treatment Plant Submitted to Turgutlu Municipality, Manisa.

Ministry of Environment and Forestry, 2006, Urban Wastewater Treatment Directive, Ankara.

MTA, 1995, Survey and Drilling Results of Geothermal Energy Research Report of Gediz Plain (Manisa-Turgutlu-Salihli-Alaşehir), Report No: 990, İzmir.

Philippson, A., 1915, Reisin Und Forsehungen in Westliehen Klainasien: Pet. Mitt. Erg. M. 167, 173, 177, 1980, Cotha

Pyrce, R., 2004, Hydrological Low Flow Indices and their Uses, Watershed Science Center, WSC Report No. 04-2004, 33p.

Salas, J.D., 1980, Analysis of Mean Flows and Low Flows, in Hydrology for Transportation Engineers, U.S. Department of Transportation Publication No. FHWA-IP-80-I, pp: 461-513.

Selim, H. H., \& Yanık, G., 2009, Development of the Cambazlı ( Turgutlu / MANISA ) Fissure-ridge-type Travertine and Relationship with Active Tectonics, Gediz Graben, Turkey, Quaternary International, 199, 157-163.

Smakhtin, V. U., 2001, Low Flow Hydrology: a Review. Journal of Hydrology, 240, 147-186.

Thornthwaite, C., W., 1948, An Approach towards a Rational Classification of Climate, Geography Review, Volume: 38, No. 1, pages 55-94. 
Typsa Consulting Engineers and Architects, 2007, Feasibility Report of the Comprehensive Environmental Master Plan of the Gediz River Basin Project, Turkey.

Yazıcıgil, H., 2008, Hydrogeological Characterization of Çaldağ Nickel Mine Project Area, Sardes Nikel Madencilik A.Ş.

Yazıcıgil, H., Doyuran, V., Karahanoğlu, N.,Yanmaz, M., Çamur, Z., Toprak, V., Rojay, B., Yılmaz K.K., Şakıyan, J., Süzen, L., Yeşilnacar, E., Gündoğdu, A., Pusatl1, T., and Tuzcu, B., 2000. Investigation and Management of Groundwater Resources in Küçük Menderes River Basin under the scope of Revised Hydrogeological Studies, Final Report: Vol. I: Main Report, Vol. II: Meteorology and Hydrology, Vol. III: Geology, Vol. IV: Groundwater Database, Vol. V: Hydrogeology, Vol. VI: Groundwater Chemistry, Quality and Contamination, Vol. VII: Groundwater Flow Model Project, Project no: 98-03-09-01-01. Middle East Technical University, Ankara. 